\author{
UNIVERSIDADE DE SÃO PAULO \\ FACULDADE DE FILOSOFIA, LETRAS E CIÊNCIAS HUMANAS \\ DEPARTAMENTO DE CIÊNCIA POLÍTICA \\ PROGRAMA DE PÓS-GRADUAÇÃO EM CIÊNCIA POLÍTICA
}

\title{
POLÍTICA DE SEGURANÇA PÚBLICA NO BRASIL \\ NA PÓS-TRANSIÇÃO DEMOCRÁTICA: \\ DESLOCAMENTOS EM UM MODELO RESISTENTE
}

Ligia Maria Daher Gonçalves

Dissertação apresentada ao Programa de PósGraduação em Ciência Política, do Departamento de Ciência Política da Faculdade de Letras, Filosofia e Ciências Humanas da Universidade de São Paulo, para obtenção do título de Mestre em Ciência Política.

(Versão revisada)

Orientador: Prof. Dr. Adrian Gurza Lavalle

São Paulo 


$$
\text { UNIVERSIDADE DE SÃO PAULO }
$$

FACULDADE DE FILOSOFIA, LETRAS E CIÊNCIAS HUMANAS DEPARTAMENTO DE CIÊNCIA POLÍTICA PROGRAMA DE PÓS-GRADUAÇÃO EM CIÊNCIA POLÍTICA

\section{POLÍTICA DE SEGURANÇA PÚBLICA NO BRASIL NA PÓS-TRANSIÇÃO DEMOCRÁTICA: DESLOCAMENTOS EM UM MODELO RESISTENTE}

Ligia Maria Daher Gonçalves

São Paulo 2009 
Para meu filho Ricardo,

por tornar tudo pleno de sentido.

Para meus pais,

Janette (in memorian) e Luiz. 


\section{Agradecimentos}

Um dos momentos mais preciosos ao se concluir um processo que exigiu grande esforço é aquele em que temos a possibilidade de manifestar nossa gratidão pela vida e pelas pessoas. Esta pesquisa de mestrado, que se desenvolveu com muito desejo, em meio a outras demandas da vida, me dá agora a oportunidade de expressar meu enorme agradecimento e reconhecimento:

Ao Rico, meu filho, fonte maior de inspiração, por ser a pessoa bacana, atenta e sensível que é. Obrigada pela paciência, pela torcida, pelas palavras simples e sensatas e pelos sorrisos marotos que me animaram e me fortaleceram tantas vezes. Obrigada pela alegria de cada momento que dividimos.

Ao meu pai, Luiz, pelo exemplo de força de vontade, por seu apoio constante, pelos conselhos nos momentos em que eu precisava ouvi-los e pelo rigor com que sempre tratou as palavras, fazendo-me mais atenta a elas.

À minha mãe, Janette, sempre tão presente no meu coração e nos meus pensamentos, por seus ensinamentos e por todos os seus gestos amorosos e encorajadores, que continuam me estimulando a seguir em frente.

À Andréa Rodrigues Pinto, por partilhar comigo há quase 40 anos todos os momentos importantes da minha vida. Por acreditar em mim e no meu trabalho e pelas infinitas vezes em que me ouviu com amor e paciência, sem nunca me deixar entregar os pontos. Minha gratidão pelos laços fraternos que nos unem.

À minha irmã Lilian, pelos bons momentos compartilhados juntamente com Araken, Gui, Xan e Gabi e pelo prazer do convívio cotidiano com os meninos nos últimos anos.

À Cristina Kfouri, Eduardo, Fabinho e Laurinha, pela disponibilidade e pelo carinho que, indiferente a mudanças de rumo, permaneceu entre nós.

Aos amigos de todas as horas: Maruzania Soares, Izabela Tamaso, Cecília Barão Alegretti, Tercio Redondo, Claudia Botão, Ana Claudia Paulo e Ana Lucia Pastore, pelo forte sentimento de bem-querer que nos une há tantos anos.

À Izabela, agradeço, ainda, por ter me estimulado a iniciar este percurso, pelos incentivos que se seguiram e por ter, com sua maior experiência acadêmica, lançado luzes em momentos de impasse. 
Agradeço também à Cecília pela versão do resumo para o inglês e ao Tercio pela revisão final da dissertação. A ambos, meu reconhecimento pelo trabalho cuidadoso que fizeram em meio a tantos outros afazeres.

Aos amigos Juliana Delfino, Renata Ártico, Fátima Dagostino e Pedro Aguerre, pela ajuda, de diferentes maneiras, em etapas distintas deste processo.

Aos meus companheiros de consultoria no PNUD/Ministério da Justiça, pela agradável convivência durante o ano de 2008.

Ao Prof. Vicente Trevas, por ter estimulado minha reflexão em várias oportunidades e por ter chamado minha atenção para importantes aspectos federativos que envolvem a política de segurança pública e que foram determinantes para a reconstrução de meu objeto de pesquisa.

À Prof ${ }^{a}$. Marta Arretche e ao Prof. Rogério Arantes pelas observações feitas no meu exame de qualificação, contribuindo para a correção de rumos e para que eu pudesse delinear melhor meu objeto.

A pesquisa em nada avançaria sem as pessoas e instituições que se dispuseram a colaborar. Agradeço enormemente a todos aqueles que disponibilizaram textos e informações, que me concederam entrevistas e que responderam ao questionário.

Muitos foram os aprendizados nessa longa e inacabada jornada de direitos humanos e de segurança pública. Agradeço a todos os profissionais que conheci e aos amigos que fiz nesta trajetória.

Aos funcionários do Departamento de Ciência Política, em especial à Vivian, sempre disposta a orientar sobre os trâmites burocráticos do mestrado.

Ao meu orientador, Adrian Gurza Lavalle, agradeço por ter aceitado me orientar já no curso do processo e pelo olhar rigoroso e exigente, tão desesperador quanto estimulante, que me fez repensar e reescrever muitas vezes.

Por fim, um agradecimento especial a Benedito Domingos Mariano, pelo inestimável apoio. Por ter possibilitado que eu conciliasse atividades acadêmicas e profissionais no início deste percurso, pelas observações feitas quando da leitura da última versão deste trabalho e por ter facilitado meu acesso aos membros da Coordenação Nacional da 1‥ CONSEG. Obrigada pela confiança profissional em mim depositada e pelas discussões sobre o tema ao longo de vários anos. 


\section{Resumo}

A presente dissertação analisa as mudanças implementadas na agenda da segurança pública na pós-transição democrática e os motivos pelos quais o modelo de segurança pública no Brasil é tão resistente a reformas. O cenário democrático testemunhou a entrada de novos atores na comunidade da política, e, a partir de então, novas e velhas visões acerca do tema passaram a coexistir. Apesar da crise da segurança pública, explicitada nas décadas de 1980-1990, nenhuma das propostas de reforma estrutural do modelo da política obteve êxito até o momento, o que pode ser explicado pela ausência de uma ampla coalizão em torno de uma agenda mínima de reformas e pelo padrão de dependência da trajetória da política. As mudanças possíveis nesse contexto, embora sejam insuficientes para conformar um novo modelo de política, têm provocado deslocamentos em algumas das características históricas do sistema de segurança pública, promovendo pequenas alterações na sua dinâmica federativa.

Palavras-chave: política de segurança pública; reforma da política de segurança; neoinstitucionalismo histórico; federalismo; comunidade da política. 


\begin{abstract}
This dissertation analyzes the changes to the agenda of public security in Brazil after its democratic transition. It also addresses the reasons why the Brazilian policy model of public security might be so resistant to reforms. The new democratic scenario witnessed new actors entering the policy community and brought together old and new views on the subject. In spite of the crisis in the public security, which was brought to light in the 1980's and 1990's, none of the proposals for structural reform of the policy model have hitherto been successful. Such a failure might be explained by the absence of a broad coalition around a minimum agenda of reforms and also by the path dependence of the public security policy. The possible changes in this context, despite being insufficient to forge a new policy model, have led to shifts in some of the historical features of the system of public security, promoting small changes in its federative dynamics.
\end{abstract}

Keywords: public security policy; public security policy reform; historical neoinstitucionalism; federalism; policy community. 


\section{Lista de abreviaturas e siglas}

$A B C$ - Associação Brasileira de Criminalística

ADEPOL- Associação dos Delegados de Polícia do Brasil

ADPF - Associação Nacional dos Delegados de Polícia Federal

AMEBRASIL - Associação Nacional dos Oficiais Militares Estaduais

ANASPRA - Associação Nacional de Entidades Representativas de Praças Policiais

e Bombeiros

CAF - Comitê de Articulação Federativa

CF - Constituição Federal

CeSEC - Centro de Estudos de Segurança e Cidadania

CISMEL - Consórcio de Segurança Pública e Cidadania de Londrina e Região Metropolitana

COBRAPOL - Confederação Brasileira de Trabalhadores Policiais Civis

CRISP - Centro de Estudos de Criminalidade e Segurança Pública

CON - Coordenação Nacional Executiva da 1ª. CONSEG

CONASP - Conselho Nacional de Segurança Pública

CNCG - Conselho Nacional dos Comandantes Gerais das Polícias Militares e dos

Corpos de Bombeiros Militares

CNGM - Conselho Nacional das Guardas Municipais

CONSEG - Conferência Nacional de Segurança Pública

CONSESP - Conselho Nacional dos Secretários Estaduais de Segurança Pública

DPF - Departamento de Polícia Federal

EAD - Ensino à distância

FBSP - Fórum Brasileiro de Segurança Pública

FENAPEF - Federação Nacional dos Policiais Federais

FENAPRF - Federação Nacional dos Policiais Rodoviários Federais

FENDH - Fórum de Entidades Nacionais de Direitos Humanos

FENEME - Federação Nacional de Entidades de Oficiais Militares Estaduais

FHC - Fernando Henrique Cardoso

FNS - Força Nacional de Segurança

FNOP - Fórum Nacional de Ouvidores de Polícia 
FNP - Frente Nacional de Prefeitos

FNSP - Fundo Nacional de Segurança Pública

FUNDEB - Fundo de Manutenção e Desenvolvimento da Educação Básica e de Valorização dos Profissionais da Educação

GAJOP - Gabinete de Assessoria Jurídica às Organizações Populares

GCM - Guarda Civil Municipal

GGI-E - Gabinete de Gestão Integrada Estadual

GGI-M - Gabinete de Gestão Integrada Municipal

GOE - Grupo de Operações Especiais

IBGE - Instituto Brasileiro de Geografia e Estatística

IGPM - Inspetoria Geral das Polícias Militares

ILANUD - Instituto Latino-Americano das Nações Unidas para Prevenção do Delito e

Tratamento do Delinquente

INFOCRIM - Sistema de Informações Criminais do Estado de São Paulo

INFOSEG - Rede Nacional de Informações de Segurança Pública, Justiça e Fiscalização

IP - Inquérito policial

IPM - Inquérito Policial Militar

IPEA - Instituto de Pesquisa Econômica Aplicada

ISPCV - Instituto São Paulo Contra a Violência

MJ - Ministério da Justiça

MP - Ministério Público

NEV - Núcleo de Estudos da Violência

OEI - Organização dos Estados Ibero-americanos

ONU - Organização das Nações Unidas

PC - Polícia Civil

PCC - Primeiro Comando da Capital

PEC - Projeto de Emenda Constitucional

PF - Polícia Federal

PIAPS - Plano de Integração e Acompanhamento dos Programas Sociais de Prevenção da Violência

PM - Polícia Militar 
PNAGE - Programa Nacional de Apoio à Modernização da Gestão e do Planejamento dos Estados e do Distrito Federal

PNDH - Programa Nacional de Direitos Humanos

PNSP - Plano Nacional de Segurança Pública

PRONASCI - Programa Nacional de Segurança Pública com Cidadania

PROVITA - Programa Estadual de Proteção a Testemunha

RENAESP - Rede Nacional de Altos Estudos em Segurança Pública

SEDH - Secretaria Especial de Direitos Humanos

SENASP - Secretaria Nacional de Segurança Pública

SEPLANSEG - Secretaria de Planejamento de Ações Nacionais de Segurança Pública

SIMAP - Sistema de Monitoramento, Avaliação e Desenvolvimento Institucional do Pronasci

SINARM - Sistema Nacional de Armas

SINDAPEF - Sindicato dos Agentes Penitenciários Federais

SINESPJC - Sistema Nacional de Estatísticas de Segurança Pública e Justiça

Criminal

SUS - Sistema Único de Saúde

SUSP - Sistema Único de Segurança Pública

SSP - Secretaria de Segurança Pública

TCO - Termos Circunstanciados de Ocorrência 


\section{Sumário}

Introdução 1

Capítulo 1 - Federalismo, políticas públicas e a perspectiva da análise institucional 5

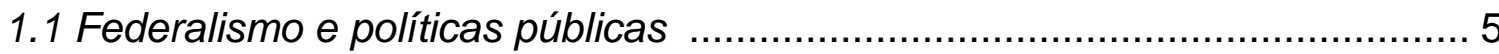

1.2 Perspectiva institucional: considerando instituições, processos e atores ...... 11

Capítulo 2 - Política de segurança pública brasileira: características e panorama histórico ...................................................................... 13

2.1 Caracterização histórica do modelo de segurança pública brasileiro ............ 15 2.2 Segurança pública no processo constituinte e o desenho da política de segurança pública na Carta de 1988 18

2.3 Arranjo institucional do sistema de segurança pública e alguns problemas dele decorrentes 23

Capítulo 3 - Crise da segurança pública: rupturas e esgotamento do modelo

Capítulo 4 - Comunidade da política de segurança pública: atores e preferências 32

4.1 Diferentes paradigmas da segurança pública ............................................ 32

4.2 Comunidade da política: novos e velhos atores ....................................... 35

4.3 Pesquisando preferências e propostas reformistas .................................... 42

4.4 Preferências reformistas à luz da literatura e de fontes documentais ........... 65 4.5 Resistência do atual modelo de segurança pública, face às propostas de reformas estruturais 69

Capítulo 5 - Mudanças possíveis: pequenos deslocamentos nas características da política 75

5.1 Experiência inovadora dos municípios 76 
5.1.1 Contextualizando as estratégias locais de prevenção do crime 76

5.1.2 Novos atores, novas agendas: os municípios e a prevenção no Brasil 79 5.2 Governo FHC: marco inaugural da inclusão da política de segurança pública na agenda federal 86

5.2.1 Agenda, contexto e a criação da Secretaria Nacional de Segurança Pública 86

5.2.2 Plano Nacional de Segurança Pública - PNSP 92

5.2.3. Criação do Fundo Nacional de Segurança Pública 94

5.3 Governo Lula: abandono da agenda de reformas radicais e tentativa de articular uma política nacional de segurança pública 96

5.3.1 Promessas do Plano de Segurança Pública e recuo na proposição das reformas radicais 98

5.3.2 Sistema Único de Segurança Pública - SUSP 100

5.3.3 Fundo Nacional de Segurança Pública: alteração legislativa e novos critérios para a distribuição de recursos 104

5.3.4 Força Nacional: nova força policial, sem novos policiais 109

5.3.5 Programa Nacional de Segurança Pública com Cidadania - Pronasci 111

5.3.6 Conferência Nacional de Segurança Pública 122

Conclusão 128

Referências bibliográficas 134

Anexo A - Relação dos integrantes da CON 150

Anexo B - Matriz do questionário 153

Anexo C - Sistematização das respostas ao questionário 155

Anexo D - Quadro dos municípios que aderiram ao Pronasci 174

Anexo E - Princípios e Diretrizes da 1 1 a CONSEG 176 


\section{Introdução}

A presente dissertação tem por objeto de estudo a política de segurança pública no Brasil na pós-transição democrática, em três momentos: o processo constituinte de 1987-1988, o Governo FHC, o Governo Lula. Seu objetivo consiste em analisar, considerando instituições e atores relevantes, as continuidades no padrão da política de segurança pública, bem como as mudanças que foram possíveis nesse campo.

A democratização e o processo constituinte de 1987-1988 possibilitaram reformas no desenho de várias políticas públicas no Brasil e propiciaram maior participação da sociedade civil. Essas reformas, no entanto, não atingiram a política de segurança pública, que manteve no novo texto constitucional suas principais características históricas. Decorridos mais de 30 anos do início do processo de transição democrática, o sistema de justiça criminal foi o setor que menos progressos fez em relação à modernização e à democratização de suas instituições, em especial das instituições policiais (RAMOS, 2007). Desde então, as mudanças na área da segurança pública têm sido vagarosas, localizadas e incrementais, não conformando um quadro de reformas estruturais da política. Nas décadas de 1980 e 1990, as estatísticas criminais elevaram-se expressivamente e a discussão sobre segurança pública caiu no domínio público, alvo da mídia e da crítica de novos atores sociais e políticos que começaram a pautar o tema em suas agendas. Analiso, nos períodos estudados, como se estruturou a formação da agenda da segurança pública brasileira, bem como quais foram os deslocamentos ocorridos no desenho tradicional da política.

Inicio pela descrição das características do sistema de segurança pública ${ }^{1}$ que se mostram persistentes ao longo da história, descrição que auxiliará a balizar mudanças na política. Em seguida, analiso o tratamento dado à política de segurança pública no processo constituinte que resultou na Constituição Federal de 1988 e de que forma as instituições condicionaram as estratégias e as preferências

\footnotetext{
${ }^{1}$ O sistema de justiça criminal é composto pelo sistema de segurança pública, pelo poder judiciário e pelo sistema penitenciário. Embora, as instituições de segurança pública devam ser consideradas de maneira articulada com os outros dois campos de instituições do sistema de justiça criminal, para o exame da evolução e do enfrentamento do crime e da violência, o foco do presente estudo são as instituições e as políticas de segurança pública, estritamente.
} 
dos atores. Abordo os motivos pelos quais a política de segurança pública continuou, no que diz respeito à estrutura das instituições policiais, basicamente com o mesmo desenho da Constituição autoritária de 1967-1969.

Analiso alguns conflitos decorrentes do arranjo institucional do modelo tradicional da política e como o aumento crescente dos índices de violência no Brasil, no período pós-transição democrática, expôs o esgotamento desse modelo. Num contexto de criminalidade crescente, cada vez mais os governos federal e municipais foram sendo chamados a oferecer respostas. Criaram-se centros de pesquisa para estudar o assunto e formular propostas e a sociedade civil começou a se reorganizar em torno do tema. Novos atores ampliaram a comunidade da política, que começou a pautar diferentes soluções e a defender diferentes paradigmas para a segurança pública brasileira. Parte dos atores da comunidade da política de segurança pública demanda o reforço do poder do aparato repressivo do Estado, com o incremento dos recursos materiais e humanos, e com modernização gerencial; alguns atores enfatizam a importância de políticas públicas preventivas para um adequado provimento de segurança; outros propõem reformas radicais para a política, especialmente para as instituições policiais, embora também não haja consenso, entre os atores com preferências reformistas radicais, sobre o novo modelo desejado.

Analiso os motivos pelos quais nenhuma das proposituras de reformas radicais, que implicariam uma ruptura com o modelo tradicional, foi exitosa até o momento. Um dos fatores que ajudam a explicar a resiliência do modelo da política de segurança pública a reformas radicais refere-se ao padrão de dependência da trajetória da política (path dependence), isto é, aos altos custos de reversão do modelo decorrentes de escolhas institucionais passadas. Além disso, a multiplicidade de atores com diferentes e polarizadas posições dificulta a construção de uma coalizão ampla capaz de dar sustentação a um processo substancial de reformas.

Constatada a resistência do modelo tradicional da política de segurança pública a reformas estruturais, investigo quais são e a que se devem as inovações na política identificando conjunturas críticas e janelas de oportunidade que ensejaram mudanças, ainda que apenas incrementais, no setor. Nesse sentido, analiso a entrada do município como novo ator relevante na política de segurança 
pública e como inovações implementadas por alguns municípios brasileiros influenciaram a agenda do governo federal quando da formulação de novos programas. Abordo o tratamento da política de segurança no Governo FHC, ora valendo-se de conjunturas críticas para implementar sua agenda ora reformulando suas estratégias para fazer frente a essas conjunturas.

Pesquisando o Governo Lula, analiso a agenda programática inicial de reformas radicais da política e os motivos pelos quais tal agenda logo foi abandonada. Analiso as mudanças incrementais implementadas, abordando ações e programas que procuram induzir maior participação e cooperação intergovernamental em torno da política de segurança pública.

A pesquisa mostra que ocorreu uma reconfiguração do campo, com o ingresso de novos atores na comunidade da política. Para além de muitas contradições, polarizações e interesses manifestamente corporativos, essa comunidade começa a apresentar algumas confluências no que diz respeito, por exemplo, à importância da participação social e do papel preventivo dos municípios na política de segurança pública e - de forma menos ampla, mas não por isso menos significativa - à desvinculação das polícias militares do Exército. As mudanças no campo e as reformas incrementais promoveram pequenas alterações em algumas características tradicionais da política e pequenos deslocamentos na dinâmica federativa na matéria, embora os principais aspectos da política, como sua centralização nas instituições policiais estaduais e o modelo dessas instituições, sigam inalterados.

Ao analisar a política de segurança pública à luz do federalismo, explicito alguns efeitos institucionais decorrentes de seus arranjos. Pierson (1995), ressaltando que o federalismo não é apenas um modelo de implicações isoladas, relaciona três desses efeitos, claramente identificáveis com a natureza dos deslocamentos que estão sendo produzidos na política de segurança pública: 1) mudanças nas preferências políticas, estratégias e influência dos atores sociais; 2) a emergência de novos atores significativos; 3) dilemas predizíveis conectados à divisão da autoridade decisória entre múltiplas jurisdições.

A pesquisa se desenvolveu por meio da análise da bibliografia disponível sobre o tema e de documentos institucionais. Realizei algumas entrevistas com gestores do Ministério da Justiça para recolher informações e dados sobre os 
programas implementados. Procurando compor um diagnóstico atualizado do campo e a fim de evitar atribuir aos atores da comunidade da política as mesmas preferências com as quais eles são usualmente identificados, apliquei um questionário a representantes de entidades nacionais que congregam trabalhadores e gestores da segurança pública e de entidades da sociedade civil atuantes no setor. Para ter acesso a atores tão representativos da comunidade da política, aproveitei a ocasião da primeira Conferência Nacional de Segurança Pública - CONSEG, cujos resultados, também estudados neste trabalho, acabaram por ratificar algumas percepções analíticas.

Procurei, na medida do possível, controlar meus juízos normativos e empreender, a partir do campo empírico, um estudo teórico-analítico de meu objeto, utilizando conceitos da teoria institucional, em especial do neoinstitucionalismo histórico, e da teoria sobre federalismo.

Tanto a academia como especialistas têm produzido trabalhos importantes e ricos do ponto de vista da compreensão da política de segurança pública, mas, ao final desta dissertação, espero ter contribuído para o debate com algumas constatações empíricas e com um enquadramento específico no plano da análise teórico-conceitual. 


\section{Capítulo 1 - Federalismo, políticas públicas e a perspectiva da análise institucional}

Este capítulo tem por objetivo contextualizar as duas principais referências analíticas utilizadas nesta dissertação: de um lado, o federalismo e suas implicações sobre as políticas públicas e, de outro, no campo da análise institucional, aspectos conceituais do neoinstitucionalismo histórico.

\subsection{Federalismo e políticas públicas}

O estudo das políticas públicas demanda a compreensão não apenas das preferências sobre quem deve obter o quê, mas também sobre as estratégias para a efetivação dessas preferências, o nível de governo que deve se encarregar da formulação e da implementação da política, a definição de quem tem autonomia decisória, quem arca com os custos, quais as fontes de recursos e como se dá a coordenação e a cooperação entre os entes federados na implementação dessas políticas. Esta seção tem por objetivo apresentar, de forma geral, as principais tendências do federalismo brasileiro consagradas a partir da Constituição Federal de 1988 a fim de se compreender, em seguida, tanto as especificidades da política de segurança pública nesse contexto, como as posteriores alterações em sua dinâmica federativa e os constrangimentos e incentivos que a conformam.

Nos anos 1980, a agenda da redemocratização orientava-se pela bandeira da descentralização. Negativamente marcados pelo longo período de centralização autoritária do regime militar instituído em 1964, os constituintes e a sociedade associavam descentralização à democratização ${ }^{2}$ (MELO, 2005). Contudo, apesar do grande consenso existente entre atores políticos e sociais em torno dessa ideia-

\footnotetext{
${ }^{2}$ Utilizando um conceito analítico do neoinstitucionalismo histórico, pode-se dizer que a inspiração descentralizadora que marcou as preferências dos constituintes em relação a várias políticas sociais expressa um mecanismo de police feedback negativo, referido à associação entre a alta centralização das políticas públicas e o período autoritário militar. Segundo esse referencial teórico, denomina-se de police feedback o efeito que as políticas anteriores têm sobre a formação das preferências no momento presente (PIERSON, 2004).
} 
força, o andamento da descentralização não se deu de forma linear, mas de forma altamente complexa e marcada por tendências contraditórias (ALMEIDA, 2005).

Apesar do desenho constitucional brasileiro, no que tange à distribuição de competências, denotar um federalismo de caráter cooperativo, vários autores (ABRUCIO, 2005; SOUZA, 2005) chamam a atenção para seu caráter, na prática, bastante competitivo, seja em razão da desigualdade técnica, de recursos e de gestão entre as unidades subnacionais, seja pela inexistência de dispositivos institucionais que estimulem e regulem a cooperação. Tanto a persistência das desigualdades regionais como a insuficiência de dispositivos de cooperação intergovernamental capazes de aumentar a eficácia e a eficiência das políticas públicas continuam sendo, para esses autores, grandes desafios do federalismo brasileiro.

De fato, a persistência de desigualdades fica explicitada, por exemplo, quando se analisam os municípios. Estes foram, de maneira inédita na história federativa brasileira, elevados à condição de entes federados autônomos pela Constituição Federal de 1988. Se, por um lado, essa inovação deu ensejo à emergência de novos atores com capacidade de incidir na formulação e na gestão de políticas públicas, por outro, a efetivação prática da autonomia municipal ainda é bastante desigual em todo o país. As desigualdades de condições administrativas e econômicas entre os municípios são significativas. Segundo dados do IBGE, apresentados na tabela abaixo, dos 5.564 municípios brasileiros existentes em 2006, 4.986 deles (quase $90 \%$ ) tinham até 50.000 habitantes e eram, em sua maioria, fortemente dependentes de transferências governamentais. Em 2003, por exemplo, enquanto a União foi responsável por $67,9 \%$ de toda a arrecadação de tributos e os estados por $27 \%$, os municípios foram responsáveis por apenas $5,1 \%$. No mesmo período, os municípios, com as transferências governamentais, passaram a responder por cerca de 19\% da receita nacional disponível (IBGE, 2007). 


\begin{tabular}{|c|c|}
\hline $\begin{array}{c}\text { Classes de tamanho da } \\
\text { população dos } \\
\text { municípios brasileiros }\end{array}$ & $\begin{array}{c}\text { Número de } \\
\text { municípios }\end{array}$ \\
\hline Até 5.000 & 1.371 \\
\hline De 5.001 a 10.000 & 1.290 \\
\hline De 10.001 a 20.000 & 1.292 \\
\hline De 20.001 a 50.000 & 1.033 \\
\hline De 50.001 a 100.000 & 311 \\
\hline De 100.001 a 500.000 & 231 \\
\hline Mais de 500.000 & 36 \\
\hline Total & 5.564 \\
\hline
\end{tabular}

Fonte: IBGE, Pesquisa de Informações Básicas Municipais, 2007.

De maneira geral, o arranjo federativo desenhado pela Constituição Federal de 1988 beneficiou estados e municípios, com maior descentralização de recursos. Nos anos posteriores à promulgação da Constituição, no entanto, o federalismo fiscal foi sofrendo ajustes não apenas para compensar desigualdades horizontais na capacidade de arrecadação, como também em razão da pressão por austeridade fiscal exigida pelo contexto macroeconômico e pela necessidade de estabilização monetária.

Segundo Arretche (2004), ao instituir um sistema legal de repartição de receitas, a Constituição de 1988 limitou a capacidade do governo federal de coordenação de políticas, por restringir sua capacidade de gasto. Não obstante, a despeito das tendências dispersivas resultantes do arranjo federativo desenhado, o governo federal dispõe de instrumentos para coordenar políticas sociais, de recursos institucionais para induzir as decisões e o comprometimento dos governos subnacionais, o que é essencial para que se possa viabilizar e garantir níveis básicos de produção de serviços sociais. Nesse sentido, para Arretche (prelo), é forçoso reconhecer a enorme interdependência entre os níveis de governo na provisão de políticas públicas ${ }^{3}$. Não se trata, sob essa perspectiva, de opor

${ }^{3}$ Essa grande imbricação entre os níveis de governo tem forte impacto sobre as margens de autoridade dos entes federados. Assim, a descentralização de competências não pode ser tida, como quer grande parte da literatura, como equivalente "à autonomia decisória dos governos locais para 
centralização e descentralização, cooperação e competição e interdependência e autonomia. Como preceitua Pierson (1995, p. 458), "The interplay between national and constituent unit officials entails a much more complex mixture of competition, cooperation, and accommodation". O que se busca é a obtenção de um jogo de soma positiva, por meio da instituição de dispositivos efetivos de cooperação entre os três níveis de governo.

Segundo Arretche (2004), para cada política pública específica, o modo como estão estruturadas as relações federativas afeta diretamente a capacidade de coordenar ações entre as esferas de governo. Na política de saúde, por exemplo, cabe ao governo federal financiar e formular a política nacional, coordenando as ações intergovernamentais e induzindo as escolhas dos governos locais. Estados e municípios participam do processo de formulação da política de saúde por meio de conselhos institucionalizados. Já na política de educação fundamental, estados e municípios atuam de modo independente, com competências concorrentes. O governo federal não é o principal financiador da política e o Fundo de Manutenção e Desenvolvimento da Educação Básica e de Valorização dos Profissionais da Educação (FUNDEB) foi instituído visando à redução das assimetrias das unidades subnacionais e à promoção de uma política de valorização dos profissionais da educação. O impacto do federalismo em cada política pública, portanto, deve ser analisado à luz do desenho das instituições políticas e dos recursos de poder dos diversos atores relevantes.

Historicamente, o sistema de segurança pública brasileiro sempre esteve fortemente identificado com as instituições policiais, responsáveis pelo controle da lei e da ordem. Desde a República, a segurança pública alterna períodos de descentralização federativa - com forte centralidade nos estados, nos períodos democráticos (1889-1930, 1946-1964 e a partir de 1984) - com períodos de alta centralização federativa, marcados pela tutela federal das polícias estaduais, nos períodos autoritários (1937-1945 e 1964-1985). O padrão de controle das instituições policiais, portanto, oscila entre a tutela federal e sua centralização nos estados.

definir o modo como serão implementadas as políticas sob sua competência" (ARRETCHE, prelo). Para a autora, a descentralização não implica necessariamente, como pensava grande parte dos constituintes de 1988 e dos atores sociais que incidiram no processo, em democratização do nível local, "podendo até mesmo aumentar as desigualdades, a depender dos arranjos institucionais que estruturam as relações intergovernamentais" (ARRETCHE, prelo). 
A Constituição Federal de 1988, no que se refere à política de segurança pública, manteve a histórica centralização da política nas instituições policiais dos estados $^{4}$ (ainda que estas tenham ficado, nos períodos autoritários da república, como mencionado anteriormente, sob tutela dos governos centrais). Há até pouco tempo, não se pensava na articulação de uma política nacional de segurança pública, nem tinha o governo federal a preocupação de atuar de forma a promover cooperação intergovernamental ou de, por meio de incentivos, induzir as unidades subnacionais a adotarem determinada política. Aos municípios também não cabia qualquer outro papel, que não o de vigiar seus próprios, bens e instalações e o de arcar com alguns dos custos das polícias estaduais atuantes no seu território, como o pagamento de aluguéis, reformas, fornecimento de combustível e cessão de próprios $^{5}$.

Anos após a promulgação da Constituição Federal, a União e alguns municípios passaram a pautar o tema da segurança pública em suas agendas e a chamar para si atribuições não positivadas no sistema de segurança pública constitucional. A União e os municípios têm surgido, como se verá adiante, como atores relevantes nessa política, alterando, ainda que de maneira incipiente, a dinâmica federativa na matéria. Nesse contexto, a construção de uma política nacional de segurança pública precisa ser amplamente negociada e legitimada a fim de que se criem condições efetivas para o trabalho coordenado e cooperativo, visando a maior eficácia e efetividade da política.

\footnotetext{
${ }^{4}$ Sobre o poder dos governos estaduais decorrente do desenho constitucional de 1988, enquanto Souza (2005) chama a atenção para o problema de sua limitada capacidade de iniciativa, em razão da redução relativa de suas receitas e da relação direta que passou a existir entre governo federal e municípios por conta da descentralização de políticas públicas, Abrucio (2005) ressalta o estabelecimento, nas décadas de 1980 e 1990, de um federalismo não-cooperativo nas relações intergovernamentais, com forte predomínio do componente estadualista. Para esse autor, os governadores, nas décadas mencionadas, tiveram seu poder fortalecido e formaram coalizões pontuais e defensivas, visando à manutenção do status quo. Reconhecendo as diferenças no modo como se estruturam as relações federativas em cada política pública, no que diz respeito à política de segurança pública especificamente, a leitura de Abrucio sobre o predomínio do componente estadualista se mostra mais pertinente.

${ }^{5} \mathrm{Em}$ geral, essa contribuição dos municípios para as polícias estaduais se dá há décadas, por força da tradição. Não há qualquer normativa ou instrumento de cooperação firmado entre estados e municípios regulando esse pagamento. Além disso, a contribuição não confere ao município prerrogativa alguma para discutir o trabalho policial. Em municípios da região metropolitana de São Paulo, como São Bernardo do Campo, São Caetano do Sul e Osasco, por exemplo, a realidade é que não há sequer uma rubrica no orçamento municipal reservada a esse pagamento, que é retirado da rubrica "despesas gerais do município". Seria necessária uma pesquisa mais ampla, junto a uma amostra significativa de municípios, para aprofundar o tema.
} 
No que diz respeito à segurança pública, o arranjo federativo desenhado pela Constituição de 1988 potencializa a tendência dos estados de defenderem a manutenção do status quo, ao mesmo tempo em que tende a diminuir a capacidade de incidência de outros atores políticos. Por essa razão, a tentativa de se construir uma política nacional de segurança pública, com coordenação e cooperação intergovernamental, envolvendo os três níveis de governo, não é tarefa fácil e pressupõe um amplo processo de negociações e repactuações.

Diferentemente do que ocorre na política de saúde, por exemplo, em que há um modelo constitucional unificado, integrado e hierarquizado de gestão de competências comuns (o Sistema Único de Saúde - SUS), que favorece a coordenação governamental pelo governo federal, na política de segurança pública a centralidade constitucionalmente atribuída aos estados para a manutenção da lei e da ordem, dentro do clássico paradigma repressivo-punitivo de enfrentamento da violência, tem colocado entraves à eficiência da gestão no setor, gerando muitas vezes conflitos de titularidade e dificuldades para uma efetiva coordenação da política (KINZO et al., 2004).

Pesquisa realizada entre os anos de 2003 e 2004 pelo Programa Nacional de Apoio à Modernização da Gestão e do Planejamento dos Estados e do Distrito Federal (PNAGE) revelou que a pior avaliação em termos de articulação intergovernamental foi a da política de segurança pública, em razão de faltar-Ihe "diretriz federativa clara, dado que não há definição do papel dos entes e da maneira como se deve dar o entrelaçamento entre os três âmbitos" (ABRUCIO; GAETANI, 2006).

Segundo Abrucio (2005, p. 41), para que se possa ter melhor desempenho governamental e maiores efetividade e eficácia das políticas públicas, é necessária uma maior coordenação intergovernamental nos países federativos, ou seja, novas formas de "integração, compartilhamento e decisão conjunta". Na área da segurança pública, em que dispositivos de cooperação intergovernamental quase nunca estiveram presentes (COSTA; GROSSI, 2007; DURANTE, 2008), um arranjo institucional mais cooperativo demanda uma repactuação federativa, com o reconhecimento da inclusão de novos atores políticos nesse campo.

No período pós-transição democrática, a dinâmica federativa, no caso da política de segurança pública, vem sofrendo pequenos deslocamentos em função 
daquilo que os governos são efetivamente capazes de fazer a cada conjuntura e mediante as coalizões que os sustentam. Nesse sentido, torna-se relevante analisar os tensionamentos federativos na matéria e analisar como os governos, em âmbito federal, têm pautado o tema da segurança pública em suas agendas.

\subsection{Perspectiva institucional: considerando instituições, processos e atores}

Para o neoinstitucionalismo, o conceito de instituição é amplo e compreende tanto regras e instituições formais como significados e práticas compartilhados ao longo do tempo, que orientam a ação humana (FREY, 2002). Segundo Hall e Taylor (2003), os teóricos do institucionalismo histórico não consideram as instituições como o único fator que influencia a vida política, mas as situam numa cadeia causal da qual fazem parte outros fatores, como o desenvolvimento econômico e a difusão das ideias.

Instituições importam para se compreender a formulação das políticas públicas. Os atores políticos atuam em contextos institucionais, e esses contextos afetam seus cálculos estratégicos bem como suas preferências. Nas palavras de Immergut (1996, p. 162), "para compreender o impacto das instituições sobre os conflitos políticos contemporâneos, é preciso analisar os incentivos, as oportunidades e as restrições que elas oferecem aos atores envolvidos nas disputas em curso". Para essa autora, nesse sentido, as instituições condicionam estratégias e preferências dos atores, embora não permitam predizer suas escolhas finais.

O pressuposto das teorias neoinstitucionalistas é que "as possibilidades da escolha estratégica são determinadas de forma decisiva pelas estruturas políticoinstitucionais, inclusive a capacidade dos atores políticos de modificar essas estruturas de acordo com suas estratégias" (NABMACHER, 1991 apud FREY, 2002, p. 233). As instituições estruturam as interações e criam incentivos e restrições ao comportamento dos atores, conformando suas preferências e seus recursos, sempre assimétricos na comunidade política. Para uma mesma política e para uma mesma janela de oportunidade há diversos desenhos possíveis de política. As preferências dos diferentes atores políticos e a formação de coalizões majoritárias, para as quais 
os atores relevantes convergem, são afetadas pelas escolhas políticas anteriores, assim como os cálculos estratégicos dos atores são afetados pelas regras do jogo, pelo contexto institucional que rege a interação entre eles.

Para o neoinstitucionalismo histórico, o legado histórico influencia a gênese, as reformas e o fim das políticas públicas. O padrão de dependência da trajetória (path dependence), entendido como um alto custo de reversão da política (PIERSON, 2004), ajuda a compreender os limites das mudanças institucionais. As escolhas futuras, nesse sentido, são condicionadas pelo legado das escolhas anteriores, pelo alto custo de reversão.

Ao postular que as instituições importam e que importa seu desenvolvimento histórico, o neoinstitucionalismo histórico apresenta uma chave explicativa para a compreensão de fatores que contribuem ou que criam obstáculos à implementação de reformas institucionais. Importa para o estudo da política de segurança pública compreender os motivos pelos quais esta parece ser tão resiliente a mudanças e quais fatores têm possibilitado pequenos deslocamentos em algumas de suas características. Importa compreender quais são os atores relevantes na comunidade da política, quais são suas preferências e como as instituições regem suas interações e conformam suas estratégias. 


\section{Capítulo 2 - Política de segurança pública brasileira: características e panorama histórico}

Pode-se afirmar, sinteticamente, que a política de segurança pública brasileira, logo após a promulgação da Constituição Federal de 1988, apresenta as seguintes características, que serão melhor detalhadas ao longo do presente estudo:

1. Ênfase no modelo repressivo-punitivo - a segurança pública é realizada pelas instituições estatais responsáveis pela manutenção da lei e da ordem, com ênfase na repressão e na punição. As polícias tendem a agir reativamente, objetivando mais o combate ao criminoso e o encarceramento do que a prevenção da violência e da criminalidade.

2. Centralidade da política nas instituições policiais estaduais - o desenho da Constituição Federal de 1988 confere às instituições policiais estaduais e federais a execução da política de segurança pública. As instituições policiais estaduais mantêm a centralidade do sistema porque são responsáveis pelo enfrentamento de maior número de tipos penais, que são também os mais frequentes. A Polícia Federal responde apenas pelos crimes de competência federal. A concepção hegemônica vigente em nossa história republicana, de que os Estados são responsáveis pela implementação das ações de segurança pública, fez com que $90 \%$ do efetivo policial do país pertença aos governos estaduais, que também gerenciam $83 \%$ dos recursos gastos na área (DURANTE, 2008).

3. Fragmentação das instituições policiais e padrão dual de policiamento ${ }^{6}$ existência de duas polícias estaduais que não realizam o ciclo completo da atividade policial, isto é, não atuam desde o policiamento ostensivo até a investigação do delito. À polícia militar competem as funções de polícia ostensiva e de preservação da ordem pública. A polícia civil é polícia judiciária, competindo-lhe a investigação dos delitos.

\footnotetext{
${ }^{6}$ O padrão dual de policiamento difere do que ocorre na maioria dos países, em que, mesmo havendo mais de uma polícia, cada uma delas é responsável pelo ciclo completo da atividade policial, isto é, cada uma realiza tarefas que vão desde o momento anterior ao crime até sua posterior investigação. É o caso, por exemplo, do Canadá, onde tanto a Polícia Nacional como a Guarda Nacional desenvolvem, na atividade policial, funções de investigação, prevenção e repressão, na manutenção da ordem pública. A diferença é que a Polícia Nacional atua nas zonas urbanas e está vinculada ao Ministério do Interior, enquanto a Guarda Nacional atua nas zonas rurais, tem formação militar e subordina-se ao Ministério da Defesa (LÉVY, 2008).
} 
4. Militarização do policiamento ostensivo - a função de policiamento ostensivo, que é de natureza civil, é exercida por uma polícia militarizada, com regulamentos disciplinares adequados a instituições militares, com organização militar e vinculada ao Exército, constituindo-se como reserva e força auxiliar dessa instituição.

5. Presença do instituto do inquérito policial - instrumento administrativo de investigação da polícia civil que confere à autoridade policial a prerrogativa de indiciar o suspeito e de produzir provas sem a aplicação do princípio do contraditório.

6. Ausência de uma política nacional de segurança pública e carência de mecanismos institucionais de coordenação e cooperação intergovernamentais.

7. Ausência do município como cogestor da segurança pública (ressalvada apenas a possibilidade de constituição de guardas municipais para a preservação de bens, serviços e instalações municipais).

8. Inexistência ou ineficiência de mecanismos de controle externo das instituições policiais e fragilidade dos mecanismos de controle interno.

9. Comunidade da política restrita aos atores vinculados às instituições responsáveis pelo controle da lei e da ordem.

Este capítulo tem por objetivo demonstrar como algumas dessas características foram engendradas historicamente, como foi o tratamento dado a essa política no curso do processo constituinte de 1987-1988, como ficou configurado o desenho constitucional de então, bem como alguns problemas decorrentes desse arranjo institucional.

A caracterização da política é importante para que se possa, no decorrer do trabalho, analisar se houve algum impacto das políticas posteriores sobre ela. A reconstituição histórica da política de segurança pública no Brasil permite que se tenha um panorama da gênese e da evolução de suas principais instituições. Conhecer as escolhas institucionais passadas possibilita compreender limitações a escolhas futuras, em razão dos altos custos que mudanças radicais no modelo da política podem impor, como será mais bem explicado na seção 4.5 do capítulo 4 . 


\subsection{Caracterização histórica do modelo de segurança pública brasileiro}

No início do período colonial, antes da chegada da Família Real ao Brasil, em 1808 , a segurança nas cidades e vilas era feita de forma privada pelos quadrilheiros e capitães-do-mato, especializados na captura de escravos fugitivos. Valendo-se desse poder disciplinador privado dos senhores de terras, Portugal instituiu as chamadas ordenanças, que outorgavam funções de mando a esses "chefes naturais" (LEAL, 1997). Com a chegada da Família Real, D. João VI instituiu o cargo de "Intendente Geral da Polícia da Corte e Estado do Brasil", que tinha por atribuição zelar pela segurança da Família Real e pela segurança coletiva, realizando o policiamento dos logradouros públicos, a investigação de crimes e a captura de criminosos. Competia, também, ao Intendente Geral decidir sobre condutas consideradas ilícitas, determinando prisões e solturas, realizando julgamentos e supervisionando o cumprimento da penas ${ }^{7}$.

Durante o império, na esteira das discussões da época entre liberais e conservadores, ocorreu um movimento pendular de centralização e descentralização das funções judiciárias e policiais. Com a abdicação de D. Pedro I, em 1831, o Estado viveu momentos de incertezas e desordens. Movimentos revolucionários, insurgentes por todo o país, motivaram a criação, em 1831, da Guarda Nacional e do Corpo de Guardas dos Permanentes, no Rio de Janeiro, que substituíram os corpos de milícias e as ordenanças. O mesmo decreto regencial que instituiu a Guarda dos Permanentes autorizava os presidentes de províncias a instituírem suas próprias guardas, forças policiais de estrutura militarizada ${ }^{8}$. Segundo Fernandes (1974) apud Lima (2006),

[...] a característica híbrida da organização do Corpo de Guardas de Permanentes [...] tinha uma estrutura contraditória que contribuía para o estabelecimento de conflitos, de um lado, com a instituição essencialmente

\footnotetext{
${ }^{7}$ Segundo Leal (1977, p. 370), os efeitos dessa mistura de competências administrativas, policiais e judiciárias se projeta até os dias atuais, "como se vê do inquérito policial pela polícia e que serve de base à ação penal".

${ }^{8}$ A gênese das polícias militares remonta a essas forças policiais militarizadas instituídas ainda no Brasil imperial (LIMA, 2006). Outros autores apontam que o embrião mais antigo da polícia militar é, na verdade, a Guarda Real de Polícia, criada em 1809, por D. João VI, no estado da Guanabara. "Essa guarda era subordinada ao governador das Armas da Corte que era o comandante de força militar, que, por sua vez, era subordinado ao intendente-geral de Polícia" (SOUZA, s/d).
} 
militar, o Exército; de outro, com a instituição tradicionalmente policial, a Polícia Civil. (LIMA, 2006, p. 136)

Para Dallari (1991), foi equivocada a forma como, em 1831, autorizaram-se as províncias a criar sua organização policial, porque, na prática, criaram-se pequenos exércitos provinciais, equívoco esse que, até os dias atuais, marca a confusão existente entre autoridade policial e autoridade militar $^{9}$.

O Código de Processo Criminal, editado em 1832, tinha uma tendência liberal descentralizadora. Cada comarca tinha um juiz de direito, investido também da função de chefe de polícia. A intenção inicial, ao se instituir a descentralização do controle da ordem pública para o poder local, era a de que se conseguisse, a partir da administração distrital, combater a desordem pública e fortalecer as corporações policiais. No entanto, as instituições policiais foram sendo instrumentalizadas politicamente pelas elites rurais controladoras do poder local e ficaram sujeitas aos caprichos locais, sem que os governos provinciais e central pudessem intervir (LIMA, 2006). Segundo Leal (1977), a lei de 1832 mostrou-se ineficiente para prevenir e reprimir a criminalidade, e todas as desordens e revoluções do período regencial foram atribuídas a ela.

Em reação ao arranjo organizativo descentralizador de 1832, vários rearranjos foram adotados, culminado na reforma de 1841, marcada pelos ideais conservadores de manutenção da unidade nacional e de controle da ordem. Pela primeira vez, o Regulamento 120 , de 31 de janeiro de 1842, regulamentou a divisão das funções policiais, dispondo sobre a polícia administrativa e a polícia judiciária. Vem daí uma das principais características do sistema de segurança pública brasileiro presente até os dias atuais: a escolha por um padrão dual de gestão na segurança pública (LIMA, 2006), caracterizado por duas polícias de ciclo incompleto, uma responsável pelas funções investigativas e judiciárias e a outra responsável pelas funções ostensivas e de preservação da ordem pública.

A reforma seguinte, em 1871, manteve a estrutura organizativa da lei de 1841, aceita, ao final, inclusive pelos liberais, em razão de sua maior eficiência

\footnotetext{
${ }^{9}$ Percebe-se, ao longo da história até os dias atuais, que a função de policiamento ostensivo sempre esteve de alguma forma ligada à organização militar. O soldado de polícia era um militar que integrava as forças policiais, subordinadas aos presidentes de estado e, posteriormente, governadores, tendo recebido diferentes denominações, como Guarda Municipal Permanente, Brigada Militar, Força Pública, entre outras. Desde o Segundo Império, a polícia ostensiva (hoje denominada Polícia Militar) atuava de forma regular como força auxiliar do Exército, tanto nos conflitos armados externos como nos levantes internos (MUNIZ, 2001).
} 
administrativa. As autoridades policiais passaram a ficar impedidas de proceder à formação de culpa e de pronunciar os delinquentes, mas continuavam a processar pequenos delitos. Pelo disposto na Lei 2.033, de 20 de setembro de 1871, instituiuse o inquérito policial, existente até hoje, incumbindo-se às autoridades policiais a realização das "diligências necessárias ao descobrimento dos crimes e suas circunstâncias" (KFOURI FILHO, 1991).

No período republicano, o federalismo de 1891 deixou a cargo dos estados a organização de seu aparelhamento estatal (LEAL, 1977), tornando a centralidade das funções policiais nos estados uma marca desse período histórico, presente até os dias atuais ${ }^{10}$. Na Primeira República, as polícias militares estaduais cresceram com a implantação do federalismo. Alguns estados, como São Paulo, Minas Gerais e Rio Grande do Sul, transformaram suas polícias em pequenos exércitos (CARVALHO, 2003; DALLARI, 1977) utilizados como instrumentos na disputa pelo poder político ${ }^{11}$.

Com o final da Primeira República, o Exército exigiu que as polícias militares ficassem sob seu controle. Na longa fase de autoritarismo político da Era Vargas, o sistema policial foi utilizado como instrumento de repressão política e de práticas arbitrárias contra os cidadãos. No período entre 1946 e 1964, restabeleceu-se o controle dos governadores sobre as polícias, mas estas permaneceram, conforme 0 desenho constitucional de $1946^{12}$, como forças auxiliares e reservas do Exército, tal como havia sido previsto inicialmente na Constituição Federal de $1937^{13}$.

A Constituição Federal de 1946 passou a denominar as forças policiais dos estados de "polícias militares". Mas foi apenas no regime militar, iniciado em 1964, que a denominação foi padronizada ${ }^{14}$ e seus comandos entregues a oficiais do

\footnotetext{
${ }^{10}$ As limitações, ainda hoje existentes, do caráter estadual da organização policial são de duas ordens: o fato de as polícias militarizadas constituírem reservas do Exército e as atribuições que competem à atualmente denominada Polícia Federal (LEAL, 1977).

${ }_{11}$ Vários autores chamam a atenção para a instrumentalização das polícias por partidos políticos e pela elite dominante. Medeiros (2004) ressalta que, desde sua gênese, as polícias foram constituídas a serviço das elites para exercerem controle social. Leal (1977) chama a atenção para a instrumentalização da polícia para fins políticos, especialmente eleitorais.

12 O artigo 183, integrante do Título VII - "Das Forças Armadas", da CF de 1946, dispunha: "As polícias militares, instituídas para a segurança interna e a manutenção da ordem nos Estados, nos Territórios e no Distrito Federal, são consideradas, como forças auxiliares, reservas do Exército".

${ }^{13}$ A CF de 1934 já estabelecia que as polícias militares eram forças reservas do Exército, mas ainda não as estabelecia como forças auxiliares deste.

${ }^{14}$ As exceções foram o estado do Rio Grande do Sul, que até hoje denomina sua força policial militar de Brigada Militar, e o estado de São Paulo, que manteve a denominação de Força Pública até 1970.
} 
Exército brasileiro, objetivando um rígido controle sobre as corporações e a coibição de eventuais tentativas de levante armado por parte dos estados.

Durante o regime militar iniciado em 1964, as polícias militares foram colocadas totalmente sob o comando do Exército, recebendo intenso treinamento militar e sendo dotadas de órgãos de inteligência e de repressão política. As Forças Armadas - e não mais as polícias, como havia ocorrido na ditadura Vargas passaram a controlar a repressão política. Foi criada, em 1967, a Inspetoria Geral das Polícias Militares (IGPM) do Ministério do Exército, com o objetivo de supervisionar e controlar as polícias militares estaduais, supervisão esta que segue sendo feita até hoje, embora não exista mais a tutela centralizadora do governo federal sobre as polícias, característica dos períodos autoritários.

2.2 Segurança pública no processo constituinte e o desenho da política de segurança pública na Carta de 1988

A redemocratização, com sua luta pela restauração do federalismo e pela descentralização, conduziu a um intenso processo de participação política e de mais de um ano de trabalho da Assembleia Nacional Constituinte para a elaboração de uma nova Constituição, com dispositivos relativos não só a princípios e direitos (individuais, coletivos e difusos), mas também a várias políticas públicas, resultando numa Carta longa e detalhada. Não obstante essa grande janela de oportunidades, a Constituição de 1988, no que diz respeito à segurança pública, manteve parte dos dispositivos presentes na Constituição de 1967, outorgada no período autoritário militar, e na Emenda de 1969.

Para que se possa proceder à análise de uma dada política pública, de seu processo de formulação e implementação, é essencial que se compreendam as regras do jogo e os arranjos políticos e institucionais vigentes, como se procurará fazer nesta seção. No caso brasileiro, assim como no de outros países latinoamericanos, o fim do período autoritário militar se deu com a saída das Forças Armadas de forma negociada, sem rupturas. Para assegurar a concordância das forças militares em devolver o governo aos civis, manteve-se certo grau de 
autonomia política dos militares. A chamada "distensão lenta, gradual e segura" impôs, assim, dificuldades e limites às mudanças, no que concerne à construção do controle civil no processo de consolidação democrática brasileira. (SAINT-PIERRE; WINAND, 2007).

As preferências estratégicas das Forças Armadas prevaleceram no processo constituinte em relação à política de segurança pública. $O$ fato de as Forças Armadas serem atores políticos que, diferentemente de outros, têm a capacidade de reverter o processo de democratização pelas armas, tornava ainda maior seu poder de barganha política. Para o neoinstitucionalismo histórico, fatores exclusivos de um grupo de interesse não são suficientes para explicar sua influência política. Esta abrange a relação desse determinado grupo de interesse com o sistema político e só pode ser compreendida por meio de "uma análise da receptividade das instituições às pressões políticas" (IMMERGUT, 1996, p. 146).

Segundo Arturi (2001),

[...] a aceitação da eleição de Tancredo pelos militares foi baseada, quase que exclusivamente, na sua "confiabilidade" política pessoal, que garantiria tanto o cumprimento das prerrogativas políticas oferecidas às Forças Armadas como as promessas de que os interesses econômicos fundamentais das classes dominantes não seriam atingidos por eventuais reformas.

Cercado de constrangimentos à consolidação do novo regime, Sarney apoiouse politicamente nos militares e utilizou práticas clientelistas para aliciar parlamentares de vários partidos ${ }^{15}$. Ao lado de Sarney, o Ministro do Exército, General Leônidas Pires, emitia opinião não apenas sobre temas pertinentes à sua pasta, mas sobre todos os assuntos considerados importantes (SAINT-PIERRE; WINAND 2007).

Diferentemente do que se verificava em relação a outras políticas públicas, não havia, à época, uma coalizão reformadora para que se estabelecesse um novo modelo institucional para a segurança pública, o que não significa dizer que não existissem atores com agendas reformistas. Era o caso, por exemplo, da Comissão Justiça e Paz, do Gabinete de Assessoria Jurídica às Organizações Populares (GAJOP), em Pernambuco, e do Movimento Nacional de Direitos Humanos, entre

\footnotetext{
${ }^{15}$ Segundo Celina Souza (2001, p. 540), o presidente Sarney "valeu-se dos militares como uma força extraconstitucional para diminuir o poder dos partidos de esquerda e dos movimentos sociais".
} 
outros. Segundo Kant de Lima (2000, p. 56), desde a década de 1980, setores da sociedade já rejeitavam a militarização da ação policial, postulando a remodelação e a modernização das instituições policiais, bem como a adoção de estratégias orientadas pelos direitos humanos. Coexistiam duas posições políticas antagônicas, consubstanciadas em discursos conservadores autoritários e em discursos de defesa dos direitos humanos (o que continuou evidente durante toda a década de 1990).

Havia, à época, um forte lobby, bastante ativo e organizado pelos interesses militares, com 13 oficiais superiores atuando junto aos constituintes (STEPAN, 1988; ZAVERUCHA, 2002). Durante o processo constituinte, o então senador Jarbas Passarinho, coronel da Reserva e ex-ministro dos governos dos Generais Costa e Silva, Médici e Figueiredo, presidiu a Comissão de Organização Eleitoral Partidária e Garantia das Instituições, encarregada da redação dos capítulos sobre Forças Armadas e Segurança Pública. O deputado Ricardo Fiúza, um dos líderes do denominado "Centrão"16, era encarregado da subcomissão de Defesa do Estado, da sociedade e de sua segurança, e deu total apoio às demandas militares, trabalhando, segundo Zaverucha (2002), contra qualquer tentativa de se acabar com o controle do Exército sobre as polícias estaduais. A aludida subcomissão organizou oito sessões públicas, convidando 28 pessoas, cujos perfis tornavam previsível a preferência pela agenda militar. Apenas três dos vinte e oito convidados (o presidente da Associação Nacional dos Comissários da Polícia Civil, o presidente da Ordem dos Advogados do Brasil e o diretor do Núcleo de Estudos Estratégicos da Unicamp) apresentaram proposituras de mudanças nas relações entre civis e militares. A agenda para a segurança pública entre os constituintes refletia, portanto, a preferência dos militares pela manutenção do status quo.

Contreiras, citado por Zaverucha (2002, p. 84), afirma que o coronel do Exército, Sebastião Ferreira Chaves, ex-secretário de segurança pública de São Paulo no Governo Abreu Sodré, entendia, já naquela época, que a polícia militar agia de forma violenta e que a polícia civil havia perdido sua capacidade investigativa. Por esse motivo, tentou convencer o então presidente do Congresso

\footnotetext{
${ }^{16}$ Centrão é a denominação que se deu a um movimento de parlamentares constituintes filiados a partidos de centro direita. Como afirma SOUZA (2001, p.539), o grupo foi articulado para "lutar contra o que muitos rotulavam de tendências esquerdistas da Assembleia Nacional Constituinte."
} 
Nacional, deputado Ulisses Guimarães, a mudar o sistema policial na Constituição de 1988, extinguindo, entre outras medidas, as polícias militares. Segundo o autor, o presidente do Congresso expressou a impossibilidade da mudança, em razão de acordo que firmara com o General Leônidas Pires, ministro do Exército do Governo Sarney. Nesse sentido, a lógica do processo de decisão, como afirma Immergut (1996), requer a análise de todos os acordos que ocorrem ao longo da cadeia de decisões tomadas por representantes de diferentes arenas políticas.

As preferências pela manutenção do status quo prevaleceram, traduzindo-se na continuidade de arranjos institucionais persistentes em matéria de segurança pública. O poder de pressão do Exército mostrou-se relevante; mostraram-se significativas também as manobras políticas para a conformação de arranjos no curso do processo decisório constituinte. Importaram as estratégias para que fosse possível uma transição democrática negociada. Não havia, por parte do poder executivo federal, uma agenda reformista na área de segurança pública e também não se havia constituído uma coalizão reformadora a partir de setores da sociedade civil críticos ao modelo herdado do período autoritário.

A Constituição Federal de 1988 conferiu aos membros das polícias militares o status de servidor público militar e manteve a competência dos tribunais militares estaduais para o julgamento também dos crimes cometidos por policiais militares. Reafirmou as polícias militares e corpos de bombeiros militares como forças auxiliares e reserva do Exército e preservou a divisão entre polícia militar e polícia civil, subordinando-as aos governadores estaduais.

Em relação às competências que dizem respeito à segurança pública, o desenho constitucional ficou assim configurado: compete privativamente à União legislar sobre "normas gerais de organização, efetivos, material bélico, garantias, convocação e mobilização das polícias militares e corpos de bombeiros militares" e sobre a "competência da Polícia Federal e das polícias rodoviária e ferroviária federais" (art. 22, inc. XXI e XXII). À União e aos estados compete concorrentemente legislar sobre "organização, garantias, direitos e deveres das polícias civis" (art. 24, inc. XVI). Zelar pela guarda da Constituição, das leis e das instituições democráticas e conservar o patrimônio público é competência comum de todos os entes federados (art. 23, inc. I). 
O artigo 144, que trata especificamente da política de segurança pública, dispõe que:

A segurança pública, dever do Estado, direito e responsabilidade de todos, é exercida para a preservação da ordem pública e da incolumidade das pessoas e do patrimônio, através dos seguintes órgãos: I - Polícia Federal; II - Polícia Rodoviária federal; III - Polícia Ferroviária Federal; IV - polícias civis; $\mathrm{V}$ - polícias militares e corpos de bombeiros militares.

O parágrafo $7^{\circ}$ do mesmo dispositivo constitucional dispõe que "a lei disciplinará a organização e o funcionamento dos órgãos responsáveis pela segurança pública, de maneira a garantir a eficiência de suas atividades". Aos municípios, o parágrafo $8^{\circ}$ do art. 144 faculta a criação de guardas municipais, apenas para a guarda de seus bens, serviços e instalações.

Considerada dever do Estado e direito e responsabilidade de todos, a segurança pública passou a ocupar capítulo próprio na Constituição, inserido no Título V, "Da Defesa do Estado e das Instituições Democráticas", ao qual se vinculam também os capítulos que versam sobre o estado de defesa e o estado de sítio e o capítulo sobre as Forças Armadas. Vários autores (CARBALLO BLANCO, 2000; LIMA; MISSE; MIRANDA, 2000; MUNIZ; ZACCHI, 2005) apontam uma mudança positiva de foco na Constituição de 1988, que introduziu o conceito de segurança como preservação da ordem pública, dissociando-o das instituições de defesa nacional. Não obstante, mantiveram-se inalterados tanto o modelo da política como a organização e as estruturas das instituições policiais. $O$ poder das Forças Armadas continuou a se refletir em vários dispositivos constitucionais ${ }^{17}$. Assim, apesar da mudança de foco, o desenho constitucional de 1988, no que tange à estrutura e à organização das instituições de segurança pública, acabou resultando basicamente em continuidades.

\footnotetext{
${ }^{17}$ Não apenas no artigo 144 da Constituição Federal, que manteve as polícias militares como forças "auxiliares e reservas do Exército", mas em vários outros dispositivos da Carta de 1988 fica evidente o poder e a influência das Forças Armadas. O artigo 142 do capítulo relativo às Forças Armadas dispõe que estas se destinam "à defesa da pátria, à garantia dos poderes constitucionais e, por iniciativa de qualquer destes, da lei e da ordem". Segundo Zaverucha (1998), na primeira versão dada ao artigo 142, os militares perdiam o papel de guardiões da lei e da ordem, mas, constrangidos pelo então ministro do Exército, Leônidas Pires, os constituintes acabaram alterando a sua redação. Sobre o tema ver também Saint-Pierre e Winand (2007).
} 
2.3 Arranjo institucional do sistema de segurança pública e alguns problemas dele decorrentes

A presente seção tem por objetivo identificar conflitos e deficiências presentes no modelo da política de segurança pública vigente, cujas características, conforme analisado nas seções precedentes, deitam raízes em escolhas passadas e persistentes ao longo do tempo. A identificação desses problemas - colocados em evidência nas décadas de 1980 e 1990 com o aumento vertiginoso da criminalidade - permitirá uma melhor compreensão das agendas de reformas incrementais e radicais que se constituíram especialmente nos últimos 15 anos e que serão estudadas do capítulo 4 em diante.

Um primeiro problema, que decorre do desenho constitucional do sistema de segurança pública, refere-se ao duplo comando, estadual e federal, das polícias militares e corpos de bombeiros. No seu artigo 22, XXI, a Carta de 88 relacionou entre as competências privativas da União a de legislar sobre as normas gerais de organização, efetivos, material bélico, garantias, convocação e mobilização das polícias militares e corpos de bombeiros militares. Não obstante, o artigo 144 , parágrafo $6^{\circ}$, subordinou tanto as polícias civis como as militares aos governadores estaduais. De acordo com Zaverucha (2002, p. 85), estabeleceu-se um arranjo institucional bastante explosivo em situação de conflito entre o governador do estado e o presidente da República.

Os governadores ficam com ônus de pagar os salários sem, todavia, poderem decidir qual tipo de armamento deve ser comprado, como as tropas devem ser alinhadas, ou onde devem ser construídos novos quartéis. Para tudo isso, necessitam de consentimento da Inspetoria Geral das Polícias Militares (IGPM), órgão vinculado ao comandante do Exército [...] criado durante o auge da repressão política.

Outro arranjo institucional indutor de conflitos refere-se à fragmentação e ao padrão dual das instituições policiais. As duas polícias estaduais possuem cadeias de comando próprias e independentes, e nenhuma delas realiza o ciclo completo da atividade policial (as atividades de polícia investigativa e judiciária e as atividades de policiamento ostensivo não são desempenhadas por uma mesma instituição policial). O padrão dual das polícias gera dificuldades no que diz respeito à separação entre 
polícia administrativa e polícia judiciária ${ }^{18}$. Sobre esse arranjo conflituoso, Dallari (1991, p. 64) afirma que, na verdade, nunca houve uma diferenciação clara de delimitação de atribuições das polícias militar e civil, motivo pelo qual as duas instituições seguem convivendo e "frequentemente conflitando".

Esse problema não decorre propriamente do fato de existirem duas polícias estaduais, mas principalmente do fato de que elas não realizam o ciclo completo da atividade policial $^{19}$ e de que não atuam integradamente, o que acaba por gerar disputas, rivalidades e conflitos de competência. Na prática, apesar de formalmente não realizarem o ciclo completo, cada uma das duas polícias acaba desenvolvendo atividades que seriam de competência da outra. A polícia investigativa é a polícia civil, mas a polícia militar também exerce essa função, por exemplo, quando instaura inquérito policial militar ou, ainda, nos estados em que as polícias militares reivindicam o direito de lavrar Termos Circunstanciados de Ocorrência ${ }^{20}$. A polícia civil, por sua vez, desenvolve atividade ostensiva, atribuição típica da polícia militar, por meio de alguns de seus agrupamentos especializados, como é o caso, por exemplo, do Grupo de Operações Especiais (GOE), força de elite da polícia civil paulista, cujo objetivo é atuar em ocorrências de alto risco.

Nas palavras de Muniz e Zacchi (2005, p. 15),

[...] as ambiguidades existentes nas definições formais dos mandatos, atribuições e competências das agências policiais e, por outro lado, a falta

\footnotetext{
${ }^{18}$ A doutrina menciona a divisão das funções policiais em polícia administrativa, de caráter ostensivo e atuação preventiva, isto é, antes do cometimento da conduta delitiva; e outra de caráter judiciário, de natureza repressiva, no sentido de atuar depois que o ato criminoso já ocorreu, para que restem esclarecidas as circunstâncias em que se deu o fato e sua autoria. Na prática, no entanto, a polícia militar atua muito mais reativamente, repressivamente, do que de maneira preventiva.

${ }^{19}$ Fazer o ciclo completo da atividade policial (o que ocorre na maior parte das polícias do mundo) significa, como já se afirmou, que uma mesma polícia é responsável tanto pelas atividades de policiamento ostensivo como pelas atividades investigativas. A mesma polícia que faz o policiamento ostensivo, visando a inibir a ocorrência delitiva, persegue o criminoso, efetua sua prisão e toma as medidas de polícia investigativa e judiciária.

${ }^{20} \mathrm{O}$ tema é bastante polêmico. Termo Circunstanciado de Ocorrência (TCO) é o registro que se faz quando da ocorrência de um fato tipificado como infração de menor potencial ofensivo, conforme previsto na Lei 9099/95, conhecida por Lei dos Juizados Especiais. A discussão sobre quem está legitimado a lavrar TCO decorre do previsto no artigo 69 da mencionada lei, segundo o qual, no caso dos crimes de pequeno potencial ofensivo, "a autoridade policial que tomar conhecimento da ocorrência lavrará termo circunstanciado...". Como a função judiciária é privativa da polícia civil, esta entende que o termo "autoridade policial" não se aplica aos policiais militares, dizendo respeito apenas aos delegados de polícia. Já a polícia militar defende a legalidade de ela própria lavrar o TCO, uma vez que deve prevalecer o princípio da instrumentalidade e da prestação do serviço de segurança pública por qualquer uma das duas polícias. A polêmica tem sido resolvida de maneira diferente em cada estado da federação e também tem sido objeto de várias ações judiciais. Sobre o tema ver Lemle (2008).
} 
de expedientes integradores, conduz à multiplicação de conflitos de competência, à sobreposição e ao abandono de rotinas, a não cobertura do fluxo integral do trabalho policial, à duplicidade de gastos, à dispersão de esforços, debilitação das cadeias de comando e de controle e, por fim, ao clientelismo político em torno das polícias pela crítica falta de estruturas de gestão e gerência integradas e de ferramentas efetivas de controle social.

O resultado disso, segundo os autores, é a baixa qualidade dos serviços prestados, com baixa eficiência e eficácia, apesar dos altos custos despendidos para a manutenção das estruturas existentes.

No que diz respeito ao controle interno da atividade policial, sua fragilidade decorre da inexistência de corregedorias policiais autônomas e independentes dos comandos. No que concerne ao controle externo, as insuficiências e as fragilidades também não são pequenas. $O$ Ministério Público, a quem compete constitucionalmente o controle externo das polícias, nem sempre assume essa função e as ouvidorias de polícia, embora constituam inegável avanço no campo do controle social, além de ainda não estarem presentes em todos os estados da federação ${ }^{21}$, não são dotadas de poderes investigativos próprios, o que as torna dependentes da investigação realizada pelos órgãos corregedores policiais.

A baixa eficiência das instituições policiais, tanto para prevenir crimes como para investigá-los, também é outro problema crônico do modelo policial brasileiro. Por um lado, com a transição democrática, a estrutura e o treinamento militarizados das polícias militares mostraram-se inadequados para a função policial de proteção dos cidadãos, em razão da lógica militar ser a do combate e a da eliminação dos inimigos do Estado. Por outro, a dificuldade da polícia civil em investigar ${ }^{22}$, somada às deficiências das outras agências que compõem o sistema de justiça criminal, contribui para um quadro de impunidade e de desconfiança nas instituições. Para muitos autores, o caráter burocrático do qual se reveste o inquérito policial se dá em detrimento da própria eficiência da atividade investigativa (ALBERNAZ, 2009; MISSE, 2009; VARGAS; NASCIMENTO, 2009;). A desconfiança da população em relação à eficiência do sistema, por sua vez, faz não apenas com que grande parte

\footnotetext{
${ }^{21}$ Até 2008 , apenas 14 estados brasileiros tinham instituído ouvidorias de polícia.

${ }^{22}$ A maior parte dos boletins de ocorrência não conduz à abertura de inquérito policial e estes, por sua vez, não produzem relatórios que fundamentem o oferecimento de denúncia pelo Ministério Público.
} 
das ocorrências delitivas sequer seja notificada à polícia ${ }^{23}$, mas fomenta as formas privadas de fazer justiça e contribui para a exacerbação de um sentimento coletivo de medo e de insegurança (ADORNO; ZUMINO, 2000).

Outro problema persistente diz respeito à cultura de não participação da sociedade civil na gestão das políticas de segurança pública. Em geral, a pouca participação se limita aos conselhos comunitários de segurança, como os existentes em São Paulo, por exemplo, desde o Governo Franco Montoro, mas mesmos estes ainda expressam uma atuação pouco plural em termos de representação dos segmentos sociais. Até hoje, são muitos os conselhos marcados por alta representação de comerciantes e cidadãos motivados pela resolução de seus problemas particulares, procurando por vezes privatizar os recursos públicos (DURANTE; ZAVATARO, 2007).

A estrutura centralizada nas instituições policiais estaduais, seu isolamento e fragmentação e a falta de mecanismos de cooperação dificultam a articulação de políticas públicas de segurança nas três esferas de governo, bem como o desenvolvimento integrado de estratégias preventivas da violência, envolvendo a participação comunitária. Essa centralização marcante nas políticas da área de segurança, que "não buscam formas de cooperação, articulação que thes deem respaldo e legitimidade política" (ALVAREZ; SALLA; SOUZA, 2004), leva a fracassos, além de implicar também uma maior dificuldade em se otimizar e potencializar esforços e recursos a fim de se garantir um padrão mínimo de qualidade no provimento de segurança pública em todo o território nacional.

Apesar de todo esse quadro de deficiências, insuficiências e conflitos nas instituições tradicionais da segurança pública ter sido engendrado ao longo de anos de história, apenas há cerca de duas décadas a política de segurança pública ganhou lugar de destaque na agenda política e no debate público. Por que a questão da segurança passou a ser um problema a ser enfrentado pelos governos e pelos formuladores de políticas públicas é o que será analisado a seguir.

\footnotetext{
${ }^{23}$ Pesquisa de vitimização realizada pelo ILANUD, em 2002, no Rio de Janeiro, São Paulo, Vitória e Pernambuco, aponta os altos índices de subnotificação, especialmente no que diz respeito à violência doméstica, estupro, entre outros.
} 


\section{Capítulo 3 - Crise da segurança pública: rupturas e esgotamento do modelo}

No modelo de análise de políticas públicas denominado de arenas sociais (SOUZA, 2007), para que determinada questão ou circunstância se transforme em um problema, as pessoas precisam se convencer de que algo necessita ser feito. Quando isso ocorre, os decisores e formuladores das políticas públicas (policy makers) voltam sua atenção para essa questão em detrimento de outras. Souza (2007) aponta três mecanismos para chamar a atenção dos policy makers: a divulgação de indicadores que expressam a dimensão do problema; a repetição continuada do mesmo problema; e o mecanismo de feedback, isto é, dados e informações que identificam problemas na política atual ou sua baixa efetividade.

No caso da política de segurança pública, esses três mecanismos ficaram evidentes nas décadas de 1980 e 1990, quando o aumento expressivo do crime e da violência colocou em cheque o sistema de justiça criminal brasileiro, composto pelo sistema de segurança pública, pelo poder judiciário e pelo sistema penitenciário. As políticas tradicionais de segurança, repressivas e reativas, que consistem em geral no aumento do número de prisões, ampliação do efetivo policial e aquisição de equipamentos (veículos e armamentos), expuseram não apenas as deficiências do modelo de segurança pública, analisadas no capítulo 2, como também mostraram sua insuficiência para conter a curva ascendente das estatísticas criminais.

As taxas de mortes violentas no Brasil apareceram entre as mais altas do mundo. Em 1980, a taxa era de 11,7 homicídios por 100 mil habitantes, subindo para 27,8 no ano 2000 , o que indica aumento de $244 \%$ em 20 anos. Entre os anos de 1980 e 2001, houve 646.158 homicídios dolosos no país, correspondendo a mais de 30.000 assassinatos por ano (LEMGRUBER, 2004). 


\section{Gráfico da evolução da incidência de homicídios \\ Brasil: 1980 a 2003}

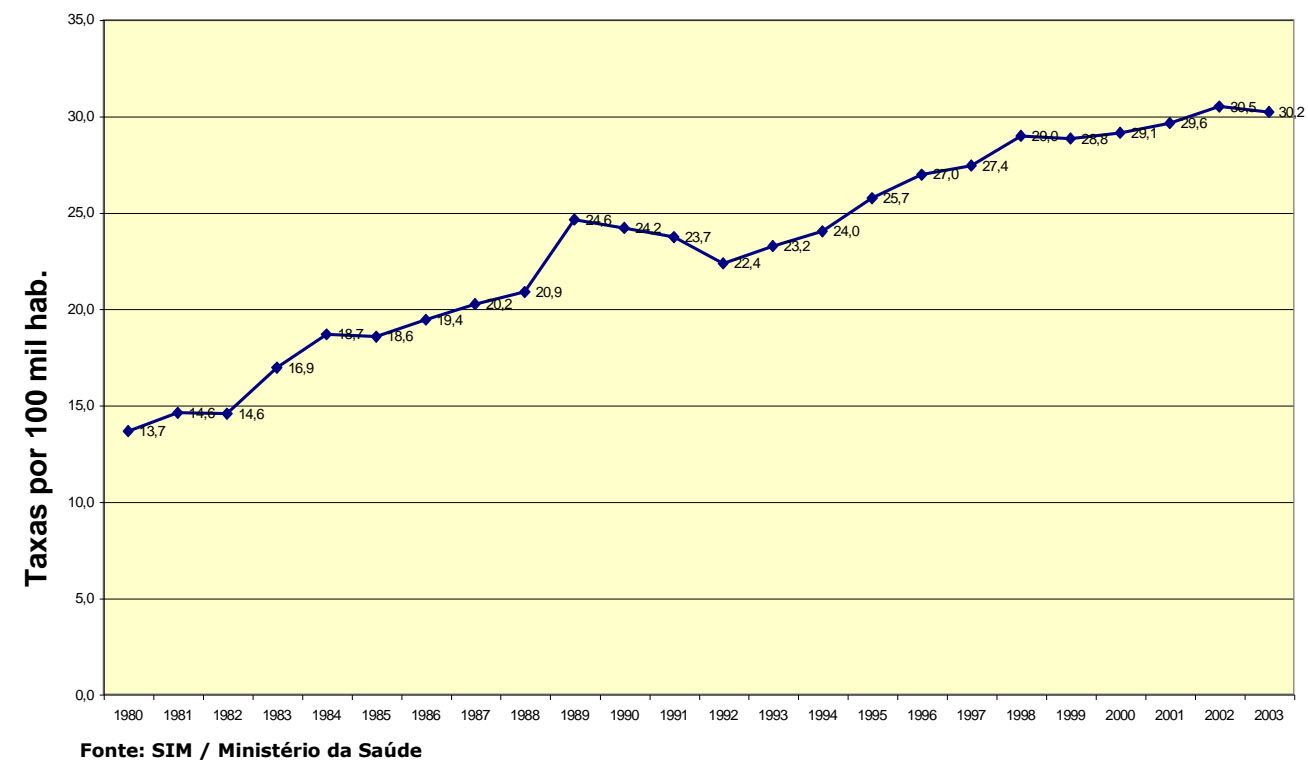

No ano 2000, segundo dados do Centro Internacional de Prevenção ao Crime da Organização das Nações Unidas, o Brasil ocupava a posição de quinto país mais violento do mundo, ficando atrás apenas da Venezuela, Jamaica, África do Sul e Colômbia. A violência policial também atingiu níveis alarmantes. No estado de São Paulo, por exemplo, de 1990 a 2000, a polícia militar matou 7.087 pessoas, segundo dados da Ouvidoria da Polícia do Estado (2000). O crime se organizou. A impunidade se mostrou presente tanto na incapacidade do Estado de punir o responsável pelo crime comum e de conter o crime organizado como na incapacidade de punir seus próprios agentes.

A análise das estatísticas criminais, nas décadas de 1980 e 1990, denota um crescimento vertiginoso não apenas dos crimes dolosos contra a vida, mas de todas as modalidades de crime. Adorno (2002) aponta quatro tendências do crescimento do crime e da violência, nos vinte anos que se seguiram ao fim do regime militar: 1) aumento da violência urbana, especialmente dos crimes dolosos contra a vida (homicídios) e dos crimes contra o patrimônio; 2) surgimento do crime organizado, 
relacionado ao tráfico de drogas internacional; 3) violações graves de direitos humanos; 4) aumento dos conflitos intersubjetivos (conflitos de vizinhança). As causas do aludido crescimento, segundo o autor, giram em torno de três tipos de explicações: mudanças na sociedade e nos padrões convencionais de delinquência e violência; crise do sistema de justiça criminal, compreendendo agências policiais, Ministério Público, tribunais de justiça e sistema penitenciário; e desigualdade social e segregação urbana.

O sistema de justiça criminal é seletivo, punindo preferencialmente marginalizados e pobres (ADORNO, 1994, 2002; WACQUANT, 2001), e é a eles que se dirige, preferencialmente a violência policial e a violência comum, especialmente nos casos dos crimes dolosos contra a vida (MIRAGLIA, 2006; WAISELFIZ, 2006) ${ }^{24}$. O caráter profundamente discriminatório do sistema de justiça criminal também é revelado em pesquisa realizada pela Ouvidoria da Polícia do Estado de São Paulo (2000) que, analisando inquéritos policiais versando sobre homicídios cometidos por policiais no estado de São Paulo, no ano de 1999, apontou que a maior parte das vítimas era negra, jovem e moradora de bairros periféricos ${ }^{25}$.

Vários autores da comunidade acadêmica procuram explicar as altas taxas de crimes no Brasil, especialmente dos crimes dolosos contra vida, bem como a seletividade do sistema. Nesse sentido, para Tereza Caldeira (2003, p. 43), a cidadania brasileira é afetada pela reiterada violação dos direitos civis, caracterizando o que ela denominou de "democracia disjuntiva". Segundo a autora, temos no Brasil um regime democrático (democracia política) e os direitos sociais são razoavelmente legitimados. Não obstante, os aspectos civis da cidadania são continuamente violados, levando a uma concepção de corpo que ela denomina de "corpo incircunscrito", o que explicaria as altas taxas de homicídio, a violência policial e os discursos sobre a pena de morte. Faltaria à democracia brasileira estender os direitos civis a todos os cidadãos indistintamente (O'DONNELL, 2000; REZENDE DE CARVALHO, 2002).

\footnotetext{
${ }^{24}$ Waiselfiz (2006), no Mapa da violência 2006, da OEI, aponta que a maior parte dos homicídios vitima jovens (entre 15 e 24 anos) do sexo masculino e de raça negra. Os negros apresentam índice de vitimização $73,1 \%$ superior ao dos brancos na população total e $85,3 \%$ superior ao dos brancos quando considerada só a população jovem. Para Miraglia (2006), são os jovens pobres, moradores da periferia que estão morrendo, de tal forma que não é possível dizer que violência e homicídios "não dialoguem com a condição de exclusão, de vulnerabilidade, ou pobreza".

${ }^{25}$ A pesquisa revelou também que $56 \%$ das vítimas não tinham antecedentes criminais. A análise dos laudos necroscópicos indicou que $51 \%$ das vítimas apresentavam perfurações de arma de fogo nas costas e $36 \%$ na cabeça.
} 
Para Pinheiro (2000), o fracasso do Estado democrático, forjado com o fim da ditadura militar, consiste em sua incapacidade de reformar suas instituições, especialmente as de controle do crime e da violência, e na sua incapacidade de controlar os abusos de poder de seus próprios agentes. O aumento do crime e da violência, as formas privadas de fazer justiça (linchamentos, justiceiros...), as violações de direitos por agentes do Estado, a corrupção ${ }^{26}$, a falta de accountability e a impunidade vulneram o Estado Democrático de Direito e expõem as limitações do sistema de justiça criminal - composto pelo tripé polícia-justiça- prisão - que atua dentro de uma lógica coercitiva e reativa de controle do crime e da violência.

Tendo em vista que o Estado Democrático de Direito estrutura, estabiliza e ordena múltiplas relações sociais, sua violação, tanto por atores estatais como por atores privados, afeta o primado da lei (O’DONNELL, 2004). A desorganização do aparelho policial e a falência do poder público em garantir a segurança do cidadão são fatores de instabilidade e de desconfiança em relação à autoridade do Estado e das leis, afetando, a um só tempo, o equilíbrio democrático e o próprio desenvolvimento econômico do país ${ }^{27}$ (KINZO et al., 2004).

Em última análise, a crise do sistema de segurança pública revela uma fissura no modelo da moderna justiça criminal (GARLAND, 2005; WIERVIOKA, 1997).

Estado se vê fraturado naquilo que, segundo Weber, é seu instrumento mais específico: o monopólio do uso da força. O Estado moderno, para Weber, é

[...] um agrupamento de dominação que apresenta caráter institucional e que procurou (com êxito) monopolizar, nos limites do território, a violência física legítima como instrumento de domínio e que, tendo esse objetivo, reuniu nas mãos dos dirigentes os meios materiais de gestão. (WEBER, 2000, p. 22)

Ocorre que, como afirma Wiervioka (1997, p. 19), "é cada vez mais difícil para os Estados assumirem suas funções clássicas. O monopólio legítimo da violência

${ }^{26}$ O Índice de Percepções de Corrupção da Transparency International, em 2004, atribui ao Brasil nota 3,7, numa escala de 0 a 10 . Quanto mais próximo de zero, mais elevada a percepção de corrupção.

Disponível

em:

$<$ http://www.transparency.org/policy_and_research/surveys_indices/cpi/2005>.

${ }^{27}$ Para Kinzo et al. (2004, p. 54), a sensação de impunidade e de descontrole em relação à criminalidade é fator de restrição para a ampliação de investimentos no Brasil. "Segundo o 'Relatório para o Desenvolvimento Mundial - 2005, do Banco Mundial, 52,2\% das 1.642 empresas entrevistadas apontaram a criminalidade como um fator capaz de atrapalhar os negócios no país." 
física parece atomizado e, na prática, a célebre fórmula weberiana parece cada vez menos adaptada às realidades contemporâneas".

A crise do sistema de justiça criminal e a inércia frente a ela podem comprometer a institucionalidade democrática, assim como podem fazê-lo medidas reformistas adotadas na ausência de uma coalizão mínima entre os diversos atores que incidem na política. Trata-se, portanto, de uma arena política extremamente sensível, o que também contribui para explicar as dificuldades para se reformar o modelo tradicional esgotado.

Até quase o final da década de 1990, o governo federal procurou não se responsabilizar pela política de segurança pública, deixando-a a cargo das corporações policiais (exceção feita aos períodos autoritários em que, como visto, o governo federal tutelava e instrumentalizava as polícias como polícias políticas). Porém, com o quadro de crescimento acelerado da violência, tanto o governo federal como os governos municipais viram-se cada vez mais chamados à responsabilidade nessa área ${ }^{28}$. O tema, inicialmente restrito aos debates eleitorais para governos dos estados, passou a compor a agenda de debates também nas eleições para presidente da República e prefeitos, denotando, de forma inequívoca, sua entrada na agenda política.

\footnotetext{
${ }^{28}$ Pesquisa da Fecomércio (2008), realizada em nove regiões metropolitanas, sobre a opinião dos brasileiros quanto aos caminhos para a construção das políticas públicas de segurança no país, apontou a percepção da população no sentido de que todas as esferas de governo devem estar envolvidas nessa construção. Contudo, $60 \%$ dos entrevistados associaram a tarefa de combater a violência ao governo federal, $23 \%$ ao governo estadual e $14 \%$ ao governo municipal. A pesquisa também mostrou uma preferência, já presente em pesquisa realizada em 2007 e que se acentuou no ano de 2008, por ações sociais (de natureza preventiva) às ações de cunho estritamente repressivo.
} 


\section{Capítulo 4 - Comunidade da política de segurança pública: atores e preferências}

Este capítulo parte da análise de que a crise da segurança pública na sociedade contemporânea produziu diferentes paradigmas no campo do controle e da prevenção dos delitos e das violências, coexistindo novas e velhas visões sobre o tema. Aos atores tradicionais da comunidade da política de segurança somaram-se novos atores, compondo um campo de preferências plural e, por vezes, polarizado. Preferências são formadas em relação a diferentes paradigmas de políticas e, ainda que o futuro das políticas seja explicado mais pela interação entre os atores em dados contextos institucionais do que por suas preferências propriamente, compreendê-las torna possível uma análise mais adequada das estratégias e dos arranjos político-institucionais em jogo.

Sem pretender identificar de forma exaustiva todos os atores que compõem a comunidade da política de segurança pública, o presente capítulo analisa a ampliação dessa comunidade, bem como as preferências de atores que incidem sobre a política. O levantamento das preferências foi realizado por meio de um questionário aplicado a alguns atores relevantes, tornando possível identificar pontos de confluências e de polarizações. A partir dessa compreensão, são apontados fatores explicativos para o fracasso das tentativas de reforma radical do modelo da política de segurança pública.

\subsection{Diferentes paradigmas da segurança pública}

Desde o final da década de 1970, várias mudanças e rupturas vêm ocorrendo, no mundo, nos paradigmas da violência, da criminologia e das políticas criminais e de segurança. A violência adquiriu novas configurações (WIEVIORKA, 1997); o medo e a insegurança alteraram padrões de comportamento, o desenho das cidades, as relações sociais (CALDEIRA, 2003) e passaram a constituir uma nova espécie de 
matriz discursiva ${ }^{29}$; tornaram-se mais reativas e endurecidas as respostas policiais e penais.

Em praticamente todas as grandes cidades do mundo, as novas formas contemporâneas de criminalidade, as altas e crescentes estatísticas criminais e a incapacidade do sistema de justiça criminal moderno de, sozinho, conter a onda de violência, fizeram com que novas políticas e práticas de controle e prevenção do crime e da violência fossem sendo engendradas e novos atores, estatais e não estatais, passassem a incidir na política de segurança pública.

Segundo Garland (2005), enquanto as agências clássicas do sistema de justiça criminal lutam para se ajustar à realidade do delito, os atores sociais promovem suas adaptações, precauções e controles sociais rotineiros para poder conviver com a criminalidade crescente. Ao lado das respostas tradicionais, como o maior recrudescimento da repressão, criminalização de um número cada vez maior de condutas e encarceramento massivo ${ }^{30}$, outros tipos de respostas vêm sendo articuladas, visando à prevenção e ao controle de riscos.

Contemporaneamente, há um claro deslocamento "não só das instituições especializadas do Estado, mas também das racionalidades e criminologias que as fundam" (GARLAND, 2005, p. 58). Para o autor, a criminologia contemporânea divide-se em duas matrizes: as "criminologias da vida cotidiana" e a "criminologia do outro" que, além de coexistirem, comportam ambivalências. As criminologias da vida cotidiana englobam diversas teorias, como a teoria da escolha racional, das atividades habituais, do delito como oportunidade, da prevenção situacional do delito e da prevenção comunitária do delito. Para a "criminologia do outro", esse "outro" representa o perigo, é aquele que nos ameaça e que, portanto, precisa ser neutralizado, isolado, incapacitado e, por vezes, até mesmo eliminado. No debate

\footnotetext{
${ }^{29}$ As matrizes discursivas permitem a reelaborarão de sentido dos acontecimentos vividos; elas "abrem espaço para a elaboração de experiências até então silenciadas ou interpretadas de outro modo [...] devem ser, pois, entendidas como modos de abordagem da realidade, que implicam diversas atribuições de significado" (SADER, 1988, p. 142-143). Nesse sentido, Caldeira (2003) analisa o que ela denomina de "falas do crime". Segundo a autora, as falas do crime são estruturantes; elas ordenam, hierarquizam, naturalizam aquilo que é socialmente construído. Trata-se de uma narrativa fundada no preconceito que hierarquiza e inferioriza, como nesse trecho de entrevista que a autora fez com uma moradora do bairro da Mooca, em São Paulo: "A pior coisa que existe na Mooca é que o povo fica com medo. É muito crime, é muito assalto. [...] Pessoal que assalta é tudo nortista. Tudo gente favelada [...] A Mooca está empesteada [...] Na Mooca todo mundo tem medo, por isso todo mundo vai embora. A população fina vai embora e os nordestinos vão chegando, nós vamos dando espaço pra eles ..." (CALDEIRA, 2003, p. 30-31).

${ }^{30}$ Sobre o tema do encarceramento massivo, cf. Wacquant (1998) e Christie (1999).
} 
brasileiro, essas duas matrizes informam o paradigma repressivo-punitivo (criminologia do outro) e o paradigma da segurança cidadã, que enfatiza, complementarmente a uma repressão qualificada, as políticas preventivas do crime e da violência (criminologias da vida cotidiana).

Ao lado do velho paradigma repressivo-punitivo, que tem como foco combater o crime e o criminoso, emerge no campo um novo paradigma, cujo foco é a proteção do cidadão e a promoção e garantia de seus direitos, com ênfase nas ações preventivas e comunitárias. As políticas preventivas da violência fundamentam-se na ideia de que é importante atuar, antes do cometimento do delito, sobre as características do meio ambiente em que os indivíduos interagem, visando à diminuição dos fatores de risco presentes na comunidade e ao fortalecimento dos fatores de proteção ${ }^{31}$.

O campo do controle do delito - definido por Garland (2005, p. 14) como um conjunto de elementos interativos, que inclui "transformações na polícia, nas condenações judiciais, o castigo, a criminologia, a filosofia penal, as políticas penais, a segurança privada, a prevenção do delito, o tratamento das vítimas e assim sucessivamente" - tornou-se amplo, complexo e contraditório, comportando diferentes estratégias. Não há, nos dias atuais, um único modelo, uma única estratégia. $O$ novo não substitui o velho de maneira absoluta e definitiva.

Convivem diferentes paradigmas e diferentes posições. No estado de São Paulo, por exemplo, no mesmo período em que se desenvolveu um importante programa de policiamento comunitário e que se instituiu a primeira ouvidoria de polícia do país, a população prisional mais que dobrou, passando de 55.021 presos em 1994 para quase 130 mil no final de 2003 (MUNIZ; ZACCHI, 2005). Até mesmo especialistas vinculados às corporações policiais dividem opiniões. Para o coronel Jorge da Silva (2001), por exemplo, o duplo viés do modelo que ele denomina de "penalista-militarista" faz com que, até hoje, o desempenho policial seja medido por quantidade de inquéritos realizados, número de prisões e número de operações,

\footnotetext{
${ }^{31}$ Mesquita Neto (2004) define fator de risco como "aquele que aumenta a probabilidade de incidência ou os efeitos negativos de violências, mas não necessariamente determina a incidência de crimes e violências. Quanto maior a presença de fatores de risco, e menor a presença de fatores de proteção, maior a probabilidade de incidência e de efeitos negativos de crimes e violências". Fator de proteção, por sua vez, é aquele "que reduz a probabilidade de incidência ou de efeitos negativos de crimes ou violências. Quanto maior a presença de fatores de proteção e menor a presença de fatores de risco, menor a probabilidade de incidência e de efeitos negativos de crimes e violências".
} 
pouco importando as ações de prevenção e as séries históricas das taxas de criminalidade e vitimização.

Para Muniz e Zacchi (2005, p. 10-11), a evolução das políticas públicas no país, desde a década de 1990, está marcada pela polarização doutrinária entre os postulados conservadores da lei e da ordem (que, muitas vezes, admite ou justifica arbitrariedades na ação policial em nome do combate à impunidade e da proteção do "cidadão de bem") ${ }^{32}$ e uma agenda liberal que postula a garantia de direitos, a promoção de accountability e uma intervenção penal mínima, associadas à valorização da prevenção e de políticas inclusivas. Para os autores, a debilidade de ambas as posições, a primeira por ser equivocada e a segunda por ser insuficiente, ajuda a "explicar o jogo de soma zero em que se constitui o debate reformista sobre a segurança pública", até a década de 1990. Apenas na segunda metade dos anos 90, começa a surgir, segundo os autores, um novo vetor-síntese, identificado com o paradigma da segurança cidadã, que postula a complementaridade entre repressão e prevenção, defendendo o aprimoramento técnico-gerencial do sistema e das polícias e a qualificação do discurso da prevenção.

\subsection{Comunidade da política: novos e velhos atores}

Segundo a tipologia de análise interessada no ciclo deliberativo da política pública, o primeiro passo de um processo dinâmico de elaboração de uma política pública é a definição da agenda (agenda setting) ${ }^{33}$. A questão que se coloca é sobre como são definidas as agendas governamentais e por que determinados temas entram para a agenda política e outros não. Segundo o Modelo de Múltiplos Fluxos,

\footnotetext{
${ }^{32}$ Nesse sentido, por exemplo, a polícia paulista, no episódio dos ataques da facção criminosa Primeiro Comando da Capital (PCC) às forças policiais do Estado, em 2006, justificou algumas das mortes de "suspeitos", ocorridas entre os dias 12 e 20 de maio daquele ano. Segundo Mesquita (2007, p. 28), das 493 pessoas mortas por arma de fogo no período mencionado, entre agentes públicos de segurança e cidadãos comuns, 109 criminosos ou suspeitos teriam sido mortos em confronto com a polícia e 87 pessoas teriam sido mortas por assassinos não identificados pela polícia, "com indícios de execução e denúncias de participação de policiais nas execuções". Em um clima de guerra, como o que se verificou naquele episódio, alguns chegaram a se referir às mortes como "execuções preventivas", justificando, em nome da proteção do cidadão, a violação do direito à vida.

${ }^{33}$ Os cinco passos do ciclo da política são: definição da agenda, identificação de alternativas, avaliação das opções, seleção das opções, implementação e avaliação (SOUZA, 2007).
} 
formulado por Kingdon (CAPELLA, 2007), três grandes fluxos atuam concomitantemente afetando a formação e as mudanças da agenda governamental. O primeiro fluxo diz respeito aos problemas, isto é, questões que passam a ser focadas pelos formuladores de políticas e pelos participantes de um processo decisório. O segundo fluxo refere-se às alternativas e às soluções (policy stream) para os problemas, e o terceiro fluxo diz respeito a mudanças dentro do próprio governo, isto é, mudanças de pessoas em cargos estratégicos, mudanças de gestão e mudanças na composição do Congresso.

Para a compreensão do processo de formulação da política pública, analisar a comunidade da política em questão é fundamental, visto que os atores envolvidos no processo influenciam tanto a definição do que entra ou não para a agenda política, como a identificação de alternativas. Para Kingdon (CAPELLA, 2007), a comunidade da política (policy community) é composta de atores visíveis (presidente, altos postos da burocracia governamental, parlamentares, grupos de pressão, mídia) e de atores invisíveis (pesquisadores, acadêmicos, consultores, servidores públicos, analistas de um grupo de interesse). Os primeiros são influentes na definição da agenda governamental e os segundos na identificação de alternativas e de soluções para os problemas a serem enfrentados. Apesar de existir uma relativa autonomia do Estado no processo de formulação de políticas públicas, este é permeável a influências externas e internas. Além dos governos, outros segmentos, como grupos de interesses, influenciam a formulação de políticas públicas, em menor ou maior grau, a depender do tipo de política formulada e das coalizões que integram o governo (SOUZA, 2007). O objetivo desta seção é analisar como se configura a comunidade da política de segurança pública, especialmente nas duas últimas décadas, ressaltando o ingresso de novos atores e a consequente ampliação dessa comunidade.

Segundo Cano (2006, p. 137), até os anos 1970, o crime era um problema restrito às polícias. "Não existia sequer a reflexão, nem a proposta de setores progressistas que se contrapusesse à simples demanda pela ordem por parte dos grupos conservadores". O Exército ${ }^{34}$ e o poder executivo federal figuravam como

\footnotetext{
${ }^{34}$ Quanto ao poder de incidência do Exército na política de segurança pública atualmente, poderia se supor que, tendo em vista o desenho constitucional de 1988 e a vinculação da polícia militar como força auxiliar e reserva do Exército, este incidiria negativamente em relação à mudança do modelo. No entanto, seria necessário proceder a um estudo específico sobre o tema, para conhecer endogenamente suas preferências atuais. Vale ressaltar que nenhuma representação do Exército
} 
atores relevantes centrais na política de segurança pública, como ocorreu também em outros períodos autoritários. Com a democratização, as instituições policiais e os executivos estaduais voltaram a ser atores relevantes da comunidade da política, porém, até meados da década de 1990, a segurança pública ainda era tema reservado praticamente às próprias esferas policiais, cuja atuação sempre foi marcadamente repressiva, e a alguns outros setores conservadores (SOARES, 2000).

Especialmente nestas duas últimas décadas, a comunidade da política de segurança foi, aos poucos, sendo ampliada com a entrada de novos atores políticos (governo federal e municípios) e de novos atores sociais.

No que tange à entrada do governo federal como ator relevante na comunidade da política, o tema será tratado detalhadamente no capítulo 5 , no qual serão analisadas também suas agendas e preferências estratégicas. No tocante aos municípios como novos atores relevantes, por um lado é importante enfatizar que as políticas inovadoras por eles desenvolvidas, especialmente a partir do final da década de 1990, serviram de inspiração, como também se verá no capítulo 5, para a elaboração de programas federais, como o Programa Nacional de Segurança Pública com Cidadania (Pronasci). Por outro lado, é preciso ressaltar que também na nível municipal convivem velhas e novas posturas. Muitos prefeitos municipais ainda não pautaram a segurança pública em suas agendas. Não obstante, novos e relevantes atores no âmbito dos municípios já ingressaram para a comunidade da política. É o caso, por exemplo, da Frente Nacional de Prefeitos (FNP), do recémcriado Conselho Nacional dos Secretários e Gestores Municipais de Segurança Pública $^{35}$ e do Conselho Nacional das Guardas Municipais.

$\mathrm{Na}$ década de 1990, emergiu, na comunidade da política, outro ator importante. Trata-se das ouvidorias de polícia, instituições de controle externo popular da atividade policial. A primeira delas, a Ouvidoria das Polícias do Estado de São Paulo, foi instituída em 1995, no Governo Covas $^{36}$, após grande mobilização de

integrou, por exemplo, a Coordenação Nacional da Primeira Conferência Nacional de Segurança Pública, que reuniu representantes importantes nos seguimentos do poder público (gestores), dos trabalhadores e da sociedade civil atuantes na área.

${ }^{35} \mathrm{O}$ Conselho Nacional de Gestores Municipais de Segurança foi criado, por votação unânime, na $54^{\text {a }}$ Reunião Geral da Frente Nacional de Prefeitos, realizada em 16 de abril de 2009, em Brasília.

${ }^{36}$ Covas não apenas instituiu a primeira ouvidoria de polícia no Brasil, como também escolheu, para ser o primeiro Ouvidor, um sociólogo oriundo do movimento de direitos humanos e filiado a um partido político de oposição ao seu governo. 
organizações de direitos humanos. Especialmente nos seus cinco primeiros anos de existência, a Ouvidoria de São Paulo chegou a propor uma série de medidas de caráter incremental, como a instituição de uma corregedoria autônoma e independente, a reforma na Lei Orgânica da Polícia Civil e a reforma do Regulamento Disciplinar da Polícia Militar de São Paulo. Hoje, apesar de as ouvidorias ainda não estarem instituídas em todos os estados da federação e de nem todas possuírem a necessária autonomia, as 14 ouvidorias ${ }^{37}$ existentes compõem o Fórum Nacional de Ouvidores de Polícia (FNOP). No ano 2000, esse Fórum reuniu uma série de especialistas e intelectuais em torno da propositura de um Projeto de Emenda Constitucional visando a reformas estruturais das instituições policiais, que incluíam a unificação das polícias instituindo-se uma única polícia estadual, sob controle civil, e a extinção do inquérito policial.

Com o crescimento da violência, começaram também a ser criados os primeiros centros de pesquisa no Brasil voltados ao estudo do tema, como, por exemplo, o Núcleo de Estudos da Violência - NEV, vinculado à Universidade de São Paulo, criado em 1987; o Centro de Estudos de Segurança e Cidadania - CeSEC, vinculado à Universidade Cândido Mendes, criado em 2000; e o Centro de Estudos de Criminalidade e Segurança Pública - CRISP, vinculado à Universidade Federal de Minas Gerais. Os centros de estudos ingressaram no debate da segurança pública como novos atores na comunidade da política, trazendo grande contribuição não apenas por meio de pesquisas, mas também de propostas, apontando alternativas, formulando diagnósticos e, em alguns casos, construindo ações conjuntas com o poder público, de forma a qualificar a sua capacidade de intervenção.

A formação de redes de abrangência nacional (como o Fórum Brasileiro de Segurança Pública e a Rede Desarma Brasili ${ }^{38}$ ) e de articulações regionais (como o Fórum Metropolitano de Segurança Pública de São Paulo e o Consórcio Metropolitano do Recife) não apenas indica a ampliação da comunidade da política, como aponta para a capacidade de diversos atores, estatais e não estatais, se

\footnotetext{
${ }^{37}$ Possuem ouvidorias de polícia os seguintes estados: São Paulo, Bahia, Ceará, Espírito Santo, Goiás, Mato Grosso, Minas Gerais, Pará, Paraná, Pernambuco, Rio de Janeiro, Rio Grande do Norte, Rio Grande do Sul e Santa Catarina.

${ }^{38}$ A Rede Desarma Brasil foi criada em março de 2005 com o objetivo de ampliar e melhorar a campanha de entrega voluntária de armas no Brasil. A Rede agrega mais de 50 organizações de todas as regiões do país para concretizar ações pelo controle de armas.
} 
articularem para a resolução de problemas comuns, não mais circunscritos exclusivamente à esfera de competência das instituições policiais.

Outros atores sociais foram se constituindo, especialmente a partir da década de 1990, em torno da temática da segurança pública e da violência, propondo ações comunitárias, projetos preventivos e parcerias com o poder público visando à diminuição da violência. Destacam-se, entre outros, o Fórum em Defesa da Vida, criado em 1996 pela Sociedade Santos Mártires, no Jardim Ângela, em São Paulo, congregando atualmente mais de 200 entidades; o Movimento Viva Rio, criado em 1993, após as chacinas da Candelária e de Vigário Geral, ambas na cidade do Rio de Janeiro; o Instituto Sou da Paz, iniciado com uma campanha pelo desarmamento liderada por estudantes de São Paulo, em 1997; e o Instituto São Paulo contra a Violência, fundado em 1997, que teve como uma de suas principais ações a instituição do Disque Denúncia, em parceria com o Governo do Estado. Surgiram também uma série de organizações locais que mobilizam jovens de favela e moradores da periferia, como a CUFA, o AfroReggae, o Nós do Morro, entre várias outras, que atuam fortalecendo o protagonismo juvenil e "disputando" os jovens com o tráfico (Ramos, 2007). ${ }^{39}$

Segundo a postulação de Kingdon (CAPELLA, 2007), citado no início desta seção, mídia e grupos de pressão podem se constituir como atores visíveis com influência sobre a definição das agendas. A mídia pode incidir na política, não apenas por sua própria capacidade de pressão, como também fomentando a formação de outros grupos de pressão organizados na sociedade civil, frente a crimes de grande repercussão nacional. Especialmente a partir do final da década de 1980, articularam-se movimentos sociais contrapostos, uns cobrando do Estado maior repressão contra a criminalidade e maior efetividade das punições e outros recriminando a violência policial e exigindo maior controle interno e externo das instituições policiais ${ }^{40}$.

\footnotetext{
${ }^{39}$ A autora cita, ainda, movimentos de homossexuais que têm demonstrado, mais recentemente, capacidade de incidir na política, tendo conseguido, por exemplo, articular a Secretaria Nacional de Segurança Pública (SENASP) e a Secretaria Especial de Direitos Humanos (SEDH) para a realização do primeiro Seminário Nacional de Combate à Segurança Pública e Combate à Homofobia, em 2007, no Rio de Janeiro, que reuniu gestores da segurança pública, policiais dos 27 estados da federação, especialistas e ativistas de todo o país.

40 Sobre a polarização entre forças conservadoras e forças progressistas, que se tornou mais manifesta especialmente a partir da promulgação da Constituição Federal de 1988, ver Adorno, 1999.
} 
Em 1992, quando 111 presos foram executados pela polícia militar após uma rebelião no Complexo Prisional do Carandiru em São Paulo, a ação policial dividiu opiniões, havendo aqueles que a respaldavam e aqueles que a condenavam com a mesma veemência. Em 1996, logo após o assassinato de dois jovens no Bar Bodega, localizado em um bairro de classe média alta de São Paulo, nasceu o Movimento Reage São Paulo, que promoveu várias manifestações e passeatas "pedindo prisão perpétua para crimes hediondos, mais policiamento e programas para internos da FEBEM" (Jornal O Estado de S. Paulo, edição de 6/3/2001). O Movimento era apoiado por vários grupos, enquanto outros criticavam a forma como aquela articulação combatia a violência, sem ter reagido diante da notícia de tortura de suspeitos de serem os autores do crime e que, pouco depois, provaram sua inocência.

No caso das mudanças legislativas visando ao recrudescimento da lei penal, são vários os exemplos da força de grupos sociais de pressão com capacidade de influir na agenda política em conjunturas críticas, especialmente após a ocorrência de crimes que, com a ajuda da mídia, causam grande comoção nacional ${ }^{41}$. Este é o caso, por exemplo, da promulgação da Lei de Crimes Hediondos (Lei 8.072/90) e de grande parte de suas alterações posteriores, que, segundo parecer do Conselho Nacional de Política Criminal e Penitenciária de 2005, foram introduzidas em resposta às demandas de grupos sociais por leis mais severas. Por esse motivo, vários juristas se referem à Lei 8.072/90 como a "legislação do pânico" (MILANI, 2007).

A aprovação da lei de crimes hediondos se deu logo após os casos de sequestro dos empresários Abílio Diniz e Roberto Medina, em 1990. Em 1994, após outro crime brutal que chocou a opinião pública, a lei foi alterada por meio de uma emenda popular que incluiu o crime de homicídio qualificado no rol dos crimes hediondos. Segundo Piazzon (s/d), apesar do reconhecimento de penalistas de que a Lei dos Crimes Hediondos fracassou em seu principal objetivo, o de reduzir os índices dos crimes violentos, é preciso reconhecer que parte da "opinião pública

\footnotetext{
${ }^{41}$ Novamente, é preciso apontar o fato de que o futuro das políticas não pode ser explicado apenas pelos atores e por suas preferências, mas pela interação de vários atores em dados contextos institucionais. Nesse sentido, o objetivo aqui é apenas identificar atores que incidem na comunidade da política de segurança pública, pontuando cisões, polarizações e consensos nas suas preferências e agendas.
} 
pensa exatamente o contrário e reivindica penas criminais e tratamento prisional ainda mais severos".

Além dos atores já mencionados, outros compõem a comunidade da política de segurança pública. Enfocando, nesta dissertação, preferencialmente instituições e organizações de representação nacional, no que diz respeito aos atores vinculados ao poder executivo e às instituições policiais, pode-se citar, ainda, como atores políticos incidentes na política nacional de segurança pública, os conselhos nacionais, como o Conselho Nacional de Comandantes Gerais das Polícias Militares e dos Corpos de Bombeiros Militares; o Conselho Nacional de Chefes da Polícia Civil; o Conselho Nacional dos Secretários de Estado da Justiça, Cidadania, Direitos Humanos e Administração Penitenciária; o Conselho de Dirigentes dos Órgãos Periciais do Brasil e o Colégio Nacional dos Secretários de Segurança Pública. Outros atores, representando órgãos executivos da área da segurança em âmbito federal, são: a Secretaria Geral da Presidência da República, a Secretaria Especial de Direitos Humanos (SEDH), o Ministério da Justiça (SENASP, Departamento de Polícia Federal, Departamento de Polícia Rodoviária Federal).

Representando os trabalhadores da segurança pública, podem ser citados como atores relevantes as associações nacionais da polícia federal (Associação Nacional dos Delegados de Polícia Federal - ADPF, Associação Nacional dos Peritos Criminais Federais - APCF e Federação Nacional dos Policiais Federais FENAPEF); as associações nacionais da polícia militar (Associação Nacional dos Oficiais Militares Estaduais - AMEBRASIL, a Associação Nacional de Entidades Representativas de Praças Policiais e Bombeiros - ANASPRA e a Federação Nacional de Entidades de Oficiais Militares Estaduais - FENEME); as associações nacionais da polícia civil (Associação dos Delegados de Polícia do Brasil - ADEPOL e Confederação Brasileira de Trabalhadores Policiais Civis - COBRAPOL); as associações nacionais da Polícia Técnico-Científica, como a Associação Brasileira de Criminalística - ABC; a Federação Nacional dos Policiais Rodoviários Federais FENAPRF; o Sindicato dos Agentes Penitenciários Federais - SINDAPEF e o Conselho Nacional das Guardas Municipais - CNGM.

Além dos atores sociais e políticos já referidos, há ainda parlamentares e outros grupos de interesse, como o dos representantes da segurança privada e o dos representantes da indústria de armas, que, por meio de lobbies, influenciam e 
impõem constrangimentos à formação e à implementação da agenda governamental.

\subsection{Pesquisando preferências e propostas reformistas}

Para o neoinstitucionalismo histórico, preferências não podem ser atribuídas a atores sem que se indague sobre elas. É preciso reconstruí-las a partir do trabalho investigativo, de forma a não atribuir aos atores preferências estereotipadas, sustentadas por velhas crenças e pelo senso comum. As preferências dos atores, nesta dissertação, foram identificadas por meio da aplicação de questionários, pela análise de documentos institucionais e da literatura específica. O objetivo desta seção é verificar como se configura o campo do ponto de vista das preferências dos atores da comunidade da política de segurança pública, ressaltando que preferências específicas do poder executivo federal serão analisadas no capítulo 5.

Com vistas a verificar as agendas dos atores, suas opiniões sobre a importância da participação social na gestão da segurança pública, sobre o papel dos municípios na segurança, bem como suas preferências quanto às reformas no modelo da política, elaborou-se um questionário (Anexo B), que, por ocasião da Primeira Conferência Nacional de Segurança Pública, realizada entre os dias 27 e 30 de agosto de 2009, foi respondido por 25 organizações integrantes da CON Comissão Organizadora Nacional da 1a. CONSEG $^{42}$. Essa comissão era composta por 36 organizações representativas de gestores e outras instituições do poder público, de trabalhadores e de organizações da sociedade civil atuantes na área da segurança pública. Das 17 representações de trabalhadores, 12 responderam ao questionário $^{43}$ e das 13 representações da sociedade civil, nove também o

\footnotetext{
${ }^{42}$ A relação completa dos membros da CON e a sistematização de todas as respostas dadas quando da aplicação do questionário, encontram-se nos Anexo A e C, respectivamente.

${ }^{43}$ Representando o segmento dos trabalhadores, responderam ao questionário: AMEBRASIL, ANASPRA, FENEME, ADEPOL, COBRAPOL, ABC, FENAPRF, ADPF, FENAPEF, SINDAPEF, CNGM, FNOP.
} 
responderam ${ }^{44}$. O questionário foi respondido, ainda, por quatro atores representantes do segmento dos gestores ${ }^{45}$.

$O$ fato de muitos dos atores respondentes representarem instituições nacionais que congregam várias outras instituições organizadas nos estados e, a depender do ator, nos municípios, faz com que se tenha, para o objetivo aqui proposto, uma amostra bastante expressiva do ponto de vista da representatividade e legitimidade dos atores e de sua capacidade de incidir na política ${ }^{46}$.

Para a análise das respostas, foram utilizados dois tipos de clivagem. Um deles agrupa os atores da seguinte forma: atores sociais (FENDH, ISPCV, FBSP, Instituto Sou da Paz, Viva Rio, Rede Desarma Brasil, Rede F4/ Observatório de Favelas $^{47}$, Grande Oriente do Brasil, RENAESP ${ }^{48}$ ); atores vinculados ao âmbito municipal (FNP, GGI-Ms ${ }^{49}, \mathrm{CMGM}$ ); atores vinculados à polícia militar (CNCG, AMEBRASIL, FENEME, ANASPRA); atores vinculados à polícia civil (ADEPOL e COBRAPOL); atores vinculados às polícias federais (FENAPEF, ADPF, FENAPRF)

\footnotetext{
${ }^{44}$ Representando o segmento da sociedade civil, responderam ao questionário: FENDH, ISPCV, FBSP, Instituto Sou da Paz, Viva Rio, Rede Desarma Brasil, Rede F4, Grande Oriente do Brasil e RENAESP.

${ }^{45}$ São eles: FNP, GGI-Ms, CONSESP (SSP-Amazonas) e CNCG.

${ }^{46}$ Apenas para elucidar a representatividade das organizações de âmbito nacional, citamos os exemplos que seguem. A Associação Nacional dos Oficiais Militares Estaduais (AMEBRASIL) congrega, em nível nacional, todos os oficiais das polícias militares e dos corpos de bombeiros militares. A Associação Nacional dos Delegados de Polícia Federal (APDF) é a primeira entidade de classe representativa dos delegados de polícia federal no Brasil, contando cerca de 1.500 associados, tendo diretorias regionais em todos os estados e no Distrito Federal. A Federação Nacional dos Policiais Federais (FENAPEF) agrega sindicatos de todos os estados e do Distrito Federal. A Associação Nacional dos Peritos Criminais Federais (APCF) tem mais de mil associados em todo o país. A Federação Nacional de Entidades de Oficiais Militares Estaduais (FENEME) representa nacionalmente as entidades de oficiais de todos os estados. A Associação dos Delegados de Polícia do Brasil (ADEPOL) congrega todos os delegados de polícia de carreira do país e a Confederação Brasileira de Trabalhadores Policiais Civis (COBRAPOL) é órgão confederativo representativo das federações e sindicatos de trabalhadores policiais civis de quase todos os estados da federação e do Distrito Federal.

${ }^{47}$ O F4 é o Favela a Quatro, reunião informal de quatro organizações criadas por moradores de comunidades populares: a CUFA (Central Única de Favelas), o AfroReggae; o Nós do Morro e o Observatório de Favelas. As quatro instituições têm como objetivo comum a promoção de ações conjuntas com vistas à redução da violência contra crianças, adolescentes e jovens no Rio de Janeiro. A pessoa que respondeu ao questionário assinalou que o fez representando o Observatório de Favelas.

${ }^{48}$ A RENAESP inclui-se entre os atores sociais porque é uma representação das instituições de ensino superior vinculadas à rede do Ministério da Justiça.

${ }^{49} \mathrm{O}$ conjunto dos Gabinetes de Gestão Integrada Municipais - GGI-Ms não representa uma instituição formal. Todos os municípios que aderiram ao Pronasci, no Brasil, pouco mais de cem municípios à época da conferência, assumem a obrigação de constituir esses gabinetes. Os GGI-Ms, que serão melhor estudados no capítulo 5 , apesar de compostos por representantes dos três níveis de poder, são presididos pelos prefeitos municipais e, para efeito de análise desta pesquisa, serão entendidos como um dos atores vinculados ao âmbito municipal.
} 
e outros (FNOP, SSP-AM/CONSESP ${ }^{50}$, ABC e SINDAPEF). O outro tipo, mais simplificado, considera, de um lado, os atores sociais e, de outro, todos os demais atores compreendendo tanto os trabalhadores como os gestores da área da segurança pública.

Inicialmente, procurou-se reconstruir a agenda dos diferentes atores, formulando-lhes a seguinte questão: "Qual é a agenda de propostas de sua instituição para a segurança pública?". As respostas, retratadas integralmente no Quadro 1, abaixo, mostram que, de forma geral, as agendas dos atores sociais refletem as atividades-fim de cada instituição, pautando, ainda, questões como participação e controle social, respeito aos direitos humanos, desarmamento e, em alguns casos, propostas reformistas, como a desmilitarização das polícias militares. Já as agendas dos demais atores, representantes dos trabalhadores e gestores da segurança pública, pautam majoritariamente questões corporativas e relacionadas à gestão. Em alguns casos, são apontadas pautas reformistas, indicando a propositura do ciclo completo, a desmilitarização ou a extinção ou fortalecimento do inquérito policial. É preciso, no entanto, ressaltar que o questionário foi aplicado no curso da 1‥ CONSEG, em que as questões referentes a esses tipos de mudanças polarizavam o debate de ideias. Vale notar que, apesar dessa caracterização geral, os atores não têm agendas que se sobreponham completamente, mesmo quando estão vinculados a uma mesma instituição.

\footnotetext{
${ }^{50}$ O secretário de segurança pública do Amazonas, representante na CON do Conselho Nacional de Secretários Estaduais de Segurança Pública - CONSESP, manifestou verbalmente que as opiniões expressas em todo o questionário eram pessoais, uma vez que não poderia falar pelo Conselho sem consultá-lo previamente.
} 


\section{Quadro 1}

\section{Agenda de propostas para a segurança pública}

\begin{tabular}{|c|c|c|}
\hline & ATORES & PROPOSTAS \\
\hline \multirow{4}{*}{ 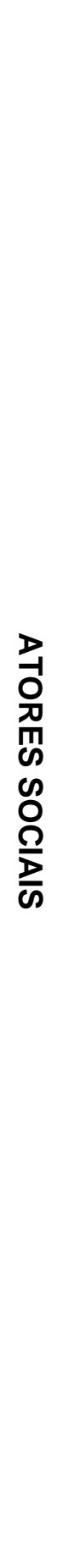 } & $\begin{array}{c}\text { FÓRUM DE } \\
\text { ENTIDADES } \\
\text { NACIONAIS DE } \\
\text { DIREITOS } \\
\text { HUMANOS }\end{array}$ & $\begin{array}{l}\text { Efetiva implementação da Lei Maria da Penha; } \\
\text { Fim do extermínio da juventude negra; } \\
\text { Combate à intolerância religiosa, às religiões de matrizes } \\
\text { africanas; } \\
\text { Desmilitarização das Polícias Militares; } \\
\text { Respeito à diversidade (LGBT); } \\
\text { Respeito aos movimentos sociais. }\end{array}$ \\
\hline & $\begin{array}{c}\text { INSTITUTO SÃO } \\
\text { PAULO CONTRA } \\
\text { A VIOLÊNCIA }\end{array}$ & $\begin{array}{l}\text { Evitar ações de terrorismo urbano; } \\
\text { Enfraquecer o crime organizado dentro e fora das prisões; } \\
\text { Reduzir crimes e violências com grande repercussão na } \\
\text { mídia (rebeliões, sequestros, arrastões); } \\
\text { Intensificar o policiamento ostensivo, investigação criminal } \\
\text { em áreas com presença do crime organizado e maior risco } \\
\text { de violências; } \\
\text { Prisão de lideranças do crime organizado e de autores de } \\
\text { ações de terrorismo e de crimes que resultem em morte; } \\
\text { Promover a segurança do cidadão, com participação social } \\
\text { no desenvolvimento das políticas. }\end{array}$ \\
\hline & $\begin{array}{c}\text { FÓRUM } \\
\text { BRASILEIRO DE } \\
\text { SEGURANÇA } \\
\text { PÚBLICA }\end{array}$ & $\begin{array}{l}\text { Promoção da paz, da cidadania e dos direitos humanos; } \\
\text { Intercâmbio e difusão de ideias e conhecimentos para o } \\
\text { aperfeiçoamento da organização policial, das práticas } \\
\text { policiais e dos serviços de segurança pública; } \\
\text { Primado dos direitos humanos, em particular das garantias } \\
\text { plenas da integridade física e do devido processo legal; } \\
\text { Transparência, participação e controle social; } \\
\text { Proatividade e ênfase preventiva como estratégias } \\
\text { primordiais; } \\
\text { Coprodução, multissetorialidade, integração } \\
\text { interinstitucional (polícias, justiça penal, órgãos públicos } \\
\text { sociais e urbanos, universidades, sociedade civil); } \\
\text { Eficiência, efetividade e eficácia na redução de índices de } \\
\text { criminalidade, violência e insegurança; } \\
\text { Qualidade na prestação de serviços policiais e de } \\
\text { segurança pública, especialmente no atendimento das } \\
\text { vitimas da violência; } \\
\text { Valorização do policial como profissional e servidor público. }\end{array}$ \\
\hline & $\begin{array}{l}\text { INSTITUTO SOU } \\
\text { DA PAZ }\end{array}$ & $\begin{array}{l}\text { Segurança pública como direito social a ser garantido a } \\
\text { todas as pessoas para que tenham liberdade e convivência }\end{array}$ \\
\hline
\end{tabular}




\begin{tabular}{|c|c|c|}
\hline & $\begin{array}{c}\text { INSTITUTO SOU } \\
\text { DA PAZ } \\
\text { (cont.) }\end{array}$ & $\begin{array}{l}\text { pacífica; } \\
\text { Segurança pública provida em todas as esferas de governo, } \\
\text { de forma integrada e com participação social; } \\
\text { Aliar prevenção e repressão qualificada; } \\
\text { Atuar em cinco áreas: controle de armas; juventude e } \\
\text { prevenção da violência; gestão local de segurança; polícia; } \\
\text { e cultura e valores. }\end{array}$ \\
\hline & VIVA RIO & $\begin{array}{l}\text { Atuar em três grandes eixos: juventude, polícias e armas, } \\
\text { com desenvolvimento de projetos no Brasil e no Exterior; } \\
\text { Foco nos temas sobre drogas; segurança municipal, } \\
\text { formação de guardas e polícias, operações de paz e } \\
\text { juventude envolvida com o crime. }\end{array}$ \\
\hline & $\begin{array}{c}\text { REDE DESARMA } \\
\text { BRASIL }\end{array}$ & $\begin{array}{l}\text { Controle de armas; } \\
\text { Planos de segurança pública municipais; } \\
\text { Implementação do Estatuto do Desarmamento. }\end{array}$ \\
\hline & $\begin{array}{c}\text { REDE F4 } \\
\text { (Observatório de } \\
\text { Favelas) }\end{array}$ & $\begin{array}{l}\text { Valorização da vida como princípio fundamental das } \\
\text { políticas de segurança pública; } \\
\text { Ampliação e fortalecimento dos canais de participação } \\
\text { social reconhecendo os espaços populares como partes } \\
\text { integrantes da cidade; } \\
\text { Fortalecimento dos mecanismos de controle externo da } \\
\text { atividade policial; } \\
\text { Reformas estruturais no modelo de polícia; } \\
\text { Desmilitarização; } \\
\text { Investimento em ações voltadas para a redução da } \\
\text { letalidade da ação policial; } \\
\text { Fortalecer a implementação de uma política de } \\
\text { desarmamento; } \\
\text { Criação de uma política nacional com foco na redução de } \\
\text { homicídios de adolescentes e jovens. }\end{array}$ \\
\hline & $\begin{array}{l}\text { GRANDE } \\
\text { ORIENTE DO } \\
\text { BRASIL }\end{array}$ & $\begin{array}{l}\text { Trabalhar com a juventude na prevenção e rejeição das } \\
\text { drogas; } \\
\text { Trabalhar a cultura de paz nas escolas; } \\
\text { Trabalhar a campanha do desarmamento - controle sobre } \\
\text { as armas e munições. }\end{array}$ \\
\hline & RENAESP & $\begin{array}{l}\text { Qualificação para todos os níveis hierárquicos das } \\
\text { corporações policiais; } \\
\text { Formação qualificada na graduação, mestrado e doutorado; } \\
\text { Ações de prevenção da violência, justiça e direitos } \\
\text { humanos. }\end{array}$ \\
\hline 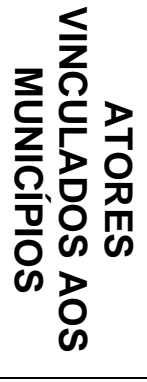 & $\begin{array}{l}\text { FRENTE } \\
\text { NACIONAL DE } \\
\text { PREFEITOS }\end{array}$ & $\begin{array}{l}\text { Articulação federativa, assegurando-se a participação social } \\
\text { na construção da política de segurança pública; } \\
\text { Consolidação do Pronasci como política de Estado; } \\
\text { Rearticulação do CONASP, conselhos estaduais e } \\
\text { municipais, garantindo a participação de gestores, } \\
\text { trabalhadores e da sociedade civil; } \\
\text { Implementação de políticas públicas de prevenção, } \\
\text { fortalecendo o papel dos municípios. }\end{array}$ \\
\hline
\end{tabular}




\begin{tabular}{|c|c|c|}
\hline & $\begin{array}{l}\text { GABINETES DE } \\
\text { GESTÃO } \\
\text { INTEGRADA - } \\
\text { MUNICIPAIS }\end{array}$ & $\begin{array}{l}\text { Estabelecer política de segurança urbana no município; } \\
\text { Implantar projetos do Pronasci; } \\
\text { Estabelecer novo marco legal para as guardas municipais; } \\
\text { Regulamentar as guardas municipais como polícias } \\
\text { municipais preventivas e comunitárias; } \\
\text { Contribuir para o debate de reformulação das estruturas } \\
\text { policiais vigentes. }\end{array}$ \\
\hline & $\begin{array}{l}\text { CONSELHO } \\
\text { NACIONAL DAS } \\
\text { GUARDAS } \\
\text { MUNICIPAIS }\end{array}$ & $\begin{array}{l}\text { Segurança pública mais humanizada; } \\
\text { Possibilitar que a matéria saia do campo de discussão } \\
\text { exclusivo dos membros das instituições policiais, } \\
\text { envolvendo a sociedade civil. }\end{array}$ \\
\hline \multirow{4}{*}{ 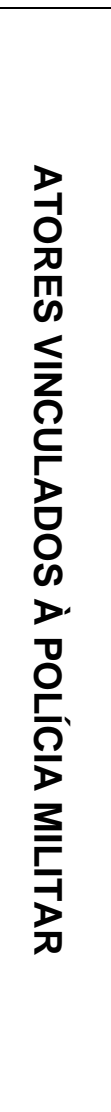 } & $\begin{array}{l}\text { CONSELHO } \\
\text { NACIONAL DOS } \\
\text { COMANDANTES } \\
\text { GERAIS DAS } \\
\text { PMS E CORPOS } \\
\text { DE BOMBEIROS } \\
\text { MILITARES }\end{array}$ & $\begin{array}{l}\text { Valorização dos profissionais de segurança pública; } \\
\text { Ciclo completo de polícia; } \\
\text { Manutenção das polícias e Corpos de Bombeiros com } \\
\text { caráter militar; } \\
\text { Zelar pela manutenção dos direitos sociais das instituições } \\
\text { policiais, adquiridos ao longo do tempo. }\end{array}$ \\
\hline & AMEBRASIL & $\begin{array}{l}\text { Segurança pública como política de Estado; } \\
\text { Definição de percentual orçamentário mínimo, federal, } \\
\text { estadual e municipal, para a segurança pública; } \\
\text { Ciclo completo de polícia para as instituições de segurança } \\
\text { pública. }\end{array}$ \\
\hline & ANASPRA & $\begin{array}{l}\text { Ciclo completo de polícia; } \\
\text { Previsão constitucional de destinação de recursos para a } \\
\text { segurança pública; } \\
\text { Financiamento exclusivo pelos entes federados, estados e } \\
\text { União; } \\
\text { Reforma da legislação disciplinar e penal militar; } \\
\text { Fim do IPM; } \\
\text { Criação do Ministério da Segurança Pública. }\end{array}$ \\
\hline & FENEME & $\begin{array}{l}\text { Ciclo completo de polícia para todas as polícias; } \\
\text { Piso nacional de salários para a segurança pública; } \\
\text { Verba carimbada do orçamento para a segurança pública. }\end{array}$ \\
\hline \multirow{2}{*}{ 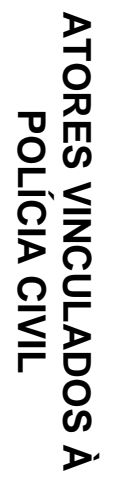 } & ADEPOL & $\begin{array}{l}\text { Regulamentação do art. 144, da CF; } \\
\text { Fortalecimento do Inquérito Policial; } \\
\text { Investimentos com qualificação e salários dos policiais; } \\
\text { Autonomia administrativa e financeira para as polícias civis; } \\
\text { Aprovação de uma Lei Orgânica para as polícias civis e } \\
\text { polícia federal. }\end{array}$ \\
\hline & COBRAPOL & $\begin{array}{l}\text { Ministério da Segurança Pública; } \\
\text { Desmilitarização; } \\
\text { Federalização parcial; } \\
\text { Criação de carreira policial única nas duas esferas. }\end{array}$ \\
\hline
\end{tabular}




\begin{tabular}{|c|c|c|}
\hline 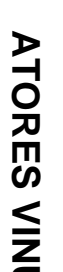 & FENAPRF & $\begin{array}{l}\text { Valorização do policial; } \\
\text { Aumento do efetivo; } \\
\text { Combate à exploração sexual infanto-juvenil; } \\
\text { Preservação do meio-ambiente; } \\
\text { Respeito aos direitos humanos; } \\
\text { Combate efetivo à criminalidade. }\end{array}$ \\
\hline 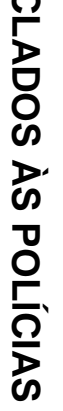 & ADPF & $\begin{array}{l}\text { Autonomia funcional e administrativa das instituições } \\
\text { policiais; } \\
\text { Lei orgânica com um regime de prerrogativas funcionais } \\
\text { que assegurem a independência investigativa; } \\
\text { Resgate constitucional dos delegados de polícia como } \\
\text { carreira jurídica e típica do Estado; } \\
\text { Política de Valorização do sistema de segurança pública no } \\
\text { tocante aos direitos e benefícios na área de recursos } \\
\text { humanos. }\end{array}$ \\
\hline 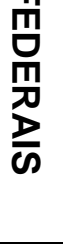 & FENAPEF & $\begin{array}{l}\text { Cargo único; } \\
\text { Extinção do Inquérito Policial; } \\
\text { Fim do Indiciamento na esfera policial; } \\
\text { Democratização no Departamento da Polícia Federal; } \\
\text { Polícia da sociedade e não de governo. }\end{array}$ \\
\hline \multirow{4}{*}{$\begin{array}{l}\stackrel{\bigcirc}{\subseteq} \\
\stackrel{1}{\not \supset} \\
\text { œ }\end{array}$} & $\begin{array}{l}\text { FÓRUM } \\
\text { NACIONAL DE } \\
\text { OUVIDORES DE } \\
\text { POLÍCIA }\end{array}$ & $\begin{array}{l}\text { Sistema Único de Segurança; } \\
\text { Criação de Ouvidoria das Polícias Federais; } \\
\text { Criação de Ouvidorias de Polícia em todos os estados; } \\
\text { Autonomia das Ouvidorias e indicação dos ouvidores pela } \\
\text { sociedade civil; } \\
\text { Integração das Ouvidorias ao SUSP. }\end{array}$ \\
\hline & $\begin{array}{l}\text { SECRETÁRIO } \\
\text { DE SEGURANÇA } \\
\text { PÚBLICA DO } \\
\text { AMAZONAS } \\
\text { (CONSESP) }\end{array}$ & $\begin{array}{l}\text { Percentual fixo para aplicação na segurança pública (verba } \\
\text { carimbada); } \\
\text { Fortalecimento das ouvidorias, corregedorias, instituições } \\
\text { de ensino e inteligência policial. }\end{array}$ \\
\hline & $A B C$ & $\begin{array}{l}\text { Autonomia da perícia oficial criminal; } \\
\text { Respeito à cidadania e aos direitos humanos; } \\
\text { Valorização dos profissionais da área de segurança; } \\
\text { Transversalidade da segurança pública; } \\
\text { Mudanças na legislação, buscando o fortalecimento das } \\
\text { instituições. }\end{array}$ \\
\hline & SINDAPEF & $\begin{array}{l}\text { Aprovação da PEC 308/2004 que cria a Polícia Penal, no } \\
\text { âmbito das unidades federais e estaduais; } \\
\text { Valorização do servidor da área da segurança; } \\
\text { Reestruturação do sistema penitenciário; } \\
\text { Criação de um sistema penal único. }\end{array}$ \\
\hline
\end{tabular}


Em relação ao modo como os atores avaliam a participação social na política de segurança pública, perguntou-se: "Para a sua instituição, a participação social na política de segurança pública é: muito importante, relativamente importante, indesejável ou indiferente?" Todos os respondentes afirmaram ser muito importante a participação social nessa política, à exceção do representante da FENEME, para quem ela é relativamente importante (Quadro 4, do Anexo C). A pesquisa, porém, não permite avaliar o entendimento de cada um dos atores acerca do conteúdo dessa participação ou de como ela deva ocorrer ${ }^{51}$.

No que diz respeito ao papel dos municípios na política de segurança pública, todos os atores, sem exceção, responderam positivamente à seguinte pergunta: "Para sua instituição, os municípios devem ter alguma atribuição específica dentro do sistema de segurança pública?". Em seguida, perguntou-se qual seria essa atribuição. Conforme se verifica no Quadro 3 do Anexo C, 13 dos respondentes mencionaram expressamente o foco preventivo da atuação municipal por meio da implementação de políticas sociais e/ou por meio de suas guardas (entre eles estão os três atores vinculados ao âmbito municipal, seis dos nove atores sociais, um vinculado à polícia civil, um às polícias federais e dois vinculados à polícia militar. Esses últimos são a ANASPRA e a FENEME, com a diferença de que a primeira ressaltou a importância de que os municípios não financiem ou paguem custos da segurança "para evitar interferência política danosa à segurança pública", enquanto a FENEME afirmou que a contribuição municipal deve se dar "principalmente com recursos"). Os demais atores responderam de forma variada, em geral apenas reafirmando a importância da integração dos municípios no sistema de segurança pública, a importância da construção de planos municipais ou, ainda, mencionando a guarda municipal, sem qualificar o tipo de atuação.

Sobre medidas gerenciais ou de gestão voltadas para a maior eficiência do sistema de segurança pública, perguntou-se: "Há alguma(s) medida(s) gerencial(ais) ou de gestão que sua instituição considera relevante para uma maior eficiência das instituições de segurança Pública? Quais?" Pelos atores sociais foram citadas, entre outras, uma maior integração entre as instituições de segurança pública e a

\footnotetext{
${ }^{51}$ Provavelmente, as respostas seriam mais variadas se a pergunta se referisse também ao tipo de participação que se reputa importante, isto é, participação social no compartilhamento da gestão, no controle externo, na implementação de políticas preventivas, no policiamento comunitário e assim por diante.
} 
necessidade de qualificar a relação destas com a sociedade civil, além de um maior controle social. Os atores vinculados à polícia militar (CNCG, AMEBRASIL, FENEME, ANASPRA) mencionaram medidas como o fim das ingerências políticas, lista tríplice para gestores, maior liberdade para tomar decisões e adoção do ciclo completo da atividade policial. Os atores vinculados à polícia civil (ADEPOL, COBRAPOL) mencionaram autonomia administrativa e financeira e a criação de conselhos nas três esferas de governo. Os atores vinculados às policias federais (FENAPRF, ADPF e FENAPEF) mencionaram maior capacitação, autonomia administrativa e financeira, adoção de indicadores de desempenho, lei orgânica, carreira única e desburocratização do inquérito policial. O representante do CONSESP (respondendo como secretário de segurança pública) mencionou maior investimento em formação, inteligência e instalações. Foram citados, ainda, maior investimento na valorização do trabalhador $(A B C)$ e possibilidade de ascensão do servidor ao topo da carreira (SINDAPEF). As respostas completas encontram-se no Quadro 5 do Anexo C.

Quanto às reformas constitucionais no modelo de segurança pública, inicialmente perguntou-se como cada um dos atores avalia sua importância, classificada em reformas essenciais, importantes, indesejáveis e indiferentes. Conforme mostra o Quadro 2 do Anexo C, a maior parte dos respondentes (13) considera as reformas constitucionais essenciais, oito as consideram importantes, dois (FENEME e ADEPOL) consideram as reformas constitucionais indesejáveis e um dos atores (ADPF) considera-as indiferentes. Quando se analisam as respostas dadas pelos grupos de atores, percebe-se que os atores da sociedade civil se dividem entre os que consideram as reformas essenciais e os que as consideram importantes. Para dois dos três atores vinculados aos municípios, as reformas são essenciais e, para o terceiro, elas são importantes. As reformas são essenciais para apenas um dos quatro atores vinculados à policia militar, para outros dois elas são importantes e para outro são indesejáveis. Os atores vinculados à polícia civil também estão divididos, um deles as considera essenciais e o outro indesejáveis. Quase a totalidade dos atores vinculados à policia federal, bem como do grupo de "outros" atores consideram as reformas essenciais, à exceção da ADPF que considera as reformas constitucionais indiferentes e o representante do COMSESP que as considera importantes. O resultado expressa que, apesar de existirem 
polarizações, especialmente de atores vinculados às polícias militar e civil, há uma preferência majoritária por algum tipo de mudança no modelo da política.

Sobre o tipo esperado de mudança constitucional no modelo da segurança pública, perguntou-se: "Há alguma proposta de mudança constitucional no modelo do sistema de segurança pública que sua instituição tenha proposto ou defenda?". Seguiram-se, para assinalar "sim" ou "não", as seguintes alternativas: "a) Unificação das polícias civil e militar; b) Desvinculação da polícia militar como força auxiliar e reserva do Exército; c) Desconstitucionalização do artigo 144 da CF para que cada estado da federação possa escolher a polícia que deseja; d) Ampliação das atribuições das guardas municipais. Se sim, para que tenham quais atribuições?; e) Atribuição do ciclo completo da atividade policial a todas as instituições policiais; f) Outra". Foram relacionadas as propostas de mudanças estruturais mais recorrentes na literatura específica, introduzindo a possibilidade de que o respondente indicasse alguma outra. Dada a relevância do quadro que sintetiza as repostas dadas, ele segue abaixo reproduzido: 
Sobre proposta de mudança constitucional no modelo do Sistema de Segurança Pública

\begin{tabular}{|c|c|c|c|c|c|c|c|}
\hline & ATORES & $\begin{array}{c}\text { Unificação } \\
\text { das } \\
\text { polícias }\end{array}$ & $\begin{array}{c}\text { Desvinculação } \\
\text { das PMs do } \\
\text { Exército }\end{array}$ & $\begin{array}{l}\text { Desconstitucionali- } \\
\text { zação do art. } 144\end{array}$ & $\begin{array}{c}\text { Ampliação atribuições das } \\
\text { Guardas }\end{array}$ & $\begin{array}{l}\text { Ciclo completo da } \\
\text { atividade policial }\end{array}$ & Outra \\
\hline \multirow{9}{*}{ 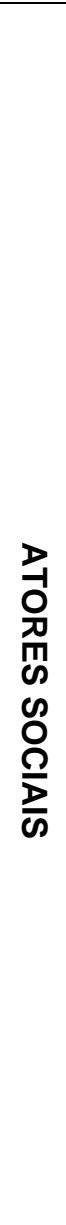 } & FENDH & Sim & Sim & Não & Não & $\begin{array}{l}\text { Sem posicionamento } \\
\text { definido sobre o tema. }\end{array}$ & \\
\hline & ISPCV & $\mathrm{N} / \mathrm{R}$ & $N / R$ & $N / R$ & $\mathrm{~N} / \mathrm{R}$ & $\mathrm{N} / \mathrm{R}$ & $\begin{array}{c}\text { Propor amplo } \\
\text { debate para } \\
\text { discussão da } \\
\text { questão. }\end{array}$ \\
\hline & FBSP $^{*}$ & $\mathrm{~N} / \mathrm{R}$ & $\mathrm{N} / \mathrm{R}$ & $N / R$ & $\mathrm{~N} / \mathrm{R}$ & $N / R$ & \\
\hline & $\begin{array}{c}\text { Instituto } \\
\text { Sou da Paz }\end{array}$ & $\mathrm{N} / \mathrm{R}$ & Sim & $N / R$ & $\begin{array}{l}\text { Não. A discussão deve ser feita de } \\
\text { baixo para cima, a partir das } \\
\text { atividades que as GMs já } \\
\text { desenvolvem na prática e de forma } \\
\text { integrada com as atividades das } \\
\text { outras instituições. }\end{array}$ & $N / R$ & \\
\hline & Viva Rio & Não & Sim & Sim & $\begin{array}{l}\text { Sim. Ampliação para atuação em } \\
\text { prevenção. }\end{array}$ & $\begin{array}{c}\text { Ciclo completo necessita } \\
\text { de um maior debate } \\
\text { envolvendo diferentes } \\
\text { atores. }\end{array}$ & \\
\hline & $\begin{array}{c}\text { Rede } \\
\text { Desarma } \\
\text { Brasil }\end{array}$ & $N / R$ & Sim & $N / R$ & $\mathrm{~N} / \mathrm{R}$ & Sim & \\
\hline & Rede F4** & $\mathrm{N} / \mathrm{R}$ & Sim & $\mathrm{N} / \mathrm{R}$ & $\mathrm{N} / \mathrm{R}$ & $\mathrm{N} / \mathrm{R}$ & \\
\hline & $\begin{array}{c}\text { Grande } \\
\text { Oriente do } \\
\text { Brasil }\end{array}$ & Não & Não & Não & $\begin{array}{c}\text { Sim. Para trabalhos } \\
\text { essencialmente comunitários. }\end{array}$ & Sim & \\
\hline & RENAESP & Sim & Sim & “????” & Sim & Sim & \\
\hline
\end{tabular}




\begin{tabular}{|c|c|c|c|c|c|c|c|}
\hline & ATORES & $\begin{array}{l}\text { Unificação } \\
\text { das } \\
\text { polícias }\end{array}$ & $\begin{array}{l}\text { Desvinculação } \\
\text { das PMs do } \\
\text { Exército }\end{array}$ & $\begin{array}{l}\text { Desconstitucionali- } \\
\text { zação do art. } 144\end{array}$ & $\begin{array}{c}\text { Ampliação atribuições das } \\
\text { Guardas }\end{array}$ & $\begin{array}{l}\text { Ciclo completo da } \\
\text { atividade policial }\end{array}$ & Outra \\
\hline \multirow{3}{*}{ 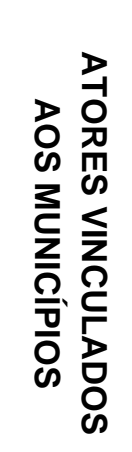 } & $\mathrm{FNP}^{* \star *}$ & Sim & Sim & Não & Sim & Sim & \\
\hline & GGI-Ms & $N / R$ & Sim & Sim & $\begin{array}{c}\text { Sim. Polícia Municipal } \\
\text { preventiva e comunitária. }\end{array}$ & Sim & $\begin{array}{l}\text { Tornar o } \\
\text { SUSP um } \\
\text { sistema } \\
\text { constitucional }\end{array}$ \\
\hline & CNGM & Não & Sim & Não & Sim & Não & \\
\hline \multirow{4}{*}{ 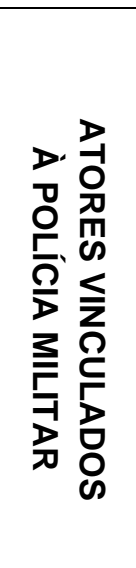 } & CNCG & Não & Não & Não & $\begin{array}{l}\text { Busca de poder de polícia para } \\
\text { as GMs deve ser respeitada, } \\
\text { mas sem intervenção e invasão } \\
\text { nas competências das PMs. }\end{array}$ & Sim & \\
\hline & AMEBRASIL & Não & Sim & Não & $N / R$ & Sim & \\
\hline & ANASPRA & Não & Sim & Não & Não & Sim & \\
\hline & FENEME & Não & Não & Não & Não & Sim & \\
\hline \multirow{2}{*}{ 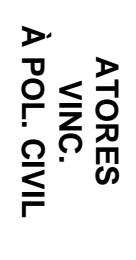 } & ADEPOL & Não & Sim & Não & Sim & Não & \\
\hline & COBRAPOL & $N / R$ & Sim & Não & $\begin{array}{l}\text { Sim. Atribuições de polícia } \\
\text { ostensiva e comunitária } \\
\text { (prevenção). }\end{array}$ & Não & \\
\hline
\end{tabular}




\begin{tabular}{|c|c|c|c|c|c|c|c|}
\hline & ATORES & $\begin{array}{l}\text { Unificação } \\
\text { das } \\
\text { polícias }\end{array}$ & $\begin{array}{c}\text { Desvinculação } \\
\text { das PMs do } \\
\text { Exército }\end{array}$ & $\begin{array}{l}\text { Desconstitucionali- } \\
\text { zação do art. } 144\end{array}$ & $\begin{array}{c}\text { Ampliação atribuições das } \\
\text { Guardas }\end{array}$ & $\begin{array}{l}\text { Ciclo completo da } \\
\text { atividade policial }\end{array}$ & Outra \\
\hline \multirow{3}{*}{ 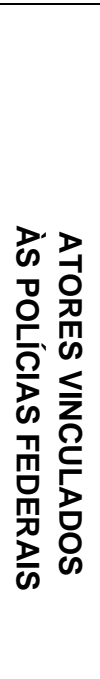 } & FENAPRF & Não & Não & Não & Não & Sim & \\
\hline & ADPF & Não & Sim & Não & $\begin{array}{l}\text { Sim. Assumir parte das atribuições } \\
\text { das PMs nos municípios, em rel. } \\
\text { aos delitos de pequeno potencial } \\
\text { ofensivo, contravenções penais e } \\
\text { ilícitos de natureza administrativa. }\end{array}$ & Não & $\begin{array}{l}\text { Resgate do } \\
\text { reconhecimento } \\
\text { constitucional do } \\
\text { Delegado de } \\
\text { Polícia como } \\
\text { carreira jurídica. }\end{array}$ \\
\hline & FENAPEF & Sim & Sim & Sim & $\begin{array}{l}\text { Sim. Formalizar as ocorrências } \\
\text { através de procedimento } \\
\text { administrativo ágil ou TC, } \\
\text { encaminhando diretamente ao MP, } \\
\text { para judicialização, para resposta } \\
\text { ágil aos anseios da sociedade. }\end{array}$ & Sim & $\begin{array}{c}\text { Carreira única, } \\
\text { com início, meio } \\
\text { e fim, entrando } \\
\text { na base, } \\
\text { podendo, } \\
\text { através da } \\
\text { capacitação, } \\
\text { chegar ao topo. }\end{array}$ \\
\hline \multirow{4}{*}{ 읃 } & FNOP & $\mathrm{N} / \mathrm{R}$ & Sim & Não & "Não temos posição definida." & $\mathrm{N} / \mathrm{R}$ & \\
\hline & $\begin{array}{l}\text { SSP AM }^{* * * *} \\
(\text { CONSESP) }\end{array}$ & Sim & Sim & Não & Sim & $\begin{array}{l}\text { "Ciclo completo para o } \\
\text { TCO." }\end{array}$ & \\
\hline & $\mathrm{ABC}$ & Não & Não & Não & $\mathrm{N} / \mathrm{R}$ & $\begin{array}{l}\text { Sim. } \\
\text { Mas é necessário definir } \\
\text { melhor o que se entende } \\
\text { por ciclo completo. }\end{array}$ & \\
\hline & SINDAPEF & $\mathrm{N} / \mathrm{R}$ & Não & Não & $\begin{array}{l}\text { Sim. Poder de polícia para } \\
\text { pequenos delitos. }\end{array}$ & Sim & \\
\hline
\end{tabular}

* O Fórum Brasileiro de Segurança Pública, segundo o respondente, pela sua natureza, não pode defender propostas políticas e sim fortalecer os canais técnicos de informação capazes de influenciar os responsáveis por ações no campo da segurança pública.

** A pessoa que respondeu ao questionário assinalou que o fez representando o Observatório de Favelas, que compõe a Rede F4.

*** Posicionamento pessoal do Presidente do Conselho Nacional dos Secretários e Gestores Municipais de Segurança Pública, representante da FNP.

**** Posicionamento pessoal do Secretário de Segurança Pública do Amazonas, presidente do CONSESP.

Obs: O termo N/R (não respondeu) foi utilizado nos casos em que o respondente não assinalou nenhuma das alternativas, "sim" ou "não". 
Dos 25 respondentes, cinco disseram que defendem a proposta de unificação das polícias (FENDH, RENAESP, FNP, SSP/AM, FENAPEF), nove não responderam e 11 disseram que não a defendem (a maioria deles vinculados às instituições policiais, incluindo a unanimidade dos atores vinculados à polícia militar).

Quanto à proposta de desconstitucionalização do artigo $144^{52}$, seis atores não responderam (tendo um deles, inclusive, marcado várias interrogações no campo específico para a resposta), todos eles da sociedade civil; três responderam que defendem a proposta (Viva Rio, GGI-Ms, FENAPEF) e 14 se posicionaram contra ela (entre eles, todos os atores vinculados à polícia militar, à polícia civil e quase todos os atores vinculados à policia federal, à exceção de um deles). Do total de respondentes que se posicionaram em relação à proposta de desconstitucionalização, a grande maioria é contrária a ela.

O elevado número de atores que não respondeu, nem positivamente nem negativamente, em relação às duas propostas mencionadas acima (unificação e desconstitucionalização do art. 144), pode indicar a falta de opinião formada dos atores em torno da propositura ou a falta de explicitação do modelo proposto (por exemplo, no caso da unificação das polícias, estaria a proposta se referindo à unificação sob controle civil ou militar?).

Especialmente no caso de atores da sociedade civil, em que, também em outras respostas, alguns mencionaram textualmente a necessidade de maior debate, evidenciou-se que, de forma geral, a questão sobre as reformas das instituições policiais carece de maior discussão. Soares; Ramos, Rolim (2009) ressaltam essa falta de debates não apenas entre as organizações sociais, mas também nas universidades, nos partidos, na mídia e nas próprias instituições de segurança pública. Analisando uma pesquisa sobre o que pensam os profissionais da segurança pública, esses autores afirmam que o reconhecimento da carência de debates sobre o tema implica em reconhecer também que suas escolhas poderão ser modificadas, caso o ambiente político-cultural passe a estimular o debate, aumentando a taxa média de acesso à informação. A reflexão aplica-se também em relação ao universo de atores aqui pesquisados.

No caso da proposta de desvinculação das polícias militares do Exército, deixando as PMs de constituir reserva e força auxiliar daquela instituição, 14

\footnotetext{
${ }^{52}$ Esta proposta implica a permissão para que cada estado da federação decida sobre o modelo policial mais adequado às suas características e às particularidades de suas polícias.
} 
respondentes se posicionaram favoravelmente à proposta, seis se posicionaram contrariamente e dois não responderam (o Fórum Brasileiro de Segurança Pública e o Instituto São Paulo Contra a Violência, que remeteu toda a questão à necessidade de amplo debate para a discussão do tema). A ampla maioria dos atores sociais é favorável à proposta, com um único voto contrário da entidade representante da maçonaria (Grande Oriente do Brasil). Quando analisadas apenas as respostas dos atores vinculados às instituições policiais, a proposta, que está associada à ideia da desmilitarização das polícias militares, apesar de algumas polarizações, é defendida pelos dois atores vinculados à polícia civil e pela maioria dos atores vinculados às polícias federais. Os atores vinculados à polícia militar mostram-se divididos. Apesar dessa polarização, verifica-se, de forma geral, uma tendência favorável à desvinculação das polícias militares do Exército.

A mencionada pesquisa conduzida por Soares, Ramos, Rolim (2009, p. 25) ${ }^{53}$, aplicada a quase 65 mil profissionais da segurança pública, aponta tendência semelhante no que diz respeito a essa desvinculação (ressalvado o fato de que naquela pesquisa trabalhou-se com pessoas e nesta trabalha-se com instituições):

[...] 69,3\% dos não-oficiais da PM julgaram inadequada a vinculação de sua instituição ao Exército. Os oficiais mostraram-se mais benevolentes, como seria de se esperar. Mesmo assim, $57 \%$ concordaram com os não-oficiais. As opiniões dos Delegados e agentes da polícia civil convergiram entre si e com seus colegas da PM: 70,3\% e 55,2\%, respectivamente, identificaram-se com a avaliação negativa do vínculo entre a polícia militar e o Exército.

Quanto à proposta de ciclo completo da atividade policial, sete atores não responderam (seis da sociedade civil e o FNOP). Desses sete, três ressalvaram textualmente a necessidade de maior debate sobre o tema. Quatro atores se posicionaram contrários à proposta (os dois atores vinculados à polícia civil, 0 CNGM, e a ADPF), 13 responderam favoravelmente a ela (tendo um deles ressaltado a necessidade de se definir melhor o que se entende por ciclo completo) e um dos atores posicionou-se a favor do ciclo completo apenas para os Termos Circunstanciados de Ocorrência (TCOs). A polarização no posicionamento dos atores apresenta-se de maneira radicalizada quando analisadas só as respostas de

\footnotetext{
${ }^{53}$ A pesquisa intitulada "O que pensam os profissionais da segurança pública, no Brasil", realizada entre os meses de abril e maio de 2009, pesquisou a opinião de quase 64 mil profissionais que atuam na área de segurança, através de questionários aplicados, por meio virtual, a profissionais matriculados nos cursos de ensino à distância da RENAESP.
} 
atores vinculados à polícia militar e à polícia civil, os primeiros respondendo todos favoravelmente à instituição do ciclo completo e os segundos assumindo, de maneira unânime, posição contrária. Para além dessa polarização, também aqui, mostrou-se inequívoca a necessidade de maior debate sobre o tema.

É importante ressaltar que esse tema polarizou opiniões durante toda a etapa nacional da 1‥ CONSEG, no bojo da qual foram aplicados os questionários. Grande parte dos representantes vinculados à polícia militar defendia, na verdade, a possibilidade dessa polícia elaborar o Termo Circunstanciado de Ocorrência ${ }^{54}$, o que acabou por reduzir o debate sobre o ciclo completo da atividade policial ${ }^{55}$. Expressando a polarização das posições, ao final da Conferência restaram aprovadas duas diretrizes contraditórias, uma aprovando o ciclo completo e outra rechaçando a mesma proposta ${ }^{56}$.

Finalmente, quanto à proposta de ampliação de atribuições das guardas municipais, o alto número de atores que não responderam, nove dos 25 , indica que o tema deve ser aprofundado. Desses nove, dois afirmam expressamente não ter posicionamento sobre a proposta, um afirmou a necessidade de ampliação do debate e outro (CNCG) afirmou que é preciso cuidar para que a ampliação dos poderes de polícia da guarda não implique em invasão nas competências das polícias militares. Apenas quatro dos 25 respondentes manifestaram que não defendem a ampliação das atribuições das guardas municipais (dois deles atores vinculados à polícia militar - ANASPRA e FENEME - e dois da sociedade civil FENDH e Sou da Paz, este último dizendo estar aberto à discussão).

A grande maioria dos atores que se posicionou, 12 de 16, manifestou-se favorável à proposta de ampliação de atribuições das guardas, entre eles os três atores que se vinculam ao âmbito municipal. Dos que se manifestaram favoravelmente à proposta, três expressaram que as guardas municipais devem ter atuação preventiva e comunitária; um dos atores disse que a guarda deve fazer trabalhos comunitários; dois afirmaram que a guarda deve ter seu poder de polícia

\footnotetext{
${ }^{54}$ Sobre os TCOs, o tema foi brevemente abordado no capítulo 2, seção 2.3, Nota de Rodapé № 16 .

${ }^{55}$ Recuperando a discussão realizada no capítulo 2 , entende-se por ciclo completo da atividade policial a atuação por uma mesma polícia tanto no policiamento ostensivo, de manutenção da ordem pública, quanto na investigação para apuração da autoria e das circunstâncias em que ocorreu um determinado delito. Em nossa opinião, portanto, o fato de uma polícia assumir apenas um aspecto pontual de uma dessas fases não caracteriza o ciclo completo.

${ }^{56}$ Esse tema será retomado no capítulo 5 , na seção 5.3.6, quando da análise dos resultados da Conferência.
} 
ampliado para a atuação em pequenos delitos (um deles disse expressamente que a guarda deve, para tanto, assumir atribuições das PMs, no que diz respeito a delitos de pequeno potencial ofensivo, contravenções penais e ilícitos administrativos; outro se referiu à ampliação das atribuições das guardas para que estas possam formalizar ocorrências por meio de procedimentos administrativos ágeis ou Termos Circunstanciados, encaminhando o procedimento diretamente para o Ministério Público). Portanto, entre os atores favoráveis também há uma divisão entre os que defendem a ampliação do papel das guardas para prevenção, os que defendem que estas se tornem polícias preventivas e os que defendem a tese de que, em casos específicos, atribuições típicas das polícias estaduais sejam estendidas às guardas (ADPF, FENAPEF e SINDAPEF).

A última pergunta formulada pretendia verificar, de modo geral, o posicionamento dos atores com relação ao modelo de segurança pública atualmente existente. Ela foi assim redigida: "Para sua instituição, o atual modelo de segurança pública: a) não precisa ser alterado; b) não precisa ser alterado, mas é preciso investir mais em recursos materiais e humanos; c) não precisa ser alterado, mas é preciso modernizar a gestão; d) precisa ser alterado para incluir novos atores, como os municípios, fortalecendo-se a prevenção, com maior participação social na implementação e no controle das políticas públicas de segurança; e) precisa ser estruturalmente reformulado, inclusive com a criação de um novo modelo de instituições policiais". O respondente ficava livre para assinalar uma ou mais opções. As respostas foram sintetizadas no quadro abaixo: 
Sobre o atual modelo de segurança pública

\begin{tabular}{|c|c|c|c|c|c|c|}
\hline & ATORES & $\begin{array}{c}\text { Não } \\
\text { precisa } \\
\text { ser } \\
\text { alterado }\end{array}$ & $\begin{array}{c}\text { Não precisa } \\
\text { ser alterado, } \\
\text { mas precisa } \\
\text { de mais } \\
\text { investimentos } \\
\text { materiais e } \\
\text { humanos }\end{array}$ & $\begin{array}{c}\text { Não precisa } \\
\text { ser alterado, } \\
\text { mas é } \\
\text { preciso } \\
\text { modernizar } \\
\text { a gestão }\end{array}$ & $\begin{array}{c}\text { Precisa ser } \\
\text { alterado para } \\
\text { incluir novos } \\
\text { atores, como } \\
\text { os municípios, } \\
\text { com mais } \\
\text { prevenção, } \\
\text { participação e } \\
\text { controle }\end{array}$ & $\begin{array}{c}\text { Precisa ser } \\
\text { estrutural/e } \\
\text { reformulado, } \\
\text { criando-se } \\
\text { novo modelo } \\
\text { para as } \\
\text { instituições } \\
\text { policiais }\end{array}$ \\
\hline \multirow{9}{*}{ 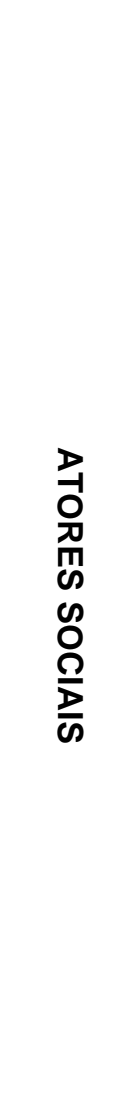 } & FENDH & & & & & $x$ \\
\hline & ISPCV & & & & $x$ & \\
\hline & FBSP & & & & & $x$ \\
\hline & $\begin{array}{c}\text { Instituto } \\
\text { Sou da Paz }\end{array}$ & & & & $x$ & \\
\hline & Viva Rio & & & & $x$ & \\
\hline & $\begin{array}{c}\text { Desarma } \\
\text { Brasil }\end{array}$ & & & & $x$ & \\
\hline & Rede F4 & & & & $X$ & $x$ \\
\hline & $\begin{array}{c}\text { Grande } \\
\text { Oriente do } \\
\text { Brasil }\end{array}$ & & $X$ & $\mathrm{X}$ & $x$ & \\
\hline & RENAESP & & & & $X$ & $X$ \\
\hline \multirow{3}{*}{ 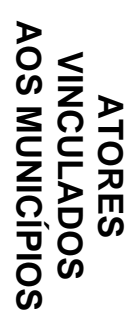 } & FNP & & & & $x$ & \\
\hline & GGI-Ms & & & & $x$ & $x$ \\
\hline & CNGM & & & & $x$ & \\
\hline
\end{tabular}




\begin{tabular}{|c|c|c|c|c|c|c|}
\hline & ATORES & $\begin{array}{c}\text { Não } \\
\text { precisa } \\
\text { ser } \\
\text { alterado }\end{array}$ & $\begin{array}{c}\text { Não precisa } \\
\text { ser alterado, } \\
\text { mas precisa } \\
\text { de mais } \\
\text { investimentos } \\
\text { materiais e } \\
\text { humanos }\end{array}$ & $\begin{array}{c}\text { Não precisa } \\
\text { ser alterado, } \\
\text { mas é } \\
\text { preciso } \\
\text { modernizar } \\
\text { a gestão }\end{array}$ & $\begin{array}{c}\text { Precisa ser } \\
\text { alterado para } \\
\text { incluir novos } \\
\text { atores, como } \\
\text { os municípios, } \\
\text { com mais } \\
\text { prevenção, } \\
\text { participação e } \\
\text { controle }\end{array}$ & $\begin{array}{c}\text { Precisa ser } \\
\text { estrutural/e } \\
\text { reformulado, } \\
\text { criando-se } \\
\text { novo modelo } \\
\text { para as } \\
\text { instituições } \\
\text { policiais }\end{array}$ \\
\hline \multirow{4}{*}{ 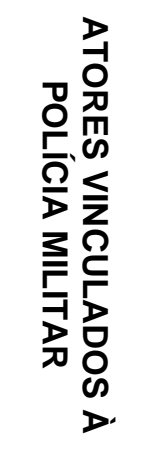 } & CNCG & & & $\mathrm{X}$ & & \\
\hline & AMEBRASIL & & $x$ & $x$ & & \\
\hline & ANASPRA & & & $X$ & & \\
\hline & FENEME & & & $X$ & & \\
\hline \multirow{2}{*}{ 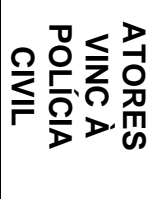 } & ADEPOL & & & & $x$ & \\
\hline & COBRAPOL & & & & $x$ & \\
\hline \multirow{3}{*}{ 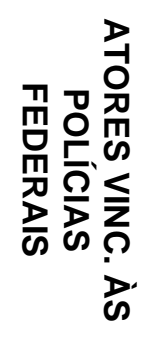 } & FENAPRF & & & & $x$ & \\
\hline & ADPF & & & & $x$ & \\
\hline & FENAPEF & & & & & $x$ \\
\hline \multirow{4}{*}{$\begin{array}{l}\text { 옴 } \\
\text { 공 } \\
\text { O }\end{array}$} & FNOP & & & & & $X$ \\
\hline & $\begin{array}{c}\text { SSP - } \\
\text { Amazonas } \\
\text { (CONSESP) }\end{array}$ & & & & $x$ & \\
\hline & $A B C$ & & & & $x$ & \\
\hline & SINDAPEF & & & & & $x$ \\
\hline
\end{tabular}


Dos nove atores sociais, sete entendem que é preciso alterar o atual modelo para a inclusão do município como novo ator, com maior participação social na implementação e no controle das políticas públicas de segurança. Desses sete, dois (Rede F4/Observatório de Favelas e RENAESP) apontam também a necessidade de reformas estruturais, inclusive a criação de um novo modelo policial. Os outros dois atores, FENDH e FBSP, têm o mesmo posicionamento desses últimos, afirmando a necessidade de reformas estruturais. Polarizando com estes, um único ator da sociedade civil (Grande Oriente do Brasil), para além de entender que são necessárias alterações para a inclusão de novos atores e maior participação social, não manifestou serem necessárias alterações estruturais no modelo das instituições policiais, bastando maiores investimentos em recursos humanos e materiais e a modernização da gestão.

Os três atores representantes do âmbito municipal entendem que o modelo deve ser alterado para a inclusão de novos atores, como os municípios, e maior participação social. Um deles (GGI-Ms) entende que, além disso, é necessário também reformular estruturalmente o atual sistema, inclusive para se criar um novo modelo policial.

Todos os atores vinculados à polícia militar se posicionam no sentido de que não é preciso alterar o atual modelo de segurança pública, sendo necessário apenas modernizar a gestão. Um desses quatro atores entende ainda que, além de modernizar a gestão, é necessário investir mais em recursos humanos e materiais. Os atores vinculados à polícia civil apontam a necessidade de alterar o modelo para a inclusão de novos atores, como os municípios, e para maior participação social. Com o mesmo posicionamento estão os atores vinculados às polícias federais, com exceção da FENAPEF, que entende serem necessárias reformas estruturais no atual modelo das instituições policiais.

Também entendem ser necessário reformular estruturalmente o sistema, inclusive para criação de um novo modelo de polícia, a Frente Nacional de Ouvidores de Polícia (FNOP) e o SINDAPEF. A ABC e o secretário de segurança pública do Amazonas (CONSESP) entendem que é necessário reformular o atual modelo para a inclusão de novos atores e maior participação social.

Verifica-se, portanto, que não há consenso sobre a necessidade ou não de se reformular estruturalmente $o$ atual modelo. Todos os atores vinculados às polícias, à 
exceção de um, acreditam que não são necessárias reformas estruturais nas instituições policiais. De forma geral, oito dos 25 atores defendem a reforma estrutural do sistema, inclusive a criação de um novo modelo policial, e cinco atores defendem que não há necessidade de alterar o atual modelo, sendo necessário apenas modernizar a gestão e/ou aumentar os investimentos. Dezesseis atores defendem (unicamente ou de maneira combinada com alguma outra opção) a alteração do sistema para inclusão de novos atores, como os municípios, e maior participação social.

Uma das perguntas feitas na pesquisa de Soares, Ramos, Rolim (2009) aos profissionais de segurança pública referia-se especificamente a reformas no modelo policial brasileiro, tendo sido formulada da seguinte maneira:

\begin{abstract}
Na maioria dos países, as competências das polícias são definidas segundo dois critérios básicos: ou as polícias atuam em áreas geográficas próprias ('cada uma em seu quadrado') ou as polícias atuam de forma especializada, frente à natureza dos tipos penais (cada polícia é responsável por certos tipos de crime). Desta forma, as polícias possuem o que se convencionou chamar de 'ciclo completo de policiamento'. No Brasil, temos outro modelo onde as polícias estaduais atuam na mesma área geográfica e tratam dos mesmos crimes, havendo uma divisão de competência que confere a cada uma delas metade do ciclo policial. Cabe às polícias militares as funções ostensivas de patrulhamento e prevenção e, às polícias civis, as funções judiciais de investigação. Em sua opinião, o que seria o modelo mais adequado para a realidade brasileira atual?
\end{abstract}

As respostas poderiam ser: 1. Polícias Militares/Civis unificadas estaduais civis; 2. Polícias Militares/Civis unificadas estaduais militares; 3. Implantação de polícias atuando em circunscrição geográfica; 4. Implantação de polícias atuando conforme tipos de crimes; 5 . Manutenção do atual modelo de polícia; 6 . Não tenho opinião formada sobre o assunto.

Reproduzimos aqui os resultados obtidos, a fim de ampliarmos a visão da comunidade da política e do posicionamento de diferentes grupos de profissionais da segurança pública, ainda que, nesse caso, não se possa considerar cada um dos quase 65 mil respondentes como atores institucionais. A utilidade de se avocar, aqui, a pesquisa de Soares, é a de se perceber que os atores não são compostos como blocos monolíticos de preferências, que há embates, polarizações, fragmentações. O quadro abaixo favorece essa percepção, ainda que as escolhas induzidas não tenham sido as mesmas em relação àquelas formuladas no questionário aplicado aos atores. 
Opinião dos profissionais sobre modelos de polícia, segundo corporação e patente

\begin{tabular}{|c|c|c|c|c|c|c|c|c|}
\hline & $\begin{array}{c}\text { Praças } \\
\text { PM }\end{array}$ & $\begin{array}{c}\text { Oficiais } \\
\text { PM }\end{array}$ & $\begin{array}{c}\text { Agentes } \\
\text { PC }\end{array}$ & $\begin{array}{c}\text { Delegad. } \\
\text { PC }\end{array}$ & Bomb. & $\begin{array}{c}\text { Guardas } \\
\text { Munic. }\end{array}$ & $\begin{array}{c}\text { Sist. } \\
\text { Penit. }\end{array}$ & Total \\
\hline $\begin{array}{c}\text { Polícias } \\
\text { unificadas } \\
\text { estaduais } \\
\text { civis }\end{array}$ & $42,1 \%$ & $15,8 \%$ & $28,1 \%$ & $43,7 \%$ & $25,3 \%$ & $27,3 \%$ & $24,5 \%$ & $34,4 \%$ \\
\hline $\begin{array}{c}\text { Polícias } \\
\text { unificadas } \\
\text { estaduais } \\
\text { militares }\end{array}$ & $18,8 \%$ & $27,1 \%$ & $3,0 \%$ & $1,7 \%$ & $19,1 \%$ & $11,2 \%$ & $12,0 \%$ & $15,4 \%$ \\
\hline $\begin{array}{c}\text { Atuação - } \\
\text { circusnc. } \\
\text { geográfica }\end{array}$ & $6,3 \%$ & $15,2 \%$ & $6,7 \%$ & $4,9 \%$ & $6,2 \%$ & $13,0 \%$ & $8,7 \%$ & $7,7 \%$ \\
\hline $\begin{array}{c}\text { Atuação- } \\
\text { tipos de } \\
\text { crime }\end{array}$ & $9,8 \%$ & $18,7 \%$ & $13,4 \%$ & $6,1 \%$ & $13,0 \%$ & $15,7 \%$ & $18,1 \%$ & $12,2 \%$ \\
\hline $\begin{array}{c}\text { Manut. do } \\
\text { modelo } \\
\text { atual }\end{array}$ & $14,6 \%$ & $18,6 \%$ & $41,0 \%$ & $40,1 \%$ & $18,0 \%$ & $18,8 \%$ & $22,2 \%$ & $20,2 \%$ \\
\hline $\begin{array}{c}\text { Não tenho } \\
\text { opinião } \\
\text { formada }\end{array}$ & $8,4 \%$ & $4,7 \%$ & $7,7 \%$ & $3,5 \%$ & $18,5 \%$ & $13,9 \%$ & $14,6 \%$ & $10,0 \%$ \\
\hline
\end{tabular}

Fonte: (SOARES; RAMOS; ROLIM; 2009).

À luz do exposto até aqui e, em especial da análise das respostas dadas ao questionário, é possível identificar três grandes posicionamentos entre os atores da comunidade da política de segurança pública: 1) posição pela manutenção do atual modelo, com modernização da gestão e maior investimento em recursos materiais e humanos; 2) posição que defende a inclusão de novos atores na segurança pública, como os municípios, e maior participação comunitária na implementação e no controle das políticas de segurança; 3) posição que defende reformas estruturais, com a criação de um novo modelo para as instituições policiais.

As mencionadas posições comportam variações, combinações e ambiguidades e não podem ser relacionadas a um único ator de forma homogênea. Não apenas a cada posição vinculam-se diferentes atores, mas um mesmo ator pode reunir grupos com diferentes posições. Assim, por exemplo, não é possível 
afirmar que a polícia militar é composta apenas por atores que defendem a manutenção do atual modelo, como se verifica nas respostas obtidas na pesquisa de Soares (2009). No mesmo sentido, defender a prevenção, por exemplo, não significa considerar a modernização da gestão das instituições policiais menos importante, nem implica afirmar que adeptos desse modelo não possam postular também reformas estruturais, como ficou bastante claro nas respostas obtidas pelo questionário aplicado aos atores.

A análise dos especialistas também reflete essas combinações. Para Mesquita e Ricardo (2003), é possível obter avanços com a prevenção e com o controle da violência dentro do quadro institucional existente, adotando-se medidas como o policiamento comunitário, as ouvidorias de polícia e as penas alternativas. Já para o primeiro Ouvidor das Polícias do Estado de São Paulo, Benedito Mariano, as resistências a mudanças estruturais nas polícias e a falta de uma política nacional de segurança pública também alimentam a violência, porém, apesar de defender que sem reformas estruturais não se consegue acabar com problemas endêmicos nas instituições policiais (1999), o especialista defende também uma série de medidas incrementais, especialmente referidas a reformas no quadro normativo das instituições (regulamentos disciplinares, leis orgânicas) e ao fortalecimento dos mecanismos de controle interno e externo, que melhorariam a atuação policial (2006).

Pode-se afirmar que as propostas de mudança no modelo da política de segurança pública estruturam-se em dois sentidos. O primeiro diz respeito a um alargamento da concepção mesma da política de segurança pública, que leva em conta não só o crime e o criminoso, mas os múltiplos fatores causais da violência, enfatizando o papel das políticas preventivas, para cujo desenvolvimento são necessários cooperação, integração, participação comunitária e a inclusão de novos atores para além das instituições que historicamente são responsáveis pelo controle da lei e da ordem. O segundo refere-se a mudanças nas instituições policiais propriamente ditas, incluindo propostas de mudanças incrementais e/ou reformistas radicais. As diferentes propostas de mudanças constroem-se em torno desses dois sentidos, algumas vezes dissociando-os e outras vezes integrando-os. 
Especificamente no que concerne à posição que defende reformas estruturais no arranjo institucional vigente de segurança pública, como se depreende dos resultados das pesquisas apresentadas na seção anterior, parece não haver ainda consenso sobre o novo desenho a ser implementado. A literatura temática disponível, bem como a análise de fontes documentais, mostra que, especialmente a partir da década de 1990, várias propostas de reformas estruturais no sistema de segurança pública brasileiro têm sido apresentadas por diferentes atores, de diferentes matizes ideológicos, cujas preferências vão desde a unificação das polícias até a desconstitucionalização do artigo 144 da Constituição Federal, passando pela ampliação dos poderes das guardas municipais. Nenhuma das proposituras legislativas ${ }^{57}$ que visavam a reformas estruturais do modelo da política de segurança pública obteve êxito.

Algumas propostas, como a de unificar as polícias $^{58}$, são mais antigas do que usualmente se imagina. Ainda em pleno período autoritário militar, quando do processo de elaboração da Constituição de 1967, abriu-se o prazo de cinco dias para que especialistas oferecessem eventuais emendas ao projeto de Constituição. Alguns juristas, reunidos a convite do professor Hely Lopes Meirelles, levantaram a proposta de unificação das polícias. Segundo Dallari (1991), "o próprio Comandante da polícia militar foi à casa do Prof. Hely Lopes Meirelles para dizer que aquela polícia não aceitava a unificação". Para Dallari, o crescimento e a natureza militarizada da polícia militar passou a exercer um grande poder de pressão e de resistência, o que explicaria "o porquê de não se ter avançado no sentido da unificação, tantas vezes proposta e reconhecida como conveniente" (DALLARI, 1991, p. 65). Nos anos seguintes, a proposta de unificação foi, por diversas vezes,

\footnotetext{
${ }^{57}$ Em 2002, havia 245 proposições legislativas versando sobre o tema da segurança pública em tramitação no Congresso Nacional, o que ensejou a instituição, em março daquele ano, de uma Comissão Especial Mista, composta por 19 deputados federais e por 19 senadores, que tinham por missão levantar as causas e os efeitos da violência e analisar, em conjunto, todas as proposições em andamento nas duas Casas.

${ }^{58}$ Sobre o tema da unificação das polícias no Brasil, ver Medeiros (2004).
} 
reformulada, entre outras, em 1997, pelo então Governador de São Paulo, Mario Covas, e, em dezembro de 1999, pelo Fórum Nacional de Ouvidores de Polícia ${ }^{59}$.

Para Sette Câmara (1999), ex-presidente do Fórum Brasileiro de Segurança Pública, a proposta de unificação "agrada a qualquer grupo policial, desde que seja ele quem mande". Contrário à proposta de desmilitarização da polícia militar e também à proposta de unificação ${ }^{60}$, Sette Câmara defende a integração das duas polícias como forma de se aumentar a qualidade do serviço prestado e de reduzir os seus custos.

Pesquisa feita por Arantes e Cunha (2003), objetivando conhecer como os delegados de polícia se posicionam diante de várias propostas de reformas na política de segurança pública, apontou que pouco mais de $35 \%$ dos entrevistados concordavam "totalmente" com a proposta de unificação das polícias civil e militar, cerca de $40 \%$ concordava "em termos", $20 \%$ discordava totalmente e o restante discordava "em termos". A pesquisa de Arantes e Cunha (2003) mostrou ainda que as discordâncias com a proposta de unificação entre os delegados de polícia são maiores nos estados do Nordeste e do Centro-Oeste, o que expressa a necessidade de um consenso federativo, não bastando, por exemplo, que o consenso se estabeleça apenas em São Paulo (MEDEIROS, 2004).

Vários autores chamam a atenção para a inadequação de uma polícia com estrutura militar ser responsável por policiamento de natureza civil (BICUDO, 2000; CARVALHO, 2003; DALLARI, 1991) e para os problemas decorrentes do arranjo dual das instituições policiais de ciclo incompleto (MARIANO, 2004; MUNIZ; ZACCHI, 2005; ZAVERUCHA, 2004). Apesar de não haver consenso entre os atores da comunidade da política sobre o desenho de um novo modelo, começa a surgir um movimento em relação à desmilitarização da polícia militar. Como se depreende dos resultados da pesquisa analisada na seção anterior, a proposta de desvinculação da polícia militar do Exército é majoritária entre os atores sociais pesquisados ${ }^{61}$ e entre os atores vinculados à polícia civil, dividindo preferências entre os atores vinculados

\footnotetext{
${ }^{59}$ Além desses atores, propunham também a unificação das polícias a PEC $46 / 91$, de autoria do deputado Hélio Bicudo, e a PEC 613/98, de autoria da deputada Zulaiê Cobra, entre outras.

${ }^{60}$ Para Sette Câmara (1999), a desmilitarização das polícias militares apenas aumentaria o poder das Forças Armadas, fortalecendo a União em detrimento dos estados. Além disso, para realizar a sua atribuição constitucional de restauração e manutenção da ordem pública é necessário, segundo esse autor, uma força púbica armada militarmente. Quanto à unificação, Sette Câmara entende que os obstáculos administrativos inviabilizam as propostas.

${ }^{61}$ É importante ressaltar que a proposta de desmilitarização das polícias militares está na agenda das entidades de direitos humanos desde o início da transição democrática.
} 
à polícia militar. No entanto, a efetiva aprovação pelo Congresso Nacional de proposta nesse sentido dependerá, entre outros fatores, da coalizão que os atores favoráveis conseguirem construir e de como se dará sua interação com outras instituições políticas.

A aprovação de propostas de reformas estruturais nas instituições policiais exige a construção de um amplo consenso federativo, como já foi mencionado, em razão tanto da responsabilidade dos estados sobre as polícias como da relativa autonomia das instituições policiais, que podem exercer influência sobre o processo decisório (ARANTES; CUNHA, 2003).

A questão das diferenças e especificidades regionais em um país com dimensões continentais como o Brasil, é um dos principais argumentos dos que defendem a proposta de desconstitucionalização do artigo 144 da Constituição Federal, de forma a permitir que cada estado da federação decida sobre o arranjo institucional de suas polícias. Na esteira da desconstitucionalização do artigo 144, que estabelece quais órgãos são responsáveis pela segurança pública e suas respectivas competências, pode-se citar a PEC 514/97, formulada pelo Governo de Fernando Henrique Cardoso, propondo que cada estado da federação estabelecesse os órgãos de segurança pública a serem criados. Proposta parecida foi formulada no Programa de Governo do então candidato à presidência Luiz Inácio Lula da Silva. Porém, entre elas, verificam-se diferenças como, por exemplo, no fato de que, na proposta de FHC, caso um estado decidisse pela manutenção da polícia militar, esta manteria sua natureza de força auxiliar do Exército, enquanto que, na proposta do Programa de Governo de Lula, em qualquer caso, a polícia estadual ficaria sob controle civil.

Mais recentemente, a PEC 21/2005, de autoria do senador Tasso Jereissati, também propôs a desconstitucionalização do artigo 144 da Constituição Federal, a fim de que cada estado pudesse organizar livremente sua polícia, unificando-a, mantendo duas ou mais instituições, desde que cada uma delas realizasse o ciclo completo da atividade policial. Segundo Lemle (2007), em março de 2007, o próprio senador Jereissati retirou a PEC da pauta de votação da Comissão de Constituição e Justiça, por considerá-la "polêmica demais". Consta da matéria dessa articulista que 
[...] oficiais ligados à Associação dos Oficiais Militares Estaduais do Brasil (AMEBRASIL), à Federação Nacional de Entidades de Oficiais Militares Estaduais (FENEME) e ao Conselho dos Comandantes Gerais das Polícias Militares e Corpos de Bombeiros Militares (CNCG) manifestaram-se contra a desconstitucionalização das polícias.

Decorridos pouco mais de dois anos, esses atores manifestaram o mesmo posicionamento na pesquisa elaborada no bojo desta dissertação.

Tema também controverso é o que diz respeito ao papel das guardas municipais. Assim como ocorreu entre os atores respondentes do questionário, os especialistas também se dividem. Para Silva Filho (2000), a criação de guardas municipais armadas é equivocada por possibilitar uma usurpação das atribuições das forças policiais estaduais. Segundo o autor, os recursos municipais gastos com as guardas deveriam ser gastos com outros projetos sociais, uma vez que as guardas municipais só seriam úteis se subordinadas às polícias militares. Mariano (2004) entende que as guardas já exercem atribuições de polícia de fato, embora não de direito, no entanto, defende que as guardas sejam regulamentadas como polícias municipais estritamente preventivas e comunitárias, realizando, dessa forma, atribuições que não colidem com as competências das policias estaduais ${ }^{62}$.

Segundo se depreende de estudo da Consultoria Legislativa da Câmara dos Deputados, havia, em 2005, mais de 20 projetos de emenda constitucional versando sobre guardas municipais e seu emprego em atividades de segurança pública, em tramitação na Câmara dos Deputados. Segundo o estudo,

desde 1992 são encontradas PECs tratando sobre organização, atribuições, funcionamento e atuação das guardas municipais, sob as mais diversas óticas $^{63}$, criando as polícias municipais, concedendo às guardas municipais

${ }^{62}$ Quando Benedito Mariano presidia o Conselho Nacional das Guardas Municipais, o órgão apresentou ao então Ministro da Justiça proposta de regulamentação nacional das guardas para que estas desempenhassem atribuições de policiamento preventivo e comunitário e fossem dotadas de órgão corregedor e ouvidoria, autônoma e independente de seus comandos. A proposta foi recentemente adotada pelos 12 municípios que integram a Câmara Setorial de Segurança Urbana da Região Oeste da Grande São Paulo e pelo Núcleo Estratégico de Segurança Urbana do Consórcio Municipal do Grande ABC, integrado por sete municípios da região metropolitana de São Paulo.

${ }_{63}$ Exemplificando a amplitude das proposições, pode-se citar a PEC449/2001, que propõe a revogação do dispositivo constitucional que autoriza a criação de guardas municipais, transferindo os atuais efetivos para as polícias civil e militar; a PEC291/2000, que propõe ampliar a atribuição das guardas a fim de que estas passem a executar ações de segurança pública de maneira complementar às policiais estaduais; a PEC 276/2000, que propõe descentralizar o sistema de segurança pública, transferindo para os municípios com mais de 1 milhão de habitantes a competência para definir e executar a política de segurança pública, organização do sistema penitenciário e criação das guardas municipais; a PEC 250/2000, que propõe a permissão às guardas municipais para a execução de funções de polícia judiciária e de polícia ostensiva, de maneira 
a condição de órgãos da segurança pública e ampliando sua competência e outras ideias correlatas. (ROCHA, 2005, p. 3)

Descreveu-se, até aqui, a existência de uma comunidade política ampliada, com a emergência de novos atores políticos e sociais, e ainda bastante cindida no que diz respeito às suas posições e preferências reformistas. A seção seguinte procurará compreender os motivos pelos quais nenhuma das inúmeras propostas de reforma estrutural no arranjo institucional da segurança pública conseguiu prosperar até o momento.

4.5 Resistência do atual modelo de segurança pública, face às propostas de reformas estruturais

O fato de a segurança pública ser hoje um dos problemas mais citados pelos brasileiros em pesquisas de opinião, a explicitação, nas décadas de 1980-1990, da crise da segurança pública e a existência de atores reformistas e de inúmeros projetos de emenda constitucional versando sobre reformas estruturais não foram elementos suficientes para que se levasse a cabo qualquer mudança capaz de promover uma ruptura institucional no modelo de segurança pública brasileiro. Embora, nas palavras de Arantes e Cunha (2003, p. 96), já se tenham acumulado várias evidências sobre a crise da segurança pública, "ainda estamos longe de um processo articulado e consequente de reforma institucional nessa área". O que explicaria tamanha resistência da política de segurança pública à mudança?

Para alguns autores do neoinstitucionalismo histórico, as dificuldades para se emendar a constituição e o poder de veto das assembleias legislativas estaduais, típicas do federalismo, atuariam como um sistema de freio às políticas nacionais, conferindo estabilidade ao pacto federativo, que de outra forma se tornaria instável (OBONGER et al., 2005). Poder-se-ia argumentar, à luz desse postulado, que as reformas estruturais nas instituições policiais não foram feitas em razão de dificuldades dessa natureza?

concorrente com as polícias civil e militar; a PEC 87/1999, que propõe a substituição das guardas municipais por polícias municipais no Distrito Federal, nas capitais dos estados e em municípios com mais de 1 milhão de habitantes. 
Certamente a aprovação de um projeto de emenda constitucional exige muita negociação e uma imprescindível formação de coalizões também no Estado Federativo brasileiro. Não obstante, no país, as regras para a aprovação de emendas constitucionais são menos exigentes que em outros países que preveem oportunidades de veto aos governos territoriais, como é o caso, por exemplo, dos EUA. No caso brasileiro, vários estudos demonstram uma capacidade limitada de veto dos governos estaduais às iniciativas da União. Para Arretche (2007), a referida limitação decorre da combinação da centralização da autoridade normativa com a ausência de arenas decisórias adicionais. Também por conta dessa relativa facilidade das regras do processo decisório brasileiro, a Constituição Federal de 1988 é a mais emendada de nossa história, contando 57 emendas até o final do ano de 2008, nenhuma delas alterando a estrutura da política de segurança pública.

Importa menos, do ponto de vista dos resultados, se o Brasil é ou não um estado federativo. Importa analisar como está distribuída a autoridade, isto é, se a competência para determinada política é centralizada ou não, se a União tem capacidade de induzir as decisões das unidades subnacionais, qual o efeito de cada instituição e, sobretudo, quais os efeitos de combinação das várias instituições. Não se pode derivar do federalismo em si, afirma Arretche (2007), os resultados do processo decisório, que só podem ser compreendidos na sua interação com outras instituições políticas.

Segundo Melo (2005, p. 85), os reformadores "operam dentro de um conjunto institucionalmente constrangido por regras que definem as capacidades e incentivos que têm para realizar a reforma". Às regras de direito - definidas como aquelas que compõem o desenho constitucional estabelecendo procedimentos que facilitam ou dificultam a expressão do poder político em regras concretas - deve-se associar as regras de fato, isto é, aquelas que alteram a maneira pela qual as instituições formais operam na prática (IMMERGUT, 1996). Essa combinação institucional determina lógicas distintas de tomada de decisão que definem os parâmetros, tanto da ação do governo quanto da influência dos grupos de interesse.

No caso da política de segurança pública, os desafios para reformar seu modelo se iniciam pela multiplicidade de atores, com diferentes interesses na área da segurança pública. Há, no Brasil, hoje, aproximadamente, 450 mil policiais militares (incluídos os corpos de bombeiros) e 150 mil policiais civis. O efetivo das 
polícias estaduais representa cerca de três vezes o tamanho do efetivo do Exército (com 190 mil militares na ativa) e é mais de 50 vezes maior que o efetivo da polícia federal (com efetivo de $11 \mathrm{mil}$ policiais em todo o Brasil). Interessa ao Exército perder o controle sobre as polícias militares ou aos governos estaduais se responsabilizarem pela escolha do modelo que desejam para suas polícias? Interessa às corporações a unificação das polícias? O tema das reformas no modelo de segurança pública e, especificamente, das instituições policiais, como demonstrado pelas respostas dadas ao questionário, necessita ainda de muito debate público. A existência de múltiplas posições dos atores que integram a comunidade da política, como visto na sessão 4.3, expressa, por um lado, a incorporação de novas visões sobre a segurança pública que coexistem com visões mais antigas. Por outro lado, essa diversidade de posições impõe desafios à construção de uma coalizão reformadora majoritária capaz de dar sustentação a uma eventual reforma.

As características históricas das instituições policiais brasileiras, bem como as históricas rivalidades entre as polícias estaduais não geram apenas resistências ao trabalho integrado, como visto no capítulo 2, mas dificultam o processo de reformas $^{64}$. As decisões passadas em relação aos arranjos institucionais impõem aos governos constrangimentos a decisões futuras, limitando sua capacidade de ar políticas novas. Embora as escolhas passadas não impossibilitem a reforma estrutural do modelo vigente, limitam as possibilidades de mudança, na medida em que a escolha por reformas radicais do modelo da política impõe altos custos de reversão. Esse mecanismo, denominado pela literatura neoinstitucionalista histórica de path dependence ou, simplesmente, de padrão de dependência da trajetória, torna ainda maiores os desafios a serem enfrentados pelos atores reformadores.

Quando a mudança radical no modelo de uma política impõe altos custos de reversão (path dependence), a tendência é que prevaleçam as preferências por mudanças incrementais, isto é, mudanças no interior de um mesmo modelo de

\footnotetext{
${ }^{64}$ Discutindo a necessidade de reformas profundas nas instituições do sistema de justiça criminal, Adorno (1999) aponta tanto para a questão dos fortes lobbies, que dificultam mudanças radicais na política, como para o fator da tradição, isto é, do forte legado histórico de políticas repressivas autoritárias de controle da lei e da ordem.
} 
política $^{65}$. Pierson (2004) explica que os custos de reversão de uma política podem ser elevados em relação a diferentes aspectos: a) Custos elevados de instalação de uma nova instituição formal; b) Efeitos de aprendizagem (perda de investimentos já feitos para difundir ou ensinar determinadas regras ou procedimentos, caso se escolha um novo modelo); c) Efeitos de coordenação (são os efeitos decorrentes da adesão de atores e interesses organizados em torno de uma política ou instituição formal, tornando mais difíceis as mudanças radicais); d) Expectativas adaptativas (processos associados à decisão dos atores, isto é, uma determinada alternativa sobrevive não por ser necessariamente a melhor, mas porque os atores envolvidos fazem uma aposta de que é ela que vai sobreviver).

Mudar o modelo da política de segurança pública brasileira implica alto custo de reversão, no mínimo, pelos efeitos de aprendizagem envolvidos e pelos efeitos de coordenação relativos à aderência de atores e interesses organizados em torno do modelo que se quer mudar.

Nesse sentido, Sette Câmara (1999, p. 25) chama atenção para os obstáculos administrativos impostos, por exemplo, à proposta de unificação das polícias estaduais. Esses obstáculos, segundo o especialista, seriam de tamanha monta que a proposta se torna praticamente inviável. Ele alude ainda ao aspecto da tradição:

São quase dois séculos de história, milhões de pessoas, policiais civis e militares, da ativa e da reserva, ou aposentados, às vezes famílias inteiras com fortes laços com as instituições, que não gostariam de vê-las simplesmente desaparecer. A tradição remete também para a questão da credibilidade. Esta se ancora sempre em raízes históricas.

Muniz e Zacchi (2005) ressaltam o forte componente histórico-cultural das policiais civis e militares, relativo ao enraizamento de culturas organizacionais muito distintas e a constituição de histórias institucionais, métodos de trabalho e rotinas mutuamente desconhecidas. No mesmo sentido, Battibugli (2006) aponta as rivalidades entre as instituições policiais e uma cultura policial corporativista entre os problemas que, de maneira persistente, marcam o sistema de segurança pública brasileiro ao longo de sua história e que contribuem para protelar reformas estruturais.

${ }^{65}$ Diferentemente das chamadas reformas radicais ou estruturais, denominam-se mudanças ou reformas "incrementais" aquelas que, mesmo sendo relevantes, não são suficientes para conformar um novo modelo de política. 
Se compararmos o processo de reformas da política de saúde com o processo de reforma da política de segurança pública, fica claro que falta à segunda pelo menos um requisito essencial, qual seja, o estabelecimento de uma coalizão mínima, porém ampla, capaz de dar sustentação a uma mudança do modelo da política. Na política de saúde - para além de um desenho virtuoso do Sistema Único de Saúde, com centralização normativa no governo federal e com a instituição de vários mecanismos de coordenação indutores da adoção da política pelas unidades subnacionais - durante décadas, construiu-se uma coalizão poderosa entre os mais diferentes atores daquela comunidade (sanitaristas, hospitais privados, médicos, indústria farmacêutica) ${ }^{66}$. Nesse sentido, a agenda de reformas da segurança pública é ainda bastante recente. A comunidade da política se ampliou, mas as negociações, as agendas mínimas em torno de reformas estruturais não foram ainda estabelecidas $^{67}$.

Mesmo que se chegue a um consenso sobre quais são as reformas estruturais necessárias, será ainda preciso construir uma ampla coalizão reformista em torno desse novo modelo. Por sua vez, essa construção tende a produzir reformas menos radicais porque requer que se lance mão de estratégias de incorporação de grupos com diferentes preferências, o que vai redefinindo o desenho da política (MENICUCCI, 2007). Nesse sentido, para o neoinstitucionalismo histórico, as regras do jogo, os contextos institucionais não moldam preferências, moldam estratégias.

No caso do modelo histórico da política de segurança pública, o padrão fortemente dependente da trajetória explica, em parte, a resistência a mudanças. Outros fatores ajudam a explicá-la, como a inexistência de uma coalizão reformadora ampla, uma comunidade de atores com diferentes visões, com interesses corporativos e, por vezes, polarizados, o exíguo debate público que se

\footnotetext{
${ }^{66}$ Menicucci (2007) chama atenção para o fato de que, apesar de representar uma descontinuidade institucional, o SUS também abarca continuidades com o antigo modelo privatista, especialmente em razão dos efeitos de feedback de políticas prévias e de dependência da trajetória, que resultam em padrões de difícil reversão, o que tende a limitar as possibilidades de mudança (MENICUCCI, 2007, p. 40).

67 A necessidade de um novo modelo da política de segurança pública frente à escalada da violência e às novas formas contemporâneas de criminalidade parece clara. Nas palavras de Kinzo et al. (2004, p. 46): "No horizonte da agenda brasileira dos próximos anos, dificilmente haverá algum outro tema tão urgente para consciência democrática e nacional. A criação de um sistema unificado de segurança pública, ao mesmo tempo eficaz e democrático, capaz de devolver as ruas e os bairros aos cidadãos comuns, aparece hoje como um desafio a todo o sistema político brasileiro".
} 
tem acerca do tema e a própria natureza da política em questão, bastante sensível ao equilíbrio democrático ${ }^{68}$.

${ }^{68}$ Exemplo de sensibilidade dessa arena foi o episódio ocorrido em 16 de outubro de 2008, em São Paulo. Na ocasião, policiais civis em greve protestavam em frente ao Palácio dos Bandeirantes, quando a polícia militar foi chamada para dispersar a manifestação. Vinte e três pessoas ficaram feridas no confronto, inclusive por armas de fogo, em meio a um grande clima de apreensão e incertezas por parte de seus espectadores. Os policiais civis foram armados à manifestação, conforme declarado pelo presidente do Sindicato da Polícia Civil de Campinas e região. Segundo matéria veiculada, no próprio dia 16 de outubro de 2008, na Folha Online, intitulada Confronto entre PMs e policiais civis grevistas deixa 23 feridos em São Paulo, os grevistas eram escoltados por dois grupos de elite da própria polícia civil, o GOE e o GARRA. A direção da Associação dos Delegados de Polícia Civil do Estado de São Paulo, fazendo uso da expressão "guerra", deu a seguinte declaração: "Nós não queremos guerra. O governo [...] quer guerra". Disponível em: <http://www1.folha.uol.com.br/folha/cotidiano/ult95u457102.shtml>. 16 out. 2008. 


\section{Capítulo 5 - Mudanças possíveis: pequenos deslocamentos nas características da política}

Frente à inexistência de uma ampla coalizão reformista, sem a qual não se consegue implementar reformas estruturais na política de segurança pública, quais têm sido as mudanças possíveis?

Como se verá adiante, dadas as dificuldades para se proceder a mudanças estruturais, ocorre um novo tipo de ativismo que provoca pequenos deslocamentos em algumas das características da política, embora estes não sejam potentes para ensejar uma ruptura institucional no modelo vigente. Trata-se de uma nova conformação no campo, decorrente da ampliação dos atores da comunidade da política, que favorece um reformismo incremental, cujo impacto possibilita, entre outras coisas, pequenas alterações na dinâmica federativa da política de segurança pública, embora suas características centrais, como a fragmentação e a dualidade das instituições policiais, continuem preservadas.

O governo federal e alguns governos municipais começaram a pautar a política de segurança pública em suas agendas e a promover algumas inovações nesse campo. Compreender o que torna essas mudanças possíveis parece importante, ainda que não se possa predizer o final desse processo, isto é, se e quando algumas dessas inovações se consolidarão no desenho constitucional da política; se e quando se constituirá uma ampla coalizão que defenda a mudança estrutural do modelo da política, qual o modelo de política em torno do qual ela se construirá e se a mencionada coalizão será potente para fazer prevalecer sua preferência em todos os momentos do processo decisório.

Não obstante a existência de reformas incrementais que vêm sendo implementadas pontualmente em alguns estados ${ }^{69}$, o foco da análise se centrará nas inovações protagonizadas pelos novos atores políticos da comunidade da política de segurança pública, isto é, pelos municípios e pelo governo federal,

\footnotetext{
${ }^{69}$ Para conhecimento de algumas dessas inovações, sobretudo as implementadas nos estados do Amapá, Mato Grosso do Sul e Rio de Janeiro, ver Soares (2002). Para esse autor, a originalidade das novas políticas de segurança propostas por alguns estados consiste no fato de esses governos terem promovido uma associação entre direitos humanos e eficiência policial. É importante notar, no entanto, que esses avanços são pontuais e que, muitas vezes, sofrem descontinuidades e retrocessos, especialmente quando das mudanças de gestão.
} 
especialmente nos governos Fernando Henrique Cardoso e Luiz Inácio Lula da Silva. Pretende-se verificar como executivos municipais e o executivo federal pautam o tema em suas agendas e se as inovações políticas por eles implementadas têm sido capazes de incidir na política de segurança pública de forma a promover deslocamentos no seu desenho.

\subsection{Experiência inovadora dos municípios}

O aumento da violência e da criminalidade nas grandes cidades do mundo, a partir das décadas de 1970 e 1980, tem promovido, como visto no capítulo 4, rupturas nos paradigmas da segurança pública e da criminologia. Partimos, nesta seção, da compreensão de como os atores internacionais e a literatura têm tratado o papel do poder local na prevenção e no controle do crime e da violência para, em seguida, analisarmos qual tem sido, no Brasil, o papel dos governos municipais na área da segurança pública e como experiências municipais inovadoras de prevenção da violência têm influído na formação da agenda do governo federal.

5.1.1 Contextualizando as estratégias locais de prevenção do crime

Os desafios impostos pela criminalidade contemporânea passaram a exigir novos mecanismos políticos administrativos na gestão da segurança (FREY; CZAJWOSKI, 2008). Nessa perspectiva, no marco do paradigma da segurança cidadã, engendram-se novas estratégias locais de prevenção do crime e da violência que implicam a responsabilização e o envolvimento de vários atores estatais e não estatais na coprodução de segurança, por meio de uma gestão compartilhada, multissetorial e integrada, com vistas à redução dos fatores de risco e ao aumento dos fatores de proteção associados ao crime e à violência. Ao lado das ações repressivas e de controle da ordem pública desenvolvidas pelas instituições policiais, coloca-se em relevo também a "preocupação com a qualidade de vida e com a 
dignidade humana em termos de liberdade, acesso ao mercado e oportunidades sociais" (ARRIAGADA; GODOY, 2000, p. 108).

Apesar de ser bastante recente como domínio governamental, essa lógica da gestão local da segurança pública tem ocupado lugar central na agenda de muitas cidades da América Latina e do mundo. Na Colômbia, Chile, Argentina e Equador, por exemplo, várias cidades têm desenvolvido políticas e programas exitosos. Da mesma forma, importantes organizações internacionais já pautaram a prevenção local do crime e da violência como áreas específicas de atuação, como é o caso do Programa Cidades Seguras ${ }^{70}$ do UN-HABITAT (Programa das Nações Unidas para os Assentamentos Humanos) e do Fórum Europeu de Segurança Urbana. O lançamento, em 2002, na cidade de Valparaiso, no Chile, da Rede 14 da URB-AL ${ }^{71}$, denominada "Segurança cidadã na cidade", também reflete a centralidade do tema para as cidades. A Rede 14 reúne municípios da América Latina e Europa, fomentando entre eles o intercâmbio de boas práticas e a realização de projetos conjuntos, com o objetivo de fortalecer a capacidade de gestão dos atores locais na área da segurança urbana. Agências internacionais, como o Banco Mundial e o Banco Interamericano de Desenvolvimento, também atuam no setor disponibilizando linhas de financiamento para o poder público e produzindo pesquisas e materiais didáticos sobre prevenção do crime e da violência e reformas das polícias.

O Manifesto das cidades para a segurança e democracia (2000), do Fórum Europeu de Segurança Urbana, afirma que, para que se possa garantir segurança a cada um, à comunidade e à cidade, é preciso rechaçar "posturas fanáticas, racistas ou práticas discriminatórias". A ideia de cidade a ser firmada deve ser a da cidade de inclusão, hospitaleira, tolerante. Cidade que reforce "os laços de proximidade, de convivência e de comunidade e que produza o sentimento de pertencer a uma cidade comunitária". Cidade de cidadania ${ }^{72}$.

\footnotetext{
${ }^{70} \mathrm{O}$ documento conceitual do Programa Cidades Seguras, intitulado "Un enfoque democrático en matéria de seguridad urbana", situa a prevenção como um dos pilares de toda a luta democrática, consistente em "evitar a criminalidade lutando não apenas contra suas manifestações, senão que sobre o todo, focalizando suas causas".

${ }^{71}$ A URB-AL é um programa de cooperação descentralizado da Comissão Europeia, com o objetivo de construir intercâmbios entre cidades da América Latina e da Europa. Sobre a Rede 14, acesse: $<w w w . u r b a l v a l p a r a i s o . c l>$.

${ }^{72}$ A agenda do Fórum Europeu de Segurança Urbana contrasta com outras agendas, como por exemplo, a de algumas cidades que adotam a política de tolerância zero, que pode contribuir, como afirma Wacquant (2002), para criminalizar e estigmatizar exatamente quem mais sofre com a violência, os pobres e os marginalizados. Segundo o autor, essa política rompe com os laços de
} 
As cidades aparecem, contemporaneamente, como locus privilegiado de uma nova política de prevenção da violência, envolvendo estratégias multissetoriais e a articulação de novos atores, com ampla participação da sociedade civil. Cidade, espaço público e cidadania são conceitos relacionados dialeticamente (BORJA, 2004). A dissolução, fragmentação e privatização são processos negativos que ameaçam a cidade como espaço de afirmação de direitos e de uma nova cidadania $^{73}$. Espaço público, nesse sentido, opõe-se à violência, tal qual no pensamento arenditiano, segundo o qual violência é dominação, é supressão do espaço público, da palavra plural e da capacidade de ação (ARENDT, 2004).

Várias experiências de governança local ${ }^{74}$ e compartilhamento de poder têm sido desenvolvidas em diferentes cidades no mundo, relacionadas à proteção de interesses difusos. Trata-se de uma nova institucionalidade participativa e cooperativa que potencializa diversos saberes, competências, recursos e informações na resolução de problemas comuns, numa abordagem relacional (BURRIS; DRAHOS; SHEARING, 2005; DUPONT, 2004; SCHNEIDER et al., 2003; SLAKMON; OXHORN, 2006).

Slakmon; Oxhorn (2006, p. 32) referem-se à importância da governança da justiça e da segurança em nível local ${ }^{75}$, "principalmente por meio de atores e redes comunitárias $^{76}$, em diferentes tipos de cooperação com agências estatais e atores não estatais". A governança local cooperativa pode potencializar recursos e

solidariedade indispensáveis ao convívio social harmônico, gerando intolerância e, portanto, mais conflitos sociais, exclusão e violência.

${ }^{73}$ Para O'Donnell (2004), uma das formas de se avaliar a qualidade das democracias diz respeito à conexão existente entre democracia, direitos humanos e desenvolvimento humano. Segundo o autor, a base moral comum que conecta intimamente esses três conceitos é a visão que partilham do ser humano. Trata-se de um ser humano cidadão, agente, que fundamenta o novo conceito de cidadania.

${ }^{74}$ Para Ribeiro, Cruz e Batitucci (2003), a ideia de governança consiste nas "condições que garantam a eficiência estatal, envolvendo dimensões sociais e políticas da gestão pública, fenômeno esse que se manifesta através da alteração dos padrões de coordenação e cooperação entre atores sociais, o que ocorre, principalmente, pela transformação das intermediações realizadas pelas instituições do Estado".

${ }^{75}$ Vários estudos têm analisado esse tipo de governança na segurança em diversas partes do mundo. Cartwright e Jenneker (2006) analisam uma experiência de governança local da segurança na África do Sul, e Wood e Marks (2006) estudam o que denominaram de governança conexa (remetendo à ideia de conexão e vínculo) da segurança em Victoria, Austrália.

${ }^{76}$ Parte da literatura sobre governança cooperativa local por meio de redes dialoga com a literatura sobre capital social. Putnam (2007, p. 186) observa que as redes podem promover normas duradouras de reciprocidade generalizada e encorajar a emergência de confiança social, facilitando a coordenação e a comunicação, amplificando reputações e permitindo, dessa forma, que dilemas da ação coletiva sejam resolvidos. Para o autor, a cooperação e a confiança social são estimuladas pelas normas de reciprocidade e pela participação cívica, porque estas "reduzem os incentivos a transgredir, diminuem as incertezas e fornecem modelo para a cooperação futura". 
competências, fomentar a cooperação e a confiança e facilitar o encaminhamento e a implementação das ações a serem adotadas. "The emergence of trust and norms of cooperation based on repeated interactions can foster collective action in policy communities even in the presence of conflicting values and beliefs" (SCHNEIDER, 2003, p. 152).

No caso da política de segurança pública, vários dos problemas a serem enfrentados envolvem múltiplos aspectos e fatores que afetam a coletividade de forma difusa. A complexidade e a multicausalidade da violência demandam uma concepção interdisciplinar, integradora e participativa no desenho das políticas públicas locais de segurança, visando à redução dos índices de criminalidade e à diminuição da insegurança sentida pela comunidade (DAMMERT, 2004, DAMMERT; PAULSEN, 2005; SHAW, s/d; VANDERSCHUEREN, 2005).

A nova prevenção do crime, segundo Dias Neto (1999, p. 116), implica em garantir as condições materiais e simbólicas de segurança, tarefas essas que não podem ser exercidas por uma única instituição:

Em oposição às políticas tradicionais centradas no monopólio das iniciativas estatais, o que se propõe é uma abordagem desde a base, que assuma a tutela do bem coletivo da segurança como uma tarefa que envolve a corresponsabilidade do conjunto das instituições democráticas de um território.

5.1.2 Novos atores, novas agendas: os municípios e a prevenção no Brasil

Historicamente, no Brasil, a segurança pública, como se analisou no capítulo 2, diz respeito às instituições do sistema de justiça criminal, responsáveis pelo controle da lei e da ordem, que atuam dentro de um modelo repressivo-punitivo de enfrentamento e controle do crime. A prevenção, como estratégia do sistema de justiça criminal, insere-se também nesse registro, limitando-se à inibição do ato delituoso, decorrente da presença ostensiva da polícia e da dissuasão como efeito da aplicação da sanção penal.

Ao se considerar a segurança pública à luz dessa lógica exclusivamente repressivo-punitiva, aos municípios resta muito pouco a fazer, uma vez que as instituições às quais competem a manutenção da lei e da ordem, a aplicação da lei 
penal e a execução da pena vinculam-se às esferas estaduais e federal do Estado. Aos municípios, o artigo 144, parágrafo 8², da Constituição Federal, facultou apenas a criação de guardas municipais para a vigilância de seus bens, serviços e instalações.

Por outro lado, a Constituição Federal de 1988 instituiu no Brasil a federação trina ao elevar os municípios à condição de entes federados autônomos. Ao fazer isso, o desenho constitucional possibilitou o aparecimento de novos atores com capacidade de incidir na formulação e na gestão de políticas públicas ${ }^{77}$. Dotados de autonomia, vários municípios têm protagonizado inovações na gestão pública, como o orçamento participativo, programas de renda mínima e programas locais de prevenção da violência. Cada vez mais cobrados pelos índices crescentes de criminalidade em seus territórios, muitos municípios passaram a instituir experiências inovadoras de governança local da segurança, valendo-se de suas competências para a implementação de políticas sociais e urbanas, de seu poder de polícia administrativa, de sua capacidade de mobilização e de seu conhecimento do território.

É fato que, a exemplo do que ocorre em outras políticas públicas, nas quais o papel dos municípios já está inclusive melhor consolidado, há grandes diferenças de atuação nessa área entre os cerca de 5.560 municípios brasileiros. Ainda hoje, há gestores municipais para os quais a segurança local refere-se exclusivamente ao trabalho das guardas municipais (quando existem), sem que se considere a gestão de uma política local articulada de prevenção da violência ${ }^{78}$. Em geral, esses gestores locais ainda não se sentem legitimados como protagonistas de políticas de controle e prevenção do delito porque, para eles, a segurança pública segue sendo de domínio exclusivo das agências policiais estaduais. Os novos arranjos institucionais, na perspectiva do paradigma da segurança cidadã, pretendem exatamente redistribuir as tarefas de prevenção e controle do crime e da violência para além desse domínio. Novas e velhas posturas convivem também entre os executivos municipais, mas as inovações municipais e as articulações que elas

77 Para Pierson (1995), a emergência de unidades constituintes da federação como novos atores políticos significativos é um dos efeitos institucionais do federalismo. Outros dois efeitos seriam mudanças nas preferências políticas, nas estratégias e na influência dos atores e dilemas relativos à divisão da autoridade decisória entre múltiplas jurisdições.

${ }^{78}$ Além disso, a inexistência de uma cultura matricial de gestão na administração pública dificulta, ainda mais, a proposição e a coordenação de políticas públicas integradas e multissetoriais, que caracterizam as políticas preventivas da violência. 
promovem já se mostram potentes para mostrar a relevância desses novos atores, como se viu no capítulo anterior.

Instância de governo mais próxima da população, o município tem competência e instrumentos para a implementação de políticas preventivas fundamentais, embora insuficientes, para um provimento mais adequado da segurança pública, como é amplamente reconhecido pelos atores pesquisados. $\mathrm{Na}$ perspectiva da análise constitucional, os municípios estão autorizados a atuar na área da segurança pública por força do disposto no caput do artigo 144, da Constituição Federal, que responsabiliza todos pelo provimento da segurança, e do disposto em seu artigo 23, inciso I, segundo o qual é competência comum aos três entes federados zelar pela guarda da Constituição, das leis e das instituições democráticas e conservar o patrimônio público. Desenvolver políticas que possam não apenas reprimir a violência (atribuição exclusiva das polícias federal e estaduais), mas que possam preveni-la é dever da União, dos estados e também, especialmente, pela natureza de suas competências, dos municípios.

Desde há muito, os municípios colaboram, principalmente com recursos materiais, com as polícias estaduais alocadas em seus territórios. É comum, como já se mencionou anteriormente, que o município se responsabilize por despesas com aluguel de imóveis, cessão de próprios, combustível para as viaturas, tanto da polícia militar como da polícia civil. O que é novo é a centralidade que a segurança assumiu na agenda de vários municípios, que passaram a atuar como gestores, a partir de suas competências específicas, no âmbito do controle e da prevenção do crime e da violência.

Aos poucos, especialmente nos últimos dez anos, os municípios foram instituindo estruturas próprias para a gestão da prevenção e controle do crime e da violência. A segurança pública foi sendo pautada na agenda de muitos executivos municipais, que chamaram para si a atribuição de formular políticas preventivas e de, complementarmente às competências das polícias estaduais, capacitar suas guardas municipais para uma atuação preventiva e comunitária. Pesquisa do IBGE (2007) sobre o perfil dos municípios brasileiros indica que 1.230 municípios brasileiros (ou seja, 22,1\% do total de 5.564 municípios) possuem estrutura organizacional específica para tratar de assuntos relacionados à segurança pública. Em 445 municípios (8,\% do total de municípios brasileiros), já existem conselhos 
municipais de segurança, em geral com representação do poder público, em vários níveis, e da sociedade civil.

Experiências recentes de governança local da segurança em municípios brasileiros têm se mostrado exitosas ${ }^{79}$. No estado de São Paulo, por exemplo, vários municípios instituíram, nos últimos anos, órgãos gestores da política de segurança urbana, como é o caso de Diadema, Guarulhos, São Paulo, Santo André e Campinas. Diversas experiências inovadoras têm sido implementadas e reconhecidas por especialistas da área, como o Programa de Comissões Civis Comunitárias $^{80}$, desenvolvido no município de São Paulo entre os anos de 2002 e 2004, a política integrada de segurança de Diadema, em curso desde 2001, os Programas Santo André Mais Segura e Santo André Mais Igual, desenvolvidos em Santo André, de 2001 a 2008, todos baseados na governança local, numa lógica proativa, na multissetorialidade e no compartilhamento da gestão com a própria comunidade e com outros atores não estatais.

Merece destaque a emblemática experiência de Diadema, que foi um dos primeiros municípios que inovou na área da prevenção do crime, atuando de maneira integrada com outros níveis de governo. Marcada por violência notabilizada em todo o Brasil, não apenas em razão das estatísticas criminais, mas também por ter sido palco de um dos flagrantes mais brutais de violência policial, ocorrido na Favela Naval, em 1997, Diadema pautou a segurança urbana como prioridade na sua agenda governamental ${ }^{81}$.

Cidade industrial da região metropolitana de São Paulo, Diadema ocupava, no ano 2000, o $7^{0}$ lugar no ranking nacional de mortes violentas, passando a ocupar a 40ํำ posição no ano de 2005. O gráfico abaixo mostra a evolução dos casos de homicídio na cidade entre os anos de 1996 e 2005 (taxa por 100 mil habitantes):

\footnotetext{
79 Algumas dessas experiências, como as desenvolvidas em Vitória, Recife, Porto Alegre, Santo André, Diadema e São Paulo, estão retratadas em Sento-Sé (2005).

${ }^{80}$ Sobre o programa de Comissões Civis Comunitárias ver também Gonçalves (2004).

${ }^{81}$ Vale notar que Diadema foi a única cidade da região metropolitana de São Paulo em que o "sim" ao referendo sobre a proibição do comércio de armas e munição, ocorrido em outubro de 2005, foi vencedor. Ao contrário do que se poderia pensar, em uma cidade que foi por tantos anos símbolo de município violento, o medo parece não ter conduzido seus moradores a uma postura majoritariamente defensiva e reativa, apontando para uma preferência pelas formas não violentas de resolução de conflitos. Em Diadema, as campanhas de desarmamento, ao lado da Lei Seca, foram um dos principais programas preventivos do governo, entre os anos de 2001 e 2008.
} 


\section{Evolução dos casos de homicídio em Diadema (1996-2005)}

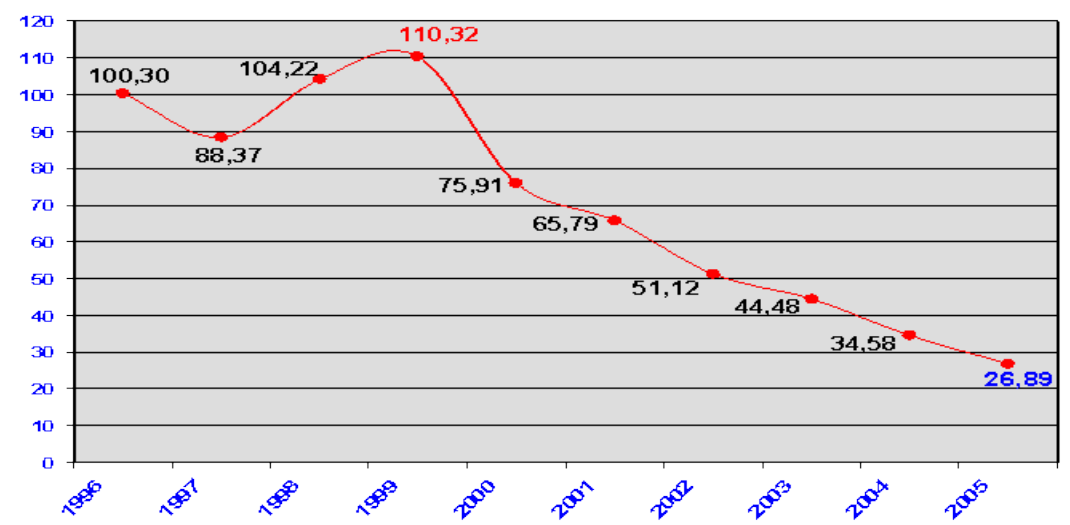

Fonte: Secretaria de Defesa Social de Diadema

Desde o ano 2000, o Executivo Municipal instituiu a Secretaria de Defesa Social, o Fundo Municipal de Segurança e o Conselho Municipal de Segurança e deu início a um processo inédito de mapeamento e geoprocessamento dos crimes no município. Além disso, iniciou um processo de diálogo com diversos setores da sociedade, como o que precedeu a instituição da chamada Lei Seca, que visava a regular as atividades de bares e outros estabelecimentos similares, restringindo seu horário de funcionamento. Vale destacar que o então prefeito, José de Felipe Júnior, que governou a cidade por dois mandatos (2000-2003 e 2004-2008) conduzia, pessoalmente, todas as reuniões do Conselho Municipal de Segurança Urbana, reafirmando continuamente a centralidade do tema na agenda do Executivo Municipal e contribuindo, dessa forma, para garantir uma potente integração entre os órgãos municipais e as agências estaduais de segurança pública.

Os órgãos gestores municipais de segurança têm se responsabilizado pela gestão de projetos locais preventivos, desde uma perspectiva epidemiológica da violência, em que importa atuar de maneira intersetorial, integrada, participativa e coordenada, objetivando diminuir os fatores de risco e aumentar os fatores de proteção. Os programas locais de prevenção do crime e da violência, desde essa nova perspectiva, não se subsumem à política macrossocial, mantendo particularidades e consubstanciando conceito próprio, que envolve a requalificação dos espaços públicos, a prevenção social e situacional, a mediação de conflitos, a gestão de informações, o enfrentamento de fatores e dinâmicas de risco, como o uso 
abusivo de álcool, drogas e a disponibilidade de armas de fogo, a promoção da cultura da paz e o fortalecimento de canais de participação.

As inovações municipais no campo da segurança pública foram reconhecidas especialmente no Governo Lula. Logo no início de seu primeiro mandato, o Comitê de Articulação Federativa (CAF), vinculado à Presidência da República, pautou a atuação dos municípios no campo da segurança pública e promoveu várias discussões que foram, ao final, sistematizadas em um documento intitulado "A Segurança Pública e o Município" (FRENTE NACIONAL DE PREFEITOS, 2004). Nele se reconhece que as experiências municipais exitosas ainda exigem a construção de uma base consistente e consensual acerca de uma política nacional para a segurança municipal, motivo pelo qual o documento propõe princípios e diretrizes gerais para a atuação dos municípios na política de segurança. A vocação essencial dos municípios, expressa o documento, é a de desenvolver, a partir de diagnósticos locais consistentes, estratégias preventivas que combinem uma atuação comunitária de suas guardas municipais com a adoção de ações sociais e urbanas focadas nas áreas, grupos e dinâmicas de grande incidência de violência, preservando-se a ordem urbana, com fiscalização, ainda, das posturas municipais. Essa atuação, ressalta o texto, deve se dar de forma sistêmica, "em sintonia e cooperação com as demais instâncias federativas, sobretudo com os órgãos policiais e de justiça criminal".

Posteriormente, já no curso do segundo mandato do presidente Lula, as inovações municipais mostraram-se importantes para a configuração do Programa Nacional de Segurança Pública com Cidadania - Pronasci ${ }^{82}$, que reconhece e incorpora, em programa nacional, o protagonismo municipal na prevenção da violência. Até setembro de 2009, 106 municípios brasileiros já haviam aderido ao Pronasci, recebendo recursos destinados a projetos preventivos endereçados a territórios vulneráveis (Anexo D).

No que diz respeito às guardas municipais, estima-se que haja no Brasil pouco menos de 800 municípios com guardas instituídas, concentradas, sobretudo, nos estados da Bahia, São Paulo, Pernambuco, Rio de Janeiro e Ceará, totalizando

\footnotetext{
${ }^{82}$ O Pronasci será analisado mais detalhadamente na seção 5.3 deste capítulo.
} 
um efetivo de aproximadamente 75 mil guardas em todo o país ${ }^{83}$. Uniformizadas e, parte delas, $\operatorname{armadas}^{84}$, as guardas municipais carecem de uma regulamentação nacional, o que faz com que essa instituição não tenha conseguido, até hoje, construir uma identidade nacional ${ }^{85}$. Grande parte delas, para além da proteção dos próprios públicos, vem capacitando seu efetivo, de acordo com a matriz curricular elaborada nos anos 2004-2005, pela SENASP, para uma atuação preventiva. Segundo o preâmbulo da Matriz Curricular Nacional para formação das Guardas Municipais,

[...] as funções e atribuições das Guardas municipais ampliaram, na prática, aquelas previstas no artigo 144 da Constituição Federal, que se limitam à proteção dos bens, serviços e instalações municipais. Elas se multiplicaram ao longo dos anos acompanhando o crescimento das cidades e a complexidade dos problemas de urbanização. A prevenção constitui, hoje, a principal missão da guarda municipal e pode assumir diferentes formas, exigindo também modos operacionais diversificados, segundo o tipo de Município aonde [sic] atua.

Como visto na análise do questionário respondido pelos atores, feita no capítulo anterior, embora um número significativo de atores defenda uma atuação preventiva por parte das guardas, existem posições diversas e polarizadas, indicando a necessidade de maior debate sobre o desenho que a instituição deve assumir numa eventual reforma constitucional. Além disso, há o reconhecimento institucional, expresso pelo texto da Matriz Curricular Nacional, de que não há mais como limitar as atribuições das guardas àquelas estritamente mencionadas no artigo 144, da Constituição Federal.

Em síntese, apesar das políticas locais de segurança pública ainda não terem sido pautadas pela totalidade dos municípios brasileiros, estes têm sido cada vez mais reconhecidos como novo ator da comunidade dessa política, tanto pelo

\footnotetext{
${ }^{83}$ Segundo pesquisa do IBGE (2007), 14,1\% dos municípios brasileiros possuem guardas municipais, especialmente concentradas nas cidades com mais de 500 mil habitantes $(77,8 \%$ dos municípios desse grupo possuem sua guarda).

${ }^{84}$ Pelo fato de serem uniformizadas, e muitas delas armadas, as guardas municipais são, em geral, identificadas pela população como força policial. Note-se, por exemplo, que no episódio de maio de 2006, em São Paulo, em que agentes públicos de segurança foram atacados por membros do Primeiro Comando da Capital (PCC), várias bases comunitárias de guardas municipais foram também alvo da ação da organização criminosa.

${ }^{85}$ Ainda que não se considere uma eventual mudança constitucional no papel e atribuições das guardas, o artigo 144, parágrafo $8^{\circ}$, da $C F$, faz alusão a uma regulamentação que, até hoje, não foi feita. A regulamentação nacional das guardas civis municipais é importante para conferir a essa instituição uma identidade nacional e, sobretudo, para possibilitar maior controle social e continuidade na prestação do serviço, para além das preferências de cada prefeito eleito.
} 
governo federal quanto por outros atores. Vários municípios brasileiros inovaram e seguem construindo sua política municipal de segurança em duas frentes articuladas. A primeira se relaciona à nova governança local da segurança para a gestão de projetos de prevenção da violência, multissetoriais, integrados e participativos. A segunda, no caso dos municípios que possuem Guarda Municipal, por meio também da especialização de seu efetivo para o policiamento preventivo e comunitário. $O$ protagonismo dos executivos municipais na segurança pública brasileira é um fato novo na história dessa política, que altera, de maneira inequívoca, sua dinâmica federativa.

5.2 Governo FHC: marco inaugural da inclusão da política de segurança na agenda federal

A principal finalidade desta seção é apontar como o tema da segurança pública, como política nacional, entrou, pela primeira vez em período democrático, para a agenda do Executivo Federal. Durante os dois e sucessivos governos do presidente Fernando Henrique Cardoso (1995 a 1998 e 1999 a 2002) foram criados a Secretaria Nacional de Segurança Pública (SENASP) e o Fundo Nacional de Segurança Pública (FNSP). Foi lançado também o primeiro Plano Nacional de Segurança Pública (PNSP), que, apesar de mal ter saído do papel e de não ter logrado os resultados pretendidos, foi a primeira tentativa de uma política articulada de segurança pública nos três níveis de governo.

5.2.1 Agenda, contexto e criação da Secretaria Nacional de Segurança Pública

O Programa de Governo com o qual o presidente Fernando Henrique Cardoso se elegeu em 1994, intitulado "Mãos à Obra" (CARDOSO, 1994), não pautava reformas estruturais nas instituições policiais, mas prometia o controle da criminalidade, em todas as suas formas, e a aplicação rigorosa da lei. O programa 
estabelecia quatro linhas de ação. Duas delas relativas à democratização do acesso ao Poder Judiciário e ao aperfeiçoamento do sistema penitenciário; uma visando ao fortalecimento dos órgãos federais de segurança (Polícia Federal e Polícia Rodoviária Federal) e a outra visando a uma maior cooperação intergovernamental.

Nesta última linha de ação, o Programa de Governo propunha a criação da Secretaria Nacional de Segurança Pública, no âmbito do Ministério da Justiça; a articulação dos três níveis de governo, incluindo a integração das ações de prevenção e repressão do crime na esfera local; valorização profissional do policial, por meio de formação, aperfeiçoamento e especialização; a implantação de um programa de integração das informações criminais; a intensificação das operações conjuntas entre polícias federais e estaduais e a formulação de uma nova política de assistência aos usuários de drogas ilícitas.

Analisando a política de segurança pública do primeiro governo FHC, Adorno (1999) chama a atenção para a centralidade da agenda dos direitos humanos ${ }^{86}$. Segundo Alvarez, Salla e Souza (2004), desde os anos 1980, direitos humanos são um tema chave para se compreender a formação da agenda de segurança pública no país. De fato, os dois mandatos presidenciais de FHC foram marcados por uma profunda mobilização nacional no campo dos direitos humanos (tanto de atores defendendo esses direitos como de atores a eles reagentes).

A tônica dos dois governos referiu-se muito mais à ampla temática dos direitos humanos do que à segurança pública especificamente, embora ambas as políticas estejam inelutavelmente imbricadas. Foram lançados dois Programas Nacionais de Direitos Humanos (PNDH), um em 1995 e outro no ano $2000^{87}$, e vários tratados e convenções internacionais de direitos humanos foram ratificados pelo governo brasileiro no período ${ }^{88}$. Inúmeras ações de segurança pública estão incluídas nos PNDHs. O segundo PNDH previa, por exemplo, o apoio à execução do Plano Nacional de Segurança Pública, o apoio a programas preventivos da violência voltados para grupos vulneráveis; a ampliação de programas para redução da

\footnotetext{
${ }^{86}$ Adorno (1999) observa que, apesar da mencionada centralidade, não se logrou convencer o cidadão de que a observância e a garantia desses direitos são requisitos essenciais à segurança pública.

87 Sobre o tema ver Adorno (1999; 2003), Pinheiro (1999) e Mesquita Neto e Affonso (2002).

88 É o caso, por exemplo, da aceitação da competência da Corte Interamericana de Direitos Humanos, em 1998, seis anos depois da ratificação da Convenção Americana sobre Direitos Humanos pelo Brasil; da ratificação do Protocolo de São Salvador (1999), do Protocolo Facultativo à Convenção sobre a eliminação de todas as formas de discriminação contra a Mulher (2002), e da aceitação da competência do Tribunal Penal Internacional (2002), entre vários outros.
} 
violência nas escolas; a criação de programas de atendimento psicossocial para o policial e sua família; o fortalecimento do Fórum Nacional de Ouvidores e a criação da Ouvidoria da Polícia Federal ${ }^{89}$. No ano de 1997, iniciou-se uma intensa mobilização nacional em torno da questão do desarmamento, que, em dezembro de 2003, resultou na aprovação do Estatuto do Desarmamento (Lei n. 10.826, de 22 de dezembro de 2003) $)^{90}$.

Durante os dois governos do presidente Fernando Henrique Cardoso, cresceram as taxas de criminalidade e persistiram os casos emblemáticos de violência policial. Massacres como o de Vigário Geral e da Candelária, em 1993, continuaram ocorrendo. A chacina de Corumbiara, em 1995, o massacre de integrantes do movimento dos sem-terra em Eldorado dos Carajás, no ano seguinte, e o já citado caso da Favela Naval, em 1997, produziram momentos de crise. Em todos esses episódios, agentes públicos de segurança, responsáveis pela manutenção da lei e da ordem, figuravam como violadores de direitos fundamentais. Algumas dessas conjunturas críticas acabaram por criar janelas de oportunidade para a implementação da agenda governamental e para a aprovação de projetos de lei que, de outra forma, talvez não tivessem ocorrido naquele momento em que a disputa de agendas se dava de forma bastante polarizada entre atores que pretendiam mudanças na política de segurança pública e que defendiam a garantia dos diretos humanos e atores conservadores com agendas reagentes àquelas.

Foi o que sucedeu no episódio da chacina de 19 sem-terra por policiais em Eldorado dos Carajás, em 1996. Logo após o massacre, seguindo expressa determinação de FHC, o então Ministro da Justiça, Nelson Jobim, foi ao Congresso Nacional fazer gestões para a aprovação de um Projeto de Lei do deputado Hélio Bicudo, que já se encontrava em tramitação há algum tempo, propondo a eliminação do foro privilegiado para crimes cometidos por policiais militares contra civis, na função de policiamento (ZAVERUCHA, 2002). Esse projeto foi rapidamente aprovado pela Câmara, com a ressalva anacrônica de que as investigações

\footnotetext{
${ }^{89}$ Até outubro de 2009, a Ouvidoria da Polícia Federal ainda não havia sido criada, apesar de ter sido pautada também pelo Governo Lula.

90 Segundo dados do Sistema de Informações sobre Mortalidade (SIM), do Ministério da Saúde, a taxa de mortalidade por armas de fogo no Brasil cresceu 21,6\% de 1979 a 1999. Em 1999, as mortes por arma de fogo foram responsáveis por $42 \%$ dos óbitos de jovens do sexo masculino com idades entre 15 e 19 anos (PERES, 2004). Dois anos após a aprovação do Estatuto, em 23 de outubro de 2005, ocorreu o referendo sobre a proibição ou não da comercialização de armas de fogo e munições no Brasil, vencendo a proposta da não-proibição.
} 
continuariam a ser realizadas por inquérito policial militar, ou seja, pelos próprios policiais militares. Submetido ao Senado, o projeto original sofreu novo golpe, tendo sido aprovado, em agosto de 1996, que apenas os crimes dolosos contra a vida cometidos por policiais militares passariam a ser julgados pelo Tribunal do Júri, saindo da esfera de competência da Justiça Militar. Pouco tempo depois, em fevereiro de 1997, foi aprovada também a lei que tornou crime o porte ilegal de armas e que criou o Sistema Nacional de Armas (SINARM).

Em 31 de março de 1997, cenas veiculadas por toda a grande mídia de policiais militares cometendo crimes contra cidadãos comuns na Favela Naval, em Diadema, novamente desencadearam reações por parte do governo federal e várias propostas importantes, já pautadas anteriormente, foram concretizadas. O projeto de lei tipificando o crime de tortura no ordenamento jurídico brasileiro, que tramitava desde agosto de 1994, foi aprovado em regime de urgência pelo Senado Federal em 3 de abril, no dia seguinte à divulgação do caso, e foi sancionado três dias depois pelo presidente da República. No dia 4 de abril, a Comissão de Constituição e Justiça da Câmara aprovou emenda constitucional federalizando os crimes contra os direitos humanos.

No dia 6 de abril de 1997, foi criada a Secretaria Nacional de Direitos Humanos, que já havia sido anunciada em março e tinha sua instituição prevista para o dia 13 de maio. Imediatamente após a criação da Secretaria Nacional de Direitos Humanos, o presidente Fernando Henrique Cardoso determinou a José Gregori, então Secretário Nacional de Direitos Humanos, a criação de um grupo de trabalho para discutir a reestruturação das polícias (Portaria n. 369/97), abrindo um processo de discussão sobre a unificação das polícias militar e civil. No entanto, segundo Zaverucha (2003), a composição do grupo privilegiava mais o Exército do que a própria representação dos policiais. Pouco depois, em julho de 1997, uma série de greves de policiais militares em diversos estados ofuscou os trabalhos do grupo e nenhuma alteração na estrutura organizacional das polícias foi levada a cabo.

Ainda em 1997, cumprindo uma das metas de seu Programa de Governo, o presidente FHC criou a Secretaria Nacional de Segurança Pública (SENASP), em lugar da extinta Secretaria de Planejamento de Ações Nacionais de Segurança Pública, criada em 1995, logo no início do governo, com a finalidade de cuidar dos 
assuntos referentes à segurança, entorpecentes e trânsito. Segundo consta do decreto de instituição da SENASP ${ }^{91}$, a Secretaria tem por objetivo assessorar o ministro da Justiça na definição e na implementação da política nacional de segurança pública, acompanhando as atividades dos órgãos responsáveis pela segurança pública em todo o território nacional, por meio de diversas ações, que incluem, entre outras, o apoio à modernização do aparelho policial; a ampliação do Sistema Nacional de Informações de Justiça e Segurança Pública (INFOSEG); a efetivação do intercâmbio de experiências técnicas e operacionais entre os serviços policiais federais e estaduais; a implementação do registro da identidade civil; o estímulo à capacitação dos profissionais da área de segurança pública; a gestão dos fundos federais dos órgãos a ela subordinados; o incentivo à atuação dos conselhos regionais de segurança pública; a realização de estudos e pesquisas e consolidação das estatísticas nacionais de crimes, trânsito e entorpecentes.

O Programa de Governo para o segundo mandato de FHC, denominado "Avança Brasil" (CARDOSO, 1998), manteve alguns compromissos anunciados no primeiro programa, no que diz respeito ao fortalecimento da prevenção e da repressão ao crime, à gestão da informação e à valorização do policial, mas reduziu a articulação governamental nos três níveis de governo à integração dos serviços das polícias e das guardas municipais ${ }^{92}$. Chamam a atenção duas inovações relativas ao segundo programa $A$ primeira refere-se à luta pela aprovação da proposta de emenda constitucional que confere aos estados maior liberdade para organizar seus sistemas de segurança pública (PEC 514/97), que, como se viu no capítulo anterior, a exemplo de todas as outras propostas de reformas estruturais formuladas por diferentes atores, não logrou êxito. A segunda iniciativa programática inovadora dizia respeito a "aprofundar os debates para a formulação da Política Nacional de Segurança Pública, que deverá fortalecer as secretarias, os conselhos regionais e o Conselho Nacional de Segurança Pública" (o que só começou a ocorrer no segundo mandato do presidente Lula, como se verá na seção 5.3, deste capítulo).

\footnotetext{
${ }^{91}$ Decreto n. 2.315, de 4 de setembro de 1997.

${ }^{92}$ Apenas quando da elaboração do Plano Nacional de Segurança Pública, em 2000, a concepção mais integradora dos três níveis de governo, presente no primeiro Programa de Governo, foi retomada.
} 
Para Adorno (1999; 2003), a analise da política de segurança pública nos dois mandatos de FHC aponta vários constrangimentos à execução das linhas de ação fixadas nos respectivos Programas de Governo. A violência crescia em diversas direções, em meio a um legado autoritário das instituições de segurança pública e a uma forte polarização na opinião pública, pró e contra a defesa dos direitos humanos, muitas vezes acirrada pela mídia. Nesse contexto, não se chegou a um consenso mínimo sobre como deveria ser implementada a lei e a ordem. As resistências a mudanças mostraram-se "fortes e atuantes", mas contra elas o "governo federal agiu com pouco interesse e eficiência" (ADORNO, 2003, p. 137). Além disso, segundo o autor, estiveram presentes outros constrangimentos políticoinstitucionais, decorrentes tanto das alianças de sustentação política do governo quanto de interesses poderosos herdados do período autoritário e incrustados na burocracia estatal, ocupando espaços decisórios. Nos oito anos de governo FHC, nove diferentes ministros estiveram à frente do Ministério da Justiça, "centro nevrálgico da política de segurança"93. Durante quase todo esse período, a SENASP foi dirigida por oficiais militares ${ }^{94}$.

Havia também os constrangimentos decorrentes do próprio pacto federativo, que confere grande autonomia aos estados na execução de suas políticas de segurança, além da difícil questão, como aponta Adorno (1999), sobre a natureza do controle da segurança:

Os governos estaduais após a abertura do regime tiveram de enfrentar delicadíssimo problema político, até hoje mal equacionado: 0 de reenquadrar suas polícias militares e reconquistar o controle civil da segurança. Eis aqui, desde já, um dos principais constrangimentos ao êxito da política de segurança do governo FHC. (ADORNO, 1999, p. 133)

Nas seções seguintes, serão analisadas duas outras iniciativas implementadas no segundo Governo FHC, mais importantes pelo que representam em termos de agenda governamental visando à construção de uma política nacional, do que propriamente pelos resultados alcançados.

\footnotetext{
${ }^{93} \mathrm{O}$ Ministério da Justiça foi frequentemente usado como moeda de troca entre os partidos da base de sustentação do governo, especialmente o PMDB, como aponta Adorno (2003).

${ }_{94}$ Apenas durante o curto tempo em que José Carlos Dias ocupou o cargo de Ministro da Justiça do Governo FHC é que o comando da SENASP foi desmilitarizado, voltando a ser dirigida por um coronel militar da reserva quando José Gregori substituiu José Carlos Dias.
} 


\subsubsection{Plano Nacional de Segurança Pública - PNSP}

Em junho de 2000, ocorreu o episódio que ficou conhecido como "ônibus 174", na cidade do Rio de Janeiro ${ }^{95}$. O fato acelerou, no segundo mandato do presidente $\mathrm{FHC}$, a formatação e a aprovação do primeiro Plano Nacional de Segurança Pública do período democrático. Segundo Soares (2007, p. 83), logo após o sequestro do ônibus, o presidente da República determinou que o Plano fosse concluído, apresentando-se, finalmente, qual seria a agenda nacional para a segurança. Para o autor, no entanto, o lançamento antecipado do Plano fez com que ele viesse a público, pouco tempo depois, como uma "listagem assistemática de intenções heterogêneas".

O Plano tinha por objetivo o aperfeiçoamento do sistema de segurança pública brasileiro por meio da integração entre políticas de segurança, políticas sociais e ações comunitárias. Propunha aliar medidas repressivas e preventivas visando à redução da impunidade, ao aumento da segurança e à tranquilidade do cidadão. Foram previstas 124 ações que se estruturavam em torno de 15 compromissos, divididos em medidas no âmbito do governo federal, no âmbito da cooperação do governo federal com os governos estaduais, além de medidas de natureza normativa e de natureza institucional, estas últimas relativas à implantação de um sistema nacional de segurança pública.

As medidas no âmbito do governo federal referiam-se a seis compromissos: a) combate ao narcotráfico e ao crime organizado; b) desarmamento e controle de armas; c) repressão ao roubo de cargas e melhoria da segurança nas estradas; d) implantação do subsistema de inteligência de segurança pública; e) ampliação do Programa de Proteção a Testemunhas e Vítimas de Crime; f) regulamentação: mídia $x$ violência.

As medidas no âmbito da cooperação do governo federal com os governos estaduais compreendiam sete compromissos: a) redução da violência urbana; b)

95 O caso ocorreu em 12 de junho de 2000. Sob a mira de um revólver, Sandro Barbosa do Nascimento, uma das vítimas da chacina da Candelária acontecida anos antes, manteve, por cerca de cinco horas, diversos reféns dentro de um ônibus urbano da linha "174". Ao final, uma das reféns acabou morta no momento em que um policial do Batalhão de Operações Policiais Especiais (BOPE) atirou contra o sequestrador. Este, por sua vez, foi detido e, segundo laudo pericial, acabou morto por asfixia. 
inibição de gangues e combate à desordem social; c) eliminação de chacinas e execuções sumárias; d) combate à violência rural; e) intensificação das ações do Programa Nacional de Direitos Humanos; f) capacitação profissional e reaparelhamento das polícias; g) aperfeiçoamento do sistema penitenciário.

Para os especialistas, faltava ao Plano Nacional de Segurança Pública uma definição de prioridades, de metas quantificadas, bem como de estratégias que pudessem articular cada uma das 124 ações previstas, de forma sistêmica (CANO, 2006; LEMGRUBER, 2000; MUNIZ; ZACCHI, 2005; SOARES, 2007).

Em 2001, foi criado o Plano de Integração e Acompanhamento dos Programas Sociais de Prevenção da Violência (PIAPS), vinculado ao Gabinete de Segurança Institucional do Presidente da República. Vinculado a uma das 124 ações previstas no PNSP, o PIAPS tinha por objetivo promover a interação local e o fortalecimento de programas sociais preventivos da violência nas três esferas de governo, fomentando e coordenando as redes locais.

Esse plano foi a primeira iniciativa de construção de um programa autônomo para a coordenação de ações preventivas da violência em algumas áreas metropolitanas, com foco nas crianças e jovens na faixa etária entre 0 e 24 anos. Por meio de convênios firmados entre governos estaduais e municipais, foram priorizadas inicialmente as regiões metropolitanas de São Paulo, Rio de Janeiro, Vitória e Recife e, no segundo ano, foram incorporadas as regiões de Fortaleza, Cuiabá e Distrito Federal. Porém, o PIAPS acabou enfrentando diversos obstáculos na sua execução, não apenas em razão de não contar com recursos próprios, mas porque, sem esse orçamento, faltava-Ihe um mandato efetivo para seu papel de agente articulador e potencializador de iniciativas de outros ministérios (MUNIZ; ZACCHI, 2005).

Dois anos após o lançamento do PNSP, o governo reconheceu que grande parte das medidas previstas não era passível de execução imediata ${ }^{96}$. Segundo Adorno (2003), algumas das medidas eram mais exequíveis de imediato e outras dependiam de maior empenho governamental para convencer opositores e superar as críticas. Para o autor, a marca do Governo FHC na área de segurança pública foi

\footnotetext{
${ }^{96}$ É o que consta da matéria publicada no jornal O Estado de S. Paulo, em 29 de janeiro de 2002, intitulada "Governo vai mudar plano de segurança de novo". Segundo a matéria: "Dos 124 itens do programa, lançado em 2000, pelo Ministério da Justiça, pelo menos oitenta são considerados irrelevantes para adoção imediata".
} 
a de possuir uma elevada capacidade de formulação de políticas, com uma baixa capacidade de implementação (ADORNO, 2003, p. 130).

Embora o PNSP não tenha logrado alcançar os resultados que se propunha, pouco tendo sido implementado na prática, representou um passo inicial na matéria, com pauta que incluía, entre outros itens, a qualificação policial, o estímulo à criação de ouvidorias de polícia, a prevenção e a integração governamental.

\subsubsection{Criação do Fundo Nacional de Segurança Pública}

O Fundo Nacional de Segurança Pública foi instituído em 2001, com o objetivo de financiar projetos na área de segurança pública e deveria servir também de instrumento indutor de políticas adequadas pelas unidades subnacionais. Conforme disposto na lei de instituição do FNSP (Lei nº 10.201, de 14 de fevereiro de 2001), seus recursos deveriam ser repassados a estados e municípios que se comprometessem a: realizar diagnóstico dos problemas de segurança pública, apresentando as respectivas soluções; desenvolver ações integradas entre os diversos órgãos de segurança pública; qualificar as polícias civis e militares, corpos de bombeiros militares e as guardas municipais; reduzir a corrupção e a violência policiais; reduzir a criminalidade e a insegurança pública; reprimir o crime organizado. Os estados também deveriam, como pré-requisito para a liberação de recursos do Fundo, apresentar seus planos estaduais de segurança pública, observadas as diretrizes do Plano Nacional de Segurança Pública.

Pesquisa do IPEA (2003) aponta que, de modo geral, a partir do ano 2000, o governo federal passou a gastar mais com segurança pública: 


\section{Valores totais anuais da execução orçamentária e financeira das despesas da área de segurança}

\begin{tabular}{|c|cc|}
\hline ANO & \multicolumn{2}{|c|}{ VALOR TOTAL } \\
\hline 1995 & $\mathrm{R} \$ 126.433 .974,00$ \\
\hline 1996 & $\mathrm{R} \$ 171.482 .581,00$ \\
\hline 1997 & $\mathrm{R} \$ \quad 242.994 .957,00$ \\
\hline 1998 & $\mathrm{R} \$ \quad 268.754 .762,00$ \\
\hline 1999 & $\mathrm{R} \$ 144.305 .998,00$ \\
\hline 2000 & $\mathrm{R} \$ \quad 762.929 .432,00$ \\
\hline 2001 & $\mathrm{R} \$ 1.009 .498 .398,00$ \\
\hline 2002 & $\mathrm{R} \$ \quad 871.497 .962,00$ \\
\hline
\end{tabular}

Fonte: IPEA (2003)

Analisando a execução orçamentária do Ministério da Justiça, de 1995 a 2002, a mesma pesquisa aponta que, entre 1995 e 1999, os gastos eram voltados para pagamento de pessoal e de outras despesas correntes. Com a instituição do Fundo Nacional de Segurança Pública, foram adicionados, em 2000 e 2001, R\$ 252 milhões e R\$ 397 milhões, respectivamente, aos programas de combate à violência e à criminalidade.

Por outro lado, a pesquisa ressalta que, apesar do FNSP ter sido implementado em momento importante, quando os estados passavam por fortes limitações de recursos, o Fundo apenas permitiu que os estados reproduzissem o velho modelo institucional vigente, como se o problema da segurança pública pudesse ser reduzido a um mero problema de insuficiência de recursos. "Não foram discutidos diagnósticos e eficiência da polícia no Brasil, tampouco se debateu amplamente um modelo de reestruturação das instituições policiais" (IPEA, 2003).

Nos anos 2001 e 2002, o governo federal repassou recursos do FNSP aos entes federados, no valor total de $R \$ 725.683 .611,17$ distribuídos de acordo com as seguintes rubricas orçamentárias: intensificação de policiamento ostensivo em áreas críticas, reaparelhamento das polícias, treinamento e policiamento comunitário. Dos recursos empenhados, quase $88 \%$ foram gastos nas duas primeiras rubricas mencionadas, que abarcam a aquisição de equipamentos, reforma e construção e aquisição de viaturas, munição e armamento. A rubrica "policiamento comunitário" 
consumiu $22,4 \%$ dos recursos no biênio mencionado e a rubrica "treinamento" $1,3 \%$. Segundo Muniz e Zacchi (2005), as quatro rubricas referidas, orientadoras do Fundo até o ano de 2003, denotam uma lógica fragmentária e desarticulada de segurança pública e a destinação majoritária dos recursos evidencia a reiteração de procedimentos de rotina das instituições policiais.

Com o mesmo entendimento, Soares (2007) afirma que a ausência de uma política nacional sistêmica e a dispersão reativa das decisões acabou por repetir velhos procedimentos varejistas, destinando-se os recursos do FNSP principalmente à compra de armas e viaturas ${ }^{97}$. Na avaliação de Soares, "alimentaram-se estruturas esgotadas, beneficiando políticas equivocadas e tolerando o convívio com organizações refratárias à gestão racional" (SOARES, 2007, p. 85).

5.3 Governo Lula: abandono da agenda de reformas radicais e tentativa de articular uma política nacional de segurança pública

O objetivo desta seção é analisar as mudanças implementadas na área da segurança pública, nos dois governos Luiz Inácio Lula da Silva, desde seu início até o presente momento (2003 a 2006 e 2007 a 2009 ${ }^{98}$ ), analisando especialmente o modo como a política desenvolvida tem provocado deslocamentos na dinâmica federativa nesse campo.

De forma geral, o debate federativo tem considerável centralidade na agenda governamental do presidente Lula. Algumas ações institucionais expressam essa preocupação, como por exemplo, a instituição do Comitê de Articulação Federativa $(\mathrm{CAF})^{99}$, cujo trabalho com os municípios na área da segurança pública já foi referido

\footnotetext{
${ }^{97}$ Estudo de Grossi de Souza (2004), analisando os convênios firmados com estados e municípios, desde a criação do Fundo até 0 ano de 2003, também mostra que os recursos do FNSP foram destinados quase que exclusivamente para a aquisição de armas, coletes, veículos e munição.

${ }^{98} \mathrm{O}$ segundo mandato se encerra em dezembro de 2010.

99 O CAF foi instituído inicialmente por um protocolo de cooperação federativa, firmado em 2003 , ganhando, posteriormente, maior institucionalidade por meio do Decreto n. 6.181, de 3 de agosto de 2007. O CAF foi instituído no âmbito da Secretaria de Relações Institucionais da Presidência da República, "com a finalidade de promover a articulação na formulação de estratégias e implementação de ações coordenadas e cooperativas entre as esferas federal e municipal de governo, para atendimento das demandas da sociedade e aprimoramento das relações federativas" (Artigo 1ํㅡㄹ do aludido Decreto).
} 
na seção 5.1 .2 deste capítulo, e a aprovação da Lei do Consórcio Público ${ }^{100}$, que se apresenta como importante instrumento institucional para a ampliação da arena de negociação e de cooperação intergovernamental na execução de várias políticas públicas, como a dos recursos hídricos, transporte e segurança pública, a partir de uma perspectiva de desenvolvimento regional. Segundo informações da assessoria jurídica do Ministério da Justiça, o primeiro e, até o momento, único consórcio público criado exclusivamente para trabalhar com segurança pública no país é o Consórcio de Segurança Pública e Cidadania de Londrina e Região Metropolitana (CISMEL), oficializado em outubro de $2009^{101}$. Dotado de personalidade jurídica, o Consórcio de Londrina e região, em 5 de novembro de 2009, firmou com o Ministério da Justiça um convênio de cooperação federativa para sua adesão ao Pronasci.

No campo da segurança pública especificamente, o primeiro mandato do presidente Lula, eleito com um Programa de Governo propositor de mudanças estruturais para a área, substituiu a agenda reformista radical por uma agenda incremental fortemente marcada pelo tom de uma rearticulação federativa na matéria. No primeiro mandato, foi instituído o Sistema Único de Segurança Pública (SUSP), que, apesar de se pautar pelo tema do rearranjo federativo, tem se limitado, até o momento, a um rearranjo administrativo-operacional visando a uma maior articulação entre as polícias estaduais. Ainda no primeiro governo, foram realizadas alterações nas regras do Fundo Nacional de Segurança Pública e foi instituída a Força Nacional de Segurança Pública objetivando, segundo se explicita em seus instrumentos constitutivos, a cooperação intergovernamental em ações específicas.

No segundo governo, foi lançado o Programa Nacional de Segurança Pública com Cidadania, que prevê maior cooperação intergovernamental no enfrentamento da violência, por meio de ações voltadas a qualificar a repressão e a fortalecer a

\footnotetext{
${ }^{100} \mathrm{O}$ consórcio público foi instituído pela Lei Federal 11.107, regulamentada pelo Decreto 6.017, de 17 de janeiro de 2007.

${ }^{101}$ No caso da segurança pública, o fenômeno da migração do crime e a concentração da violência, particularmente em regiões urbanas conurbadas, demandam uma ação coletiva e coordenada. Existem várias experiências pontuais de gestão intermunicipal da segurança. No estado de São Paulo, por exemplo, pode-se citar o Consórcio Intermunicipal do Grande ABC (que reúne sete municípios da região e que tem entre seus grupos de trabalho um Núcleo Estratégico de Segurança Pública) e a Câmara Setorial de Segurança Pública dos municípios da região oeste da Grande São Paulo. Estes consórcios, contudo, ainda não se valem da nova institucionalidade inaugurada pela Lei de Consórcios Públicos. Nos dois exemplos mencionados, o que existe, até o momento, é um pacto político-administrativo que não gera personalidade jurídica e não oferece garantias jurídicas. Essa constitui exatamente a inovação introduzida pela Lei de Consórcios Públicos: potencializar a capacidade técnica, gerencial e financeira dos entes federados, por meio da cooperação horizontal ou vertical entre eles, de forma juridicamente mais estável e segura.
} 
prevenção. A primeira Conferência Nacional de Segurança Pública, que se realizou no final do segundo mandato, inaugurou uma ampla discussão sobre o tema, com a finalidade de construir princípios e diretrizes orientadoras de uma política nacional de segurança.

5.3.1 Promessas do Plano de Segurança Pública e recuo na proposição das reformas radicais

O primeiro governo de Lula (2003 a 2006) assumiu como plano de governo na área da segurança pública o Projeto Segurança Pública para o Brasil (2002), cuja redação foi discutida por vários especialistas e representantes da sociedade civil, durante a campanha para as eleições presidenciais ${ }^{102}$. $O$ projeto propunha alterações substanciais nas características do modelo tradicional da política de segurança, com reformas estruturais a serem promovidas em vários níveis do sistema, em especial nas instituições policiais.

Para uma mudança substantiva do modelo de polícia, o Projeto Segurança Pública para o Brasil (2002) previa que, com a implementação do Sistema Único de Segurança Pública, dever-se-ia instituir, progressivamente, um novo modelo de segurança pública, com as seguintes características: a) fim do controle militar sobre as polícias militares, que deixariam de ser consideradas forças auxiliares e de reserva do Exército, subordinando-se exclusivamente aos governadores de estados; b) lei orgânica única para as polícias estaduais; c) investigação preliminar sem indiciamento (extinção do inquérito policial); d) desconstitucionalização do artigo 144 da Constituição Federal, de forma a que cada estado da federação tivesse liberdade institucional e legal para adotar diferentes arranjos para suas polícias, observado, em qualquer caso, o ciclo completo da atividade policial. Reforçando o princípio federativo, cada estado, da forma que lhe fosse mais adequada, organizaria suas instituições policiais, criando uma ou várias polícias de ciclo completo. Além disso, deveriam ser seriam previstos dispositivos constitucionais garantidores de uma

\footnotetext{
102 O Projeto Segurança Pública para o Brasil foi elaborado pelo Instituto Cidadania e coordenado por Antonio Carlos Biscaia, Benedito Mariano, Luiz Eduardo Soares e Roberto Aguiar.
} 
unidade orgânico-funcional mínima entre todos os arranjos organizacionais a serem adotados no país.

As mencionadas propostas de mudanças estruturais, no entanto, não se transformaram sequer em projeto de emenda constitucional, a ser encaminhado pelo executivo federal ao Congresso Nacional. As preferências reformistas radicais, expressas no Projeto Segurança Pública para o Brasil, não chegaram a entrar, de fato, para a agenda decisional do governo. Houve um recuo em relação a elas.

Para Luiz Eduardo Soares, um dos coordenadores do Projeto Segurança Pública para o Brasil e primeiro Secretário Nacional de Segurança Pública do Governo Lula ${ }^{103}$, caso a União assumisse o protagonismo da maior reforma institucional das polícias no país, o governo federal ficaria exposto a riscos políticos, na medida em que Ihe seria imputada a responsabilidade por problemas ocorridos em cada cidade. "O desgaste seria inevitável, uma vez que os efeitos práticos de uma reorganização institucional só se fariam sentir a longo prazo" (SOARES, 2007, p. 88).

No caso em análise, além do alto custo de reversão que a mudança do modelo das instituições policiais poderia impor (path dependence), haveria também, segundo Soares, um risco político, isto é, o risco de um alto custo eleitoral decorrente do fato de que se poderia imputar ao governo federal, qualquer situação de violência ocorrida nas cidades, logo após as mudanças estruturais, já que seus benefícios não seriam sentidos de imediato.

Pierson (1996) utiliza o conceito de blame avoidance para definir a estratégia de evitar os custos políticos das reformas que impliquem em imposição de perdas. Nesses casos, a estratégia dominante dos governos é dividir com a oposição os custos políticos da reforma, por meio da construção de alianças e de uma ampla coalizão capaz de dar sustentação à mudança pretendida. No caso da reforma estrutural do modelo de segurança pública brasileiro, contudo, a constituição da referida coalizão ainda apresenta vários desafios a serem superados, como já visto no capítulo 4.

Segundo afirmou o Ministro Tarso Genro em discurso proferido no dia 8 de dezembro de 2008, no ato de lançamento da primeira Conferência Nacional de Segurança Pública, em Brasília, o recuo quanto às reformas estruturais ocorreu

${ }^{103}$ Luiz Eduardo Soares ocupou o cargo de Secretário Nacional de Segurança Pública por pouco menos de um ano, tendo sido substituído pelo delegado da Polícia Federal, Luiz Fernando Correa. 
exatamente em razão de não existir ainda uma coalizão majoritária em torno das mudanças ${ }^{104}$. Conforme o que foi analisado no capítulo 4 , não há, de fato, consenso entre os atores da comunidade da política de segurança pública sobre as propostas reformistas apresentadas no Projeto Segurança Pública para o Brasil, especialmente no que diz respeito à proposta de desconstitucionalização do artigo 144 da Constituição Federal e do ciclo completo da atividade policial.

Face aos altos custos que seriam impostos por uma eventual reforma radical no modelo da política e face à inexistência de uma coalizão reformista, as mudanças radicais não foram levadas adiante, conformando-se novas preferências estratégicas. Além disso, a exemplo do que ocorreu no Governo FHC, outros constrangimentos e disputas de agenda parecem ter operado no Governo Lula, tendo em vista que não apenas as reformas radicais, mas também algumas reformas incrementais previstas no seu programa de segurança pública também não foram, até o momento, implementadas, como é o caso do estabelecimento de vencimento básico nacional para as polícias e da criação da Ouvidoria da Polícia Federal.

\subsubsection{Sistema Único de Segurança Pública - SUSP}

Segundo o Programa Segurança Pública para o Brasil (2002), o SUSP foi idealizado para promover uma progressiva integração entre as polícias militares e civis, com o compartilhamento de rotinas, procedimentos e estruturas, considerada a histórica dualidade do setor e a dificuldade dessas corporações atuarem conjuntamente. Integrando-se as duas polícias, as futuras reformas estruturais que deveriam ocorrer em médio e longo prazos não causariam tantos traumas. Para atingir o objetivo proposto, o SUSP centrava-se, entre outros, nos seguintes elementos no que diz respeito às polícias civis e militares: a) unificação progressiva das academias e escolas de formação; b) integração territorial necessária à integração da atuação operacional das polícias; c) instituição de comissões civis

\footnotetext{
${ }^{104} \mathrm{Na}$ ocasião, o Ministro Tarso Genro afirmou, ainda, que a ampliação do debate sobre a segurança pública envolvendo os atores políticos e sociais que incidem na política é um dos objetivos principais da primeira Conferência Nacional de Segurança Pública.
} 
comunitárias de segurança, objetivando aproximar as instituições policiais da comunidade; d) criação de órgão integrado de informação e inteligência policial; e) corregedoria única; f) obediência aos dispositivos regulamentadores que proíbem a participação de policiais nas empresas de segurança privada; g) grupo unificado de mediação de conflitos; h) ouvidorias de polícia autônomas e independentes; i) policiamento comunitário; j) mudanças nos regulamentos disciplinares e leis orgânicas policiais; k) controle rigoroso do uso da força letal; l) autonomia dos órgãos periciais. Ao implementar as ações previstas, o SUSP, ainda segundo o Projeto Segurança Pública para o Brasil (2002), deveria criar as condições necessárias para a instituição de um novo modelo de política, que culminaria, como já foi mencionado, com o fim do controle do Exército sobre as polícias, o fim do inquérito policial e a desconstitucionalização do artigo 144 da Constituição Federal.

Instituído sem uma normativa legal ${ }^{105}$ e sob a gestão da SENASP, o SUSP está estruturado em seis eixos estratégicos, com suas respectivas ações: a) gestão unificada da informação - implantação nacional do Sistema Nacional de Estatísticas de Segurança Pública e Justiça Criminal (SINESPJC); b) gestão do sistema de segurança pública - reorganização institucional, integrando as organizações policiais civis e militares no nível estratégico e de formação; c) formação e aperfeiçoamento dos policiais - implantação nacional da matriz curricular mínima, implantação de rede de ensino à distância $(E A D)$ e da Rede de Altos Estudos em Segurança Pública (RENAESP); d) valorização das perícias - implantação do Sistema Nacional de Identificação Criminal (AFIS) e implantação dos Laboratórios regionais de DNA; e) ações de prevenção da violência - implantação de consórcios metropolitanos de prevenção da criminalidade e assinatura de convênios com municípios na área de prevenção; e f) criação de corregedorias unificadas e de ouvidorias independentes.

A implantação do SUSP centrou-se nos estados, que deveriam estabelecer interfaces com a polícia federal e com as guardas municipais. Foram assinados, entre cada um dos estados e a União, convênios de cooperação federativa visando à adesão ao SUSP. Os termos do referido convênio eram bastante genéricos, tanto que foram firmados com todos os governadores dos estados, sem exceção, demonstrando a adesão a um consenso mínimo referido, principalmente, à necessidade de maior integração no trabalho policial.

105 Projeto de Lei $3.461 / 2008$, visando à legalização do SUSP, encontra-se em tramitação no Congresso Nacional. 
O convênio de cooperação exigia que o estado, ao aderir ao SUSP, instituísse um Gabinete de Gestão Integrada Estadual (GGI-E), que é um fórum deliberativo e executivo, sem hierarquia, e que, respeitando a autonomia das instituições que o compõem, deve operar por consenso. O objetivo do GGl é coordenar a implementação das ações do SUSP no estado, visando à integração entre os órgãos do sistema de justiça criminal, a implantação do planejamento estratégico como ferramenta gerencial das ações empreendidas pelo sistema de justiça criminal e a constituição da informação como principal ferramenta de ação policial.

O dispositivo utilizado pelo governo federal para induzir os estados a aderirem ao SUSP foi o de estabelecer a referida adesão e a implantação do GGI-E como condição necessária para a obtenção de recursos do Fundo Nacional de Segurança Pública. Estados mais ricos, como São Paulo, por exemplo, que dependem muito pouco das transferências do governo federal para executar sua política de segurança pública, demoraram mais a firmar o instrumento de adesão ao SUSP.

Segundo Durante (2008), o SUSP foi criado visando a incrementar a cooperação intergovernamental e interinstitucional no âmbito do sistema policial brasileiro, sendo orientado pelos princípios do federalismo e pelo respeito à autonomia dos estados e dos municípios. Na prática, porém, sua finalidade central tem sido a de promover o incremento de ações operacionais no âmbito das polícias estaduais, por meio dos GGI-Es, e a de promover ações de aprimoramento na formação e capacitação dos profissionais da segurança pública.

Apesar desse incremento operacional ser considerado importante para a diminuição dos conflitos entre as polícias e para conferir maior eficiência ao trabalho policial, os próprios secretários executivos dos GGI-Es apontaram, durante a realização do Fórum Internacional de Gabinetes de Gestão Integrada, realizado em novembro 2007, em São Luiz do Maranhão, que a atuação reativa dos GGl-Es, restrita na prática a um foco operacional, constitui ainda um ponto fraco a ser superado. (MINISTÉRIO DA JUSTIÇA, 2008b).

O eixo formativo do SUSP é considerado um dos mais desenvolvidos dos seis eixos que o estruturam. Até 2003, segundo diagnóstico realizado pela SENASP, as academias e os centros de formação para policiais nos estados apresentavam os seguintes problemas: ausência de padronização dos conteúdos formativos; princípios pedagógicos frágeis; ações educativas excludentes; quadro docente 
insuficiente; instrutores pouco qualificados e precariedade e subutilização das estruturas de ensino. Além disso, os dados indicavam baixa escolaridade do profissional de segurança pública no país. Em 2001, aproximadamente 34\% dos policiais militares e $14 \%$ dos policiais civis do país tinham apenas o ensino fundamental. No mesmo ano, somente $8,6 \%$ dos policiais militares e $20,2 \%$ dos policiais civis possuíam nível universitário (MUNIZ; ZACCHI, 2005).

Para reverter esse quadro, várias medidas foram adotadas desde o primeiro mandato do presidente Lula. Estabeleceu-se uma matriz curricular básica nacional como referencial teórico-metodológico para orientar as atividades formativas de todos os profissionais da área de segurança pública. Instituiu-se a Rede Nacional de Altos Estudos em Segurança Pública (RENAESP), que fomenta a formação dos profissionais de segurança por meio de cursos de graduação e especialização desenvolvidos por 65 universidades cadastradas na Rede, que oferecem 81 cursos de especialização, com duração média de 360 horas/aula. Mais de cinco mil profissionais de segurança e agentes comunitários de segurança pública já participaram dos cursos de pós-graduação oferecidos na modalidade presencial ou à distância. A RENAESP trabalha, também, com cursos de curta duração à distância (EAD). Para possibilitar os cursos pela internet, até 2008, já haviam sido instalados, com recursos do governo federal, 270 telecentros nas 27 unidades da federação, com a realização de 14 ciclos formativos envolvendo 30 cursos diferentes. Só no ano de 2008, 369 mil profissionais participaram de cursos à distância oferecidos pela RENAESP.

O SUSP não implicou reformas estruturais no modelo de polícia dual e de ciclo incompleto que marcam o sistema policial brasileiro, nem propiciou a integração com os municípios que, de forma geral, não são chamados a participar dos gabinetes de gestão integrada estaduais. Além disso, mudanças previstas inicialmente como importantes para a integração das polícias e que não dependiam de alteração constitucional também não foram implementadas (ou se deram apenas pontualmente, em um ou outro estado) como, por exemplo, a criação de corregedoria única e de escolas de formação unificadas, reforma nos regulamentos disciplinares e nas leis orgânicas policiais e grupo unificado de mediação de conflitos. Não obstante, o SUSP representa uma mudança incremental que contribui, em maior ou menor medida, para melhorar a integração operacional entre as polícias 
e para fomentar e propiciar melhor formação e capacitação profissional aos trabalhadores da segurança pública.

5.3.3 Fundo Nacional de Segurança Pública: alteração legislativa e novos critérios para a distribuição de recursos

Até o ano de 2003, o Fundo Nacional de Segurança Pública, instituído no segundo Governo FHC, destinava recursos apenas para os estados e para os municípios que tivessem guardas municipais. Reconhecendo cada vez mais a vocação dos municípios para a formulação e o desenvolvimento de políticas preventivas da violência, o Governo Lula propôs, em 2003, uma alteração importante na legislação do Fundo, de forma a permitir a destinação de verbas também para municípios que não possuam Guarda, para a "elaboração de projetos multissetoriais de prevenção da violência e da criminalidade, especialmente voltados para jovens em situação de vulnerabilidade"106.

Os projetos apresentados ao FNSP são analisados por um conselho gestor, composto por dois representantes do Ministério da Justiça; um representante do Ministério do Planejamento, Orçamento e Gestão; um representante da Casa Civil da Presidência da República; um representante do Gabinete de Segurança Institucional da Presidência da República e um representante da Procuradoria-Geral da República. Apenas o nível federal, como se vê, tem assento no Conselho Gestor do Fundo, não havendo representação institucionalizada dos estados e municípios.

Com a alteração dada pela Lei no. 10.746/03, o FNSP passou a ter por objetivo precípuo apoiar projetos na área de segurança pública e de prevenção da violência por meio da transferência de recursos para as unidades subnacionais. $O$ governo federal, no entanto, não é o grande financiador da política de segurança pública para os estados. Como mostra a tabela abaixo, o governo federal é

\footnotetext{
106 Página institucional do Fundo Nacional de Segurança Pública/ SENASP, disponível em: $<$ http://www.mj.gov.br/Senasp/SUSP/FNSP/fnsp_municipios.htm>.
} 
responsável por pouco mais de $1 \%$ do gasto total dos estados em segurança pública $^{107}$.

\section{Razão entre os recursos gastos pelos estados e recursos repassados} pela SENASP - 2003 a 2006

\begin{tabular}{|c|c|c|c|c|c|}
\hline \multirow{3}{*}{$\begin{array}{l}\text { Unidades da } \\
\text { Federação }\end{array}$} & \multicolumn{5}{|c|}{ Recursos Gastos pelos Estados e Repassados pela SENASP } \\
\hline & \multicolumn{2}{|c|}{ Gastos Estaduais } & \multicolumn{2}{|c|}{ Repassados FNSP } & \multirow{2}{*}{$\begin{array}{c}\text { Razão } \\
\text { Estado / } \\
\text { FNSP }\end{array}$} \\
\hline & $\mathbf{R} \$$ & (\%) & $\mathbf{R} \$$ & (\%) & \\
\hline Acre & $\mathrm{R} \$ 531.065 .129,05$ & 0,6 & $\mathrm{R} \$ 17.554 .667,67$ & 2,1 & 30,25 \\
\hline Alagoas & $\mathrm{R} \$ 1.119 .348 .210,77$ & 1,4 & $\mathrm{R} \$ 14.786 .845,90$ & 1,7 & 75,70 \\
\hline Amazonas & $\mathrm{R} \$ 1.522 .645 .028,76$ & 1,8 & $\mathrm{R} \$ 22.445 .093,65$ & 2,6 & 67,84 \\
\hline Amapá & $\mathrm{R} \$ 1.512 .380 .844,57$ & 1,8 & $\mathrm{R} \$ 21.510 .617,31$ & 2,5 & 70,31 \\
\hline Bahia & $\mathrm{R} \$ 4.565 .155 .088,33$ & 5,5 & $\mathrm{R} \$ 35.660 .942,12$ & 4,2 & 128,02 \\
\hline Ceará & $\mathrm{R} \$ 1.416 .976 .805,42$ & 1,7 & $\mathrm{R} \$ 22.813 .710,23$ & 2,7 & 62,11 \\
\hline Distrito & $\mathrm{R} \$ 548.564 .145,69$ & 0,7 & $\mathrm{R} \$ 18.782 .298,27$ & 2,2 & 29,21 \\
\hline Espírito & $\mathrm{R} \$ 1.847 .480$. & 2,2 & $\mathrm{R} \$ 34.123$. & 4,0 & 54,14 \\
\hline Goiás & $\mathrm{R} \$ 2.437 .982 .043,40$ & 2,9 & $\mathrm{R} \$ 29.659 .631,67$ & 3,5 & 82,20 \\
\hline Maranhão & $\mathrm{R} \$ 448.715 .385,43$ & 0,5 & $\mathrm{R} \$ 17.766 .668,00$ & 2,1 & 25,26 \\
\hline \multicolumn{6}{|l|}{ Mato Grosso } \\
\hline Mato Grosso do Sul & $\mathrm{R} \$ 2.811 .561 .119,40$ & 3,4 & $\mathrm{R} \$ 21.084 .894,86$ & 2,5 & 133,34 \\
\hline Minas Gerais & $\mathrm{R} \$ 12.347 .873 .697,82$ & 14,9 & $\mathrm{R} \$ 65.618 .836,26$ & 7,7 & 188,18 \\
\hline Pará & $\mathrm{R} \$ 1.830 .572 .872,59$ & 2,2 & $\mathrm{R} \$ 30.738 .451,75$ & 3,6 & 59,55 \\
\hline \multicolumn{6}{|l|}{ Paraíba } \\
\hline Paraná & $\mathrm{R} \$ 3.603 .213 .010,76$ & 4,4 & $\mathrm{R} \$ 28.144 .085,72$ & 3,3 & 128,03 \\
\hline Pernambuco & $\mathrm{R} \$ 2.853 .881 .604,86$ & 3,5 & $\mathrm{R} \$ 40.761 .708,02$ & 4,8 & 70,01 \\
\hline Piauí & $\mathrm{R} \$ 816.468 .859,14$ & 1,0 & $\mathrm{R} \$ 19.836 .744,09$ & 2,3 & 41,16 \\
\hline Rio de Janeiro & $\mathrm{R} \$ 9.753 .533 .242,97$ & 11,8 & $\mathrm{R} \$ 88.990 .553,44$ & 10,4 & 109,60 \\
\hline Rio Grande do Norte & $\mathrm{R} \$ 1.085 .914 .061,04$ & 1,3 & $\mathrm{R} \$ 31.453 .659,20$ & 3,7 & 34,52 \\
\hline Rio Grande do Sul & $\mathrm{R} \$ 4.849 .262 .182,31$ & 5,9 & $\mathrm{R} \$ 60.036 .625,52$ & 7,0 & 80,77 \\
\hline Rondônia & $\mathrm{R} \$ 1.143 .218 .736,50$ & 1,4 & $\mathrm{R} \$ 16.092 .047,04$ & 1,9 & 71,04 \\
\hline Roraima & $\mathrm{R} \$ 242.956 .384,86$ & 0,3 & $\mathrm{R} \$ 19.975 .205,35$ & 2,3 & 12,16 \\
\hline Santa Catarina & $\mathrm{R} \$ 3.387 .765 .573,49$ & 4,1 & $\mathrm{R} \$ 19.890 .809,35$ & 2,3 & 170,32 \\
\hline São Paulo & $\mathrm{R} \$ 20.559 .835 .861,44$ & 24,9 & $\mathrm{R} \$ 148.908 .707,92$ & 17,5 & 138,07 \\
\hline Sergipe & $\mathrm{R} \$ 867.551 .424,53$ & 1,0 & $\mathrm{R} \$ 12.995 .174,77$ & 1,5 & 66,76 \\
\hline Tocantins & $\mathrm{R} \$ 612.953 .945,62$ & 0,7 & $\mathrm{R} \$ 13.600 .147,20$ & 1,6 & 45,07 \\
\hline Total & R\$ 82.716.875.868,19 & 100,0 & $\mathrm{R} \$ 853.231 .483,46$ & 100,0 & 96,95 \\
\hline
\end{tabular}

Fonte: TCU e SENASP/MJ.

Com relação aos critérios para a transferência de recursos para os municípios, para que possam se beneficiar dos recursos do Fundo, eles devem

\footnotetext{
${ }^{107}$ No ano de 2006, por exemplo, o Fundo Nacional de Segurança Pública destinou R $\$ 170$ milhões para investimentos em todo o país, enquanto apenas no estado de São Paulo o orçamento da segurança pública foi de seis bilhões de reais (RAMOS, 2007).
} 
desenvolver suas atividades de forma integrada aos órgãos estaduais de segurança pública e não podem estar inadimplentes com a SENASP. Levam-se também em conta as taxas de criminalidade, o tamanho do público a ser beneficiado pelas políticas e ações de segurança pública, o tamanho do município, a concentração da população em área urbana, as condições socioeconômicas da população e a capacidade do município de investir na área de segurança pública, por sua própria conta.

No caso da distribuição de recursos do Fundo para os estados, além dos critérios acima mencionados, é realizada uma avaliação dos avanços do estado na implementação do SUSP em todos os seus eixos, induzindo, assim, em tese, a adoção das diretrizes da política nacional. Para recebimento de recursos do FNSP é necessário também que o estado tenha instituído um Gabinete de Gestão Integrada Estadual. ${ }^{108}$ Segundo Durante ${ }^{109}$, os critérios de distribuição dos recursos do FNSP foram estabelecidos com a preocupação de se reduzir as assimetrias regionais, por isso o Produto Interno Bruto (PIB) e o Índice de Desenvolvimento Humano (IDH) do estado a ser beneficiado são também elementos importantes na análise que precede a transferência de recursos.

De 2003 a 2006, os recursos dirigidos à SENASP por meio do FNSP foram diminuindo significativamente, numa relação inversamente proporcional ao orçamento total da segurança pública, conforme se verifica na tabela abaixo. Isso parece ter ligação direta com o marcante fortalecimento da polícia federal no governo Lula ${ }^{110}$, uma vez que os investimentos nessa polícia aumentaram significativamente no mesmo período (DURANTE, 2008). ${ }^{111}$

\footnotetext{
${ }^{108}$ Segundo informações dadas por gestores da SENASP, os estados respondem periodicamente a questionários sobre o cumprimento dessas condicionalidades, porém, o ideal seria um monitoramento em que se realizassem também visitas in loco para se verificar a veracidade das informações prestadas e a qualidade das ações desenvolvidas pelas unidades subnacionais.

${ }_{109}$ Entrevista concedida à autora desta dissertação, em 31 de outubro, em Brasília.

110 Após a saída de Luiz Eduardo Soares da SENASP, ainda no primeiro ano do Governo Lula, a decisão do governo federal parece ter sido a de fortalecer sua própria polícia. Durante o período de pouco mais de três anos em que o delegado da Polícia Federal, Luiz Fernando Correa, esteve à frente da SENASP (apesar de o Departamento da Polícia Federal não se vincular a esta última), o orçamento da Polícia Federal aumentou significativamente, enquanto o montante de recursos do FNSP, repassados às unidades subnacionais, sofreu sensível redução em relação aos investimentos feitos no Governo FHC. Após deixar o cargo de Secretário Nacional de Segurança Pública, no final de 2007, Luiz Fernando Correa foi nomeado diretor do Departamento de Polícia Federal. Exemplo da força política que a Polícia Federal ganhou nos últimos anos é o fato de que, dos 26 estados da Federação, no final de 2009, em 17 deles os secretários estaduais de segurança pública eram oriundos da Polícia Federal, segundo informado pela SENASP. Até então, era significativamente mais
} 
Percentual de Recursos do FNSP Liquidados no Conjunto do Orçamento de Segurança Pública Executado do Governo Federal (Brasil - 2000/2006)

\begin{tabular}{|c|r|r|c|}
\hline Ano & Orçamento Total & FNSP Liquidado & $\begin{array}{c}\text { Percentual FNSP / } \\
\text { Orçamento Total }\end{array}$ \\
\hline 2000 & $\mathrm{R} \$ 1.735 .478 .742$ & $\mathrm{R} \$ 251.622 .251$ & 14,50 \\
\hline 2001 & $\mathrm{R} \$ 2.039 .459 .935$ & $\mathrm{R} \$ 402.626 .548$ & 19,74 \\
\hline 2002 & $\mathrm{R} \$ 1.650 .368 .268$ & $\mathrm{R} \$ 328.860 .014$ & 19,93 \\
\hline 2003 & $\mathrm{R} \$ 2.196 .130 .391$ & $\mathrm{R} \$ 304.854 .007$ & 13,88 \\
\hline 2004 & $\mathrm{R} \$ 2.522 .992 .649$ & $\mathrm{R} \$ 283.870 .271$ & 11,25 \\
\hline 2005 & $\mathrm{R} \$ 2.704 .613 .948$ & $\mathrm{R} \$ 242.958 .508$ & 8,98 \\
\hline $2006^{(1)}$ & $\mathrm{R} \$ 3.477 .873 .865$ & $\mathrm{R} \$ 199.711 .631$ & 5,74 \\
\hline
\end{tabular}

Fonte: TCU

(1) Não inlcui recursos aplicados nos Jogos Pan-Americanos

A partir de 2003, o governo federal passou a realizar também aquisições diretas, especialmente de equipamentos e viaturas, que são, posteriormente, doados aos estados e municípios mediante o compromisso de serem utilizados de acordo com as diretrizes do SUSP. Dessa forma, a Secretaria Nacional de Segurança Pública tem dado corpo à sua política de segurança pública, induzindo a gestão de políticas e processos e a padronização de procedimentos, técnicas e equipamentos.

No período de 2003 a 2007, os gastos com aquisição direta, com recursos do FNSP, aumentaram (com ligeiro declínio em 2007), em detrimento dos recursos repassados às unidades subnacionais, conforme se depreende do gráfico a seguir:

frequente a presença de secretários de segurança pública estaduais com formação militar, juristas ou integrantes do Ministério Público.

111 Do ponto de vista dos atores do poder executivo federal, notam-se ênfases diferenciadas nas diferentes gestões do Ministério da Justiça. Até o momento, foram dois os Ministros da Justiça na era Lula. Enquanto Márcio Thomaz Bastos priorizou investimentos na Polícia Federal, Tarso Genro deu início a um processo gradual de aumento dos investimentos para o FNSP (retomando a tendência do Governo $\mathrm{FHC}$ ) e lançou o Pronasci, aumentando o volume de recursos destinados à articulação de ações repressivas e preventivas, com envolvimento dos três níveis de governo. 


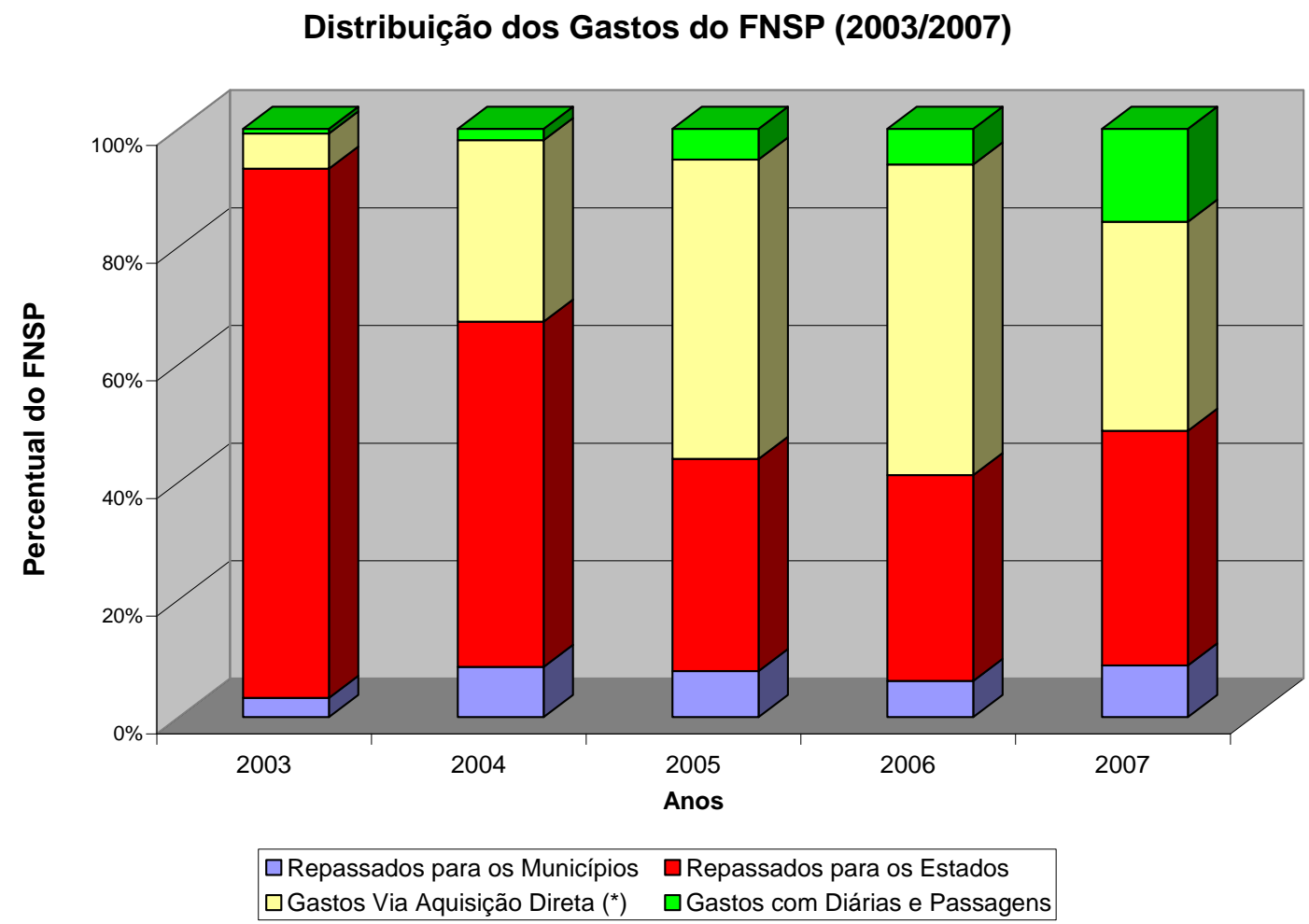

Fonte: Relatório de Atividades - Implantação do SUSP, SENASP - 2007

O gráfico abaixo apresenta a natureza dos gastos com aquisições diretas em 2007, demonstrando uma preocupação com vários eixos do SUSP, como a gestão da informação e a formação dos profissionais da segurança, e não apenas com aquisição de veículos e equipamento ${ }^{112}$.

\footnotetext{
112 Segundo Muniz e Zacchi (2005, p. 17), o gasto com a aquisição de equipamentos, armamentos e viaturas constitui resposta reativa às demandas populares por mais policiamento. "Diante da falta de políticas públicas articuladas e continuadas e da real carência das polícias", esse tipo de procedimento de rotina costuma "ganhar o status de política pública na área da segurança" e "mesmo sendo um tipo de resposta reativa e pontual, ela possui visibilidade, podendo ser apresentada como um passo importante para a modernização das polícias".
} 
Total de Recursos Repassados Via Aquisição Direta (2007)

\begin{tabular}{|l|r|}
\hline \multicolumn{1}{|c|}{ Ações de Execução Direta } & \multicolumn{1}{c|}{ Valor (R\$) } \\
\hline Transferência para Organismo Internacional - PNUD & $\mathrm{R} \$ 54.160 .100,00$ \\
\hline Aquisição - Reaparelhamento & $\mathrm{R} \$ 46.702 .421,49$ \\
\hline Ampliação do Ensino à Distância / RENAESP & $\mathrm{R} \$ 24.046 .868,19$ \\
\hline Aquisição de Viaturas (Estados e municípios) & $\mathrm{R} \$ 23.404 .500,00$ \\
\hline INFOSEG & $\mathrm{R} \$ 12.216 .082,83$ \\
\hline Estruturação da Perícia (Laboratórios de DNA e Fonética Forense) & $\mathrm{R} \$ 5.024 .449,74$ \\
\hline Pagamento de Horas Aula & $\mathrm{R} \$ 4.259 .161,20$ \\
\hline Repasse de Recurso para SENAD & $\mathrm{R} \$ 1.000 .000,00$ \\
\hline Material de Consumo, permanente e serviços / Rio de Janeiro & $\mathrm{R} \$ 80.833,46$ \\
\hline Manutenção de Veículos - Força Nacional & $\mathrm{R} \$ 40.774,40$ \\
\hline Repasse de Recurso para SEPOM/PR & $\mathrm{R} \$ 15.000,00$ \\
\hline Empenhos a serem cancelados & $\mathrm{R} \$ 8.304,32$ \\
\hline Total & $\mathbf{R} \$ \mathbf{1 7 0 . 9 5 8 . 4 9 5 , 6 3}$ \\
\hline
\end{tabular}

Fonte: Relatório de Atividades - Implantação do SUSP, SENASP - 2007.

Apesar do orçamento para a segurança pública ter aumentado muito no Governo Lula em relação ao Governo FHC, este último transferiu uma quantidade muito maior de recursos do FNSP às unidades subnacionais. Porém, no Governo $\mathrm{FHC}$, os recursos do Fundo eram basicamente destinados à aquisição de veículos e equipamentos para os estados e para os municípios que tivessem guardas municipais. O Governo Lula conseguiu induzir um pequeno aumento dos gastos com a formação de agentes públicos de segurança e destinou recursos para projetos preventivos municipais, independentemente de os municípios terem guardas municipais.

5.3.4 Força Nacional: nova força policial, sem novos policiais

A Força Nacional de Segurança Pública, instituída pelo Decreto 5.289, de 29 de novembro de 2004 e, posteriormente, pela Lei n. 11.473, de 10 de maio de 2007, é um programa de cooperação intergovernamental, ao qual os estados interessados aderem voluntariamente. A cooperação federativa em questão compreende operações conjuntas, transferências de recursos e atividades de capacitação e 
qualificação de profissionais, no âmbito da Força Nacional de Segurança Pública, implementadas sob a coordenação conjunta da União e do ente convenente.

Conforme expresso no Relatório de Atividades de Implantação do Sistema Único de Segurança Pública - 2003 a 2006, a Força Nacional

[...] constitui um instrumento para fixação de uma doutrina nacional para as polícias militares estaduais; para padronização de procedimentos e equipamentos no emprego da força legal (policiamento ostensivo, ação tática, controle de distúrbios civis) e para estabelecer interoperabilidade entre as forças policiais estaduais, permitindo ações conjuntas em substituição ao indevido emprego das Forças Armadas em policiamento civil.

Emprega-se a Força Nacional no atendimento de necessidades emergenciais dos estados, em situações em que é necessária uma interferência maior do poder público ou quando for detectada a necessidade urgente de reforço na área de segurança (como foi o caso da segurança nos Jogos Pan-Americanos, realizados no Rio de Janeiro, em 2007).

A Força Nacional de Segurança Pública é composta por policiais militares e bombeiros dos grupos de elite dos estados e do Distrito Federal que tenham recebido treinamento realizado pelo Ministério da Justiça, objetivando padronizar o comportamento de todo o efetivo. O Ministério da Justiça envia ofício para todas as polícias militares do país solicitando que selecionem, entre os voluntários para receber o treinamento, aqueles que mais se destacam. Até o final de 2006, foram formados 7.981 policiais como membros da Força Nacional de Segurança Pública, oriundos das polícias de todos os estados brasileiros ${ }^{113}$.

Após treinamento ou atuação, os policiais "nivelados" se reintegram às suas respectivas funções em seus estados, repassam os conhecimentos adquiridos aos demais membros de suas corporações e levam consigo os equipamentos que utilizaram. Segundo Robson Rubin ${ }^{114}$, assessor do então secretário nacional de Segurança Pública, Luiz Fernando Correa, à época da concepção e implantação da Força Nacional, o retorno do policial à sua corporação de origem, levando consigo formação e equipamentos, expressa um ganho para os estados também. "A Força nesse sentido é uma polícia nova, sem novos policiais". Os policiais dos estados unem-se para colaborar numa missão num estado que solicite sua presença. Trata-

\footnotetext{
${ }^{113}$ Os estados de São Paulo e Paraná foram os que mais demoraram a enviar policiais.

114 Entrevista concedida à autora desta dissertação, por Robson Rubin, no dia 31 de outubro, em Brasília.
} 
se, segundo Rubin, de um grande esforço de cooperação intergovernamental em que todos os estados ganham porque têm seu corpo policial requalificado.

Até o final de 2008, a Força Nacional já havia atuado no Espírito Santo, Rio de Janeiro, Mato Grosso do Sul, entorno do Distrito Federal, Maranhão, Pará, Rondônia, Alagoas e Roraima. Mas o tema suscita controvérsias. Várias são as ações de inconstitucionalidade ajuizadas contra a criação da Força Nacional ${ }^{115}$.

Para alguns atores, a Força Nacional é uma reunião de policiais estaduais, oriundos de grupamentos de choque que imprimem à Força a marca repressiva e militarizada de suas corporações de origem ${ }^{116}$. A mesma frase utilizada por Rubin, com sentido positivo, de que "A Força é uma polícia nova, sem novos policiais", é repetida por alguns de seus críticos, porém, com conotação contrária.

Iniciativa semelhante já havia sido proposta, sem êxito, no Governo FHC, por meio da PEC 514/97 que propunha a criação de uma Guarda Nacional composta por membros das duas polícias estaduais e citava, em sua exposição de motivos, argumentos semelhantes aos apresentados pelo governo Lula para justificar a instituição da Força Nacional, quais sejam, o fortalecimento da ideia de cooperação entre os entes federados e a redução do uso excepcional das Forças Armadas em conflitos internos.

\subsubsection{Programa Nacional de Segurança Pública com Cidadania - Pronasci}

Diferentemente do Programa de Governo do primeiro mandato do presidente Lula, o segundo, intitulado "Lula Presidente - Plano de Governo 2007/2010", não previa reformas radicais e baseava-se em duas diretrizes básicas: a) integração das instituições da segurança pública; b) democratização e participação da sociedade e do estado no combate ao crime e à violência.

\footnotetext{
115 Sobre o tema, ver Pereira, Gerson da Rosa. "A inconstitucionalidade da Força Nacional de Segurança Pública". Disponível em: <http://www.forumseguranca.org.br/artigos/ainonstitucionalidade-dforca-nacional-de-seguranca-publicas. Cf. também matéria publicada pela Agência Estado, intitulada "MPF do Pará pede fim da Força Nacional de Segurança", de 1/2/2009, disponível em: <HTTP://www.jusbrasil.com.br/716909/mpf-do-para-pede-fim-da-forca-nacional-deseguranca>.

${ }_{116}$ Sobre o tema, cf. matéria publicada na Folha UOL, em 24/9/2008, intitulada "OAB acusa policiais da Força Nacional de tortura no Maranhão". Disponível em: $<$ HTTP://www1.folha.uol.com.br/folha/cotidiano/ult95u448616.shtml>.
} 
A primeira diretriz abrangia tanto a integração das instituições de forma a superar a fragmentação, a ineficiência e a ineficácia do sistema, como a integração e a articulação efetiva da política nos três níveis de governo e a articulação de ações de repressão e prevenção, "com especial atenção para as ações de inteligência e de informação em todas as esferas do sistema"117.

A segunda diretriz dizia respeito à constituição de uma "nova cultura política no trato da questão da violência", consolidando-se o paradigma da segurança pública cidadã, "orientada para a prevenção e repressão eficiente do crime, em especial do crime organizado, por meio da participação solidária da sociedade e dos aparatos policiais em todos os níveis da Federação, assumindo a segurança como direito fundamental da cidadania na sociedade brasileira".

Em consonância com ambas as diretrizes, o governo federal lançou o Programa Nacional de Segurança Pública com Cidadania - Pronasci, instituído pela Lei 1530 , de 24 de outubro de $2007^{118}$. O programa objetiva, segundo seus enunciados, a consolidação de um novo paradigma da segurança pública no Brasil, ao promover, por um lado, uma nova articulação federativa, integrando na agenda da segurança pública os três entes federados e, por outro, articulando políticas repressivas de segurança a políticas sociais preventivas, de forma a atuar também nas raízes socioculturais da violência.

O Pronasci prevê 94 ações, que incluem projetos de modernização das polícias, valorização profissional, reestruturação do sistema prisional, ações de combate à corrupção policial e ao crime organizado e ações territoriais locais de prevenção. A Lei n. 11.530, de 24 de outubro de 2007, que alterou a lei de instituição do Pronasci, estabelece quatro projetos em seu artigo $8^{\circ}$, sem prejuízo de outros: Bolsa Formação, Protejo - Proteção de Jovens em Território Vulnerável, Mulheres da Paz e Reservista Cidadão, os três últimos integrando as ações territoriais locais de prevenção.

\footnotetext{
117 Sobre a gestão da informação, ressalte-se que, ainda no primeiro mandato do presidente Lula, reestruturou-se completamente o INFOSEG, que, em 2004, ganhou uma arquitetura de rede. No orçamento de 2007, primeiro ano do segundo mandato de Lula, foram gastos $R \$ 18,9$ milhões com o Sistema Nacional de Gestão do Conhecimento e de Informações Criminais. Mais de 12 milhões foram gastos na Rede INFOSEG (que, só naquele ano, registrou mais de 20 milhões de consultas, com mais de 93 mil usuários cadastrados), segundo dados do IPEA (2008).

${ }^{118}$ O Pronasci foi inicialmente implementado nas 11 regiões metropolitanas brasileiras mais violentas, conforme identificado em pesquisa elaborada pelos Ministérios da Justiça e da Saúde: São Paulo, Belém, Belo Horizonte, Distrito Federal e entorno, Curitiba, Maceió, Porto Alegre, Recife, Rio de Janeiro, Salvador e Vitória.
} 
O Bolsa Formação complementa e fortalece a política de formação e capacitação dos profissionais de segurança pública iniciada no primeiro mandato de Lula, associando formação à valorização profissional. Trata-se de um programa de transferência direta de renda a profissionais da segurança pública que realizem cursos de formação e educação continuada habilitados pela RENAESP, desde que recebam salário inferior a $R \$ 1.700,00$ mensais e que não tenham cometido infração disciplinar grave nem tenham sofrido condenação penal nos últimos cinco anos. Com uma bolsa mensal no valor de $R \$ 400,00$, o programa atua como indutor para a adesão dos profissionais de segurança aos cursos de formação na área. Apenas no ano de 2008, cerca de 92 mil profissionais de segurança foram beneficiados (quase um sexto de todo o efetivo no país).

As ações territoriais locais são destinadas a territórios vulneráveis, indicados pelo ente federado quando de sua adesão ao Pronasci. Para esses territórios, denominados Territórios de Paz, devem ser endereçadas todas as ações locais do Pronasci, independentemente de elas serem executadas pelos estados ou pelos municípios. Trata-se de potencializar territorialmente um conjunto articulado de projetos voltados prioritariamente para jovens entre 15 e 24 anos, objetivando a redução dos índices de criminalidade. Para os territórios, devem ser endereçados, segundo o previsto no programa, não apenas projetos vinculados diretamente ao Ministério da Justiça ${ }^{119}$, mas também outros programas interministeriais financiados com recursos do Pronasci ${ }^{120}$.

Segundo a Assessoria de Assuntos Federativos do Ministério da Justiça, até setembro de 2009, os estados do Acre, Alagoas, Bahia, Ceará, Espírito Santo, Goiás, Minas Gerais, Pará, Pernambuco, Paraná, Rio de Janeiro, Rio Grande do Sul, Sergipe, São Paulo e Maranhão, além do Distrito Federal, já haviam aderido ao Pronasci de forma plena. Além desses, os estados do Piauí, Rio Grande do Norte, Tocantins, Rondônia, Mato Grosso do Sul e Mato Grosso aderiram ao Pronasci para receber pontualmente alguma de suas ações estruturantes ${ }^{121}$. Até a mencionada

\footnotetext{
${ }^{119}$ A exemplo do Protejo, do Mulheres da Paz e dos Núcleos de Justiça Comunitária.

${ }^{120}$ São exemplos de projetos interministeriais, no âmbito do Pronasci: o Programa Esporte e Lazer na Cidade e a Praça da Juventude, do Ministério do Esporte; Brasil Alfabetizado, do Ministério da Educação; Pontos de Cultura e Pontos de Memória, do Ministério da Cultura; Centros de Inclusão Digital, do Ministério da Ciência e da Tecnologia; e Projeto Farol, da SEPPIR.

${ }_{121} O$ Pronasci divide suas ações em estruturantes e territoriais locais. As ações estruturantes referem-se à modernização das instituições policiais, à reestruturação do sistema penitenciário, aos
} 
data, conforme já referido na seção 5.1.2 deste capítulo, 106 municípios integravam o Pronasci.

Para o desenvolvimento do Pronasci, o governo federal se comprometeu a investir $R \$ 6,107$ bilhões até $2012^{122}$, começando com um orçamento de $R \$ 483$ milhões em 2007, com a previsão de alocação no Orçamento Geral da União de $\mathrm{R} \$$ 1,406 bilhões por ano, conforme estruturado no Plano Plurianual 2008-2011.

No ano de 2008, a programação financeira do Pronasci sofreu contingenciamento de recursos e, ao final do ano, da dotação inicial de $R \$ 1.404$ bilhões para o programa, foram empenhados $R \$ R \$ 1,206$ bilhões e foram efetivamente liquidados pouco mais de $R \$ 700$ milhões. A tabela abaixo mostra a execução orçamentária, de acordo com as diferentes ações do programa.

núcleos de enfrentamento ao Tráfico de Pessoas, entre outras. As ações territoriais locais são as que se referem mais especificamente aos Territórios da Paz.

${ }_{122}$ A previsão inicial era de que desse montante, $R \$ 600$ milhões fossem gastos anualmente apenas com o Bolsa Formação. 


\section{Ações Orçamentárias do Pronasci - 2008}

\begin{tabular}{|c|c|c|c|}
\hline AÇÃO & AUTORIZADO & EMPENHADO & LIQUIDADO \\
\hline Bolsa-Formação & $154.197 .363,00$ & $154.197 .363,00$ & $133.717 .486,45$ \\
\hline $\begin{array}{c}\text { Implantação } \\
\text { Academia da Polícia Civil } \\
\text { do Distrito Federal }\end{array}$ & $11.540 .724,00$ & $11.540 .724,00$ & 0,00 \\
\hline $\begin{array}{l}\text { Campanha do } \\
\text { Desarmamento }\end{array}$ & $5.000 .000,00$ & $2.674 .311,54$ & $2.099 .811,54$ \\
\hline $\begin{array}{c}\text { Apoio à implementação } \\
\text { de políticas sociais }\end{array}$ & $183.329 .800,00$ & $162.231 .970,73$ & $83.100 .853,02$ \\
\hline $\begin{array}{c}\text { Gestão e Comunicação } \\
\text { do Pronasci }\end{array}$ & $37.595 .500,00$ & $24.335 .039,18$ & $10.771 .504,50$ \\
\hline $\begin{array}{c}\text { Fortalecimento das } \\
\text { instituições de Segurança } \\
\text { Pública }\end{array}$ & $318.741 .537,00$ & $309.362 .126,18$ & 298.715.774,81 \\
\hline $\begin{array}{c}\text { Modernização } \\
\text { estabelecimentos penais }\end{array}$ & $20.085 .793,00$ & $15.156 .300,00$ & 0,00 \\
\hline $\begin{array}{c}\text { Apoio à implementação } \\
\text { de políticas de segurança } \\
\text { cidadã }\end{array}$ & $218.951 .510,00$ & $168.669 .188,16$ & $121.272 .230,36$ \\
\hline $\begin{array}{l}\text { Valorização de } \\
\text { profissionais da } \\
\text { Segurança Pública }\end{array}$ & $47.045 .860,00$ & $44.747 .415,02$ & $38.919 .822,13$ \\
\hline $\begin{array}{l}\text { Apoio à construção de } \\
\text { estabelecimentos penais } \\
\text { especiais }\end{array}$ & $135.900 .000,00$ & $133.200 .000,00$ & 0,00 \\
\hline TOTAL & $1.132 .388 .087,00$ & 1.026.114.437,81 & $700.138 .206,81$ \\
\hline
\end{tabular}

Fonte: SIMAP/SIAFI. FGV Projetos (Pronasci em números, 2009).

Da destinação total dos recursos em 2008, $72 \%$ foram direcionados aos estados, $26 \%$ aos municípios e $2 \%$ à federação. O comitê gestor do Pronasci aprovou 415 projetos, dos quais 226 foram propostos pelos estados e 185 pelos municípios (SIMAP/PRONASCI, jan. 2009). 
Ao enunciar, como um de seus postulados, que à repressão qualificada deve se somar a prevenção para que se possa ter um provimento adequado de segurança, o Pronasci aponta para a necessidade de uma concertação federativa, de forma que todos os entes federados trabalhem de maneira integrada, complementar e cooperativa. Em toda federação democrática o jogo federativo depende da capacidade de coordenação intergovernamental, ou seja, da manutenção do equilíbrio entre autonomia e cooperação, de negociações, de coalizões e de induções por parte do governo federal (ABRUCIO, 2005). A manutenção do pacto federativo depende precisamente da sustentação de um equilíbrio entre a interdependência dos entes federados e sua autonomia, sendo a esfera federal cada vez mais chamada não só a manter esse equilíbrio, mas também a expandir as políticas sociais, entre elas, a de segurança ${ }^{123}$.

O Pronasci fomenta a integração dos três níveis de governo e nesse sentido reconhece o município como um novo ator protagônico da política de segurança pública no país. Segundo declaração do ministro Tarso Genro, em seminário de capacitação do Pronasci, realizado em Brasília, em fevereiro de 2008, esse programa é produto de várias articulações e conversas, e foi inspirado também na experiência de algumas cidades brasileiras que pautaram em suas agendas o tema da segurança urbana, atuando por meio da implementação de políticas preventivas da violência, de forma complementar às políticas policiais repressivas.

Como se viu na secção 5.1.2 deste capítulo, muitos municípios, frente à crescente criminalidade e à limitação constitucional para atuarem repressivamente na área de segurança pública, inovaram de maneira exitosa ${ }^{124}$, valendo-se de suas competências para a implementação de políticas sociais e urbanas e de seu poder de polícia administrativa. Nesse sentido, as unidades constituintes se configuram como atores institucionais poderosos, capazes de implementar suas próprias políticas e de influenciar o caráter das ações da autoridade central ${ }^{125}$ (PIERSON,

${ }^{123}$ Segundo o disposto no Art. $6^{\circ}$, da CF, a segurança figura entre os direitos sociais: "São direitos sociais a educação, a saúde, o trabalho, a moradia, o lazer, a segurança, a previdência social, a proteção à maternidade e à infância, a assistência aos desamparados, na forma desta Constituição". ${ }_{124}$ Para um relato de algumas dessas experiências locais em municípios como Diadema, Porto Alegre, Vitória e Recife, cf. Sento-Sé (2005).

125 Processo semelhante ocorreu com os programas de renda mínima, em que o desenho do federalismo possibilitou sua implementação, inicialmente em âmbito municipal, passando, em seguida, para o âmbito estadual - tendo em vista o sucesso dessas experiências e o alto impacto eleitoral desse tipo de programa - até se tornarem programa federal, no Governo Lula, via Bolsa Família. 
1995, p. 458). Experiências inovadoras de vários municípios brasileiros influenciaram a política nacional, indicando que a competição entre as várias unidades federativas é, nesse sentido, uma vantagem dos sistemas federais, na medida em que estimula a governança efetiva ${ }^{126}$.

Segundo Pierson (1995, p.456), inovações bem sucedidas podem facilitar um processo de difusão através da federação ou conferir uma racionalidade para que a autoridade central universalize a nova política. O Pronasci tem o mérito de, pela primeira vez, colocar essa inovação na agenda nacional, refletindo experiências municipais exitosas que estão ocorrendo no país.

Quando estados e municípios firmam um convênio de cooperação federativa aderindo ao Pronasci, assumem a responsabilidade, entre outras, de instituírem o Gabinete de Gestão Integrada $(G G I)^{127}$. Considerando que os estados já instituíram seus GGI-Es em razão do SUSP, a inovação do Pronasci aqui diz respeito à obrigação de os municípios instituírem o Gabinete de Gestão Integrada Municipal (GGI-M), em que devem se articular os três níveis de governo, visando à gestão das ações do programa em âmbito local.

Dos 84 municípios que haviam aderido ao Pronasci até o final de 2008, 73 já haviam produzido instrumentos normativos, até aquela data, instituindo o GGI-M, que deve se constituir como um instrumento de gestão para o compartilhamento de estratégias e para a articulação tanto dos órgãos competentes para a implementação das ações sociais e urbanísticas preventivas da violência como das forças de segurança que atuam no território. Segundo Vicente Trevas ${ }^{128}$, ex-

\footnotetext{
${ }^{126}$ Pierson chama também atenção para os casos em que a competição não implica em inovação, mas em um problema de ação coletiva, especialmente nos casos de competição horizontal, em que há uma corrida para baixo (race to the botton) no provimento da política social (PIERSON, 1995, p. 457). Abrucio chama a competição virtuosa na dinâmica federativa de "competição benigna" (2005, p. 44).

${ }^{127}$ Além dessa, são condicionalidades para a adesão dos entes subnacionais ao Pronasci: garantir a participação da sociedade civil e dos conselhos tutelares nos fóruns de segurança pública que acompanharão e fiscalizarão os projetos do Pronasci; participar na gestão e comprometer-se com as diretrizes do Pronasci; compartilhar as ações e as políticas de segurança, sociais e de urbanização; comprometer o efetivo policial nas ações para pacificação territorial, no caso dos estados e do Distrito Federal; disponibilizar mecanismos de comunicação e informação para mobilização social e divulgação das ações e projetos do Pronasci; apresentar plano diretor do sistema penitenciário, no caso dos estados e do Distrito Federal; implementar programas continuados de formação em direitos humanos para os policiais civis, policiais militares, bombeiros militares, servidores do sistema penitenciário e guardas municipais; comprometer-se com centros de referência e apoio psicológico, jurídico e social às vítimas da criminalidade.

${ }_{128}$ Primeiro Encontro Nacional de Gestores do Pronasci, ocorrido em Brasília, nos dias 28 a 30 de julho de 2008. Vicente Trevas ocupou o cargo de assessor especial de Assuntos Federativos do Ministério da Justiça na gestão Tarso Genro, até novembro de 2008.
} 
assessor de assuntos federativos do Ministério da Justiça, espera-se que os Gabinetes conformem uma nova arena institucional de negociação para um processo conjunto de decisão.

Do ponto de vista da dinâmica federativa, uma das questões do Pronasci é se ele se constitui como programa exclusivamente federal ou se ele deve ser implementado como um programa federal-federativo ${ }^{129}$. Nesse sentido, era claro entre os gestores federais do Pronasci, no curso do ano de 2008, a disputa sobre qual deveria ser a centralidade do programa. A Assessoria de Assuntos Federativos do Ministério da Justiça defendia que a centralidade do Pronasci deveria ser a constituição de um novo arranjo federativo na área da segurança pública, por meio do fortalecimento dos gabinetes de gestão integrada, assumindo assim a natureza de programa federal-federativo. Outra parte dos gestores defendia que a centralidade do programa deveria ser a implementação dos projetos desenhados pelo Ministério, configurando-se, o Pronasci, sobretudo, como um programa federal.

Como programa federal-federativo, as ações do Pronasci devem ser apropriadas efetivamente pelos gabinetes de gestão integrada, para que novas decisões compartilhadas reforcem seus pressupostos e enunciados. Como programa apenas federal, o Pronasci se configura pela implementação de ações desenhadas verticalmente pelo governo federal, correndo o risco de resultar numa relação mais de subordinação do que de parceria. Se as arenas decisórias não são compartilhadas entre as diferentes esferas de poder, não se estabelecem redes federativas, mas hierarquias centralizadas. Como afirma Abrucio (2005, p. 46),

[...] a atuação coordenadora do governo federal [...] não pode ferir os princípios básicos do federalismo, como a autonomia e os direitos originários dos governos subnacionais, a barganha e o pluralismo associados ao relacionamento intergovernamental e os controles mútuos.

Como programa federal, o Pronasci induz as instâncias subnacionais a adotarem o programa, que, no caso concreto, tem o mérito de ter sido submetido à apreciação do Congresso Nacional, o que lhe confere maior institucionalidade que o SUSP. Como programa federal-federativo, o Pronasci tem de ser suficientemente flexível para abarcar as variações decorrentes das especificidades das unidades

\footnotetext{
${ }^{129}$ Vicente Trevas chamou atenção várias vezes para este aspecto da questão federativa, no decorrer do ano de 2008.
} 
subnacionais e das decisões coletivas compartilhadas nos gabinetes de gestão integrada.

Para induzir a adesão das unidades subnacionais ao programa, fomentando a cooperação intergovernamental na área da segurança pública, o Pronasci prevê uma série de incentivos, especialmente no que toca à transferência de recursos para os estados e municípios conveniados, com uma contrapartida bastante reduzida quando comparada às contrapartidas exigidas pelo Fundo Nacional de Segurança Pública, que, em geral, giram em torno de $20 \%$. As contrapartidas para os recursos do Pronasci são de $2 \%$ para os estados e municípios das regiões Sul e Sudeste e de $1 \%$ para estados e municípios das demais regiões.

Segundo Arretche (2004), a concentração de autoridade no governo federal apresenta vantagens para a coordenação dos objetivos da política no território nacional, reduzindo as desigualdades horizontais de capacidade de gasto, induzindo escolhas dos governos subnacionais ou limitando estas últimas por meio da instituição de recursos vinculados. Nesse sentido, ao estabelecer exigências para os entes subnacionais que condicionam as transferências de recursos do FNSP e do Pronasci, o governo federal espera conseguir, em alguma medida, sujeitar a sua aplicação a projetos alinhados com suas diretrizes.

Para que os propósitos do Pronasci, enunciados pelo governo, se consolidem na prática e se tornem sustentáveis, os desafios não são pequenos. O Pronasci apresenta potencial para se expandir e para se capilarizar, mas precisará operar recursos e sustentar ações em uma escala que permita transformar o programa em política pública. Em setembro de 2009, cinco estados da federação ainda não integravam o Pronasci e apenas $2 \%$ dos municípios haviam aderido ao programa ${ }^{130}$. Em novembro de 2009, havia na Assessoria de Assuntos Federativos do Ministério da Justiça, 450 solicitações formais de municípios para adesão ao Pronasci aguardando resposta.

No campo das diferentes visões e disputas entre os gestores do Ministério da Justiça, o relato de muitos deles e a observação da dinâmica da gestão do Pronasci apontam deficiências, dificuldades e complexidades em sua gestão por parte do

\footnotetext{
${ }^{130}$ Apesar de pequeno, este percentual não deve ser interpretado de maneira absoluta. É preciso levar em conta que a violência se concentra fortemente nas grandes cidades localizadas em regiões metropolitanas (embora em alguns estados já se verifique um processo de interiorização de alguns tipos de crimes) e que, segundos dados do IBGE (2007), as cidades com mais de 100 mil habitantes representam pouco menos de $5 \%$ do total de municípios brasileiros.
} 
Ministério. Um dos problemas parece referir-se ao fato de que a Secretaria Executiva do Pronasci se vincula diretamente ao Gabinete do Ministro da Justiça, estando fora, portanto, do âmbito da SENASP. No entanto, a execução de grande parte dos projetos é feita por técnicos da SENASP, que nem sempre estão afinados com a visão da Secretaria Executiva do programa.

Outro desafio do Pronasci consiste em conseguir vencer as resistências dos estados a um arranjo institucional que integre, de maneira efetiva, os três níveis de governo. $\mathrm{O}$ arranjo federativo constitucional vigente, que garante a centralidade dos estados no sistema, potencializa resistências estaduais, fortemente enraizadas também culturalmente. Sobretudo os estados dotados de maior capacidade orçamentária e de gestão resistem ao compartilhamento de ações com os municípios e a algumas políticas propostas pelo governo federal. O posicionamento de grande parte dos estados que aderiram ao SUSP e constituíram gabinetes de gestão integrada estaduais tem sido o de não dialogar com os gabinetes de gestão integrada municipais ${ }^{131}$. Os GGI-Es mostram-se refratários à participação dos municípios, procuram preservar suas posições e proteger as políticas que escolhem implementar. Percebe-se, também, a resistência de alguns estados para indicarem representantes de suas polícias para participarem, com algum poder de decisão, dos gabinetes de gestão integrada municipais. Em um dos municípios de São Paulo, por exemplo, os comandos locais das polícias militar e civil recusaram-se, inicialmente, a compor o GGI-M como membros, aceitando participar apenas como convidados ${ }^{132}$. No Rio Grande do Sul, logo após o financiamento de projetos de videomonitoramento aos municípios pelo governo federal, o governo do estado editou a Portaria SJS, de 25 de abril de 2005, subordinando e condicionando qualquer tipo de iniciativa nesse sentido à aprovação prévia da Secretaria de Justiça do Estado. O Colégio Nacional de Secretários Estaduais de Segurança Pública CONSESP, criado em 2003, chegou a emitir resolução posicionando-se contra a

\footnotetext{
${ }^{131}$ Esta foi a fala comum da maior parte dos gestores municipais presentes no Encontro dos Gabinetes de Gestão Integrada, ocorrido em São Paulo, em 15 de agosto de 2008, promovida pelo Ministério da Justiça.

${ }_{132}$ Depoimento de um dos secretários executivos de GGI-M presente no Encontro dos Gabinetes de Gestão Integrada, ocorrido em São Paulo, em 15 de agosto de 2008, promovido pelo Ministério da Justiça. Este problema, quando do relato feito no mencionado encontro, já havia sido resolvido, mas, de forma geral, vários secretários executivos de GGI-Ms, de municípios de toda a parte do país, reclamavam da não indicação de representantes do estado ou da falta do poder de deliberação dos representantes indicados.
} 
publicação de estatísticas criminais pela SENASP ${ }^{133}$. Mais do que tentar evitar num exercício legítimo de fiscalização e controle mútuos entre os três níveis de governo (check and balances) - que alguma instância concentre poder indevido, os estados parecem ainda temer qualquer abalo na centralidade que sempre tiveram no sistema de segurança pública.

O contexto institucional, como ensina Pierson (1995), influencia as estratégias e as opções disponíveis para os atores sociais. O excesso de concorrência, muitas vezes decorrente de disputas partidárias, pode afetar a solidariedade entre as partes, que é o principal ponto do equilíbrio federativo (ABRUCIO, 2005). Em São Paulo, por exemplo, o governo estadual, até o final de 2008, participava de todas as reuniões do GGI do município de São Paulo. Havia um grande esforço cooperativo entre as duas instâncias e a gestão compartilhada de inúmeras ações de segurança. Não obstante, não se verificava a mesma dinâmica entre o governo do estado e os outros 16 municípios que também haviam aderido ao Pronasci no estado, grande parte deles governados por partidos de oposição. Havia, claramente, uma aliança política facilitadora do processo de cooperação entre o governo e a capital, ambos do mesmo partido político, até final de 2008.

As resistências e a falta de consensos nas agendas dos atores, como se analisou no capítulo 4, dificultam não apenas a formação de coalizões reformistas, mas interferem também na qualidade e na potência das mudanças que estão em curso dentro do arranjo institucional vigente. Tomando, por exemplo, um município integrante do Pronasci que recebe recursos para a implantação de um Observatório da Segurança, caso o estado dificulte o compartilhamento de informações criminais, tal fato comprometerá, em certa medida ${ }^{134}$, os diagnósticos locais a serem produzidos, no que diz respeito à compreensão da dinâmica do crime no território. 0 problema é que, sendo a violência multicausal, se não houver cooperação e integração dos múltiplos atores, até mesmo algumas reformas incrementais tendem a ser pouco efetivas. Nesse sentido, ações e projetos integrados de controle e de

\footnotetext{
${ }^{133}$ Informação obtida de um dos gestores da SENASP, em dezembro de 2008. Apesar dos esforços da autora deste trabalho, não foi possível obter, nem junto à SENASP nem mesmo junto à Secretaria Executiva do CONSESP, cópia de suas resoluções. Recentemente, em um curso sobre Convivência Cidadã, promovido pela coordenação da 1‥ CONSEG em julho de 2009, em Campinas, Luiz Flávio Sapori também fez alusão a esse posicionamento do CONSESP.

${ }_{134}$ Compromete em certa medida porque um Observatório não deve trabalhar apenas com uma única fonte de informação, devendo ser capaz de aglutinar e de desenvolver múltiplas fontes.
} 
prevenção do crime dependem, para uma efetiva cooperação, de uma pactuação entre os entes federados (ARANTES; CUNHA, 2003).

Apesar das resistências e das dificuldades, o Pronasci aparece como uma real "possibilidade de inflexão na política de segurança pública, nos próximos anos" (IPEA, 2008, p. 275). Se o Pronasci for bem-sucedido ${ }^{135}$, o protagonismo do governo federal e dos governos municipais na política de segurança pública sairá fortalecido. No entanto, para que um efetivo rearranjo federativo na matéria tenha sustentabilidade e consiga superar as resistências impostas pelo modelo da política de segurança pública, é fundamental que se expresse também na Carta Constitucional, "principal contrato fiador do pacto político-territorial" (ABRUCIO, 2005, p. 43).

\subsubsection{Conferência Nacional de Segurança Pública}

A Constituição Federal de 1988 inaugurou um processo democrático intenso de gestão administrativa. Desde então, foram instituídos conselhos, conferências e comitês gestores visando a possibilitar uma gestão participativa na formulação, execução e fiscalização das políticas públicas.

Desde o início do primeiro mandato do Governo Lula, em 2003, foram realizadas 50 conferências nacionais (tendo como objeto políticas de mulheres, cidades, saúde e juventude, para citar alguns exemplos), com a participação estimada de mais de 4,5 milhões de pessoas, a criação de 19 novos conselhos e a reformulação de nove já existentes. No entanto, a utilização desse dispositivo é inédita em relação à política de segurança pública.

Dando cumprimento à diretriz de seu segundo Programa de Governo, no sentido de promover a democratização e participação da sociedade e do Estado no combate ao crime e à violência, o governo federal, por meio do Ministério da Justiça, deu início, em janeiro de 2008, a um processo interno para a elaboração de um préprojeto de conferência de segurança, com base nas experiências de participação social por meio de conferências. Em 8 de dezembro de 2008, o governo federal,

\footnotetext{
${ }^{135}$ Não é objetivo da presente dissertação fazer uma avaliação dos resultados do programa.
} 
valendo-se de um repertório democrático de gestão participativa e dos efeitos de aprendizagem de conferências anteriormente realizadas, lançou oficialmente para a sociedade brasileira a Primeira Conferência Nacional de Segurança Pública (1 ${ }^{\text {a }}$ CONSEG), que se realizou nos dias 27 a 30 de agosto de 2009, em Brasília.

Segundo o que dispõe o art. $2^{\circ}$ do seu Regimento Interno ${ }^{136}$, o objetivo geral da 1a CONSEG era "definir princípios e diretrizes orientadores da Política Nacional de Segurança Pública, com participação da sociedade civil, trabalhadores e poder público como instrumento de gestão, visando efetivar a segurança como direito fundamental". A expectativa era a de que a conferência pudesse contribuir para inaugurar um amplo debate, nivelando-se a formação sobre o tema entre o conjunto de atores, visando à conformação de um espaço instituinte da Política Nacional de Segurança Pública (KOPITTKE; TORELLY, 2008).

Para planejar e organizar a conferência, o Ministério da Justiça nomeou uma coordenação executiva, contratou mobilizadores para atuar em todo o território nacional e instituiu, em setembro de 2008, uma Comissão Organizadora Nacional

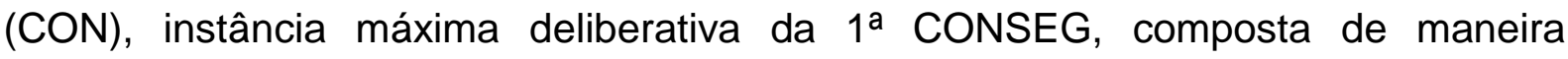
tripartite, com 37 cadeiras distribuídas por três segmentos: sociedade civil, trabalhadores da área de segurança pública e poder público ${ }^{137}$.

Envolveram-se em todo o processo da conferência cerca de 520 mil pessoas, das quais 220 mil eram participantes diretos das várias etapas da conferência. Nas etapas eletivas, os 26 estados da federação e o Distrito Federal promoveram conferências estaduais, e 126 municípios realizaram conferências municipais ${ }^{138}$. Além dessas, foram realizadas 1.140 conferências livres ${ }^{139}, 13$ seminários temáticos e conferências virtuais. (MINISTÉRIO DA JUSTIÇA, 2009c).

Para todo o processo, foi elaborado um Texto Base (MINISTÉRIO DA JUSTIÇA, 2009a) que relacionava sete eixos, em torno dos quais deveriam ser definidas as prioridades para a implementação da política nacional de segurança pública: a) gestão democrática: controle social e externo, integração e federalismo;

\footnotetext{
${ }^{136}$ O Regimento Interno da $1^{\text {ạ }}$ CONSEG está publicado no Relatório Final da $1^{\underline{a}}$ Conferência (Ministério da Justiça, 2009c)

${ }^{137}$ A distribuição completa das cadeiras da CON, por segmento, encontra-se no anexo A.

138 Eram municípios eletivos todos aqueles com mais de 200 mil eleitores, além dos municípios integrantes do Pronasci, independentemente do tamanho de seu colégio eleitoral.

139 As chamadas conferências livres tinham caráter mobilizador e propositivo e podiam ser promovidas pelos mais variados segmentos da sociedade civil, dos trabalhadores da área de segurança pública e do poder público. Das 1.140 conferências livres, 445 foram realizadas por municípios não eletivos. No total, 66.847 pessoas participaram dessas conferências.
} 
b) financiamento e gestão da política pública de segurança; c) valorização profissional e otimização das condições de trabalho; d) repressão qualificada da criminalidade; e) prevenção social do crime e das violências e construção da cultura de paz; f) diretrizes para o sistema penitenciário; g) diretrizes para o Sistema de Prevenção, Atendimentos Emergenciais e Acidentes.

Temas mais polêmicos, como aqueles relacionados a mudanças estruturais no modelo das instituições policiais, não foram contemplados no texto-base. A estratégia, segundo alguns membros da coordenação da conferência, foi a de se evitarem acirramentos entre os atores, para que não se fechassem prematuramente canais de negociação. Não obstante, como se depreende da análise das propostas aprovadas na conferência que será feita a seguir, temas relativos a mudanças estruturais também foram pautados pelos participantes.

Participaram da etapa nacional cerca de 3.000 pessoas, entre representantes eleitos e indicados nas etapas eletivas, com direito a voto ( $40 \%$ de representantes da sociedade civil, $30 \%$ de representantes dos trabalhadores da área de segurança pública e $30 \%$ de representantes do poder público), além de convidados e observadores nacionais e internacionais. Nos quatro dias da etapa nacional, foram discutidos 26 princípios e 364 diretrizes, sistematizadas a partir de todas as propostas elaboradas durante as etapas eletivas e preparatórias da conferência ${ }^{140}$. Ao final da conferência, foram votados, entre todas as propostas debatidas, dez princípios e 40 diretrizes ${ }^{141}$.

Analisando-se, inicialmente, os dez princípios mais votados, que devem nortear a política nacional de segurança pública, percebe-se que eles consagram a tendência de mudanças que vem sendo apontada até aqui. Eles dizem respeito aos seguintes aspectos: integração e envolvimento dos três níveis de governo na política de segurança pública (princípios 1,3,6), reconhecimento jurídico-legal do município como cogestor da segurança (princípio 5), descentralização e integração sistêmica, com a consolidação do SUSP e do Pronasci (princípios 1 e 4); nova concepção de segurança pública, como direito fundamental, pautada pela defesa da dignidade

\footnotetext{
${ }^{140}$ Todas as propostas compiladas integram o Caderno de Propostas da 1a. CONSEG (MINISTÉRIO DA JUSTIÇA, 2009b). Os 26 princípios são gerais e as 364 diretrizes encontram-se separadas nos sete eixos, distribuindo-se da seguinte forma: Eixo1 - 39 diretrizes; Eixo 2 - 55; Eixo 3 - 85; Eixo 4 35; Eixo 5 - 59; Eixo 6 - 48; e Eixo 7 - 43.

141 A íntegra dos dez princípios e 40 diretrizes mais votados pelos participantes da CONSEG encontra-se no anexo $\mathrm{E}$ desta dissertação.
} 
humana, com ênfase na formação humanista dos profissionais da segurança (princípios 3, 4, 8 e 10); ênfase nas políticas sociais preventivas (princípios 6 e 8); sistema nacional de conselhos de segurança independentes, tripartites e participativos, com fortalecimento do controle social (princípio 9); reestruturação do sistema penitenciário (princípio 7); valorização do trabalhador da segurança pública (princípio 10) e reformas no modelo das instituições policiais (princípios 1 e 4).

Quanto às reformas no modelo vigente, o princípio 4 fala expressamente em "promover reformas estruturais no modelo organizacional das instituições de segurança pública", e várias diretrizes que serão a seguir analisadas nomeiam algumas dessas reformas. Não obstante, o segundo princípio mais votado na etapa nacional dispõe que a política nacional de segurança pública deve se pautar pela manutenção da previsão constitucional vigente dos órgãos da área, conforme disposto no artigo 144, da CF, o que pode ser lido como uma preferência pela manutenção do atual modelo. Ou seja, há contradições e uma clara disputa de agendas (que se evidencia também pela análise das respostas dadas pelos atores ao questionário, na seção 4.3, do capítulo 4 desta dissertação).

Com relação às diretrizes, no que diz respeito a reformas estruturais, ao mesmo tempo em que a diretriz 4 postula o ciclo completo da atividade policial para as polícias federais e estaduais, delimitando competências segundo a gravidade do delito, a diretriz 15 afirma o rechaço absoluto à proposta de criação do ciclo completo (a primeira diretriz aprovada com 868 votos e a segunda com 446 votos). Da mesma forma, a diretriz 12 postula desmilitarizar as polícias e desvincular a polícia e corpos de bombeiros das Forças Armadas e a diretriz 3 defende atribuições constitucionais e a autonomia dos Corpos de Bombeiros Militares. A diretriz 15 postula regulamentar as guardas como polícias municipais, mas o princípio 2, como se viu, afirma a manutenção do disposto no artigo 144, da Constituição Federal. Com relação a mudanças no modelo da política de segurança pública, portanto, diretrizes e princípios expressam contradições e ausência de consenso.

Além dessas, as outras diretrizes, relativas aos diversos eixos, dizem respeito, de forma geral, a pautas de modernização da gestão (como reforma nos marcos normativos, modernização dos sistemas de inteligência e informação, incremento nas políticas e tecnologias de combate ao crime organizado, modernização do inquérito policial, reestruturação dos conselhos nos três níveis de governo, modelos 
de financiamento), pautas corporativas (como a melhoria das condições de trabalho, aposentadoria, questões salariais) e pautas de segurança cidadã (que reforçam a importância de políticas preventivas, do combate a todas as formas de discriminação, do policiamento comunitário), além de uma série de medidas relativas ao sistema penitenciário.

Como já foi mencionado na seção 4.3 do capítulo 4, algumas polarizações mostram-se claras, por exemplo, no âmbito da corporações policiais, como o tema do ciclo completo da atividade policial e o da desmilitarização. Por outro lado, também ficou evidente durante a conferência que o tema das reformas policiais, em particular, precisa ser mais discutido, especialmente pela sociedade civil. Nesse sentido, a estratégia de se omitir do texto-base da conferência o tema das reformas no modelo das instituições policiais não contribuiu para ampliar o debate das propostas reformistas estruturais nas etapas preparatórias. ${ }^{142}$ Sem negar a importância histórica e os avanços que seguimentos sociais têm feito na área (ADORNO, 1999, RAMOS, 2007), percebe-se a necessidade de aprofundamento do debate entre os setores organizados da sociedade civil, o que, segundo Mariano (2009), seria o "melhor antídoto para as teses eminentemente corporativistas".

Outro objetivo da CONSEG era o de reestruturar o Conselho Nacional de segurança Pública (CONASP). Criado em 1989 e regulamentado pelo Decreto ํㅡ․ 2.169/1997, o conselho não se reunia desde 2002. À sociedade civil, segundo o Decreto de 1997, estava reservada uma única cadeira na composição do Conselho ${ }^{143}$, ocupada, de forma não obrigatória e sem direito a voz e voto, pelo Conselho Federal da Ordem dos Advogados do Brasil. Um dia antes do início da etapa nacional da CONSEG, em 26 de agosto, foi publicado o Decreto no 6.950, dispondo sobre a composição, estrutura, competências e funcionamento do CONASP. Após a conferência, em 14 de outubro de 2009, o ministro Tarso Genro deu posse aos 48 novos membros provisórios do CONASP, que têm, excepcionalmente, mandato de um ano, com a missão principal de definir regras

\footnotetext{
142 Durante a etapa nacional, em vários momentos de discussão em grupo, representantes da sociedade civil reclamaram da complexidade desse debate, ainda não aprofundado por eles.

${ }^{143}$ Conforme o disposto no mencionado decreto, o CONASP era integrado pelo Ministro da Justiça, pelo Secretário Nacional de Segurança Pública, pelos presidentes dos conselhos regionais de segurança pública, pelo Inspetor Geral das Polícias Militares, pelos diretores do Departamento da Polícia Federal e do Departamento da Polícia Rodoviária Federal, e pelos presidentes do Conselho Nacional dos Chefes da Polícia Civil e do Conselho Nacional de Comandantes Gerais das Polícias Militares e dos Corpos de Bombeiros Militares. Ficava facultada à OAB Federal e ao Ministério Público Federal a indicação de um representante cada, sem direito a voz e voto.
} 
para a escolha dos órgãos e entidades que farão parte do conselho permanente, a partir de 2010. Os 48 integrantes provisórios ocupam 39 cadeiras com direito a voto, divididas entre os seguintes seguimentos: $40 \%$ da sociedade civil, $30 \%$ do poder público e $30 \%$ dos trabalhadores da área. A composição é a mesma da Comissão Organizadora Nacional da $1^{\text {a }}$ CONSEG, ficando a presidência a cargo do Ministro da Justiça.

A conferência e a reestruturação do CONASP contribuem para democratizar, de maneira inédita, o debate e a gestão da segurança pública no país. A 1ạ . CONSEG conformou-se como um importante mecanismo institucional para ampliar o debate público e para favorecer o diálogo entre os múltiplos atores da comunidade da política de segurança pública. Do ponto de vista das agendas, a 1a. CONSEG, para além de explicitar polarizações, contradições e a necessidade da continuidade e aprofundamento do debate sobre as várias questões relevantes pautadas durante o processo, deixou manifesto em seus princípios que as mudanças que estão sendo implementadas processualmente, ao longo especialmente da última década e meia, começam a se consolidar na visão dos atores da comunidade da política. 


\section{Conclusão}

A política de segurança pública no Brasil apresenta várias características engendradas historicamente, tais como o padrão dual e fragmentado das instituições policiais, a militarização do policiamento ostensivo e a centralização da segurança pública nos estados. No período constituinte de 1987-1988, que se apresentava como uma janela de oportunidades para mudanças, estavam em jogo interesses de grupos poderosos que marcavam a relação entre o governo de transição e os militares, o que contribuiu para que prevalecessem as preferências pela manutenção do status quo no desenho das instituições de segurança. À época, o tema da segurança pública era restrito quase que exclusivamente às instituições responsáveis pela manutenção da lei e da ordem, sob a égide do paradigma repressivo-punitivo de enfrentamento do crime.

A crise da segurança pública nas décadas de 1980 e 1990 explicitou a insuficiência e o esgotamento do modelo tradicional de segurança pública para fazer frente à criminalidade contemporânea, mas nenhuma das propostas de reforma estrutural dessa política, apresentadas por diferentes atores, obteve êxito até o presente momento. Nas políticas públicas, as escolhas passadas ajudam a conformar as preferências dos atores. Mudanças na política são possíveis, porém, em razão do contexto histórico e do padrão de dependência da trajetória, tendem a inovações limitadas. A existência de uma comunidade da política composta por atores com múltiplas e polarizadas posições e a falta de debate público sobre o atual modelo da política e das instituições policiais também não favorece a constituição de uma ampla coalizão em torno de uma agenda mínima de reformas. Todos esses aspectos, aliados à sensibilidade dessa arena política, ajudam a explicar a resistência da política de segurança pública a mudanças estruturais.

A partir do Governo FHC, a política de segurança pública entrou para a agenda federal. Durante os dois mandatos de FHC, conjunturas críticas anteciparam a implementação de pontos importantes da agenda governamental e criaram um campo propício para a aprovação de projetos de lei que se arrastavam no tempo, polarizando a preferência dos atores. Os direitos humanos ocuparam a centralidade da agenda. Várias medidas importantes foram tomadas nessa área, tais como a 
criação da Secretaria Especial de Direitos Humanos e a elaboração de dois Programas Nacionais de Direitos Humanos. Muitas das ações neles previstas traziam conteúdos impactantes para a segurança pública, especialmente porque foi em resposta a situações de grande violação de direitos humanos por agentes públicos de segurança que se construiu grande parte dessa agenda. Foram criadas a SENASP e o Fundo Nacional de Segurança Pública e lançou-se o primeiro Plano Nacional de Segurança Pública. Apesar dos poucos resultados alcançados, o governo federal passou a se constituir como um novo ator relevante da comunidade da política, e o tema de uma política nacional de segurança pública ingressou na agenda política, pela primeira vez em período democrático.

O primeiro Governo Lula teve início com um programa radical no que tange a reformas no modelo da política de segurança pública. Suas propostas, no entanto, não chegaram a entrar para a agenda decisional do governo. Para além do alto custo de reversão da política, não existia uma coalizão reformista para dar sustentação ao processo de mudanças. Para o neoinstitucionalismo histórico, as burocracias públicas estão em uma posição privilegiada para articular coalizões majoritárias em torno de uma agenda reformista (ORLOFF, 1998; SCKOPOL, $1985)^{144}$. O Presidente da República e o primeiro escalão da burocracia governamental são atores relevantes e estão numa posição vantajosa para reconhecerem como legítimas determinadas correntes de uma comunidade política e para articular em torno delas a construção de uma coalizão. Porém, naquele momento, o Governo Lula não assumiu essa tarefa, e se construíram caminhos alternativos em torno de importantes mudanças incrementais.

O Sistema Único de Segurança Pública, na prática, conseguiu, em diferentes medidas, induzir em alguns estados, maior integração operacional entre as polícias $^{145}$ e promoveu um movimento bastante significativo em direção a uma melhor formação e capacitação dos profissionais da segurança pública.

\footnotetext{
${ }^{144}$ Para as autoras, as burocracias públicas não podem reformar sozinhas uma política, mas são atores privilegiados para liderar coalizões.

${ }_{145}$ Integrar as polícias estaduais não é o mesmo que unificar o sistema. Um sistema unificado depende, no caso em estudo, do efetivo reconhecimento dos novos atores políticos, governo federal e municípios, superando-se, inclusive, as resistências dos estados. Significa uma efetiva coordenação pelo governo federal, com sua capacidade de induzir políticas e de fomentar a cooperação intergovernamental, respeitadas as autonomias dos estados e municípios e as especificidades locais. Significa uma gestão efetivamente articulada e sistêmica nos três níveis de governo.
} 
Especialmente na última década, vários municípios pautaram a política de segurança pública em suas agendas. Reorganizaram-se administrativamente, criando órgãos gestores da política de segurança e conselhos municipais, implementaram políticas locais intersetoriais de prevenção da violência e conferiram maior profissionalização e especialização a suas guardas. O segundo Governo Lula teve o mérito de incorporar essas experiências inovadoras de gestão e de reconhecer os municípios como novos atores da política por ocasião da elaboração do Pronasci. Com a instituição do programa, o governo federal procurou articular os três níveis de governo, a despeito de algumas dificuldades de gestão em sua implementação e da resistência de alguns atores. Foram instituídos mecanismos de indução para adesão ao programa pelos estados e municípios, estabelecendo, por exemplo, contrapartidas quase simbólicas para o financiamento dos projetos e condicionando o recebimento de recursos do Pronasci e do FNSP à instalação de gabinetes de gestão integrada.

A primeira Conferência Nacional de Segurança Pública lançou mão de um repertório de dispositivos já utilizados em outras políticas públicas, visando à democratização e ampliação do debate e à produção de novos acordos na área. No que diz respeito às reformas estruturais no modelo das instituições policiais, a conferência explicitou contradições, polarizações e a necessidade de se ampliar e aprofundar o debate. Por outro lado, a maior parte dos princípios eleitos para nortear a construção de uma política nacional aponta para o fortalecimento das mudanças em curso nos últimos anos, versando sobre os seguintes pontos: integração dos três níveis de governo na gestão da segurança pública; coordenação e cooperação intergovernamental (que se expressaram na defesa da consolidação do SUSP e do Pronasci); nova concepção de segurança pública pautada pela defesa da dignidade humana; ênfase nas políticas sociais preventivas de forma complementar à repressão qualificada e democratização da gestão, com participação e maior controle social.

De forma inaugural no Governo FHC e de maneira mais efetiva no Governo Lula, as mudanças incrementais ocorreram nessa direção. Soares (2007, p. 92) aponta que, para além das diferenças no tratamento de princípios, desde o plano do segundo governo de FHC, 
[...] tem havido mais continuidade do que descontinuidade entre os esforços sucessivos, que já formam uma série histórica tão mais relevante quão mais se distingue do período anterior, ainda fortemente marcado por reverente omissão, relativamente à área - tabu - da Segurança Pública. (SOARES, 2007, p. 92)

A continuidade do esforço por mudanças acaba por gerar efeitos que alteram a composição dos atores no campo, seus recursos e suas preferências, de tal maneira que mudanças lentas e processuais podem acabar por gerar efeitos políticos de longo prazo. (PIERSON, 2006).

Desde os anos 1990, a comunidade da política de segurança vem se ampliando e propondo novas práticas de controle e prevenção do crime e da violência que demandam a articulação de vários e de novos atores políticos e sociais. Tanto o governo federal, com sua capacidade de induzir a adoção de políticas e de promover maior coordenação e cooperação intergovernamental, como os municípios, com sua vocação para a implementação de políticas preventivas, passaram a pautar o tema da segurança pública em suas agendas, tornando-se atores relevantes dessa comunidade. Emergiram no campo atores sociais com agendas propositivas. Foram criadas ouvidorias de polícias, apesar disso não ter ocorrido para todas as polícias, nem em todos os estados e nem com a independência investigativa desejada. Uma série de mudanças incrementais e novas experiências de gestão começaram a ser engendradas. Os atores não se posicionam como blocos monolíticos. Continuam havendo fortes polarizações nas agendas, mas começam a se constituir também algumas confluências. O CONASP, que antes reservava assento a um único ator social sem direto a voz e voto, tem agora uma composição tripartite, em que a sociedade civil ocupa $40 \%$ das cadeiras, frente aos $30 \%$ de assentos reservados aos trabalhadores e $30 \%$ aos gestores. Pela primeira vez, abriu-se um amplo debate nacional sobre as diretrizes de uma política nacional de segurança pública. $O$ ingresso de novos atores políticos e sociais na comunidade da política de segurança pública alterou a configuração do campo. O paradigma repressivo-punitivo não saiu de cena, mas a entrada no campo do paradigma da segurança cidadã provocou uma fissura em sua histórica hegemonia.

Todas essas inovações provocaram alterações em algumas características tradicionais da política de segurança pública e promoveram pequenos deslocamentos em sua dinâmica federativa. Esses pequenos deslocamentos não promoveram mudanças estruturais no modelo da política nem ensejaram a alteração 
do texto constitucional. Provocaram, porém, ruídos, perturbaram o campo tradicional da política, sem alterar seu núcleo duro, sem alterar o modelo e as principais características das instituições policiais.

De forma geral, as taxas de criminalidade no Brasil permanecem elevadas e assim também a impunidade e a violência policial ${ }^{146}$. Os mecanismos de controle externo e interno das instituições policiais continuam frágeis e são ainda recorrentes os conflitos entre essas instituições ${ }^{147}$. Tudo isso mostra que, até o momento, as mudanças incrementais implementadas não apresentam, de forma homogênea em todo o país, alto impacto do ponto de vista de seus resultados ${ }^{148}$. Sem reformas estruturais no modelo da política, isto é, aquelas capazes de afetar "os princípios, as estruturas e as regras duras de uma dada política" (DRAIBE, 2003, p. 67), até mesmo as mudanças realizadas até aqui podem não ter sustentabilidade, tendendo a depender de fatores conjunturais para alcançar resultados positivos.

É preciso consolidar os avanços já obtidos, inclusive de forma a garantir sua expressão no texto constitucional. É preciso dar seguimento às reformas incrementais em curso ou ainda não implementadas, que possam qualificar a gestão e fortalecer a integração. E é preciso ir além. O desafio no campo da política de segurança pública consiste em ampliar o debate nacional, apenas iniciado com a primeira conferência, e em fazer com que atores - com interesses corporativos e polarizados e numa arena política tão sensível - sejam capazes de costurar uma

\footnotetext{
146 Segundo Ramos (2007), o uso da força letal pela polícia do Rio de Janeiro aumentou enormemente na década de 2000. Só no ano de 2006, a polícia do Rio de Janeiro foi responsável por $14 \%$ das mortes violentas intencionais. Nesse estado, em seis anos, de 1999 a 2006, os registros de "resistência seguida de morte", referentes a mortes em confronto com a polícia, aumentaram $280 \%$, de 289, em 1999, para 1.063, em 2006.

${ }_{147}$ Exemplo de que as mudanças incrementais implementadas não têm sido suficientes para encerrar os históricos conflitos entre as corporações policiais, é dado pelo já mencionado confronto ocorrido entre policiais civis e militares, em 16 de outubro de 2008, em São Paulo, estado que aderiu ao SUSP e que tem adotado algumas medidas para melhor integração de suas polícias. Segundo Battibugli (2008), mais do que a simples tentativa de levar reivindicações salariais ao governador, o mencionado episódio expressa a antiga e duradoura rivalidade existente entre as duas corporações.

${ }^{148}$ Vale notar que os crimes de homicídio na presente década apresentam uma tendência de queda, em alguns estados, como São Paulo e Pernambuco, mantendo tendência de curva ascendente em outros, como Pará, Alagoas, Bahia e Maranhão (NÚCLEO DE ESTUDOS DA VIOLÊNCIA, 2009). No caso dos estados em que o número de homicídios decresceu sensivelmente, como São Paulo, separar as variáveis explicativas desse fenômeno e o peso de cada uma delas sobre os resultados é tarefa difícil, uma vez que a violência é multicausal e, em consequência, seu enfrentamento depende de ações e políticas multissetoriais. Sobre algumas hipóteses explicativas para o fenômeno, cf. Adorno, 2009. Mesmo nesses casos em que a curva de homicídios tem apresentado tendência descendente, será necessário um tempo histórico maior tanto para se analisar a durabilidade dessa tendência como para se analisar se com ela diminuirão também a corrupção, a impunidade, a violência policial e outras modalidades criminosas que vulneram o Estado Democrático de Direito.
} 
ampla coalizão em torno de uma agenda mínima de reformas estruturais no modelo da política de segurança pública. Esta é uma agenda ainda inconclusa. 


\section{REFERÊNCIAS BIBLIOGRÁFICAS}

ABRUCIO, Fernando Luiz. A coordenação federativa no Brasil: a experiência do período FHC e os desafios do governo Lula. Revista de Sociologia Política, Curitiba, 24, p. 41-67, jun. 2005.

Reforma política e federalismo: desafios para a democratização brasileira. In: BENEVIDES, Maria Victoria VANNUCHI, Paulo; KERCHE, Fábio (Org.). Reforma política e cidadania. São Paulo: Instituto Cidadania; São Paulo: Fundação Perseu Abramo, 2003.

; GAETANI, Francisco. Avanços e perspectivas da gestão pública nos estados: agenda, aprendizado e coalizão. Bresser Pereira Website. São Paulo, 2006. Disponível em: <www.bresserpereira.org.br/Documents/MARE/TerceirosPapers/Texto\%20de\%20Abrucio\%20e\%20de\%20Gaetani.pdf>.

ADORNO, Sérgio. Insegurança versus direitos humanos: entre a lei e a ordem. In: Tempo Social, Revista de Sociologia da USP, São Paulo, v. 11, n. 2, p. 129-153, 1999.

. Exclusão socioeconômica e violência urbana. Sociologias, Porto Alegre, $\mathrm{n}$. 8, jul./dez. 2002.

. Lei e ordem no segundo governo FHC. In: Tempo Social, Revista de Sociologia da USP, São Paulo, v. 15, n. 2, p. 103-140, nov. 2003.

- Políticas públicas de segurança e justiça penal. In: Segurança Pública. Cadernos Adenauer IX, Rio de Janeiro, n. 4, 2009, Fundação Konrad Adenauer.

; IZUMINO, Wania. Fontes de dados judiciais. In: CERQUEIRA, Daniel; LEMGRUBER, Julita; MUSUMECl, Leonarda (Org.). Fórum de debates: criminalidade, violência e segurança pública no Brasil: uma discussão sobre as bases de dados e questões metodológicas. Rio de Janeiro: IPEA, Rio de Janeiro: CESeC/UCAM, nov. 2000. Disponível em:

$<$ http://www.cibera.de/fulltext/4/4625/Encontro.pdf>.

ALBERNAZ, Elizabete. Reflexões sobre a investigação brasileira através do Inquérito Policial. In: COORDENAÇÃO GERAL DA 1ㄹ. CONSEG (Org.) Reflexões sobre a investigação brasileira através do inquérito policial. Cadernos Temáticos da Conseg. Brasília, Ministério da Justiça, ano 1, n. 6, 2009. 
ALMEIDA, Maria Hermínia Tavares. Recentralizando a federação? In: Revista de Sociologia e Política, Curitiba, n. 24, p. 29-40, 2005.

ALVAREZ, Marcos Cesar; SALLA, Fernando; SOUZA, Luiz Antonio. Políticas de segurança pública em São Paulo: uma perspectiva histórica. In: Justiça \& História, Porto Alegre, 4 (8): 173-199, 2004.

ARANTES, Rogério Bastos; CUNHA, Luciana Gross Siqueira (2003). Polícia civil e segurança pública. Problemas de funcionamento e perspectivas de reforma. In: SADEK, Maria Tereza (Org.). Delegados de polícia. São Paulo: Sumaré.

ARENDT, Hannah. Crises da República. São Paulo: Perspectiva, 2004.

ARRETCHE, Marta. Federalismo e políticas sociais no Brasil: problemas de coordenação e autonomia. In: São Paulo em Perspectiva, São Paulo, v. 18, n. 2, p. 17-26, jun. 2004.

The veto power the sub-national governments in Brazil: Political institutions and parliamentary behavior in the post-1988. Brazilian Political Science Review, Rio de Janeiro, n. 2, 2007.

; VAZQUEZ, Daniel; GOMES, Sandra. (no prelo). Descentralização e autonomia: deslocando os termos do debate. In: LAVALLE, Adrian. (Org.). $O$ horizonte da política: questões emergentes e agenda de pesquisa. São Paulo: Cosac Naify. Não paginado.

ARRIAGADA, Irma; GODOY, Lorena. Prevenir o reprimir: falso dilema de la seguridad ciudadana. Revista de la CEPAL, Santiago, CL, n. 70, abr. 2000.

ARTURI, Carlos. O debate teórico sobre mudança do regime político: O caso brasileiro. Revista de Sociologia e Política, Curitiba, n. 17, p. 11-31, 2001.

BATTIBUGLI, Thaís. Democracia e segurança pública no estado de São Paulo (1946-1964). Tese de doutorado. Departamento de Ciência Política: Universidade de São Paulo, 2006.

\footnotetext{
Brasileiro de Segurança Pública, 2008. Disponível em: $<$ www.forumseguranca.org.br/artigos/confronto-entre-policia-civil-e-militar-em-saopaulo.>.
} 
BERCOVICI, Gilberto. Dilemas do Estado Federal Brasileiro. Porto Alegre: Livraria do Advogado, 2004.

BICUDO, Hélio. A unificação das polícias no Brasil. In: Estudos Avançados, ano 14, n. 40, São Paulo, Instituto de Estudos Avançados/Universidade de São Paulo, set.dez. 2000.

BORJA, Jordi. La ciudad conquistada. Madrid: Alianza Editorial, 2003.

. Espacio público y espacio político. In: DAMMERT, L. (Org.). Seguridad Ciudadana: Experiencias y Desafíos. Red 14 - Seguridad Ciudadana en la Ciudad. Chile: Programa URB-AL, 2004.

BÚVINIC, Mayra; MORRISON, Andrew; SHIFTER, Michael. La violencia en America Latina y el Caribe: Un marco de referencia para la acción. Banco Interamericano de Desenvolvimento (BID). Washington: DC, s/d.

BURRIS, S.; DRAHOS, P.; SHEARING, C. Nodal governance. In: The Australian Journal of Legal Philosophy, Camberra, Australia, n. 30, p. 30-58, 2005.

CALDEIRA, Tereza Pires do Rio. Cidade de muros: crime, segregação e cidadania em São Paulo. São Paulo: 34; São Paulo: Edusp, 2003.

CANO, Inácio. Políticas de segurança pública no Brasil: tentativas de modernização e democratização versus a guerra contra o crime. In: SUR - Revista Internacional de Direitos Humanos, São Paulo, ano 3, n. 5, 2006. Disponível em: $<$ www.surjournal.org $>$.

CAPELLA, Ana Cláudia. Perspectivas teóricas sobre o processo de formulação de políticas públicas. In: HOCHMAN, Gilberto; ARRETCHE, Marta; MARQUES, Eduardo (Org.). Políticas públicas no Brasil. Rio de Janeiro: Fiocruz, 2007.

CARBALLO BLANCO, Antonio Carlos. Sistema e funções de segurança pública no Brasil. In: CERQUEIRA, Daniel; LENGRUBER, Julita; MUSAMECI, Leonarda (Org.). Fórum de debates criminalidade, violência e segurança pública no Brasil: uma discussão sobre as bases de dados e questões metodológicas. Rio de Janeiro: CeSEC/IPEA, 2000. 
CARDOSO, Fernando Henrique. Mãos à obra, Brasil: proposta de governo. In: Centro Edelstein de pesquisas sociais, 1994. Disponível em: $<$ www.centroedelstein.org.br>.

Avança, Brasil: Proposta de Governo. Disponível em: In: Centro Edelstein de pesquisas sociais, 1998. Disponível em: <www.centroedelstein.org.br>.

CARVALHO, José Murilo. Cidadania no Brasil: o longo caminho. Rio de Janeiro: Civilização Brasileira, 2003.

CARTWRIGHT, John; JENNEKER, Madeleine. Mobilização de conhecimento e de capacidade local por meio da segurança. In: SLAKMON, C. et al. (Org.) Novas direções na governança da justiça e da segurança. Brasília: Ministério da Justiça/Secretaria da Reforma do Judiciário, 2006.

CHRISTIE, Nils. Elementos para uma geografia penal. Revista de Sociologia e Política, Curitiba, n. 13, nov. 1999.

DALLARI, Dalmo de Abreu. O pequeno exército paulista. São Paulo: Perspectiva, 1977.

A polícia civil no Estado brasileiro. In: MORAES, Bismael (Org.) A polícia à luz do direito. São Paulo: Revista dos Tribunais, 1991.

DAMMERT, Lucía. Seguridad Ciudadana: Experiencias y Desafíos. Red 14 "Seguridad Ciudadana en la Ciudad". Chile: Programa URB-AL, 2004.

; PAULSEN, Gustavo (Org.) Ciudad y seguridad en América Latina. Chile: URBAL- RED 14; Chile: FLACSO, 2005.

DIAS NETO, Theodomiro. Segurança urbana: o modelo da nova prevenção. São Paulo: Revista dos Tribunais; São Paulo: FGV, 2005.

DRAIBE, Sonia. A política social do governo FHC e o sistema de proteção social. In: Revista Tempo Social, Revista de Sociologia da USP, São Paulo, v. 15, n. 2, p. 63101, 2003. 
DUPONT, Benoît. As redes de segurança. In: SLAKMON, C. et al. (Org.) Novas direções na governança da justiça e da segurança. Brasília: Ministério da Justiça/Secretaria da Reforma do Judiciário, 2006.

DURANTE, Marcelo Ottoni. Gestão de burocracias públicas: um estudo de caso da Secretaria Nacional de Segurança Pública. Tese de doutorado. Departamento de Ciências Humanas. Belo Horizonte: Universidade Federal de Minas Gerais, 2008.

; ZAVATARO, Bruno. Limites e desafios da evolução da gestão em segurança pública no Brasil: a importância do uso de indicadores de avaliação de desempenho. São Paulo em Perspectiva, São Paulo, v. 21, n. 1, p. 76-91, jan./jun. 2007.

Disponível em: <http://www.seade.gov.br/produtos/spp/v21n01/v21n01_06.pdf>.

FECOMÉRCIO Pesquisa sobre segurança pública no Brasil. Rio de Janeiro, $2008 . \quad$ Disponível em: <http://pdba.georgetown.edu/Security/citizensecurity/brazil/documents/fecomercio.pdf>.

FERNANDES, Edésio. Gestão metropolitana. In: Cadernos da Escola do Legislativo, Belo Horizonte, Assembleia Legislativa do Estado de Minas Gerais, v. 7, n.12, p. 6899, 2004.

FRENTE NACIONAL DE PREFEITOS - FNP. A segurança pública e os municípios. Relatório do Grupo de Trabalho de Segurança Pública do Comitê de Articulação Federativa. Outubro de 2003. Atualização do debate. Brasília, mar. 2004. Disponível em: <http://www.fnp.org.br/?op=int_documentos\&id=35\&mod=documentos $>$.

FÓRUM EUROPEU DE SEGURANÇA URBANA. Manifesto de las Ciudades para la "Seguridad \& Democracia". Nápoles: 7-9 dez. 2000, (mimeo).

FÓRUM NACIONAL DE OUVIDORES DE POLÍCIA. Proposta de Projeto de Emenda Constitucional sobre um novo modelo de polícia no Brasil. Brasília: FNOP, Secretaria Especial de Direitos Humanos e Centro Santo Dias de Direitos Humanos, 2000.

FREY, Klaus. Políticas públicas: um debate conceitual e reflexões referentes à prática da análise de políticas públicas no Brasil. In: IPEA - Instituto de Pesquisa Econômica Aplicada, 2002.2 Disponível em: $<$ http://www.ipea.gov.br/pub/ppp/ppp21/Parte5.pdf>. 
; CZAJWOSKI, Sérgio. O município e a segurança pública: o potencial da governança urbana. In: LYRA, Rubens (Org.). Participação, democracia e segurança pública: a experiência brasileira. João Pessoa: UFPB, 2008.

GARLAND, David. La cultura Del control: crimen y orden social en la sociedad contemporánea. Barcelona: Gedisa, 2005.

GONÇALVES, Ligia Maria Daher. Gestão participativa e integração de políticas públicas: condições para uma política municipal proativa. In: MARIANO, Benedito. Por um novo modelo de polícia no Brasil: a inclusão dos municípios no sistema de segurança pública. São Paulo: Fundação Perseu Abramo, 2004.

GROSSI DE SOUZA, Bruno César. Orçamento e segurança pública: um estudo de caso do Fundo Nacional de Segurança Pública. Monografia de especialização. Núcleo de Pesquisa em Políticas Públicas: Universidade de Brasília, 2004.

HALL, Peter; TAYLOR, Rosemary. As três versões do neoinstitucionalismo. Lua Nova: Revista de Cultura e Política, São Paulo, n. 58, p. 193-223, 2003. Disponível

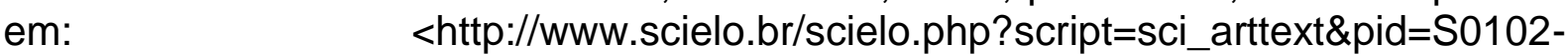
$64452003000100010 \& \operatorname{lng}=e n \& n r m=i s o>$.

IBGE. Pesquisa de informações básicas municipais: perfil dos municípios brasileiros 2006. Rio de Janeiro: Ministério de Planejamento, Orçamento e Gestão, 2007.

IMMERGUT, Ellen. As regras do jogo sociológico: a lógica da política de saúde na França, na Suíça e na Suécia. Revista Brasileira de Ciências Sociais, São Paulo, n. 30, ano 11, fev. 1996.

INSTITUTO CIDADANIA. Projeto segurança pública para o Brasil. São Paulo: Instituto Cidadania, 2002.

IPEA. Segurança pública. In: Políticas sociais: acompanhamento e análise, n. 6, fev. 2003. Disponível em: $<$ <ttp:/wnw.ipea.gov.br/sites/000/2/publicacoes/bpsociais/bps_06/SEGURANcA_PuBLICA.pdfs.

IPEA. Políticas sociais: acompanhamento e análise, n. 16, nov. 2008. Disponível em: $<$ http://www.oei.es/pdf2/politicas-sociais-acompanhamento-analise.pdf>.

KAHN, Túlio; ZANETIC, André. O papel dos municípios na segurança pública. Série Estudos Criminológicos 4. Relatório final. Concursos nacionais de pesquisas 
aplicadas em justiça criminal e segurança pública, 2005. Disponível em: $<$ http://www.mj.gov.br/main.asp?View=\{B5043148-897A-45EA-BA14-

A76FC4D95D58\}>.

KANT DE LIMA, Roberto; MISSE, Michel; MIRANDA, Ana Paula Mendes. Violência, criminalidade, segurança pública e justiça criminal no Brasil: uma bibliografia. Revista Brasileira de Informação Bibliográfica em Ciências Sociais, Rio de Janeiro, n. 50, 2을 semestre, p. 45-123, 2000.

KFOURI FILHO, Abrahão José. A polícia civil e sua constitucionalização no direito brasileiro. In: MORAES, Bismael (Org.) A polícia à luz do direito. São Paulo: Revista dos Tribunais, 1991.

KINZO, Maria Dalva; BRANDÃO, Gildo Marçal; SADEK, Maria Tereza; ARRETCHE, Marta; POLESI, Alexandre. Análise retrospectiva: dimensão institucional. São Paulo: Instituto de Estudos Avançados/Universidade de São Paulo, 2004. Disponível em: $<$ www.iea.usp.br/observatorios/futuro $>$.

KOPITTKE, Alberto; TORELLY, Marcelo Dalmás. Políticas públicas para a segurança com participação: esboço sobre a Conferência Nacional de Segurança Pública com Cidadania. In: Violência e controle social na contemporaneidade, Volume III - Anais do III Ciclo de Estudos e Debates sobre Violência e Controle Social. Porto Alegre: EdiPUCRS, 2008, p. 99-114, 2008.

KOWARICK, Lúcio. Viver em risco: sobre a vulnerabilidade no Brasil urbano. Novos Estudos, CEBRAP, São Paulo, n. 63, jul. 2002.

LEAL, Victor Nunes. Coronelismo, enxada e voto: o município e o regime representativo no Brasil. 3. ed. Rio de Janeiro: Nova Fronteira, 1977.

LEMGRUBER, Julita. Como salvar o plano. O Globo, Rio de Janeiro, 21 set. 2000.

. Violência, omissão e insegurança pública: o pão nosso de cada dia. Trabalho apresentado na Academia Brasileira de Ciências. Rio de Janeiro, jun. 2004. In: CESeC - Centro de Estudos de Segurança e Cidadania. Disponível em: <http://www.ucamcesec.com.br/pb_txt_dwn.php>.

LEMLE, Marina. Unificação das polícias emperra em Brasília. In: Comunidade segura: rede de ideias e práticas em segurança humana, 2007. Disponível em: $<w w w . c o m u n i d a d e s e g u r a . o r g / ? q=p t /$ node/32757>. 


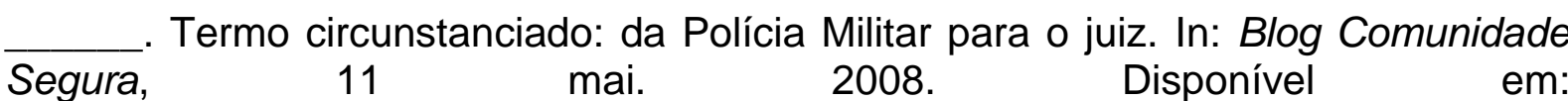
<http://blog.comunidadesegura.org/policiaesociedade /2008/05/11/termocircunstanciado-da-policia-militar-para-o-juiz/>.

LÉVY, René. Polícia e justiça penal na França: os motivos de uma crise. In: LIMA, Roberto Kant et al. (Org.). Reflexões sobre segurança pública e justiça criminal numa perspectiva comparada. Brasília: Secretaria Especial de Direitos Humanos, 2008.

LIMA, Amaro. Governabilidade e o Padrão Dual da Segurança Pública no Brasil (1831-1850). Revista Acadêmica Política Hoje, Recife, v. 1, n. 15, 2006.

MACHADO, Gustavo Gomes; SOUKI, Léa Guimarães; FARIA, Carlos Aurélio Pimenta. Processo legislativo, articulação intergovernamental e gestão metropolitana: inovação institucional e participação social na região metropolitana de Belo Horizonte. In: XIII Congresso Brasileiro de Sociologia, Recife, UFPE, 2007. Disponível em: <http://www.sbsociologia.com.br/congresso_v02/papers/GT2\%20Cidades\%20e\%20 Processos\%20Sociais/Paper_SBS_2007_Gustavo,_Lea_e_Carlos_Aur\%C3\%A9lio.p df $>$.

MARIANO, Benedito Domingos. O que alimenta a violência? Folha de S.Paulo, São Paulo, 6 mai. 1998.

. Corrupção só acaba com mudança das estruturas. A Tribuna, 21 mai. 1999.

. Por um Ministério da Segurança Pública. In: Centro de Comunicação Social do Exército, 2006. Disponível em: <www.exercito.gov.br/resenha/Complemento\%20anterior\%20word/arquivos/2006/Ju n/Complemento\%2001\%20Jun\%2006.doc>.

Por um novo modelo de polícia no Brasil: a inclusão dos municípios no sistema de segurança pública. São Paulo: Fundação Perseu Abramo, 2004.

. Primeiro passo. O Estado de S. Paulo, São Paulo, 14 set. 2009.

MEDEIROS, Mateus Afonso. Aspectos Institucionais da Unificação das Polícias no Brasil. Dados - Revista de Ciências Sociais, Rio de Janeiro, v. 47, n. 2, p. 271-296, 2004. 
MELO, Marcos André. O sucesso inesperado das reformas de segunda geração: federalismo, reformas constitucionais e política social. Dados - Revista de Ciências Sociais, Rio de Janeiro, v. 8, n. 4, p. 845-889, 2005.

MENICUCCI, Telma Maria Gonçalves. Público e privado na política de assistência à saúde no Brasil: atores, processos e trajetórias. Rio de Janeiro: Fiocruz, 2007.

MESQUITA NETO, Paulo. Prevenção do crime e violência e promoção da Segurança Pública no Brasil. In: Arquitetura institucional do Sistema Único de Segurança Pública. Brasília: Ministério da Justiça/SENASP, 2004.

; AFFONSO, Beatriz. Segundo Relatório Nacional sobre os Direitos Humanos no Brasil. São Paulo: Comissão Teotônio Vilela de Direitos Humanos, 2002.

; RICARDO, Carolina Mattos. O Fórum metropolitano de segurança pública e a ampliação do debate sobre a violência em São Paulo. Lusotopie, Paris, p. 365-382, 2003.

. Mortes a esclarecer, crises a evitar. In: NOGUEIRA, Rose (Org.). Crimes de maio. São Paulo: Condepe, 2006.

MILANI, Aloisio. Lei de crimes hediondos mudou após casos de comoção nacional, mostram estudos. In: Agência Brasil, 14 fev. 2007. Disponível em:

http://agenciabrasil.ebc.com.br/noticia/2007-02-14/lei-de-crimes-hediondos-mudouapos-casos-de-comocao-nacional-mostram-estudos.

MINISTÉRIO DA JUSTIÇA. Matriz Curricular Nacional para formação das Guardas Municipais. Brasília: SENASP/MJ, 2005. Ministério da Justiça. Disponível em: $<w w w . m j . g o v . b r / s e r v i c e s / D o c u m e n t M a n a g e m e n t / F i l e D o w n l o a d . E Z T S v c . a s p ? D o c u m$ entID=\%7BDEA3DC2E-6413-4E48>.

Perfil das organizações da segurança pública: relatório descritivo. Brasília: SENASP/Ministério da Justiça, 2007a.

Relatório de atividades: implantação do Sistema Único de Segurança Pública. Secretaria Nacional de Segurança Pública - 2003 a 2006. Brasília: SENASP/Ministério da Justiça, 2007b. 
Relatório de atividades: implantação do Sistema Único de Segurança Pública. Secretaria Nacional de Segurança Pública - 2007. Brasília: SENASP/Ministério da Justiça, 2008a. (Não publicado).

. Gabinetes de gestão integrada em segurança pública. Brasília: SENASP/Ministério da Justiça, 2008b. (Não publicado).

- Texto-Base da 1ạ. Conferência Nacional de Segurança Pública. Brasília: Ministério da Justiça, 2009a.

- Caderno de Propostas da 1ạ. Conferência Nacional de Segurança Pública. Brasília: Ministério da Justiça, 2009b.

Relatório Final da 1a. Conferência Nacional de Segurança Pública. Brasília: Ministério da Justiça, 2009c.

MIRAGLIA, Paula. Índices de pobreza e o idioma da violência:- pobreza e criminalidade - Debates. In: FERRARI, Florência et al. (Org.). Sexta-feira n. 8 Periferia. São Paulo: 34, 2006.

MISSE, Michel. O Inquérito Policial na cidade do Rio de Janeiro - Resultados Preliminares. In: Coordenação Geral da 1ㄹ. CONSEG (Org.) Reflexões sobre a Investigação Brasileira através do Inquérito Policial. Cadernos Temáticos da Conseg. Brasília: Ministério da Justiça, ano 1, n. 6, 2009.

MORAES, Bismael Batista. Direito e polícia: uma introdução à polícia judiciária. São Paulo: Revista dos Tribunais, 1986.

MUNIZ, Jacqueline de Oliveira. A crise de identidade das polícias militares brasileiras: dilemas e paradoxos da formação educacional. Security and Defense Studies Review, v. 1, p. 187-198, 2001.

; ZACCHI, José Marcelo. Avanços, frustrações e desafios para uma política progressista, democrática e efetiva de segurança pública no Brasil. In: ESCOBAR, S. et al. Seguridad Ciudadana: concepciones y políticas. Caracas: Nueva Sociedad, 2005.

NÚCLEO DE ESTUDOS DA VIOLÊNCIA. Taxa Geral de Homicídio (/100 mil hab.) por Regiões e Estados (2000 - 2006). In: Núcleo de Estudos da Violência Universidade de São Paulo. Disponível 
em:<http://nevusp.org/downloads/bancodedados/Homic\%eddios/Estados/TAXA\%20 GERAL\%20DE\%20HOMICIDIOS\%20POR\%20REGIOES\%20E\%20ESTADOS\%20 \%282000)2006\%29.htm>.

OBINGER, Herbert; LEIBFRIED, Stephan; CASTLES, Francis. Federalism and the Welfare State: New World and European Experiences. Cambridge: Cambridge University Press, 2005.

O'DONNELL, Guilhermo. Poliarquias e a (in)efetividade da lei na América Latina: uma conclusão parcial. In: MENDEZ, J.; O'DONNELL, G.; PINHEIRO, P. S. (Org.). Democracia, violência e injustiça: o não-estado de direito na América Latina. São Paulo: Paz e Terra, 2000.

Human Development, Human Rights, and democracy. In: O'DONNELL,G.; CULLELL, J. V.; IAZZETTA, O. (Org.). The quality of democracy: theory and applications. South Ben: University of Notre Dame Press, 2004.

. Why the Rule of Law Matters. Journal of Democracy, Washington, DC, v. 15, n. 4 , out. 2004.

ORLLOF, Ann Shola. The political origins of America's belated Welfare State. In: WEIR, M.; ORLLOf, Ann Shola; SKOCPOL, Theda (ed.). The politics of social policy in the United States. Princeton: Princeton University Press, 1988.

OUVIDORIA DA POLÍCIA DO ESTADO DE SÃO PAULO. Relatório Anual de Prestação de Contas. São Paulo: Imprensa Oficial, 2000.

PAVEZ, Thais. Políticas públicas e ampliação de capital social em comunidades segregadas: o programa Santo André Mais Igual. Dissertação de mestrado. Departamento de Ciência Política, Faculdade de Filosofia, Letras e Ciência Política: Universidade de São Paulo, 2006.

PERES, Maria Fernanda Tourinho (Org.). Violência por armas de fogo no Brasil. Relatório Nacional. São Paulo: Núcleo de Estudos da Violência/Universidade de São Paulo, 2004.

PIAZZON, Rafael Antonio. A progressão de regime em crime hediondo. In: Universidade do Contestado, s/d. Disponível em: $<$ http://www.cdr.unc.br/cursos/Direito/Rafael.doc>. 
PIERSON, Paul. Fragmented Welfare States: Federal Institutions and the development of Social Policy. Governance: An International Journal of Policy and administration, Austrália, 8 (4), p. 449-478, 1995.

. The New Politics of the Welfare State. World Politics, Princeton, 48(2), p. 143-179, 1996.

Coping with Permanent Austerity: Welfare state Reestructuring in Affluent Democracies. In: PIERSON, Paul (Ed). The New Politics of the Welfare State. Oxford: Oxford University Press, 2001.

. Positive feedback and path dependence. In: PIERSON, Paul. Politics in Time. Princenton: Princenton University Press, 2004.

Public policies as institutions. In: SHAPIRO, lan et al. (Ed). Rethinking Political Institutions. New York: New York University Press, 2006.

PINHEIRO, Paulo Sérgio. Autoritarismo e transição. Revista USP, São Paulo, v. 9, 1991.

. I Relatório Nacional sobre Direitos Humanos no Brasil. São Paulo: USP/ Secretaria de Estado dos Direitos Humanos, 1999.

. O estado de direito e os não-privilegiados na América Latina. In: MENDEZ, Juan; O'DONNELL, Guilhermo; PINHEIRO, Paulo Sergio (Org.). Democracia, violência e injustiça: o não-estado de direito na América Latina. São Paulo: Paz e Terra, 2000.

PUTNAM, Robert. Comunidade e democracia: a experiência da Itália moderna. 5. ed. Rio de Janeiro: FGV, 2007.

RAMOS, Silvia. Direito à segurança: um balanço das respostas brasileiras e uma agenda para o Brasil. Texto para discussão no seminário "Uma agenda para o Brasil: desafios e perspectivas", INESC, Brasília, jun. 2007. Disponível em: $<$ http://www.inesc.org.br/biblioteca/textos-e-manifestos/direito-a-seguranca-umbalanco-das-respostas-brasileiras-e-uma-agenda-para-o-brasil>. 
REZENDE DE CARVALHO, Maria Alice. Cultura política, capital social e a questão do déficit democrático no Brasil. In: VIANNA, L. W. (Org.). A democracia e os três poderes no Brasil. Belo Horizonte: UFMG; Rio de Janeiro: IUPERJ/FAPERJ, 2002.

RIBEIRO, Ludmila Mendonça Lopes; CRUZ, Marcus Vinicius Gonçalves da; BATITUCCI, Eduardo Cerqueira. Descentralização da segurança pública: dilemas na governança, $2003 . \quad$ Disponível em: <http://www.anpad.org.br/enanpad/2003/dwn/enanpad2003-gpg-0100.pdf>.

ROCHA, Fernando Carlos Wanderley. Situação das PECs que tramitam na Câmara dos Deputados, tratando do emprego das Guardas Municipais em atividades de segurança pública. Consultoria Legislativa da Câmara dos Deputados, 2005. In: Observatório de Segurança Pública. Disponível em: <http://www.observatoriodeseguranca.org/files/2005_5944.pdf>.

SADER, Eder. Quando novos personagens entraram em cena. Experiências e lutas dos trabalhadores da Grande São Paulo. 1970-1980. São Paulo: Paz e Terra, 1988.

SAINT-PIERRE, Héctor Luis; WINAND, Érica. O legado da transição na agenda democrática para a defesa: os casos brasileiro e argentino. In: SAINT-PIERRE, Héctor Luis (Org.). Controle civil sobre os militares e política de defesa na Argentina, no Brasil, no Chile e no Uruguai. São Paulo: UNESP, 2007.

SCHNEIDER, Mark; SCHOLZ, John; LUBELL, Mark; MINDRUTA, Denisa e EDWARSEN, Matthew. Building consensual institutions: networks and the National Estuary Program. American Journal of Political Science, 47 (1), 2003.

SCKOPOL, Theda. Bringing the state back in: strategies of analysis in current research. In: EVANS, Rueschemeyer and SCKOPOL, Theda (Ed.). Bringing the State Back In. Cambridge: Cambridge University Press, 1985.

SENTO-SÉ, João Trajano Prevenção da violência: o papel das cidades. Rio de Janeiro: Civilização Brasileira, 2005.

SETTE CÂMARA, Paulo Celso Pinheiro. Integração alternativa para segurança pública. In: Seminário Internacional de Segurança Pública, II Fórum Nacional de Direitos Humanos e Segurança Pública na Amazônia e Encontro de Ouvidores. Belém: Secretaria Executiva de Segurança Pública do Pará, 1999. 
SHAW, Margaret. El papel del gobierno local en la seguridad de las comunidades. Centro Internacional para la Prevención de la Criminalidad, s/d. Disponível em: $<w w w . c r i m e-p r e v e n t i o n-i n t l . o r g / p u b l i c a t i o n s / p u b \_72 \_1 . p d f>$.

SILVA, Jorge da. Violência policial e ideologia dos algozes-vítimas. In: OLIVEIRA, Dijaci David et al. (Org.). Violência policial: tolerância zero?. Goiânia: UFG, 2001.

SILVA FILHO, José Vicente da. Guarda Municipal para que?. Jornal da Tarde, São Paulo, 6 jul. 2000.

SIMAP/PRONASCI. Pronasci em números. Janeiro de 2009. Ministério da Justiça/Pronasci e FGV Projetos, 2009. Disponível em: $<$ http://www.fgv.br/fgvprojetos/arq/88.pdf>.

SLAKMON, Catherine; OXHORN, Philip. O poder de atuação dos cidadãos e a microgovernança da justiça no Brasil. In: Novas direções na governança da justiça e da segurança. Brasília: Ministério da Justiça, 2006.

SOARES, Luiz Eduardo. Meu casaco de general: quinhentos dias no front da segurança pública do Rio de Janeiro. São Paulo: Companhia das Letras, 2000.

Novas políticas de Segurança Pública: alguns exemplos recentes. In: Jus Navegandi, $2002 . \quad$ Disponível em: $<$ http://jus2.uol.com.br/doutrina/texto.asp?id=4096>.

A política nacional de segurança pública: histórico, dilemas e perspectivas. Estudos Avançados - Dossiê Crime Organizado, São Paulo, v. 21, n. 61, p. 77- 97, 2007.

ROLIM, Marcos e RAMOS, Silvia. O que pensam os profissionais da segurança pública, no Brasil. Brasília, Ministério da Justiça/SENASP, 2009. In: Segurança Pública. Disponível em: <http://www.mj.gov.br/data/Pages/MJCF2BAE97ITEMID265C344CCF4B48B68EDC 906D15067F01PTBRIE.htm>.

SOUZA, Celina. Federalismo e descentralização na Constituição de 1988: processo decisório, conflitos e alianças. Dados - Revista de Ciências Sociais, Rio de Janeiro, v. 44, n. 3, p. 513-560, 2001. 
. Federalismo, desenho constitucional e instituições federativas no Brasil pós1988. Revista de Sociologia e Política, Curitiba, n. 24, p. 105-121, jun. 2005.

. Estado da arte da pesquisa em políticas públicas. In: HOCHMAN, Gilberto; ARRETCHE, Marta; MARQUES, Eduardo (Org.). Políticas públicas no Brasil. Rio de Janeiro: Fiocruz, 2007.

SOUZA, Fátima. Como funciona a polícia militar. In: How stuff works? Como tudo funciona, s/d. Disponível em: <http://pessoas.hsw.uol.com.br/policiamilitar.htm/printable>.

STEPAN, Alfred. Rethinking Military Politics. Princeton: Princeton University Press, 1988.

TREVAS, Vicente Carlos y Plá; CÂMARA PINTO, Bruno Benfica; CUNHA, Mariana; CUNHA, Roseni Evangelista. O governo Lula e a estratégia de fortalecimento da federação: o caso do Comitê de Articulação Federativa. In: IX Congresso Internacional del CLAD sobre la reforma del Estado y de la Administración Pública, Madrid, Espanha, nov. 2004.

UN-HABITAT. Un enfoque democrático em matéria de seguridad urbana. Programa Cidades mais Seguras. Documento conceitual, s/d. (mimeo)

VANDERSCHUEREN, Franz. Desafios de la seguridad ciudadana Revista Persona y Sociedad, Chile, Universidad Alberto Hurtado, v. XIX, n. 1, abr. 2005.

; MARCUS, Michel. Políticas de Seguridad Ciudadana en Europa y América Latina. Leciones y desafios. Chile: División de Seguridad Ciudadana, Ministério del Interior, 2004.

VARGAS, Joana D.; NASCIMENTO, Luís Felipe. O inquérito policial no Brasil: uma pesquisa empírica - O caso da investigação criminal de homicídios dolosos em Belo Horizonte. In: Coordenação Geral da 1a. CONSEG (Org.) Reflexões sobre a Investigação Brasileira através do Inquérito Policial. Cadernos Temáticos da Conseg. Brasília, Ministério da Justiça, ano 1, n. 6, 2009.

WACQUANT, Loïc. A ascensão do Estado penal nos EUA. Discursos Sediciosos, Rio de Janeiro, ano 7, n. 11, $1^{\circ}$ semestre 1998. 
. Qual zero? Qual tolerância? Correio Braziliense, Brasília, 30 jun. 2002.

WAISELFISZ, Júlio Jacobo. Mapa da violência 2006. Os jovens do Brasil. Brasília: Organização dos Estados Ibero-americanos-OEl, 2006.

WEBER, Max. Ciência e política: duas vocações. São Paulo: Cultrix, 2000.

WIERVIOKA, Michel. O novo paradigma da violência. Tempo Social. São Paulo, 9 (1): 5-41, mai. 1997.

WOOD, Jennifer; MARKS, Monique. Governança conexa: desenvolvendo novas ideias para a segurança e a justiça. In: SLAKMON, C. et al. (Org.). Novas direções na governança da justiça e da segurança. Brasília: Ministério da Justiça/Secretaria da Reforma do Judiciário, 2006.

ZALUAR, Alba. Exclusão e políticas públicas: dilemas teóricos e alternativas políticas. In: ZALUAR, Alba. Integração perversa: pobreza e tráfico de drogas. Rio de Janeiro: FGV, 2004.

ZAVERUCHA, Jorge. A Constituição Brasileira de 1988 e seu legado autoritário: formalizando a democracia, mas retirando a sua essência. In: ZAVERUCHA, Jorge (Org.). Democracia e instituições políticas brasileiras no final do século XX. Recife: Bagaço, 1998.

Constituição, polícia militar e forças armadas: que democracia é esta? In: BENEDITO, Mariano; FREITAS, Isabel (Org.). Polícia: desafio da democracia brasileira. Porto Alegre: Corag, 2002.

. (Des)Controle civil sobre os militares no governo Fernando Henrique Cardoso. Lusotopie, Paris, n. 12, v. 3, p. 399-418, 2003.

. Polícia civil de Pernambuco: o desafio da reforma. Recife: UFPE, 2004.

; MELO FILHO, Hugo Cavalcanti. Superior Tribunal Militar: entre o autoritarismo e a democracia. Dados - Revista de Ciências Sociais, Rio de Janeiro, v. 47, p. $763-797,2004$. 
Segundo consta dos anais da 1ª . CONSEG, os segmentos representados na CON observaram os seguintes critérios:

Sociedade civil - Prioridade para as redes e/ou organizações e movimentos com considerável capilaridade e potencial de articulação, com reconhecido acúmulo de discussão específica sobre segurança pública;

Trabalhadores da área de segurança pública - Maior diversidade possível de associações com legitimidade nacional, bem como das categorias internas da corporação de cada uma das cadeiras previstas na CON;

Gestores - Participação expressiva dos agentes políticos das três esferas da federação (União, Estados e municípios) que exercem responsabilidades de gestão pública em órgãos do executivo envolvidos diretamente na área de segurança pública;

Demais poderes - Representantes dos poderes Legislativo, Judiciário e Ministério Público.

\section{DISTRIBUIÇÃO DAS CADEIRAS POR SEGMENTO}

Obs.: Destacam-se, em negrito, os atores que responderam ao questionário, para esta dissertação:

\section{SOCIEDADE CIVIL}

1. Fórum Brasileiro de Segurança Pública

2. Rede Desarma Brasil

3. Rede F4

4. Ordem dos Advogados do Brasil (OAB)

5. Movimento Nacional de Direitos Humanos (MNDH)

6. Fórum de Entidades Nacionais de Direitos Humanos (FENDH)

7. Viva Rio

8. Instituto Sou da Paz 
9. Instituto São Paulo Contra a Violência (Fórum da Cidadania Contra a Violência de São Paulo e Fórum Metropolitano de Segurança Pública)

10. Conselho Nacional de Igrejas Cristãs do Brasil (CONIC)

11. Rede Nacional de Altos Estudos em Segurança Pública (RENAESP)

12. Grande Oriente do Brasil

13. Conselho Nacional de Política Criminal e Penitenciária (CNPCP)

\section{TRABALHADORES}

14. Associações Nacionais da Polícia Federal:

- Associação Nacional dos Delegados de Polícia Federal (ADPF)

- Associação Nacional dos Peritos Criminais Federais (APCF)

- Federação Nacional dos Policiais Federais (FENAPEF)

15. Federação Nacional dos Policiais Rodoviários Federais (FENAPRF) 16. Associações Nacionais da Polícia Militar:

- Associação Nacional dos Oficiais Militares Estaduais (AMEBRASIL)

- Associação Nacional de Entidades Representativas de Praças Policiais e Bombeiros (ANASPRA)

- Federação Nacional de Entidades de Oficiais Militares Estaduais (FENEME)

Associações Nacionais da Polícia Civil:

- Associação dos Delegados de Polícia do Brasil (ADEPOL)

- Confederação Brasileira de Trabalhadores Policiais Civis (COBRAPOL)

17. Associações Nacionais da Polícia Técnico-Científica:

- Associação Brasileira de Criminalística (ABC)

- Associação Brasileira dos Médicos Legistas Civis (ABML)

- Federação Nacional dos Papilocopistas Policiais (FENAPPI)

18. Liga Nacional de Corpos de Bombeiros Militares do Brasil (LIGABOM)

19. Conselho Nacional das Guardas Municipais

20. Sindicato dos Agentes Penitenciários Federais (SINDAPEF)

21. Fórum Nacional de Ouvidores de Polícia

22. Associação Nacional dos Defensores Públicos (ANADEP) 


\section{GESTORES}

23. Ministério da Justiça - Coordenação Executiva

24. Ministério da Justiça - Departamento de Polícia Federal

25. Ministério da Justiça - Departamento de Polícia Rodoviária Federal

26. Secretaria Geral da Presidência da República (SEGES) / Secretaria Especial de Direitos Humanos (SEDH)

\section{Colégio Nacional dos Secretários de Segurança Pública}

28. Conselho Nacional de Comandantes Gerais das Polícias Militares e dos Corpos de Bombeiros Militares

29. Conselho Nacional de Chefes da Polícia Civil

30. Conselho Nacional dos Secretários de Estado da Justiça, Cidadania, Direitos Humanos e Administração Penitenciária

31. Conselho de Dirigentes dos Órgãos Periciais do Brasil

32. Frente Nacional de Prefeitos

33. Gabinetes de Gestão Integrada Municipal

\section{DEMAIS PODERES}

34. Conselho Nacional de Justiça

35. Conselho Nacional dos Procuradores-Gerais do Ministério Público dos Estados e da União

36. Conselho Nacional do Ministério Público/Conselho Nacional dos Procuradores-Gerais do Ministério Público dos Estados e da União 


\section{ANEXO B - Matriz do questionário \\ DEPARTAMENTO DE CIÊNCIA POLÍTICA - USP \\ PESQUISA DE MESTRADO}

INSTITUIÇÃO:

NOME:

CONTATOS:

1. Qual é a agenda de propostas de sua instituição para a segurança pública?

2. Para sua instituição, para se obter um provimento mais efetivo e adequado de segurança pública, reformas constitucionais no que se refere à política de segurança pública e às instituições policiais são:

( ) essenciais

( ) importantes

( ) indesejáveis

( ) indiferentes

3. Para sua instituição, os municípios devem ter alguma atribuição específica dentro do sistema de segurança pública?

( ) sim ( ) não Se sim, qual:

4. Para a sua instituição, a participação social na política de segurança pública é:

Muito importante ( )

Relativamente importante ( )

Indesejável ( )

Indiferente ( )

5. Há alguma(s) medida(s) gerencial(ais) ou de gestão que sua instituição considera relevante para maior eficiência das instituições de segurança pública? Quais? 
6. Há alguma proposta de mudança constitucional no modelo do sistema de segurança pública que sua instituição tenha proposto ou defenda?

a. Unificação das polícias civil e militar.

( ) $\operatorname{sim}$ ( ) não

b. Desvinculação da polícia militar como força auxiliar e reserva do Exército.

( ) $\operatorname{sim}$ ( ) não

c. Desconstitucionalização do artigo 144 , da CF, para que cada estado da federação possa escolher a polícia que deseja.

( ) $\operatorname{sim}$ ( ) não

d. Ampliação das atribuições das guardas municipais.

( ) $\operatorname{sim}$ ( ) não

Se sim, para que tenham quais atribuições?

e. Atribuição de ciclo completo da atividade policial a todas as instituições policiais.

( ) $\operatorname{sim}($ ) não

f. Outra:

7. Para sua instituição, o atual modelo de segurança pública:

( ) não precisa ser alterado.

( ) não precisa ser alterado, mas é preciso investir mais em recursos materiais e humanos.

( ) não precisa ser alterado, mas é preciso modernizar a gestão.

( ) precisa ser alterado para incluir novos atores, como os municípios, fortalecendose a prevenção, com maior participação social na implementação e controle das políticas públicas de segurança.

( ) precisa ser estruturalmente reformulado, inclusive com a criação de um novo modelo de instituições policiais. 


\section{ANEXO C - Sistematização das respostas ao questionário}

\section{Quadro 1}

Agenda de propostas para a segurança pública

\begin{tabular}{|c|c|c|}
\hline & ATORES & PROPOSTAS \\
\hline \multirow{3}{*}{ 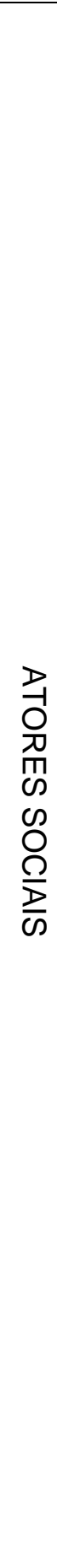 } & $\begin{array}{c}\text { FÓRUM DE } \\
\text { ENTIDADES } \\
\text { NACIONAIS DE } \\
\text { DIREITOS } \\
\text { HUMANOS }\end{array}$ & $\begin{array}{l}\text { Efetiva implementação da Lei Maria da Penha; } \\
\text { Fim do extermínio da juventude negra; } \\
\text { Combate à intolerância religiosa, às religiões de matrizes } \\
\text { africanas; } \\
\text { Desmilitarização das Polícias Militares; } \\
\text { Respeito à diversidade (LGBT); } \\
\text { Respeito aos movimentos sociais. }\end{array}$ \\
\hline & $\begin{array}{c}\text { INSTITUTO } \\
\text { SÃO PAULO } \\
\text { CONTRA A } \\
\text { VIOLÊNCIA }\end{array}$ & $\begin{array}{l}\text { Evitar ações de terrorismo urbano; } \\
\text { Enfraquecer o crime organizado dentro e fora das } \\
\text { prisões; } \\
\text { Reduzir crimes e violências com grande repercussão na } \\
\text { mídia (rebeliões, sequestros, arrastões); } \\
\text { Intensificar o policiamento ostensivo, investigação } \\
\text { criminal em áreas com presença do crime organizado e } \\
\text { maior risco de violências; } \\
\text { Prisão de lideranças do crime organizado e de autores } \\
\text { de ações de terrorismo e de crimes que resultem em } \\
\text { morte; } \\
\text { Promover a segurança do cidadão, com participação } \\
\text { social no desenvolvimento das políticas. }\end{array}$ \\
\hline & $\begin{array}{c}\text { FÓRUM } \\
\text { BRASILEIRO } \\
\text { DE } \\
\text { SEGURANÇA } \\
\text { PÚBLICA }\end{array}$ & $\begin{array}{l}\text { Promoção da paz, da cidadania e dos direitos humanos; } \\
\text { Intercâmbio e difusão de ideias e conhecimentos para o } \\
\text { aperfeiçoamento da organização policial, das práticas } \\
\text { policiais e dos serviços de segurança pública; } \\
\text { Primado dos direitos humanos, em particular das } \\
\text { garantias plenas da integridade física e do devido } \\
\text { processo legal; } \\
\text { Transparência, participação e controle social; } \\
\text { Proatividade e ênfase preventiva como estratégias } \\
\text { primordiais; } \\
\text { Coprodução, multissetorialidade, integração } \\
\text { interinstitucional (polícias, justiça penal, órgãos públicos } \\
\text { sociais e urbanos, universidades, sociedade civil); } \\
\text { Eficiência, efetividade e eficácia na redução de índices } \\
\text { de criminalidade, violência e insegurança; } \\
\text { Qualidade na prestação de serviços policiais e de } \\
\text { segurança pública, especialmente no atendimento das } \\
\text { vitimas da violência; } \\
\text { Valorização do policial como profissional e servidor } \\
\text { público. }\end{array}$ \\
\hline
\end{tabular}




\begin{tabular}{|c|c|c|}
\hline & $\begin{array}{l}\text { INSTITUTO } \\
\text { SOU DA PAZ }\end{array}$ & $\begin{array}{l}\text { Segurança pública como direito social a ser garantido a } \\
\text { todas as pessoas para que tenham liberdade e } \\
\text { convivência pacífica; } \\
\text { Segurança pública provida em todas as esferas de } \\
\text { governo, de forma integrada e com participação social; } \\
\text { Aliar prevenção e repressão qualificada; } \\
\text { Atuar em cinco áreas: controle de armas; juventude e } \\
\text { prevenção da violência; gestão local de segurança; } \\
\text { polícia; e cultura e valores. }\end{array}$ \\
\hline & VIVA RIO & $\begin{array}{l}\text { Atuar em três grandes eixos: juventude, polícias e } \\
\text { armas, com desenvolvimento de projetos no Brasil e no } \\
\text { Exterior; } \\
\text { Foco nos temas sobre drogas; segurança municipal, } \\
\text { formação de guardas e polícias, operações de paz e } \\
\text { juventude envolvida com o crime. }\end{array}$ \\
\hline & $\begin{array}{l}\text { REDE } \\
\text { DESARMA } \\
\text { BRASIL }\end{array}$ & $\begin{array}{l}\text { Controle de armas; } \\
\text { Planos de segurança pública municipais; } \\
\text { Implementação do Estatuto do Desarmamento. }\end{array}$ \\
\hline & $\begin{array}{l}\text { REDE F4** } \\
\text { (Observatório } \\
\text { de Favelas) }\end{array}$ & $\begin{array}{l}\text { Valorização da vida como princípio fundamental das } \\
\text { políticas de segurança pública; } \\
\text { Ampliação e fortalecimento dos canais de participação } \\
\text { social reconhecendo os espaços populares como partes } \\
\text { integrantes da cidade; } \\
\text { Fortalecimento dos mecanismos de controle externo da } \\
\text { atividade policial; } \\
\text { Reformas estruturais no modelo de polícia; } \\
\text { Desmilitarização; } \\
\text { Investimento em ações voltadas para a redução da } \\
\text { letalidade da ação policial; } \\
\text { Fortalecer a implementação de uma política de } \\
\text { desarmamento; } \\
\text { Criação de uma política nacional com foco na redução } \\
\text { de homicídios de adolescentes e jovens. }\end{array}$ \\
\hline & $\begin{array}{l}\text { GRANDE } \\
\text { ORIENTE DO } \\
\text { BRASIL }\end{array}$ & $\begin{array}{l}\text { Trabalhar com a juventude na prevenção e rejeição das } \\
\text { drogas; } \\
\text { Trabalhar a cultura de paz nas escolas; } \\
\text { Trabalhar a campanha do desarmamento - controle } \\
\text { sobre as armas e munições. }\end{array}$ \\
\hline & RENAESP & $\begin{array}{l}\text { Qualificação para todos os níveis hierárquicos das } \\
\text { corporações policiais; } \\
\text { Formação qualificada na graduação, mestrado e } \\
\text { doutorado; } \\
\text { Ações de prevenção da violência, justiça e direitos } \\
\text { humanos. }\end{array}$ \\
\hline 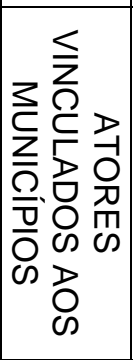 & $\begin{array}{c}\text { FRENTE } \\
\text { NACIONAL DE } \\
\text { PREFEITOS }\end{array}$ & $\begin{array}{l}\text { Articulação federativa, assegurando-se a participação } \\
\text { social na construção da política de segurança pública; } \\
\text { Consolidação do Pronasci como política de Estado; } \\
\text { Rearticulação do CONASP, conselhos estaduais e } \\
\text { municipais, garantindo a participação de gestores, } \\
\text { trabalhadores e da sociedade civil; } \\
\text { Implementação de políticas públicas de prevenção, } \\
\text { fortalecendo o papel dos municípios. }\end{array}$ \\
\hline
\end{tabular}




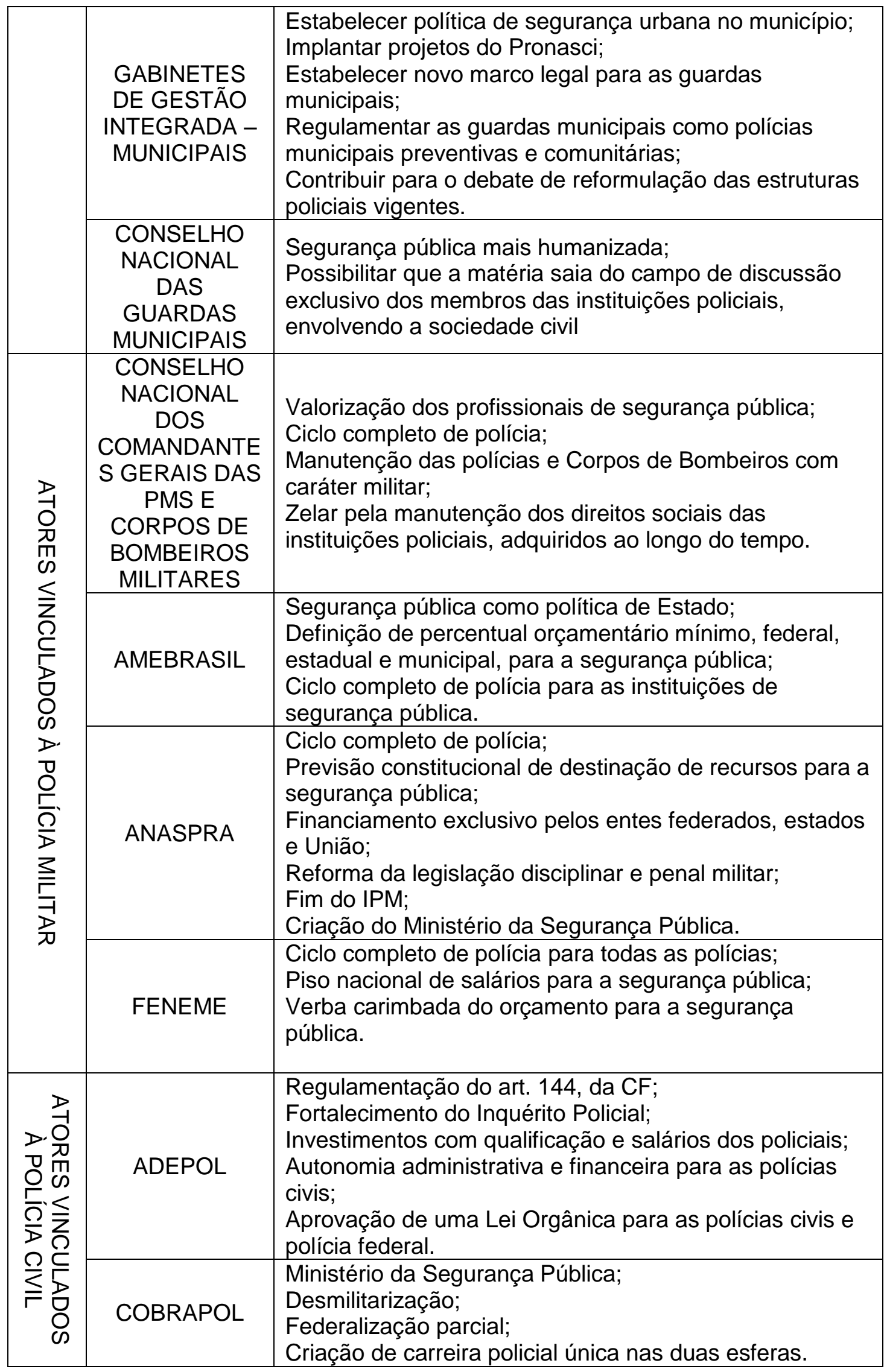




\begin{tabular}{|c|c|c|}
\hline 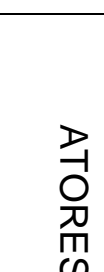 & FENAPRF & $\begin{array}{l}\text { Valorização do policial; } \\
\text { Aumento do efetivo; } \\
\text { Combate à exploração sexual infanto-juvenil; } \\
\text { Preservação do meio-ambiente; } \\
\text { Respeito aos direitos humanos; } \\
\text { Combate efetivo à criminalidade. }\end{array}$ \\
\hline 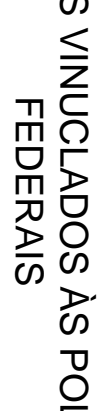 & ADPF & $\begin{array}{l}\text { Autonomia funcional e administrativa das instituições } \\
\text { policiais; } \\
\text { Lei orgânica com um regime de prerrogativas funcionais } \\
\text { que assegurem a independência investigativa; } \\
\text { Resgate constitucional dos delegados de polícia como } \\
\text { carreira jurídica e típica do Estado; } \\
\text { Política de Valorização do sistema de segurança pública } \\
\text { no tocante aos direitos e benefícios na área de recursos } \\
\text { humanos. }\end{array}$ \\
\hline$\frac{\bar{\rho}}{\bar{D}}$ & FENAPEF & $\begin{array}{l}\text { Cargo único; } \\
\text { Extinção do Inquérito Policial; } \\
\text { Fim do Indiciamento na esfera policial; } \\
\text { Democratização no Departamento da Polícia Federal; } \\
\text { Polícia da sociedade e não de governo. }\end{array}$ \\
\hline \multirow{4}{*}{ 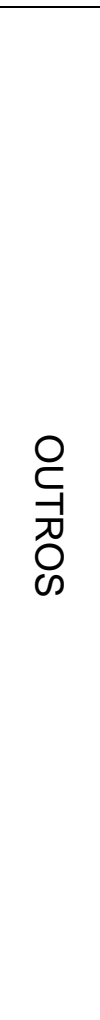 } & $\begin{array}{l}\text { FÓRUM } \\
\text { NACIONAL DE } \\
\text { OUVIDORES } \\
\text { DE POLÍCIA }\end{array}$ & $\begin{array}{l}\text { Sistema Único de Segurança; } \\
\text { Criação de Ouvidoria das Polícias Federais; } \\
\text { Criação de Ouvidorias de Polícia em todos os Estados; } \\
\text { Autonomia das Ouvidorias e indicação dos ouvidores } \\
\text { pela sociedade civil; } \\
\text { Integração das Ouvidorias ao SUSP. }\end{array}$ \\
\hline & $\begin{array}{l}\text { SECRETÁRIO } \\
\text { DE } \\
\text { SEGURANÇA } \\
\text { PÚBLICA DO } \\
\text { AMAZONAS*** } \\
\text { (CONSESP) }\end{array}$ & $\begin{array}{l}\text { Percentual fixo para aplicação na segurança pública } \\
\text { (verba carimbada); } \\
\text { Fortalecimento das ouvidorias, corregedorias, } \\
\text { instituições de ensino e inteligência policial. }\end{array}$ \\
\hline & $A B C$ & $\begin{array}{l}\text { Autonomia da perícia oficial criminal; } \\
\text { Respeito à cidadania e aos direitos humanos; } \\
\text { Valorização dos profissionais da área de segurança; } \\
\text { Transversalidade da segurança pública; } \\
\text { Mudanças na legislação, buscando o fortalecimento das } \\
\text { instituições. }\end{array}$ \\
\hline & SINDAPEF & $\begin{array}{l}\text { Aprovação da PEC 308/2004 que cria a Polícia Penal, no } \\
\text { âmbito das unidades federais e estaduais; } \\
\text { Valorização do servidor da área da segurança; } \\
\text { Reestruturação do sistema penitenciário; } \\
\text { Criação de um sistema penal único. }\end{array}$ \\
\hline
\end{tabular}

* Transcrição da pergunta do questionário: "Qual é a agenda de propostas de sua instituição para a segurança pública?".

** A pessoa que respondeu ao questionário assinalou que o fez representando o Observatório de Favelas, que compõe a Rede F4.

*** O secretário de segurança pública do Amazonas, representante na CON do Conselho Nacional de Secretários Estaduais de Segurança Pública - CONSESP, manifestou verbalmente que as opiniões expressas em todo o questionário eram pessoais, uma vez que não poderia falar pelo Conselho sem consultá-lo previamente. 


\section{Quadro 2}

Sobre a importância das reformas constitucionais na política de segurança pública*

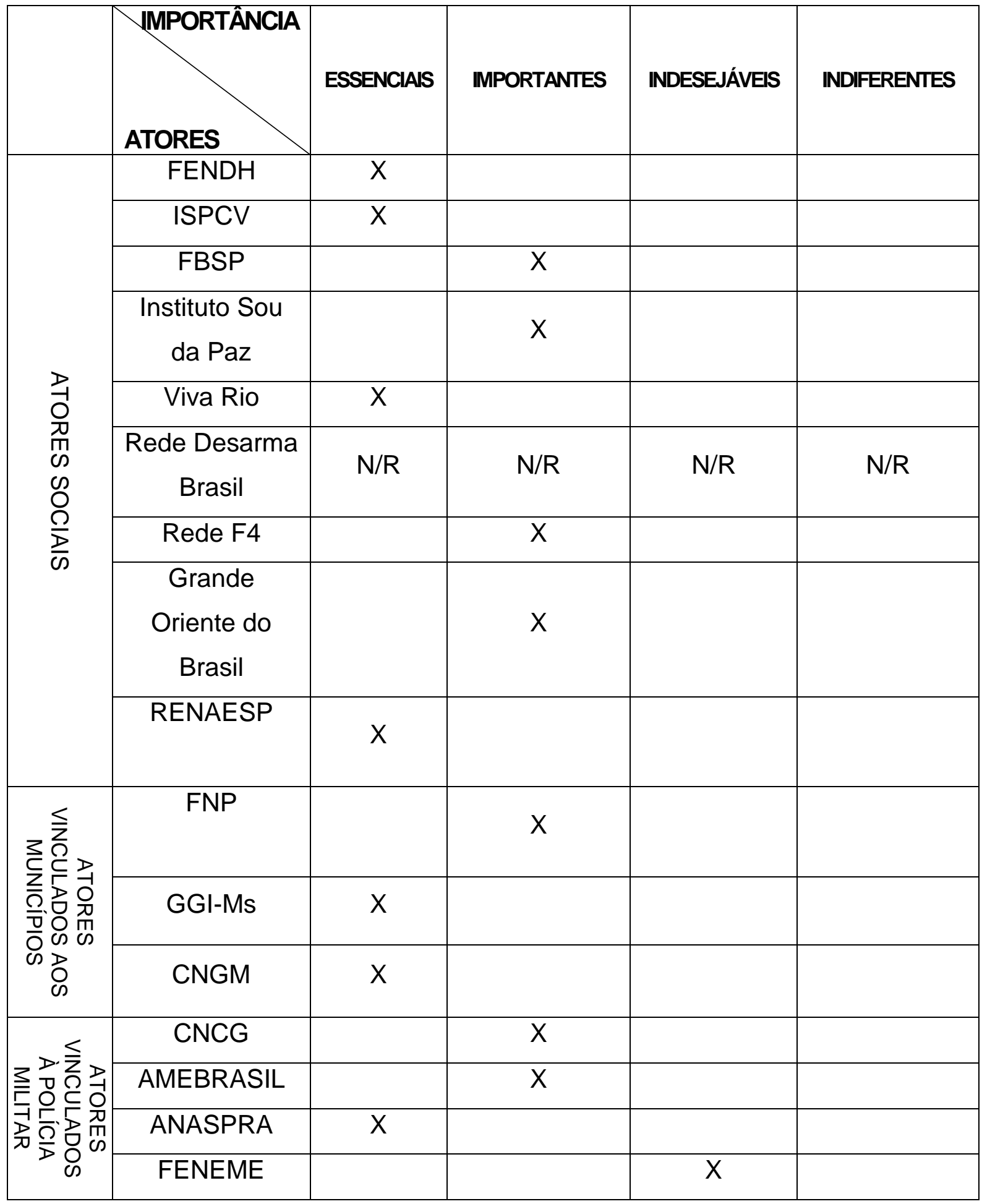




\begin{tabular}{|c|c|c|c|c|c|}
\hline \multirow{2}{*}{ 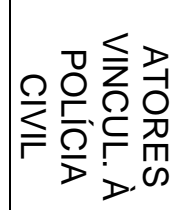 } & ADEPOL & & & $\mathrm{x}$ & \\
\hline & COBRAPOL & $x$ & & & \\
\hline \multirow{3}{*}{ 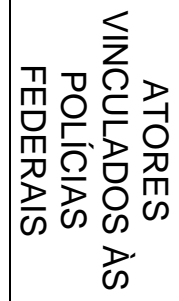 } & FENAPRF & $X$ & & & \\
\hline & ADPF & & & & $X$ \\
\hline & FENAPEF & $\mathrm{X}$ & & & \\
\hline \multirow{4}{*}{ 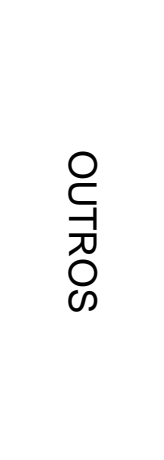 } & FNOP & $X$ & & & \\
\hline & $\begin{array}{c}\text { SSP - } \\
\text { Amazonas } \\
\text { (CONSESP) }\end{array}$ & & $x$ & & \\
\hline & $A B C$ & $\mathrm{X}$ & & & \\
\hline & SINDAPEF & $X$ & & & \\
\hline
\end{tabular}

* Transcrição da pergunta do questionário: "Para sua instituição, para se obter um provimento mais efetivo e adequado de segurança pública, reformas constitucionais no que se refere à política de segurança pública e às instituições policiais são:" Seguiam-se as alternativas constantes do quadro acima.

Obs.: N/R indica que o ator não respondeu. 


\section{Quadro3}

Sobre qual deve ser a atribuição dos municípios dentro do sistema de segurança pública*

\begin{tabular}{|c|c|c|}
\hline & ATORES & PROPOSTAS \\
\hline \multirow{7}{*}{ 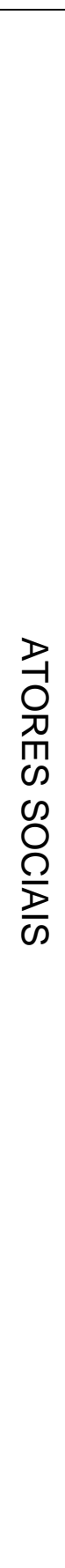 } & FENDH & $\begin{array}{l}\text { Perspectiva da prevenção, iluminação de ruas, } \\
\text { melhoria de logradouros e praças, melhoria da } \\
\text { qualidade de vida dos moradores das comunidades, } \\
\text { por meio de ações preventivas. }\end{array}$ \\
\hline & ISPCV & Prevenção da violência. \\
\hline & FBSP & $\begin{array}{l}\text { O Fórum, pela sua natureza, não pode defender } \\
\text { propostas políticas e sim fortalecer os canais } \\
\text { técnicos de informação passíveis de influenciarem os } \\
\text { responsáveis por ações no campo da segurança } \\
\text { pública. Seja como for, os municípios já participam } \\
\text { do sistema de segurança e devem colaborar no } \\
\text { aumento da sua eficiência democrática. }\end{array}$ \\
\hline & $\begin{array}{l}\text { Instituto Sou } \\
\text { da Paz }\end{array}$ & $\begin{array}{l}\text { Prevenção da violência. } \\
\text { Qualificar políticas de diferentes áreas (saúde, } \\
\text { educação, assistência social), tornando-as políticas } \\
\text { de prevenção da violência. } \\
\text { Investir na gestão municipal da política de segurança } \\
\text { Investir na GCM, para que esta seja comunitária e } \\
\text { preventiva (questão essa que é mais importante que } \\
\text { a questão sobre o poder de polícia para as } \\
\text { Guardas). }\end{array}$ \\
\hline & Viva Rio & $\begin{array}{l}\text { Processo de diagnóstico, elaboração de planos } \\
\text { municipais de ordem pública e formação de } \\
\text { Guardas. }\end{array}$ \\
\hline & $\begin{array}{l}\text { Rede } \\
\text { Desarma } \\
\text { Brasil }\end{array}$ & $\begin{array}{l}\text { Participação efetiva dos governos municipais por } \\
\text { meio do GGI-M e na elaboração e execução com a } \\
\text { sociedade civil dos planos de segurança municipal; } \\
\text { Criação de espaços públicos de diálogo } \\
\text { permanentes para formar estratégias nas localidades } \\
\text { com altos índices de violência social e urbana. }\end{array}$ \\
\hline & Rede F4 & $\begin{array}{l}\text { Foco preventivo e criação de canais que fortaleçam } \\
\text { a participação comunitária. }\end{array}$ \\
\hline
\end{tabular}




\begin{tabular}{|c|c|c|}
\hline & $\begin{array}{c}\text { Grande } \\
\text { Oriente do } \\
\text { Brasil }\end{array}$ & $\begin{array}{l}\text { Contribuir de forma efetiva nas políticas públicas } \\
\text { sociais, saúde, empreendedorismo juvenil, cultura } \\
\text { pela paz nas escolas e comunidades como forma de } \\
\text { preventiva em segurança pública. } \\
\text { Guarda Municipal gerida pelo princípio comunitário e } \\
\text { desarmada (no máximo, uso de armas não letais. }\end{array}$ \\
\hline & RENAESP & $\begin{array}{l}\text { Prevenção com o fortalecimento dos Conselhos } \\
\text { Comunitários de Segurança. }\end{array}$ \\
\hline$>\frac{D}{0}$ & FNP & $\begin{array}{l}\text { Foco prioritário em política pública de prevenção } \\
\text { dirigida para a juventude. }\end{array}$ \\
\hline $\begin{array}{l}0 \\
\infty \\
3 \text { 而 } \\
3\end{array}$ & GGI-Ms & $\begin{array}{l}\text { Município deve ser cogestor da segurança pública, } \\
\text { com foco preventivo. }\end{array}$ \\
\hline 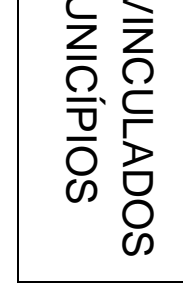 & CNGM & $\begin{array}{l}\text { Devem compor de forma prática e não só filosófica a } \\
\text { questão da segurança pública, porém em um viés } \\
\text { voltado para a prevenção e para um caráter postural, } \\
\text { sem a necessidade de olhar para as práticas das } \\
\text { instituições estaduais. }\end{array}$ \\
\hline $\begin{array}{l}\text { D } \\
\text { O } \\
\text { 盆 } \\
\text { c }\end{array}$ & CNCG & $\begin{array}{l}\text { Composição e responsabilidades conjuntas com os } \\
\text { estados e a União, visto que a Administração } \\
\text { Municipal está mais próxima dos problemas de } \\
\text { segurança pública. }\end{array}$ \\
\hline & AMEBRASIL & $\begin{array}{l}\text { Integrados no sistema de segurança pública, sem } \\
\text { sobreposição com outras instituições. }\end{array}$ \\
\hline 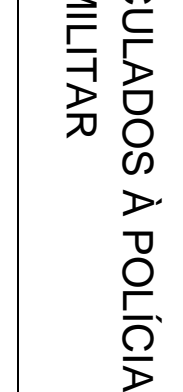 & ANASPRA & $\begin{array}{l}\text { Desenvolver políticas públicas nas áreas de } \\
\text { educação, saúde, habitação, saneamento básico, } \\
\text { como fatores de redução de riscos de violência. } \\
\text { Municípios devem fazer o controle externo e não } \\
\text { deve financiar/pagar o custeio da segurança pública, } \\
\text { pois causa interferência política danosa à segurança } \\
\text { pública. }\end{array}$ \\
\hline & FENEME & Na prevenção, principalmente com recursos. \\
\hline 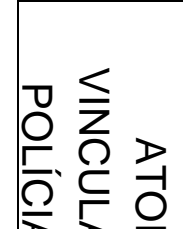 & ADEPOL & $\begin{array}{l}\text { Fortalecimento das Guardas Municipais, para } \\
\text { atuação como importantes atores na prevenção da } \\
\text { ordem pública, por meio de atuação policial } \\
\text { preventiva. }\end{array}$ \\
\hline 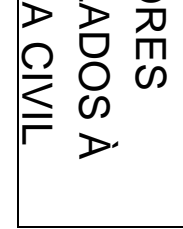 & COBRAPOL & $\begin{array}{l}\text { A ausência do município gera prejuízos à sociedade. } \\
\text { Cidadão reside no município, na comunidade. O } \\
\text { Município é o núcleo básico inicial para o combate à } \\
\text { criminalidade. }\end{array}$ \\
\hline
\end{tabular}




\begin{tabular}{|c|c|c|}
\hline \multirow{3}{*}{ 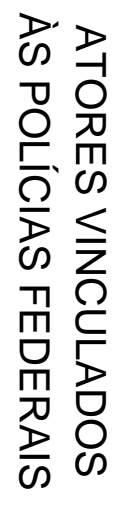 } & FENAPRF & $\begin{array}{l}\text { Pessoas residem nos municípios e o poder público } \\
\text { municipal tem o dever de contribuir de forma efetiva } \\
\text { no sistema de segurança pública. }\end{array}$ \\
\hline & ADPF & $\begin{array}{l}\text { Municípios precisam ter papel fundamental na } \\
\text { segurança, assim como ocorre nas políticas públicas } \\
\text { de educação e saúde. }\end{array}$ \\
\hline & FENAPEF & $\begin{array}{l}\text { É prioritária a polícia comunitária e a intermediação } \\
\text { de conflitos. }\end{array}$ \\
\hline \multirow{4}{*}{$\begin{array}{l}\text { O } \\
\stackrel{1}{1} \\
\text { O } \\
\text { C }\end{array}$} & FNOP & $N / R$ \\
\hline & $\begin{array}{l}\text { SSP - } \\
\text { Amazonas } \\
\text { (CONSESP) }\end{array}$ & $\begin{array}{l}\text { Municípios estão mais próximos da realidade do } \\
\text { povo e conhecem melhor a realidade do município. }\end{array}$ \\
\hline & $A B C$ & $\begin{array}{l}\text { Municípios deveriam participar efetivamente do } \\
\text { sistema de segurança pública, principalmente no } \\
\text { ordenamento de ocupação dos espaços nas cidades, } \\
\text { na manutenção dos espaços públicos. }\end{array}$ \\
\hline & SINDAPEF & $\begin{array}{l}\text { Municípios devem integrar a segurança pública, na } \\
\text { via de suas Guardas Municipais. }\end{array}$ \\
\hline
\end{tabular}

* Transcrição da pergunta do questionário: "Para sua instituição, os municípios devem ter alguma atribuição específica dentro do sistema de segurança pública?" Em seguida, apresentavam-se duas opções "sim" ou "não" e "Se sim, qual". Como todos os respondentes assinalaram a alternativa "sim", apresentamos no quadro o que responderam sobre qual deve ser a atribuição.

Obs.: N/R indica que o ator não respondeu. 


\section{Quadro 4}

Sobre a importância da participação social na política de segurança pública*

\begin{tabular}{|c|c|c|c|c|c|}
\hline & YMPORTÂNCIA & $\begin{array}{c}\text { MUITO } \\
\text { IMPORTANTE }\end{array}$ & $\begin{array}{l}\text { RELATIVA/TE } \\
\text { IMPORTANTE }\end{array}$ & INDESEJÁVEL & INDIFERENTE \\
\hline \multirow{9}{*}{ 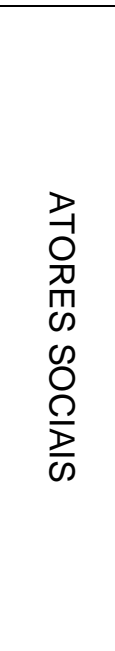 } & $\begin{array}{c}\text { ATORES } \\
\text { FENDH }\end{array}$ & $x$ & & & \\
\hline & ISPCV & $\mathrm{X}$ & & & \\
\hline & FBSP & $\mathrm{X}$ & & & \\
\hline & $\begin{array}{c}\text { Instituto Sou da } \\
\text { Paz }\end{array}$ & $\mathrm{x}$ & & & \\
\hline & Viva Rio & $\mathrm{X}$ & & & \\
\hline & $\begin{array}{c}\text { Rede Desarma } \\
\text { Brasil }\end{array}$ & $\mathrm{x}$ & & & \\
\hline & Rede F4 & $\mathrm{x}$ & & & \\
\hline & $\begin{array}{l}\text { Grande Oriente } \\
\text { do Brasil }\end{array}$ & $x$ & & & \\
\hline & RENAESP & $\mathrm{X}$ & & & \\
\hline \multirow{3}{*}{ 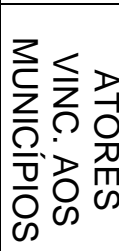 } & FNP & $\mathrm{X}$ & & & \\
\hline & GGI-Ms & $x$ & & & \\
\hline & CNGM & $x$ & & & \\
\hline \multirow{4}{*}{ 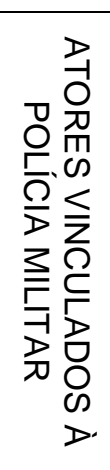 } & CNCG & $x$ & & & \\
\hline & AMEBRASIL & $\mathrm{X}$ & & & \\
\hline & ANASPRA & $x$ & & & \\
\hline & FENEME & & $x$ & & \\
\hline \multirow{2}{*}{ 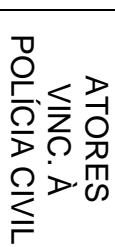 } & ADEPOL & $x$ & & & \\
\hline & COBRAPOL & $\mathrm{X}$ & & & \\
\hline
\end{tabular}




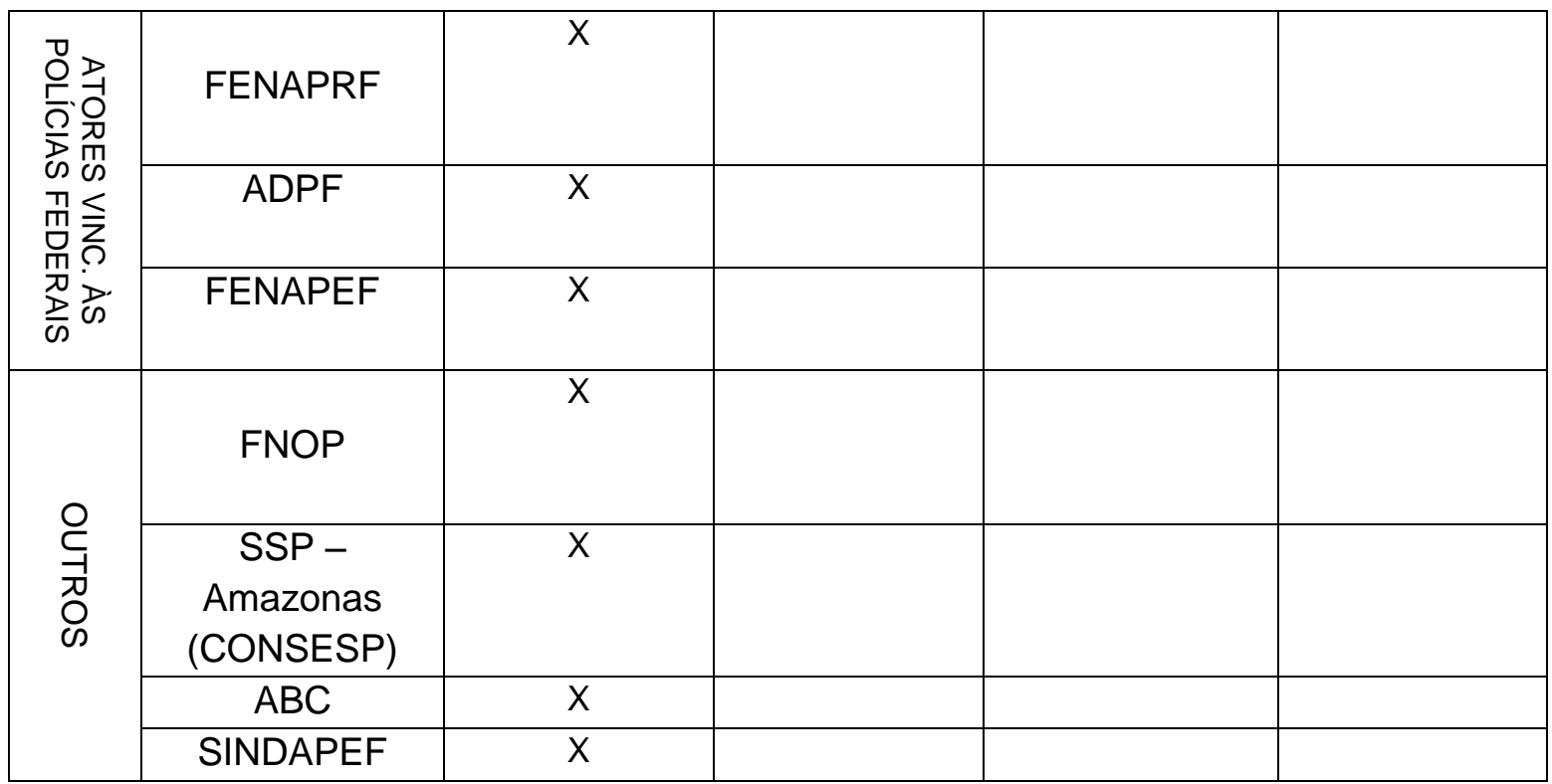

* Transcrição da pergunta do questionário: "Para a sua instituição, a participação social na política de segurança pública é:" Seguiam-se as alternativas constantes do quadro acima. 


\section{Quadro 5}

Sobre reformas gerenciais ou de gestão relevantes para a eficiência das instituições de segurança pública*

\begin{tabular}{|c|c|c|}
\hline & ATORES & PROPOSTAS \\
\hline \multirow{9}{*}{ 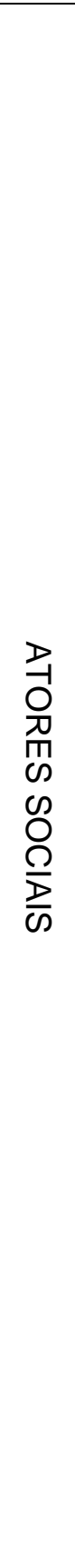 } & FENDH & $\begin{array}{l}\text { Ampliação do processo democrático. } \\
\text { Avanços na interação das instituições de } \\
\text { segurança pública, sociedade civil e governo. }\end{array}$ \\
\hline & ISPCV & $\begin{array}{l}\text { Valorização da carreira policial; } \\
\text { Promoção da integridade da polícia; } \\
\text { Integração das bases de dados das polícias; } \\
\text { Profissionalização da gestão das políticas e } \\
\text { organizações de segurança pública. }\end{array}$ \\
\hline & FBSP & $\begin{array}{l}\text { Adoção de mecanismos de accountability } \\
\text { (transparência, publicidade de dados e } \\
\text { controle social). }\end{array}$ \\
\hline & Instituto Sou da Paz & $\begin{array}{l}\text { Trabalhar com planejamento estratégico; } \\
\text { Integrar os diferentes órgãos de segurança } \\
\text { pública; } \\
\text { Envolver a sociedade civil na gestão. } \\
\end{array}$ \\
\hline & Viva Rio & $\begin{array}{l}\text { Reforma das polícias e planos municipais de } \\
\text { ordem pública. }\end{array}$ \\
\hline & $\begin{array}{l}\text { Rede Desarma } \\
\text { Brasil }\end{array}$ & $\mathrm{N} / \mathrm{R}$ \\
\hline & Rede F4 & $\begin{array}{l}\text { Descentralização aliada à integração } \\
\text { sistêmica; } \\
\text { Ênfase na intersetorialidade; } \\
\text { Consolidação do SUSP. }\end{array}$ \\
\hline & $\begin{array}{l}\text { Grande Oriente do } \\
\text { Brasil }\end{array}$ & $\begin{array}{l}\text { Construção de pontes de diálogo e trabalho } \\
\text { entre a segurança e seus gestores e } \\
\text { trabalhadores com a sociedade civil. }\end{array}$ \\
\hline & RENAESP & $\begin{array}{l}\text { Requalificação da relação da polícia com a } \\
\text { sociedade. }\end{array}$ \\
\hline
\end{tabular}




\begin{tabular}{|c|c|c|}
\hline \multirow{3}{*}{ 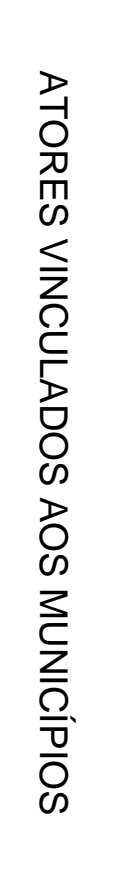 } & FNP & $\begin{array}{l}\text { Investir nos trabalhadores de segurança } \\
\text { pública: formação continuada, condições de } \\
\text { trabalho, apoio e assistência. }\end{array}$ \\
\hline & GGI-Ms & $\begin{array}{l}\text { Interação das agências de segurança; } \\
\text { Abrir o debate sobre o ciclo completo da } \\
\text { atividade policial; } \\
\text { Criar o Ministério da Segurança Pública como } \\
\text { órgão nacional responsável pela Política } \\
\text { Nacional de Segurança Pública; } \\
\text { Rever o Inquérito Policial e desmilitarizar a } \\
\text { polícia ostensiva repressiva. }\end{array}$ \\
\hline & CNGM & $\begin{array}{l}\text { Cumprimento estrito das instituições de } \\
\text { segurança de seus papéis constitucionais, } \\
\text { renegando a disputa de poder; } \\
\text { Rechaço do monopólio que algumas } \\
\text { instituições teimam em defender. }\end{array}$ \\
\hline \multirow{4}{*}{ 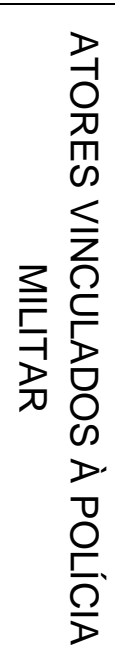 } & CNCG & $\begin{array}{l}\text { O ciclo completo de polícia nos levará a } \\
\text { atender a sociedade de forma mais célere e } \\
\text { efetiva. }\end{array}$ \\
\hline & AMEBRASIL & $\begin{array}{l}\text { Anular a ingerência política, extremamente } \\
\text { danosa às instituições. }\end{array}$ \\
\hline & ANASPRA & $\begin{array}{l}\text { Capacitar as polícias e permitir que tenham o } \\
\text { seu poder de polícia e liberdade para tomar } \\
\text { decisão. }\end{array}$ \\
\hline & FENEME & $\begin{array}{l}\text { Lista tríplice para gestores; } \\
\text { Regulamentação do art. 144, da CF. }\end{array}$ \\
\hline \multirow{2}{*}{ 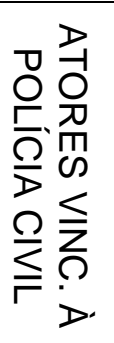 } & ADEPOL & Autonomia administrativa e financeira. \\
\hline & COBRAPOL & $\begin{array}{l}\text { Criação de Conselhos nas três esferas, como } \\
\text { indutores na gestão de programas e políticas } \\
\text { de segurança pública. }\end{array}$ \\
\hline \multirow{3}{*}{ 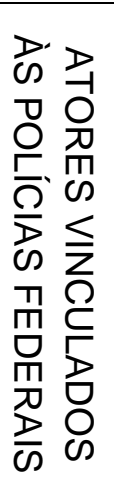 } & FENAPRF & $\begin{array}{l}\text { Capacitação dos policiais para que exerçam } \\
\text { de forma efetiva suas atribuições. }\end{array}$ \\
\hline & ADPF & $\begin{array}{l}\text { Autonomia funcional e administrativa; } \\
\text { Planejamento estratégico; } \\
\text { Indicadores de desempenho. }\end{array}$ \\
\hline & FENAPEF & $\begin{array}{l}\text { Lei Orgânica e a carreira única, bem como a } \\
\text { desburocratização do Inquérito Policial. }\end{array}$ \\
\hline
\end{tabular}




\begin{tabular}{|c|c|l|}
\hline \multirow{4}{*}{$\begin{array}{c}\text { SSP - Amazonas } \\
\text { (CONSESP) }\end{array}$} & $\begin{array}{l}\text { Investimento na formação, inteligência e } \\
\text { instalações. }\end{array}$ \\
\cline { 2 - 3 } & FNOP & $\begin{array}{l}\text { Criação das Ouvidorias de Polícia como } \\
\text { instrumento de participação e controle social } \\
\text { dos órgãos de segurança. }\end{array}$ \\
\cline { 2 - 3 } & ABC & $\begin{array}{l}\text { Investimento na valorização do trabalhador, no } \\
\text { quantitativo adequado, na qualificação } \\
\text { permanente e na assistência integral. }\end{array}$ \\
\cline { 2 - 3 } & SINDAPEF & $\begin{array}{l}\text { Possibilidade de ascensão do servidor ao topo } \\
\text { da carreira. }\end{array}$ \\
\hline
\end{tabular}

* Transcrição da pergunta do questionário: "Há alguma(s) medida(s) gerencial(ais) ou de gestão que sua instituição considera relevante para maior eficiência das instituições de segurança pública? Quais?"

Obs.: N/R indica que o ator não respondeu. 


\section{Quadro 6}

Sobre proposta de mudança constitucional no modelo do sistema de segurança pública

\begin{tabular}{|c|c|c|c|c|c|c|c|}
\hline & ATORES & $\begin{array}{l}\text { Unificação } \\
\text { das polícias }\end{array}$ & $\begin{array}{c}\text { Desvinculação } \\
\text { das PMs do } \\
\text { Exército }\end{array}$ & $\begin{array}{c}\text { Desconstitucio- } \\
\text { nalização do art. } \\
144\end{array}$ & $\begin{array}{c}\text { Ampliação atribuições das } \\
\text { Guardas }\end{array}$ & $\begin{array}{l}\text { Ciclo completo da } \\
\text { atividade policial }\end{array}$ & Outra \\
\hline \multirow{9}{*}{ 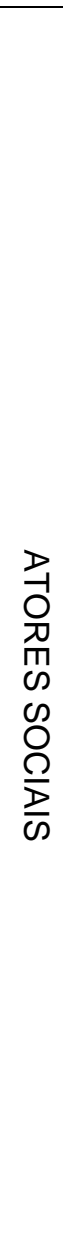 } & FENDH & Sim & Sim & Não & Não & $\begin{array}{l}\text { Sem posicionamento } \\
\text { definido sobre o tema. }\end{array}$ & \\
\hline & ISPCV & $N / R$ & $\mathrm{~N} / \mathrm{R}$ & $\mathrm{N} / \mathrm{R}$ & $N / R$ & $\mathrm{~N} / \mathrm{R}$ & $\begin{array}{c}\text { Propor amplo } \\
\text { debate para } \\
\text { discussão da } \\
\text { questão. } \\
\end{array}$ \\
\hline & FBSP* & $\mathrm{N} / \mathrm{R}$ & $\mathrm{N} / \mathrm{R}$ & $\mathrm{N} / \mathrm{R}$ & $\mathrm{N} / \mathrm{R}$ & $\mathrm{N} / \mathrm{R}$ & \\
\hline & $\begin{array}{l}\text { Instituto Sou } \\
\text { da Paz }\end{array}$ & $N / R$ & Sim & $\mathrm{N} / \mathrm{R}$ & $\begin{array}{l}\text { Não. A discussão deve ser feita de } \\
\text { baixo para cima, a partir das } \\
\text { atividades que as GMs já } \\
\text { desenvolvem na prática e de forma } \\
\text { integrada com as atividades das } \\
\text { outras instituições. }\end{array}$ & $\mathrm{N} / \mathrm{R}$ & \\
\hline & Viva Rio & Não & Sim & Sim & $\begin{array}{l}\text { Sim. Ampliação para atuação em } \\
\text { prevenção. }\end{array}$ & $\begin{array}{c}\text { Ciclo completo necessita } \\
\text { de um maior debate } \\
\text { envolvendo diferentes } \\
\text { atores. }\end{array}$ & \\
\hline & $\begin{array}{l}\text { Rede } \\
\text { Desarma } \\
\text { Brasil }\end{array}$ & $\mathrm{N} / \mathrm{R}$ & Sim & $\mathrm{N} / \mathrm{R}$ & $\mathrm{N} / \mathrm{R}$ & Sim & \\
\hline & Rede F4** & $\mathrm{N} / \mathrm{R}$ & Sim & $\mathrm{N} / \mathrm{R}$ & $\mathrm{N} / \mathrm{R}$ & $\mathrm{N} / \mathrm{R}$ & \\
\hline & $\begin{array}{c}\text { Grande } \\
\text { Oriente do } \\
\text { Brasil }\end{array}$ & Não & Não & Não & $\begin{array}{c}\text { Sim. Para trabalhos } \\
\text { essencialmente comunitários. }\end{array}$ & Sim & \\
\hline & RENAESP & Sim & Sim & “????” & Sim & Sim & \\
\hline
\end{tabular}




\begin{tabular}{|c|c|c|c|c|c|c|c|}
\hline & ATORES & $\begin{array}{l}\text { Unificação } \\
\text { das polícias }\end{array}$ & $\begin{array}{l}\text { Desvinculação } \\
\text { das PMs do } \\
\text { Exército }\end{array}$ & $\begin{array}{l}\text { Desconstitucio- } \\
\text { nalização do art. } \\
144\end{array}$ & $\begin{array}{c}\text { Ampliação atribuições das } \\
\text { Guardas }\end{array}$ & $\begin{array}{l}\text { Ciclo completo da } \\
\text { atividade policial }\end{array}$ & Outra \\
\hline \multirow{3}{*}{ 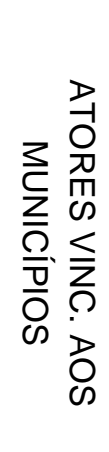 } & $\mathrm{FNP}^{* * *}$ & Sim & Sim & Não & Sim & Sim & \\
\hline & GGI-Ms & $N / R$ & Sim & Sim & $\begin{array}{l}\text { Sim. Polícia Municipal } \\
\text { preventiva e comunitária. }\end{array}$ & Sim & $\begin{array}{l}\text { Tornar o } \\
\text { SUSP um } \\
\text { sistema } \\
\text { constitucional. }\end{array}$ \\
\hline & CNGM & Não & Sim & Não & Sim & Não & \\
\hline \multirow{4}{*}{ 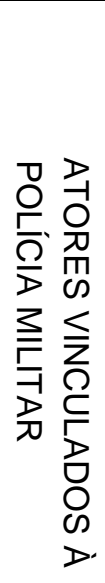 } & CNCG & Não & Não & Não & $\begin{array}{l}\text { Busca de poder de polícia para } \\
\text { as GMs deve ser respeitada, } \\
\text { mas sem intervenção e invasão } \\
\text { nas competências das PMs. }\end{array}$ & Sim & \\
\hline & AMEBRASIL & Não & Sim & Não & $N / R$ & Sim & \\
\hline & ANASPRA & Não & Sim & Não & Não & Sim & \\
\hline & FENEME & Não & Não & Não & Não & Sim & \\
\hline \multirow{2}{*}{ 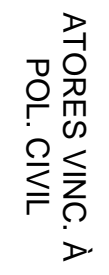 } & ADEPOL & Não & Sim & Não & Sim & Não & \\
\hline & COBRAPOL & $N / R$ & Sim & Não & $\begin{array}{l}\text { Sim. Atribuições de polícia } \\
\text { ostensiva e comunitária } \\
\text { (prevenção). }\end{array}$ & Não & \\
\hline
\end{tabular}




\begin{tabular}{|c|c|c|c|c|c|c|c|}
\hline & ATORES & $\begin{array}{l}\text { Unificação } \\
\text { das polícias }\end{array}$ & $\begin{array}{c}\text { Desvinculação } \\
\text { das PMs do } \\
\text { Exército }\end{array}$ & $\begin{array}{l}\text { Desconstitucio- } \\
\text { nalização do art. } \\
144\end{array}$ & $\begin{array}{c}\text { Ampliação atribuições das } \\
\text { Guardas }\end{array}$ & $\begin{array}{l}\text { Ciclo completo da } \\
\text { atividade policial }\end{array}$ & Outra \\
\hline \multirow{3}{*}{ 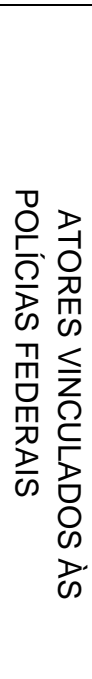 } & FENAPRF & Não & Não & Não & Não & Sim & \\
\hline & ADPF & Não & Sim & Não & $\begin{array}{l}\text { Sim. Assumir parte das atribuições } \\
\text { das PMs nos municípios, em rel. } \\
\text { aos delitos de pequeno potencial } \\
\text { ofensivo, contravenções penais e } \\
\text { ilícitos de natureza administrativa. }\end{array}$ & Não & $\begin{array}{l}\text { Resgate do } \\
\text { reconhecimento } \\
\text { constitucional } \\
\text { do Delegado de } \\
\text { Polícia como } \\
\text { carreira jurídica. }\end{array}$ \\
\hline & FENAPEF & Sim & Sim & Sim & $\begin{array}{l}\text { Sim. Formalizar as ocorrências } \\
\text { através de procedimento } \\
\text { administrativo ágil ou TC, } \\
\text { encaminhando diretamente ao MP, } \\
\text { para judicialização, para resposta } \\
\text { ágil aos anseios da sociedade. }\end{array}$ & Sim & $\begin{array}{c}\text { Carreira única, } \\
\text { com início, meio } \\
\text { e fim, entrando } \\
\text { na base, } \\
\text { podendo, } \\
\text { através da } \\
\text { capacitação, } \\
\text { chegar ao topo. }\end{array}$ \\
\hline \multirow{4}{*}{ 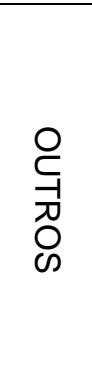 } & FNOP & $\mathrm{N} / \mathrm{R}$ & Sim & Não & "Não temos posição definida." & $\mathrm{N} / \mathrm{R}$ & \\
\hline & $\begin{array}{l}\text { SSP AM }^{* * * *} \\
(\text { CONSESP) }\end{array}$ & Sim & Sim & Não & Sim & $\begin{array}{l}\text { "Ciclo completo para o } \\
\text { TCO." }\end{array}$ & \\
\hline & $\mathrm{ABC}$ & Não & Não & Não & $\mathrm{N} / \mathrm{R}$ & $\begin{array}{l}\text { Sim. } \\
\text { Mas é necessário definir } \\
\text { melhor o que se entende } \\
\text { por ciclo completo. }\end{array}$ & \\
\hline & SINDAPEF & $\mathrm{N} / \mathrm{R}$ & Não & Não & $\begin{array}{l}\text { Sim. Poder de polícia para } \\
\text { pequenos delitos. }\end{array}$ & Sim & \\
\hline
\end{tabular}

* O Fórum Brasileiro de Segurança Pública, segundo o respondente, pela sua natureza, não pode defender propostas políticas e sim fortalecer os canais técnicos de informação capazes de influenciar os responsáveis por ações no campo da segurança pública.

${ }^{* *}$ A pessoa que respondeu ao questionário assinalou que o fez representando o Observatório de Favelas, que compõe a Rede F4.

*** Posicionamento pessoal do Presidente do Conselho Nacional dos Secretários e Gestores Municipais de Segurança Pública, representante da FNP.

**** Posicionamento pessoal do Secretário de Segurança Pública do Amazonas, presidente do CONSESP.

Obs: O termo N/R (não respondeu) foi utilizado nos casos em que o respondente não assinalou nenhuma das alternativas, "sim" ou "não". 


\section{Quadro 7}

\section{Sobre 0 atual modelo de segurança pública}

\begin{tabular}{|c|c|c|c|c|c|c|}
\hline & ATORES & $\begin{array}{c}\text { Não } \\
\text { precisa } \\
\text { ser } \\
\text { alterado }\end{array}$ & $\begin{array}{c}\text { Não precisa } \\
\text { ser alterado, } \\
\text { mas precisa } \\
\text { de mais } \\
\text { investimentos } \\
\text { materiais e } \\
\text { humanos }\end{array}$ & $\begin{array}{c}\text { Não precisa } \\
\text { ser alterado, } \\
\text { mas é } \\
\text { preciso } \\
\text { modernizar } \\
\text { a gestão }\end{array}$ & $\begin{array}{c}\text { Precisa ser } \\
\text { alterado para } \\
\text { incluir novos } \\
\text { atores, como } \\
\text { os municípios, } \\
\text { com mais } \\
\text { prevenção, } \\
\text { participação e } \\
\text { controle }\end{array}$ & $\begin{array}{c}\text { Precisa ser } \\
\text { estrutural/e } \\
\text { reformulado, } \\
\text { criando-se } \\
\text { novo modelo } \\
\text { para as } \\
\text { instituições } \\
\text { policiais }\end{array}$ \\
\hline \multirow{9}{*}{$\begin{array}{l}D \\
1 \\
0 \\
\text { 而 } \\
\infty \\
\infty \\
0 \\
\frac{0}{D} \\
\frac{D}{\omega}\end{array}$} & FENDH & & & & & $x$ \\
\hline & ISPCV & & & & $x$ & \\
\hline & FBSP & & & & & $x$ \\
\hline & $\begin{array}{c}\text { Instituto } \\
\text { Sou da Paz }\end{array}$ & & & & $x$ & \\
\hline & Viva Rio & & & & $x$ & \\
\hline & $\begin{array}{c}\text { Rede } \\
\text { Desarma } \\
\text { Brasil }\end{array}$ & & & & $x$ & \\
\hline & Rede F4 & & & & $x$ & $x$ \\
\hline & $\begin{array}{c}\text { Grande } \\
\text { Oriente do } \\
\text { Brasil }\end{array}$ & & $x$ & $x$ & $x$ & \\
\hline & RENAESP & & & & $x$ & $x$ \\
\hline \multirow{3}{*}{ 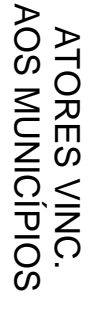 } & FNP & & & & $x$ & \\
\hline & GGI-Ms & & & & $X$ & $x$ \\
\hline & CNGM & & & & $X$ & \\
\hline
\end{tabular}




\begin{tabular}{|c|c|c|c|c|c|c|}
\hline & ATORES & $\begin{array}{c}\text { Não } \\
\text { precisa } \\
\text { ser } \\
\text { alterado }\end{array}$ & $\begin{array}{l}\text { Não precisa } \\
\text { ser alterado, } \\
\text { mas precisa } \\
\text { de mais } \\
\text { investimentos } \\
\text { materiais e } \\
\text { humanos }\end{array}$ & $\begin{array}{c}\text { Não precisa } \\
\text { ser alterado, } \\
\text { mas é } \\
\text { preciso } \\
\text { modernizar } \\
\text { a gestão }\end{array}$ & $\begin{array}{c}\text { Precisa ser } \\
\text { alterado para } \\
\text { incluir novos } \\
\text { atores, como } \\
\text { os municípios, } \\
\text { com mais } \\
\text { prevenção, } \\
\text { participação e } \\
\text { controle }\end{array}$ & $\begin{array}{c}\text { Precisa ser } \\
\text { estrutural/e } \\
\text { reformulado, } \\
\text { criando-se } \\
\text { novo modelo } \\
\text { para as } \\
\text { instituições } \\
\text { policiais }\end{array}$ \\
\hline \multirow{4}{*}{ 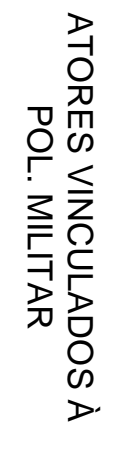 } & CNCG & & & $x$ & & \\
\hline & AMEBRASIL & & $X$ & $x$ & & \\
\hline & ANASPRA & & & $X$ & & \\
\hline & FENEME & & & $x$ & & \\
\hline \multirow{2}{*}{ 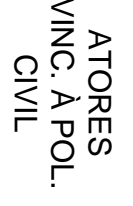 } & ADEPOL & & & & $X$ & \\
\hline & COBRAPOL & & & & $X$ & \\
\hline \multirow{3}{*}{ 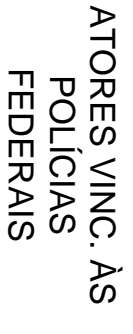 } & FENAPRF & & & & $x$ & \\
\hline & ADPF & & & & $X$ & \\
\hline & FENAPEF & & & & & $x$ \\
\hline \multirow{4}{*}{ 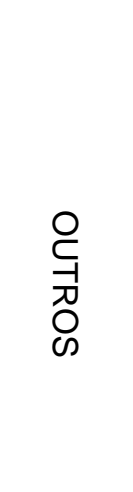 } & FNOP & & & & & $X$ \\
\hline & $\begin{array}{c}\text { SSP - } \\
\text { Amazonas } \\
\text { (CONSESP) }\end{array}$ & & & & $x$ & \\
\hline & $A B C$ & & & & $X$ & \\
\hline & SINDAPEF & & & & & $x$ \\
\hline
\end{tabular}




\section{ANEXO D - RELAÇÃO DE MUNICÍPIOS PRONASCI}

\begin{tabular}{|c|c|c|c|}
\hline Acre & Maranhão & Rio de Janeiro & $\begin{array}{l}\text { Rio Grande do Sul } \\
\text { (cont.) }\end{array}$ \\
\hline Brasiléia & & Rio de Janeiro & Passo Fundo \\
\hline Cruzeiro do Sul & São Luis & Duque de Caxias & Bagé \\
\hline Rio Branco & Minas Gerais & Nova Iguaçu & São Paulo \\
\hline Alagoas & & São Gonçalo & São Paulo \\
\hline Maceió & Belo Horizonte & Belford Roxo & Guarulhos \\
\hline Bahia & Contagem & São João de Meriti & Cotia \\
\hline Salvador & Betim & Niterói & Embu das Artes \\
\hline Camaçari & Ribeirão das Neves & Itaboraí & Embu Guaçu \\
\hline Simões Filho & Santa Luzia & Magé & $\begin{array}{c}\text { Itapecerica da } \\
\text { Serra }\end{array}$ \\
\hline Lauro de Freitas & Ibirité & Mesquita & Itapevi \\
\hline Ceará & Varginha & Nilópolis & Jandira \\
\hline Fortaleza & Uberaba & Queimados & $\begin{array}{c}\text { Pirapora do Bom } \\
\text { Jesus }\end{array}$ \\
\hline Juazeiro do Norte & Pará & Macaé & $\begin{array}{c}\text { Santana de } \\
\text { Parnaíba }\end{array}$ \\
\hline Distrito Federal & Belém & Itaguaí & Taboão da Serra \\
\hline Brasília & Ananindeua & Petrópolis & $\begin{array}{c}\text { Vargem Grande } \\
\text { Paulista }\end{array}$ \\
\hline Espírito Santo & Pernambuco & Teresópolis & Osasco \\
\hline Vitória & Recife & Rio Grande do Sul & Campinas \\
\hline Cariacica & $\begin{array}{l}\text { Jaboatão dos } \\
\text { Guararapes }\end{array}$ & Porto Alegre & Diadema \\
\hline Vila Velha & Olinda & Canoas & $\begin{array}{c}\text { São Bernardo do } \\
\text { Campo }\end{array}$ \\
\hline Viana & $\begin{array}{c}\text { Cabo de Santo } \\
\text { Agostinho }\end{array}$ & Alvorada & Santo André \\
\hline Serra & Paulista & Viamão & Araraquara \\
\hline
\end{tabular}




\begin{tabular}{|c|c|c|c|}
\hline Goiás & $\begin{array}{c}\text { São Lourenço da } \\
\text { Mata }\end{array}$ & Novo Hamburgo & $\begin{array}{c}\text { Ferraz } \\
\text { Vasconcelos }\end{array}$ \\
\hline Luziânia & Caruaru & São Leopoldo & Sorocaba \\
\hline $\begin{array}{c}\text { Águas Lindas de } \\
\text { Goiás }\end{array}$ & Paraná & Gravataí & Jundiaí \\
\hline Novo Gama & Curitiba & Cachoeirinha & Rio Claro \\
\hline Planaltina & $\begin{array}{c}\text { São José dos } \\
\text { Pinhais }\end{array}$ & Esteio & Sergipe \\
\hline $\begin{array}{c}\text { Valparaíso de } \\
\text { Goiás }\end{array}$ & Colombo & Guaíba & Aracaju \\
\hline Formosa & Piraquara & Sapucaia do Sul & $\begin{array}{c}\text { Nossa Senhora do } \\
\text { Socorro }\end{array}$ \\
\hline Cidade Ocidental & $\begin{array}{c}\text { Almirante } \\
\text { Tamandaré }\end{array}$ & Santa Maria & \\
\hline Cristalina & Araucária & Santa Cruz do Sul & \\
\hline Pirenópolis & Foz do Iguaçu & Caxias do Sul & \\
\hline $\begin{array}{l}\text { Aparecida de } \\
\text { Goiânia }\end{array}$ & Pinhais & Vacaria & \\
\hline
\end{tabular}

Fonte: Assessoria de Assuntos Federativos do Ministério da Justiça. Set.09 


\section{ANEXO E - PRINCÍPIOS E DIRETRIZES DEFINIDOS NA 1a. CONSEG}

\section{PRINCÍPIOS:}

1. Ser uma política de Estado que proporcione a autonomia administrativa, financeira, orçamentária e funcional das instituições envolvidas, nos três níveis de governo, com descentralização e integração sistêmica do processo de gestão democrática, transparência na publicidade dos dados e consolidação do Sistema Único de Segurança Pública - SUSP e do Programa Nacional de Segurança Pública com Cidadania - PRONASCI, com percentual mínimo definido em lei e assegurando as reformas necessárias ao modelo vigente. (793 VOTOS)

2. Pautar-se na manutenção da previsão constitucional vigente dos órgãos da área, conforme artigo 144 da Constituição Federal. (455 VOTOS)

3. Ser pautada pela defesa da dignidade da pessoa humana, com valorização e respeito à vida e à cidadania, assegurando atendimento humanizado a todas as pessoas, com respeito às diversas identidades religiosas, culturais, étnico-raciais, geracionais, de gênero, orientação sexual e as das pessoas com deficiência. Deve ainda combater a criminalização da pobreza, da juventude, dos movimentos sociais e seus defensores, valorizando e fortalecendo a cultura da paz. (402 VOTOS)

4. Fomentar, garantir e consolidar uma nova concepção de segurança pública como direito fundamental e promover reformas estruturais no modelo organizacional de suas instituições, nos três níveis de governo, democratizando, priorizando o fortalecimento e a execução do SUSP - Sistema Único de Segurança Pública -, do PRONASCI - Programa Nacional de Segurança Pública com Cidadania - e do CONASP - Conselho Nacional de Segurança Pública com Cidadania (265 VOTOS).

5. Pautar-se pelo reconhecimento jurídico-legal da importância do município como cogestor da área, fortalecendo sua atuação na prevenção social do crime e das violências. (258 votos), 
6. Ser pautada na intersetorialidade, na transversalidade e na integração sistêmica com as políticas sociais, sobretudo na área da educação, como forma de prevenção do sinistro, da violência e da criminalidade, reconhecendo que esses fenômenos têm origem multicausal (causas econômicas, sociais, políticas, culturais, etc.) e que a competência de seu enfrentamento não pode ser de responsabilidade exclusiva dos órgãos de segurança pública. (243 V0TOS)

7. Reconhecer a necessidade de reestruturação do sistema penitenciário, tornando-o mais humanizado e respeitador das identidades, com capacidade efetiva de ressocialização dos apenados, garantindo legitimidade e autonomia na sua gestão, privilegiando formas alternativas à privação da liberdade e incrementando as estruturas de fiscalização e monitoramento. (135 VOTOS)

8. Estar fundamentada no fortalecimento da família, na educação como garantidora da cidadania e de condições essenciais para a prevenção da violência. Deve ser assumida por todos os segmentos da sociedade com vistas ao resgate de valores éticos e emancipatórios. Deve ainda considerar os trabalhadores da área como educadores, enfatizando sua formação humanista. (122 VOTOS).

9. Estabelecer um sistema nacional de conselhos de segurança autônomos, independentes, deliberativos, participativos, tripartites para favorecer o controle social nas três esferas do governo, tendo o Conselho Nacional de Segurança Pública - CONASP como importante instância deliberativa de gestão compartilhada. (112 VOTOS).

10. Estar pautada na valorização do trabalhador da área por meio da garantia de seus direitos e da formação humanista, assegurando seu bem estar físico, mental, familiar, laboral e social. (108 VOTOS)

\section{DIRETRIZES}

1. 6.6 A - Manter no Sistema Prisional um quadro de servidores penitenciários efetivos, sendo específica a eles a sua gestão, observando a proporcionalidade de servidores penitenciários em policiais penais. Para isso: aprovar e implementar a 
Proposta de Emenda Constitucional 308/2004; garantir atendimentos médico, psicológico e social ao servidor; implementar escolas de capacitação. (1095 VOTOS)

2. 4.16 - Promover a autonomia e a modernização dos órgãos periciais criminais, por meio de orçamento próprio, como forma de incrementar sua estruturação, assegurando a produção isenta e qualificada da prova material, bem como o princípio da ampla defesa e do contraditório e o respeito aos direitos humanos. (1.094 VOTOS)

3. 7.7. B - Manter as atribuições constitucionais e a autonomia dos corpos de Bombeiros Militares, definição de piso salarial nacional; formação e capacitação continuada, bem como melhores condições de trabalho com equipamentos adequados. (1013 VOTOS)

4. 2.6 A - Estruturar os órgãos policiais federais e estaduais para que atuem em ciclo completo de polícia, delimitando competências para cada instituição de acordo com a gravidade do delito sem prejuízo de suas atribuições específicas. (868 VOTOS)

5. 1.1 A (+1.3) - Criar, implantar, estruturar, reestruturar em todos os municípios, conselhos municipais de segurança, conselhos comunitários de segurança pública, com poderes consultivo e deliberativo, propositivo e avaliador das Políticas Públicas de Segurança, com representação paritária e proporcional, com dotação orçamentária própria, a fim de garantir a sustentabilidade e condições necessárias para seu efetivo funcionamento e a continuidade de CONSEG como fórum maior de deliberações. Estruturar os GGls (Estadual e Municipal) como forma de integrar a sociedade e o poder executivo, com a composição paritária e proporcional. (799 VOTOS)

6. 3.13. A - Instituir lei orgânica que proteja direitos como um sistema remuneratório nacionalmente unificado, com paridade entre ativos e inativos, aposentadoria especial com proventos integrais, de 25 anos de serviço para mulher e 30 anos para homens, desde que tenham no mínimo 20 anos de efetivo serviço, para profissionais 
de segurança pública, instituindo cota compulsória à inatividade em favorecimento da progressão funcional e que garanta aposentadoria integral. (722 VOTOS)

7. 5.2 C - Desenvolver e estimular uma cultura da prevenção nas políticas públicas de segurança, através da implementação e institucionalização de programas de policiamento comunitário, com foco em três aspectos: um, dentro das instituições de segurança, com estudos, pesquisas, planejamento, sistemas de fiscalização e policiamento preventivo, transparência nas ações policiais, bem como a própria reeducação e formação das forças policiais; reduzindo a postura militarizada; dois, com programas educativos de prevenção dentro das escolas, famílias, movimentos sociais e culturais e a comunidade como um todo; três, apoiados no desenvolvimento de redes sociais e intersetoriais para a criação de uma ampla rede de prevenção e segurança. (707 VOTOS)

8. 2.18 B - Regulamentar as Guardas Municipais como polícias municipais: definir suas atribuições constitucionais; regulamentar a categoria; garantir direitos estatutários, dentre eles jornada de trabalho, plano de carreira, aposentadoria, assistência física e mental, regime prisional diferenciado, programas habitacionais, seguro de vida, critérios do exame psicotécnico a cada quatro anos, concurso público, com exigência mínima de nível médio completo. (697 VOTOS)

9. $5.30 \mathrm{~A}$ - Criar mecanismos de combate e prevenção a todas as formas de preconceitos e discriminações e a impunidade de crimes por motivações preconceituosas, com os recortes em pessoas com deficiência, geracional, étnicoracial, orientação sexual e identidade de gênero. (668 VOTOS)

10. 7.1. A - Inserir no currículo e no calendário escolar em todos os sistemas de ensino: Semana de Prevenção a sinistros; aulas de primeiros socorros; temas afetos à Defesa Civil, à Educação para o Trânsito, à pessoa com deficiência, à Educação Ambiental e à Segurança pública. (580 VOTOS) 
11. 1.8 A - Definir e regulamentar o papel e as atribuições constitucionais dos municípios no tocante à Segurança Pública. (514 VOTOS)

12. 2.19 A - Realizar a transição da segurança pública para atividade eminentemente civil; desmilitarizar as polícias; desvincular a polícia e corpos de bombeiros das forças armadas; rever regulamentos e procedimentos disciplinares; garantir livre associação sindical, direito de greve e filiação político-partidária; criar código de ética único, respeitando a hierarquia, a disciplina e os direitos humanos; submeter irregularidades dos profissionais militares à justiça comum. (508 VOTOS)

13. 7.17. A - Incluir os Corpos de Bombeiros Militares dos Estados e do Distrito Federal no Plano Nacional de Segurança Pública, bem como: criar Comissões Municipais de prevenção de acidentes e desastres custeadas pelo governo federal, criar uma Secretaria Executiva de Defesa Civil, e garantir a coordenação da Defesa Civil sob responsabilidade dos Corpos de Bombeiros. (507 VOTOS)

14. 3.1. A - Criar planos de carreira com piso salarial digno, justo e igualitário, para os profissionais de segurança pública, nas três esferas governamentais, com reajuste periódico, visando à garantia da dedicação integral e exclusiva desses profissionais ao serviço de segurança pública. (482 VOTOS)

15. 2.6. C - Rechaço absoluto à proposta de criação do Ciclo Completo de Polícia. (446 VOTOS)

16. 4.23. A - Modernizar o inquérito policial num mecanismo ágil de investigação, de maneira a estipular instrumentos legislativos, diminuindo seu caráter essencialmente cartorial, prevalecendo a sua natureza jurídico-técnico-científica para a produção de provas com maior sustentabilidade no processo penal, e de tempo razoável para a duração do inquérito e do processo, privilegiando a eficiência, a resposta oportuna à sociedade e combatendo a morosidade. (427 VOTOS)

17. $6.2 \mathrm{~A}$ - Garantir o acesso à justiça e assistência jurídica gratuita àqueles em conflito com a lei, por intermédio da implementação e fortalecimento das defensorias 
públicas, assegurando maior celeridade aos processos e aos benefícios da Lei de Execução Penal. (339 VOTOS)

18. 3.2. A - Criar e implantar carreira única para os profissionais de segurança pública, desmilitarizada com formação acadêmica superior e especialização com plano de cargos e salários em nível nacional, efetivando a progressão vertical e horizontal na carreira funcional. (331 VOTOS)

19. 7.6. A - Criar mecanismos legais que garantam recursos orçamentários e financeiros mínimos e proporcionais para adoção de políticas públicas na área de prevenção de acidentes. (313 VOTOS)

20. 1.13 A - Reestruturar o Conselho Nacional de Segurança Pública e reformular os Conselhos estaduais e municipais, considerando os princípios de democracia, representatividade, paridade, autonomia, transparência, e tendo como foco principal o combate à corrupção, a prestação de serviços de qualidade à população e a articulação permanente com as forças sociais. Para isso: eleger seus membros bienalmente, por meio de conferências e fóruns nos quais haja plena participação social; adequar suas ações às realidades locais e regionais, operando os instrumentos democráticos de controle com monitoramento de dados quantitativos e qualitativos das situações de violência e ocorrências criminais; trabalhar em ações de caráter consultivo, propositivo, fiscalizatório e deliberativo, adequando suas resoluções às orientações e regulamentações do Ministério da Justiça; manter estreita relação com todos os conselhos da área de segurança e outros, de modo a facilitar a articulação de ações; gerir todos os seus recursos participativamente, cuidando para que sejam efetivamente utilizados no alcance de seus objetivos. Elaborar e aprimorar a estrutura político-administrativa do Conselho Nacional de Segurança Pública em harmonia legal com os conselhos estaduais e municipais de segurança, considerando os princípios de democracia, representatividade, paridade, autonomia e transparência, focado no combate à corrupção e na qualidade de prestação de serviço a população. (305 VOTOS) 
21. 3.20.B - Revisar, atualizar e democratizar os regulamentos e procedimentos disciplinares militares, conforme o artigo $5^{\circ}$ da Constituição Federal. (304 VOTOS)

22. $6.52 \mathrm{~A}$ - Priorizar na agenda política, administrativa e financeira dos governos para a estruturação de um Sistema Nacional de Penas e Medidas Alternativas, criando estruturas e mecanismos nos Estados e o Distrito Federal, no âmbito do Executivo, estruturando e aparelhando os órgãos da Justiça Criminal e priorizando as penas e medidas alternativas, a justiça restaurativa e a mediação de conflitos. (293 VOTOS)

23. 1.9. A - Criar, estruturar, implantar, compor, e fortalecer, democraticamente, Gabinetes de Gestão Integrada nos três níveis de governo, para: promover a atuação conjunta e coordenada dos organismos de segurança pública com entidades públicas e privadas, respeitando e acatando as diretrizes e deliberações dos conselhos de segurança pública. (283 VOTOS)

24. 4.4 A (+4.14) - Fortalecer e utilizar as Unidades de Inteligência Policial como base para o desenvolvimento de ações direcionadas a alvos específicos, visando a reduzir o impacto negativo da ação policial repressiva na comunidade como um todo. Investir nas áreas de inteligência e tecnologia de combate às organizações criminosas. Aperfeiçoar e integrar a rede de captação, circulação, processamento e disseminação de informações e conhecimento de inteligência de segurança pública, além de promover intercâmbio nacional e internacional com outros órgãos de inteligência, aperfeiçoando o sistema judicial. (254 VOTOS)

25. 6.17 - Definir diretrizes norteadoras para a gestão democrática do sistema prisional, estabelecendo normas nacionais, com fortalecimento, reforma, oficialização e incentivo à criação de Conselhos Penitenciários Federal, Estadual e Municipais como instância deliberativa e órgão de fiscalização, de ouvidorias e de corregedorias do sistema, com ampla composição e participação, com incumbência de fomentar a gestão compartilhada, facilitar o controle social através de mecanismos autônomos e paritários. (245 VOTOS) 
26. 3.3. A - Instituir políticas de valorização, qualidade de vida, apoio biopsicossocial, ético e profissional dos trabalhadores da área de Segurança Pública. (228 VOTOS)

27. 4.13.B (+4.24) - Instituir, construir e aumentar o número de delegacias especializadas e distritais com atendimento a grupos vulneráveis e especiais, com profissionais especialistas em crimes de intolerância social, capazes de desenvolver ações de sensibilização e capacitação continuada dos policiais para atendimento e acolhimento de vitimas, garantindo a elas e seus familiares todos os seus direitos, bem como a eficiência no programa de proteção a testemunhas e denunciantes. Para isso, se necessário, fortalecer abrigos, ações e programas de proteção a vítimas, garantindo: a implantação de comitês gestores em nível estadual e municipal de monitoramento do pacto de enfrentamento à violência contra as mulheres; a implantação das Delegacias Legais e Delegacias da Mulher nos municípios ainda não contemplados e unidades de perícia técnico-científica; realização de plantões de atendimento durante o final de semana e feriados; promoção de programas para a erradicação da intolerância e da violência de gênero, da pessoa idosa, de crimes raciais, e contra GLBT. (220 VOTOS)

28. 1.29. B - Implantar, manter e aprimorar o Programa Nacional de Segurança Pública com a Cidadania (Pronasci) em todos os espaços do território nacional como política permanente de Estado. (213 VOTOS)

29. 3.19. A - Prover os servidores da segurança pública das prerrogativas constitucionais dos integrantes do Ministério Público e do Poder Judiciário. (206 VOTOS)

30. 6.39 - Desvincular totalmente a custódia de presos, tanto provisórios como condenados, das secretarias de segurança pública conforme as recomendações internacionais. (205 VOTOS)

31. 4.9. A - Promover políticas que estimulem a construção de redes de atendimento intermultidisciplinar para grupos vulneráveis com unidades especializadas dos 
Órgãos de segurança pública e do sistema de justiça, com equipamentos adequados e profissionais em quantidade suficiente, dentro da filosofia do policiamento comunitário, respeitando a heterogeneidade dos diversos grupos sociais, evitando abusos e intensificando o combate ao trabalho escravo, ao tráfico de seres humanos, à exploração sexual de crianças e jovens, à homofobia, ao racismo e à violência familiar. (205 VOTOS)

32. 7.2. A - Estruturar e ampliar a rede do Sistema de Prevenção, Atendimentos emergenciais e acidentes em todos os municípios do Brasil, priorizando os serviços aos municípios onde seja reconhecido o risco de acidentes ou desastre. (203 VOTOS)

33. $5.41 \mathrm{~A}$ - Manter a maioridade penal em 18 anos e o tempo de cumprimento de medidas sócio-educativas de acordo com a legislação vigente. (200 VOTOS)

34. 4.6. B - Implementar uma Política Nacional de Combate ao Crime Organizado para intensificar, ampliar e realizar ações policiais qualificadas, criar sistema de bloqueio de celulares e rádios em presídios como medida de soberania e proteção a toda a população, com vistas à redução da violência e criminalidade, e ao combate estratégico do crime organizado de todos os tipos. Para isto, se necessário, deve-se: identificar o ciclo criminal de cada região, reforçar o policiamento rodoviário e instalar postos policiais nas rotas do tráfico; criar unidades especializadas integradas às unidades de inteligência para atuarem em centros urbanos e rurais, rodovias, portos, aeroportos e fronteiras; envolver o Poder Judiciário, Ministério Público, Polícias e outros órgãos nas ações; modernizar o ordenamento jurídico; criar Varas Criminais Especiais para o Crime Organizado; acabar com a estrutura prisional criminalizatória e promover punições severas. (199 VOTOS)

35. 6.7. B - Melhorar os serviços de saúde dos reclusos e profissionais, atendendo às especificidades de idade e gênero. Implantação do programa de saúde da família com profissionais de todas as áreas, em número suficiente. Fornecer alimentação adequada. Construir hospitais penitenciários em todos os estados. Considerar os 
princípios de reforma psiquiátrica. Criação de CAPS para tratamento dos dependentes de álcool, drogas e pessoas com sofrimento mental, com participação familiar. (194 VOTOS)

36. 5.42. A - Fortalecer a Defensoria Pública, com a sua estruturação em todas as comarcas do país, como instrumento viabilizador do acesso universal à justiça e à defesa técnica, bem como criar os juizados especiais em âmbito nacional e ampliar a efetivação dos já existentes, como forma de aperfeiçoar a prestação jurisdicional. (187 VOTOS)

37. 5.28. A - Reafirmar e cumprir o Estatuto do Desarmamento como política de Estado, observando a efetivação dos convênios com os Estados-Membros para o recolhimento voluntário de armas, o fortalecimento da fiscalização do uso de armas pelo SENARM (Serviço Nacional de Registro de Armas) e a integração dos sistemas de cadastro de armas. (179 VOTOS)

38. 1.2. A - Criar, reformular e estruturar, o funcionamento dos Conselhos de Segurança Pública nos três níveis governamentais, assim como os Conselhos Comunitários, sendo espaços deliberativos da Política de Segurança Pública, de forma paritária e proporcional (Sociedade Civil, Gestores e Trabalhadores) integrando-os aos Gabinetes de Gestão Integrada (GGI). (177 VOTOS)

39. 5.9. C - Instituir programas de prevenção primária da violência, com foco nas áreas de: trânsito, saúde, educação, cultura, lazer, esporte, assistência social e urbanismo para a intersetorialidade das políticas de segurança pública e incentivando a adoção da filosofia de policiamento comunitário. (170 VOTOS)

40. 4.22. A - Tipificações específicas de crimes cometidos contra profissionais de segurança e operadores do direito no exercício ou não da função, e contra seus familiares, com a revisão das leis penais e processuais e segurança transformando esses crimes em hediondos. (170 VOTOS)

Fonte: <http://www.conseg.gov.br/index.php?option=com_content\&view=article\&id=1554:10-consegdefine-qprincipiosq-e-qdiretrizesq-para-seguranca-publica \&catid=49:noticias-gerais $\&$ Itemid=226> . 